\title{
Fistes of AUSTRALIA.
}

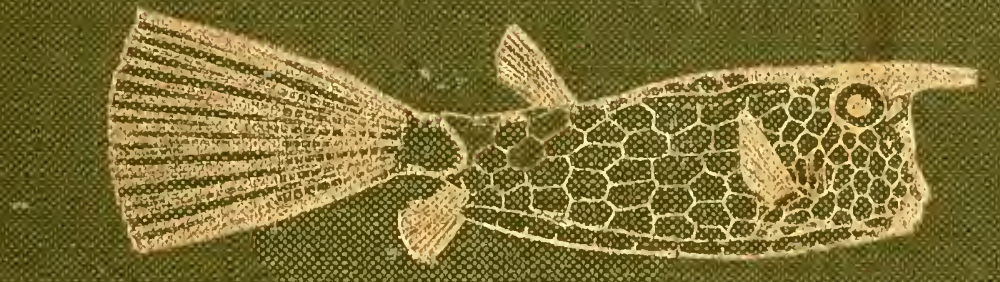



N. Y AORDEMY

OF BCIENCES

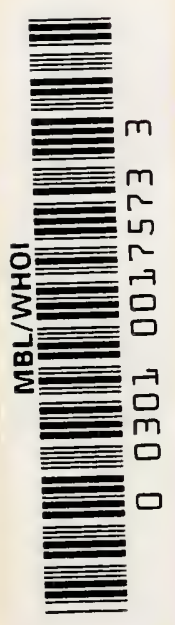






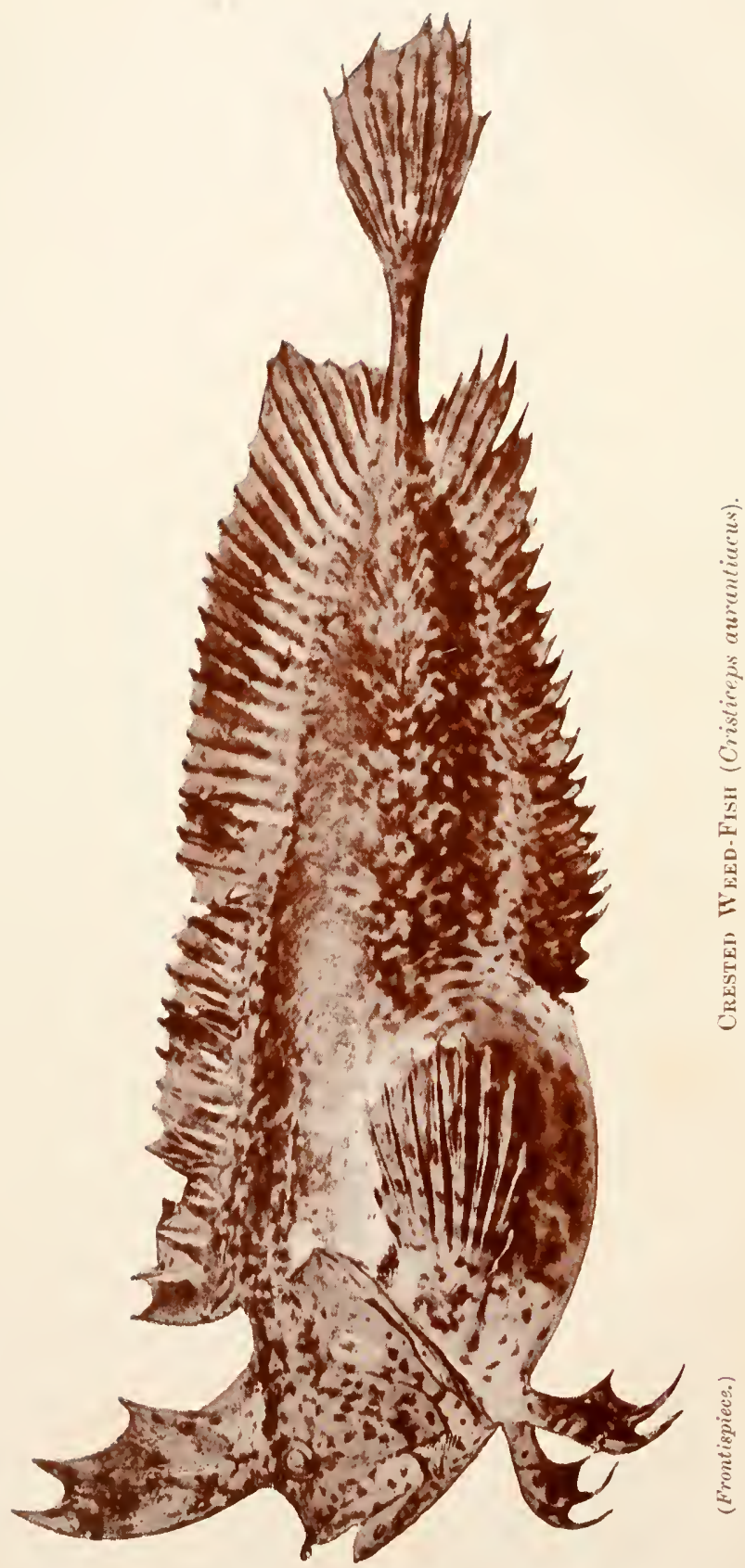


N. Y AconemY

OF BCIENCES

\section{Fishes of Australia:}

A POPUIAR AND SISTEMATIC GUIDE TO THE STUDY OF THE WEALTH IVITHIN OUR IVATERS.

\section{By DaYid G. Stead,}

Naturalist to the boarn of Fisheries for New Solth Wales.

With Ten Full-page Plates and Eighty-eight Illustrations in the Text. 
${ }^{6} 7.1122 . \tan .23$

42203 


\section{PREFACE.}

Australia possesses a rich and varied fish-famina. Of over twelve-thousand species of fishes at present known, about one-tenth have been recorded from the waters of Australia. As the exploration of our waters has but just begun, it is reasonable to suppose that in the near future, the number of fishes known to inhabit them will be greatly augmented.

Amongst our indigenous fishes are many which are of immense importance from an economic point of view, while there are others which are of the greatest interest to the lover of Nature-some because of their intrinsic beauty or remarkable habits, others because of the admirable way in which they have been adapted either in colour or form to their surroundings, and others again because of their intimate connections with fossil fishes of a fardistant geological age.

Viewed from the economic standpoint alone, it may be stated that the fishes of Australia are destined shortly to play an exceedingly important part in contributing to the material wealth of our country.

In the following pages, an attempt has been made by the author, to place before the reader as comprehensive a view of our vast fish-fauna as is possible within the space at our disposal. And here 1 must point out that a complete list of the whole of the known fishes inhabiting the waters of Australia is not-for what are, perhaps, obvious reasons-included within the scope of this volume. Had such been attempted, my present aim must have been entirely defeated; as the work would-of necessity-have been exceedingly bulky (and correspondingly costly), and, under the circumstances, unnecessarily technical. 
While the book is intended to be a "popular work" in the fullest sense of the term, much of the information herein-offered, will be found to be entirely new: while of that which is not altogether so. a large amount is placed before Australian readers for the first time. Though it is intenderl and hoped that it will subserve all the functions of a truly popular work, at the same time, the subject has been treated of in a properly systematic manner from an ichthyological point of view. Thus, the general reader will, when satisfying a natural curiosity, be enabled to learn, without trouble, something of the classification of our fishes; while to the student of zoology, its value will be quite apparent. Each family of Australian fishes has been dealt with in its proper ichthyological sequence; the most important examples economically, or-if none is of importance-the most striking. being touched "pon. In most cases, brief descriptions are given, or the salient features are dwelt upon, so as to assist the reader in identifying the fishes for himself, should they be met with. In this connection, the reacler will be greatly helped by the numerous illustrations to be, found interspersed throughout the book.

The information contained in the introductory portion (Chap. I.) should enable the general reader to uncierstand most technical descriptions of fishes, such as appear in the great works of reference, while for ready reference I have included an Appendix, showing at a glance the principal edible fishes of Australia, with also the States in the waters of which they chiefly abound. The attention of students is directed to the Table of Classification of Australian Fishes appearing at the end of Chapter I., and those who specially interest themselves in the advance and welfare of our country, may find the chapter on Fish Economics of some value. It will certainly help to show what is not done in the utilisation of our marine commercial products. 
In regard to the illustr: tions, which have been reproduced in such an excellent manner by the publishers, I may mention that these have been drawn from various sources. The Frontispiece, all of the life-like full-page plates excepting Plate IX., and the illustration of the Goblin-Fish (Fig. 68), have been reproduced by means of photography, directly from the fishes themselves; the latter having been previously specially preserved by me to enable this to be successfully carried out. The original fishes are included in the working-collection of the Board of Fisheries for New South Wales, and it is duc to the kindness of that body of gentlemen that I am enabled to present these splendid likenesses to the people. A number of the figures in the text (including those of the scales) are from my own pen, while among others I have to acknowledge the works of such renowned ichthyologists as Günther, Day, and Jordan and Evermann. I have likewise to tender my sincere thanks to my honored friend Dr. James C. Cox, M.D., F.R.C.S.E., for the loan of several useful, and hitherto umpublished, drawings.

It is hoped that this work may pave the way for the production of a complete popular and systematic illustrated catalogue of Australian Fishes; this being recognised as of the utmost necessity and undoubtedly of the highest educational importance. The present volume would not be superseded by such a work, but would act as a kind of introduction or handbook to it.

That this may be the means of turning more attention to the vast neglected resources lying in the waters encircling our Island-Continent is my earnest wish.

Department of Fisheries, DAVID G. S'TEAD.

New South Wales, I I th August, Igo6. 



\title{
CONTENTS.
}

\author{
CHAPTER I.
}

INTRODUCTION.

General definition of Fishes-The principal parts of a Fish - The Teeth-The Air-13ladder-The Eyes-The Tongue-The Skeleton-The Fins-The Scales-The Lateral-Line-Barbels -Colouration-Breeding Habits and Eggs-Australian Fishes producing Pelagic Eggs-The Classification of Fishes-Table of

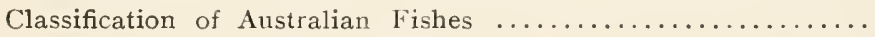

\section{CHAPTER II.}

The Giant Herrings-The Osteoglossids-The Dorab-The Herring Family-The Salmon Family-The AlepocephaloidsStomiatoid Fishes-The Beaked Salmon-The Carp Family-The Catfish Family

\section{CHAPTER III.}

The Little Shore-Eels-The True Eels-The Australian Minnows-The "Grayling" Family-The Scopeloids-The LancetFishes-Notacanthoid Fishes-The Fierasferoids-Flute-Mouths or Tobacco-Pipe Fishes-Bellows-Fishes or Sea-Snipes-Sea-

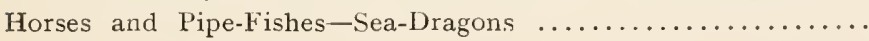

\section{CHAPTER IV.}

Long-Toms, Garfishes and Flying-Fishes-The Hardyhead Family-the Mullet Fanily-Threadfins or Tassel-Fishes-The

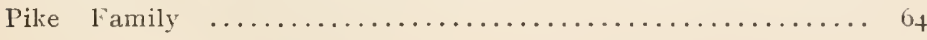

\section{CHAPTER V.}

Cuvier's square-Tail-The Whario Family-The Grenadiers or Whiptails-The Cod Family-The Nannygai Family-Knight Fishes-Bull's-eyes-Centrarchoid Fishes-The Blackfish Family -The Triple-tails-Rifle-l ishes--The Perch Family ......... \& \& $_{t}$ 
viii.

\section{CHAPTER VI.}

The Pseudochromids-The Band-Fishes-The Knife-jawed Page. Fishes-The Whiting Family-The Jewfish Family-The Silverbellies-The Trumpeters-The Morwong Family-Grunters and Boar-Fishes-The Bram Family-Red Mullets or Goat-Fishes .. 108

\section{CHAP'TER VII.}

The Sweep Family-The Coral-Fishes-The SurgeonFishes-The "Black Trevally" Family-The Pomacentrids-The Parrot-Fishes or Wrasses ..................... 33

CHAPTER VIII.

The Yellowtail Family-The Sergeant-Fishes-The Mackerel Family-The Barracouta Family ................... 149

CHAPTER IX.

Swordfishes or Spearfishes-The Luvarus Fish-DolphinFishes-The Pomfrets-The John Dory Family-The Flat-Fishes -The Goby Family ............................ 169

\section{CITAPTER X.}

The Sucking-Fishes-Scorpænoid Fishes-The Flatheads -Gurnards or Gurnets--Flying Gurnards or Sea-Robins-Leptoscopoid Fishes--Notothenioid Fishes-The Star-gazers-Trichono-

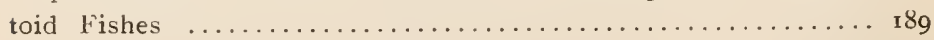

CHAPTER NI.

The Dragonets or Skulpins-The Cling-Fishes-The Blennies -The Frog-Fishes-Zoarcoid Fishes-The Australian Rockling -Ribbon-Fishes-Angler-Fishes or Fishing-Frogs-The Leatherjackets or Filefishes-Box-Fishes or Trunk-Fishes-The loadFishes-Sea-Forcupines-The Sun-Fishes-Lung-Fishes ....... 208 
CHAPTER XII.

Sharks and Rays-Lampreys and Hag-Fishes-The Lampreys -The Lancelets ...............................

Page.

\section{CHAPTER XIII.}

Fishing Nets of New South Wales.-Hauling-Net, GarfishNet, Meshing-Net, Gill-Net, Trammel-Net, Drum-Net, Trawl-Nets.

Fish Economics.-Fish Oil, Fish Fertilizer, Skins of Fishes, Scales of Fishes, Guanin.-Food Value of Australian Fishes

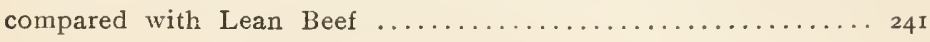

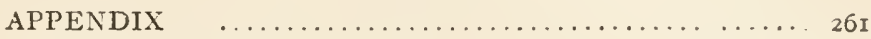

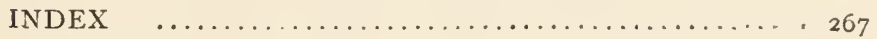




\section{LIST OF ILLUSTR ATIONS.}

\section{PLATES.}

Frontispiece. CRESTED WEED-FISH (Cristiceps aurantiacus)

Facing

Page.

I. Freshwater Catfish (Copidoglanis tandanus) $\ldots \ldots \ldots \ldots 40$

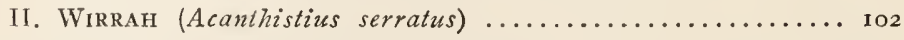

III. KeI.P-FisH (Chironemus marmoratus) $\ldots \ldots \ldots \ldots \ldots \ldots \ldots$ II 8

IV. Silver Perch (Terapon ellipticus) $\ldots \ldots \ldots \ldots \ldots \ldots \ldots \ldots$ I 22

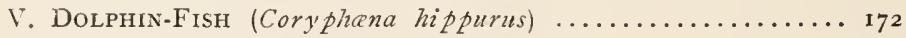

VI. Black Sole $($ Synaptura nigra $\ldots \ldots \ldots \ldots \ldots \ldots \ldots \ldots \ldots \ldots \ldots \ldots \ldots \ldots \ldots \ldots$

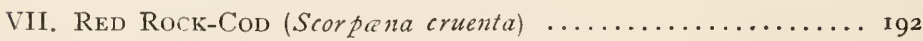

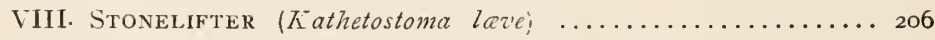

IX. Hair-tailed Blenny (Tiphasia setifer) $\ldots \ldots \ldots \ldots \ldots \ldots$ 2I 2

Fig.

\section{FIGURES IN THE TEXT.}

I. Estuary Perch (Percalates colonsrum) ................ 3

2. Dorsal Fins of Australian Fishes ................. 7

3. Caudal Fins of Australian Fishes ................. 8

4. Types of Cycloid Scales ..................... I I

5. Types of Ctenoid or Comb-like Scales $\ldots \ldots \ldots \ldots \ldots \ldots \ldots$ I 2

6. Snouts of Australian Fishes ..................... 13

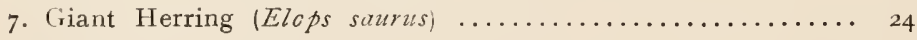

8. Barramundi (Scleropages leichhardti) ............... 26

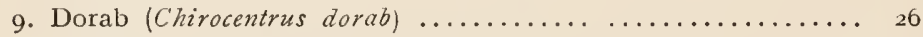

10. Pilchard (Clupanodon neopilchardus) $\ldots \ldots \ldots \ldots \ldots \ldots \ldots \ldots . \ldots \ldots$

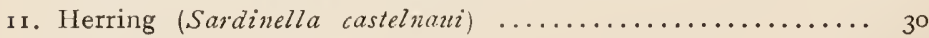

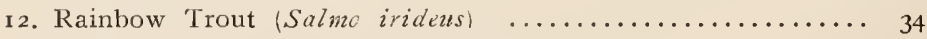

13. Beaked Salmon (Gonorhynchus gonorhynchus) $\ldots \ldots \ldots \ldots \ldots . . \ldots 37$

14. Forepart of Salmon-Catfish (Galeichthys australis) $\ldots \ldots \ldots .44^{2}$

15. Common Eel (Anguilla reinhardtii) ................. 45

16. Tasmanian Minnow (Galaxias truttaceus) $\ldots \ldots \ldots \ldots \ldots \ldots . \ldots 49$

I7. Australian Grayling (Prototroctes marana; ................ $5^{2}$

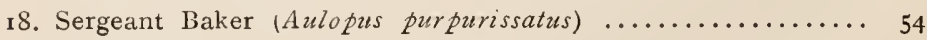

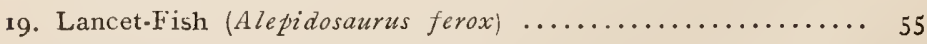

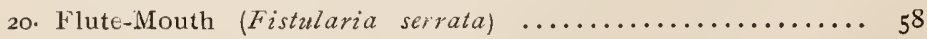

21. Little Bellows-Fish (C'entriscus gracilis) $\ldots \ldots \ldots \ldots \ldots \ldots \ldots . \ldots \ldots$ 
Fig.

Page.

22. Leafy Sea-Horse (Phyllopteryx foliatus) ................ 6r

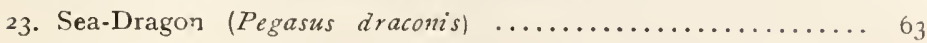

24. Stout Long-Tom (Tylosurus macleayana) $\ldots \ldots \ldots \ldots \ldots \ldots .65$

25. Sea Garfish (Hemirhamphus intermedius) $\ldots \ldots \ldots \ldots \ldots \ldots 66$

26. Short-beaked Garfish (Arrhamphus sclerolepis) ........... 69

27. Sea Mullet (Mugil-dobula) ....................... 74

28. Flat-tail Mullet (Mugil peronii) ................. 78

29. Cooktown "Salmon" (Polynemus tetradactylus) ........... $\delta_{\mathbf{I}}$

3o. Short-finned Pike (Sphyrana nova-hollandia) ............ $\mathrm{S}_{2}$

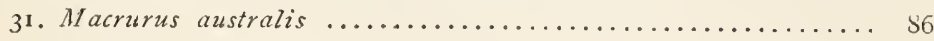

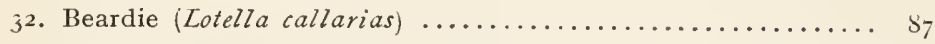

33. Nannygai (Beryx affinis) $\ldots \ldots \ldots \ldots \ldots \ldots \ldots \ldots \ldots \ldots \ldots . \ldots \ldots$

34. Knight-Fish (Monocentris japonicus) ................. 89

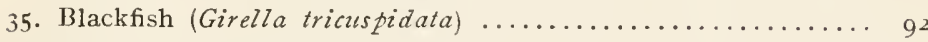

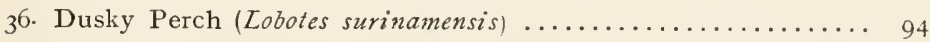

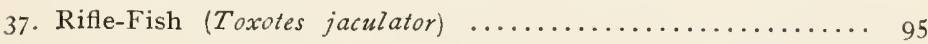

38. Murray Cod (Olngorus macquariensis) .............. 99

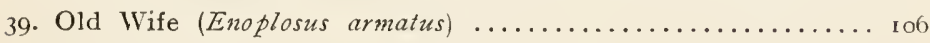

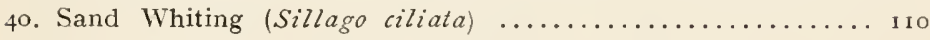

41. Trumpeter Whiting (Sillago maculata) ............... II I

42. Jewfish (Sciana antarctica) ...................... I 5

43. Sea-Carp or Red Morwong (Cheilodactylus fuscus) ........ I 20

44. Head of Richardson's Boar-Fish (IIistiopterus recurvirostris) .. I 24

45. Snapper (Fagrosomus auratus) $\ldots \ldots \ldots \ldots \ldots \ldots \ldots \ldots \ldots \ldots \ldots \ldots \ldots \ldots \ldots \ldots$

46. "Old Man" Snapper (Pagrosomus auratus) ............. I 27

47. Black Bream (Chrysophrys australis) .............. I 28

48. Bar-tailed Goatfish (Upeneus tragula) ................ $3_{2}$

49. Batfish (Moniodactylus argenteuts) ................. 134

50. Spotted Butter-Fish (Ephippus argus) $\ldots \ldots \ldots \ldots \ldots \ldots \ldots$ I 36

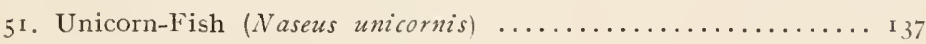

52. "Black Trevally" (Siganus javus) ................. I 39

53. Amphiprion (Amphiprion percula) .................. 1 40

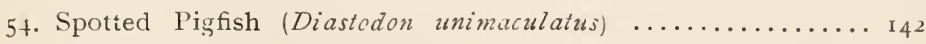

55. Groper (Acherodus gouldii) $\ldots \ldots \ldots \ldots \ldots \ldots \ldots \ldots \ldots \ldots \ldots \ldots \ldots \ldots \ldots \ldots$

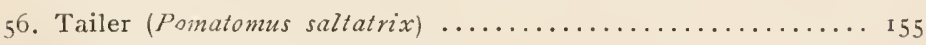

57. Pennant-Fish (Alectis ciliaris) $\ldots \ldots \ldots \ldots \ldots \ldots \ldots \ldots \ldots \ldots \ldots \ldots$

58. Sergeant-Fish (Rachycentron canadus) ................ I59

59. Horse-Mackerel (Sarda chilensis) ................... 164

6o. Barracouta $($ Thyrsites atz $n) \ldots \ldots \ldots \ldots \ldots \ldots \ldots \ldots \ldots \ldots \ldots \ldots \ldots \ldots \ldots$ 
Fig.

61. Spearfish or Swordfish (Tetrapiurus indicus) $\ldots \ldots \ldots \ldots \ldots$ 170

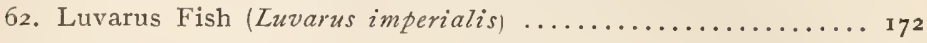

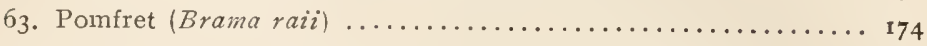

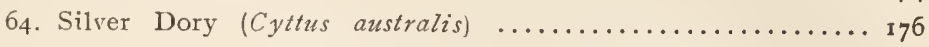

65. Small-toothed Flounder (Paralichthys nova-cambria) ...... I80

66. Striped Gudgeon (Krefftius australis) $\ldots \ldots \ldots \ldots \ldots \ldots \ldots \ldots$

67. Short Sucling-Fish (Remora remora) ................ I90

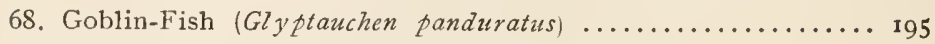

69. Dusky Flathead (Flatycephalus fuscus) $\ldots \ldots \ldots \ldots \ldots \ldots \ldots . \ldots 197$

70. Sharp-beaked Gurnard (Pterygotrigla polyommata) ........ 201

71. Flying Gurnards (Cephalacanthus spinarella) ........... 203

72. Leptoscopus (Leptoscopus macropygus) ................ 204

73. Mottled Dragonet (Callionymus calauropomus) Female ....... 208

74. River Blackfish (Gadopsis marmoratus $) \ldots \ldots \ldots \ldots \ldots \ldots \ldots . \ldots 2$ I I

75. Australian Rockling (Genypterus blacodes) ............ 216

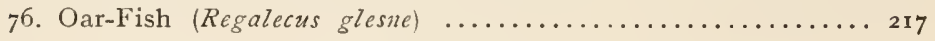

77. Angler-Fish (Antennarius nummifer) $\ldots \ldots \ldots \ldots \ldots \ldots \ldots \ldots \ldots$

78. Orange-spotted Leatherjacket (Monacanthus hippocrepis) .....222

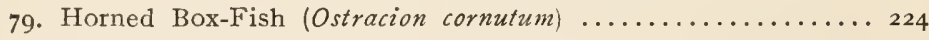

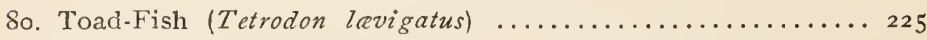

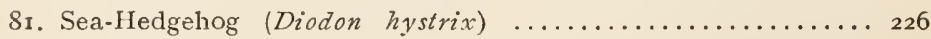

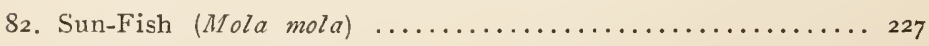

83. Australian Lung-Fish (Neoceratodus forsteri) ........... 229

84. Teeth of Port Jackson Shark (Heterodontus philippi) ...... 234

85. Short-headed Lamprey (Mordacia mordax) ............ 239

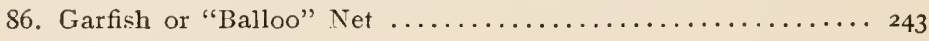

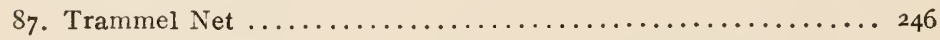

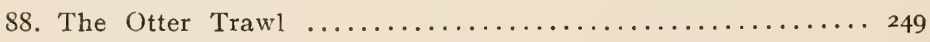




\section{FISHES OF AUSTRALIA.}

Chapter I.

\section{INTRODUCTION.}

General definition of Fishes-The principal parts of a Fish-The Teeth-The Air-Bladder-The Eyes-The Tongue-The Skeleton - The Fins-The Scales-The Lateral-Line-Barbels-Colouration - Breeding Habits and Eggs-Australian Fishes producing Pelagic Eggs-The Classification of Fishes-Table of Classification of Australian Fishes.

Fisiies, defined in a popular way, are aquatic, vertebrated or backboned animals; cold-blooded and breathing by means of gills. They are provided with fins, to assist them in guiding or propelling themselves through the watery element by which they are surrounded, and in which their whole existence is passed. "It is in their conditions of living," writes Bashford Dean, "that they have differed widely from the remaining groups of vertebrates. Aquatic life has stamped them in a common mould, and has prescribed the laws which direct and limit their evolution; it has compressed their head, trunk, and tail into a spindle-like form: it has given them an easy and rapid motion, enabling them to cleave the water like a rounded wedge. It has made their mode of movement, one of undulation : causing the sides of the fish to contract rhythmically, thrusting the animal forward."

In the body of a fish, four parts are nsually distinguished: the head, the trunk, the tail and the fins. The head is ustually divided from the trunk, by the gill- 
opening; while the tail is generally said to begin at the vent. There are numerous exceptions to the latter, however, particularly among the "flat-fishes" of the family Pleuronectide, such as our Soles and Flounders, in which the vent is situated far forward and near to the head.

If one examines a fish, he will find at the back of the head, on each side, a kind of moveable flap covering the gills. This is the gill-cover or opercle, which is composed of three bony plates, styled the opercle, the $s u b$ opercle and the inter-opercle; the modifications of which, are sometimes of considerable value in determining the natural affinities of fishes. In some groups, such as the Eels and the Dragonets, the opercle is so entirely covered by the skin, as not to be visible, excepting after dissection; while in the cartilaginous fishes (Sharks, Ray's, \&c.) it is entirely absent.

The gills, or, as they are termed, the branchica, are fine hair-like or leaf-like projections, filled with innumer-able bloodvessels, and usually supported on the outer curves of cartilaginous or bony arches, known as gillarches. In the true fishes, the normal number of gills on each side is four.* Along the inner edges of the gillarches, are often to be found, hard, bony appendages or projections, which are subject to great variation in different species. These are known as the gill-rakers. The gill-membranes are those which usually serve to attach the gill-covers to the isthmus, which is that thick, fleshy projection between the gill openings. Occasionally are to be found on the inner side of the opercle, near its junction with the preopercle, small or imperfectlydeveloped gills, which are known as pseudobranchice. In the process of breathing, the water is constantly taken in by the mouth and passed out again between the gills; in its passage aërating the blood, as it circulates through the gill-filaments. This is the habit which has given rise to the saying, "drink like a fish," which, of course, has no foundation, as the fish does not really drink the water.

* Sharks and Rays have usually five, and occasionally (in the case of the "One-finned" Sharks) even six or seven. 

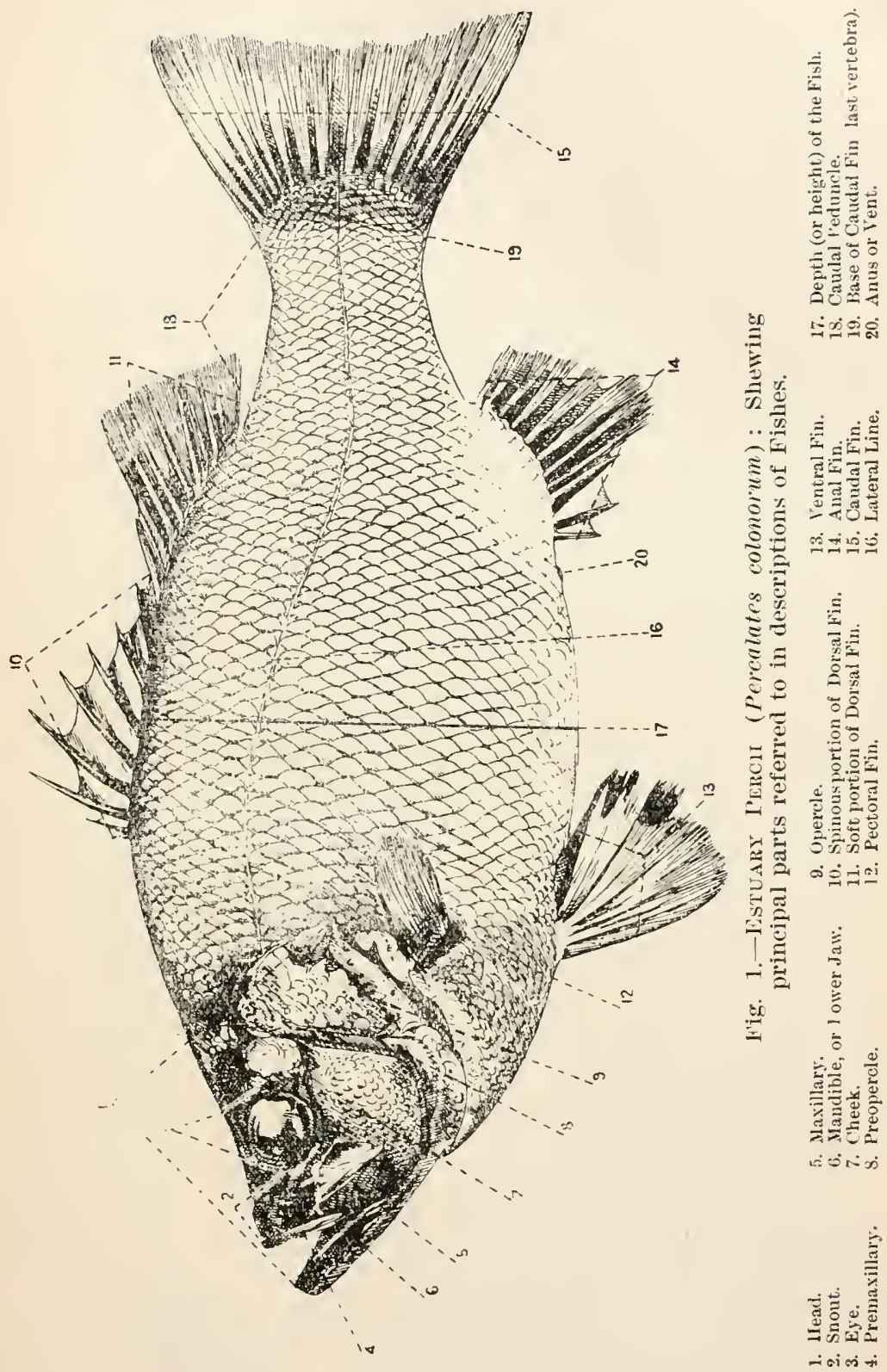
The oranchiostegal membrane is that thin membrane attached to, and just beneath, the posterior portion of the opercle, and supported by cartilaginous or bony rays, known as the branchiostegal rays.

The teeth of fishes are usually conical and pointed, though frequently some are incisor- or molar-like: an instance in which the latter are possessed, being that of the common Black Bream. Other modifications in shape are also to be found, such as in the case of the common Blackfish, where the teeth are comb-like or tricuspid, and also in the Toadfishes, in which the teeth are welded together, so as to form hard, chisel-like plates.

Many of my readers, particularly those who keep aquaria, may have often noticed that certain fishes are able, without any apparent effort, to rise or sink in the water, at will; and perhaps they have wondered what means were employed in doing this. The answer is, that the fish is able to perform this seemingly impossible feat, solely through the possession of what is termed the airbladder (known also as the "swim-bladker" or "sound"). The air-bladder which is one of the most characteristic organs of fishes, is a hollow sac, containing gas, situated in the abdominal cavity, immediately beneath the spinal column. By being compressed or dilated, it influences the specific gravity of the fish; thus enabling it in some instances to rise or sink in the water, without the aid of the fins at all; while in many other species, in which it has not undergone such a degree of development, it is still of very great assistance. In some fishes, only the rudiments of an air-bladder are to be found; while in others, there is no trace of it at all. In the Lung-Fishes, it assumes the function of a simple kind of lung: enabling them to breathe air. In the fishes of the Jewfish family, and also in the family of the Threadfins or Tassel-Fishes, the air-bladder is very large and important.

The eyes of fishes are usually rather large for the size of the body (in some instances they are enormous), but in certain cases they are either very small or else quite rudimentary and hidden by the skin. A familiar instance of a large-eyed fish is the Nannygai, while blind fishes are to be found either in caves or at great ocean depths. 
The eyes are usually situated on the sides of the head; but in the Star-gazers, they are on the upper surface. In a variety of the common Gold Fish, known as the Telescope Fish, they project so much as to appear to be on stalks.

Although many blind-fishes are known from the great abysmal depths of the ocean, where the light of day cannot penetrate, very many species oceurring in these same immense depths are provided with either normal eyes or even exceptionally large ones; and, while it is likely that some of these are able to migrate at times into higher levels, it is more probable that they rely usually upon the light emitted either by themselves (in the case of those supplied with phosphorescent organs); or, by the many denizens of the deep, which are known to be phosphorescent, either wholly or in parts.

The tongue (where it exists) in fishes, is small, hard and hony; so that the sense of taste is probably but very feebly developed; not that it is very necessary, as the majority of them swallow their food either whole or in very large pieces.

All true fishes possess an internal skeleton. In the great bulk of fishes-the Teleosteans-(and also in the Lung-Fishes) this skeleton is entirely of a bony nature: but in the Plagiostomes, which include the Sharks and Rays, it is wholly cartilaginous; ${ }^{*}$ even to the skull itself.

The fins of fishes are of the greatest importance to them, either in maintaining their balance in, or in assisting to propel them through, the water. There are five kinds of fins possessed by the typical groups; these being termed respectively, dorsal, anal, caudal, pectoral and ventral. The first three are called vertical or unpaired fins, while the remaining two are the horizontal or paired fins.

In Teleostean fishes, the fins are composed of spines and rays (known also as "hard-rays" and "soft-rays") : the former being stiff, bony structures, usually connected by a thin membrane; while the latter are comparatively

" That is, composed of gristle. 
weak, jointed, and often cartilaginous: these, likewise. being connected by a thin membrane. Spines are present in one or more of the fins of all so-called spiny-rayed fishes, such as the Black Bream, the Tailer or the Mullets; and even amongst the "soft-finned" fishes certain forms occur, in which single spines are developed on certain of the fins. Familiar instances of the latter are the Catfishes, with their large and dangerous spines in the dorsal and pectoral fins.

The dorsal fin is situated along the middle of the back. In many cases there is only the one-this being very short as in the Herrings, long and continuous as in the Parrot-Fishes, or of an intermediate nature-while in others, such as certain Perches, Mullets, etc., two are to be found: excepting in the case of Sharks and Rays, the first being known as the hard or spinous dorsal, and the second, the soft or rayed dorsal. In certain tishes, like the Sergeant Baker, the Salmon-Catfishes and the Trouts, which only possess one main dorsal fin, there is a second and generally very small,* fleshy one on the back, in the region of the tail; this being known as the adipose fin. In fishes of the Mackerel family, and also in some others, there are to be found both spinous and rayed dorsals; with also, succeeding the latter, a number of tiny fins called finlets. These may really be considered as single detached rays, excessively branched from their insertion on the back, where they are remarkably thick and fleshy.

Upon a study of the dorsal fins of fishes, illustrated within even this little work, being made, it will be found that an immense variety in form exists. In the accompanying illustration, the dorsal fins of a few of our common edible fishes are figured; and, though more widely divergent forms could readily be chosen, they will suffice to show the reader what a great diversity of shape is to be found.

The dorsals, as well as the other fins, among the

* In many tropical species of Calfisles, the adipose dorsal fin is exceedingly large. 
cartilaginous fishes, are so thick, through being covered with skin similar to that of the body, that their rays are completely hidden; excepting in such instances, in which there is a spine inserted in the fore part of the fin. This spine being quite, apparently, intended for purposes of offence and defence, is naked and partially mattached to

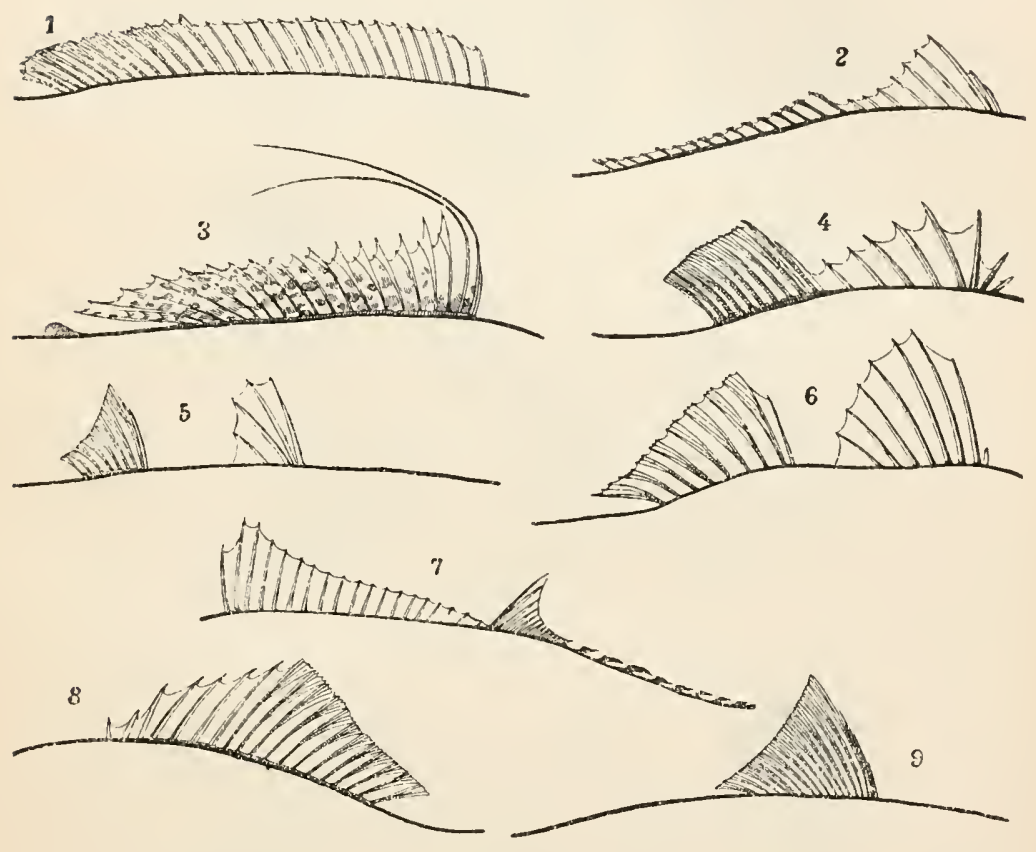

Fig. 2.-Dorsal Fins of Australian Fisurs.

1. Rock Whiting.

2. Australian Salmon.

3. Sergeant Baker.

\author{
4. Estuary Perch. \\ 5. Mullet. \\ 6. Goat.Fish.
}

7. Horse Mackerel.

S. Nannygai.

9. Herring.

the other rays. The Port Jackson Sharks will serve as an illustration of fishes having this find of dorsal fin.

The anal fin usually corresponds in position with the second dorsal; being situated on the under part of the tail, behind the vent. In a great measure, it will be found to depend for its length upon the size of the tail; 
fishes with long tails usually possessing long anal fins. Comparatively speaking, this fin is not subject to a great deal of variation. In the Mackerels and some other fishes, the anal fin is stcceeded by a number of small finlets
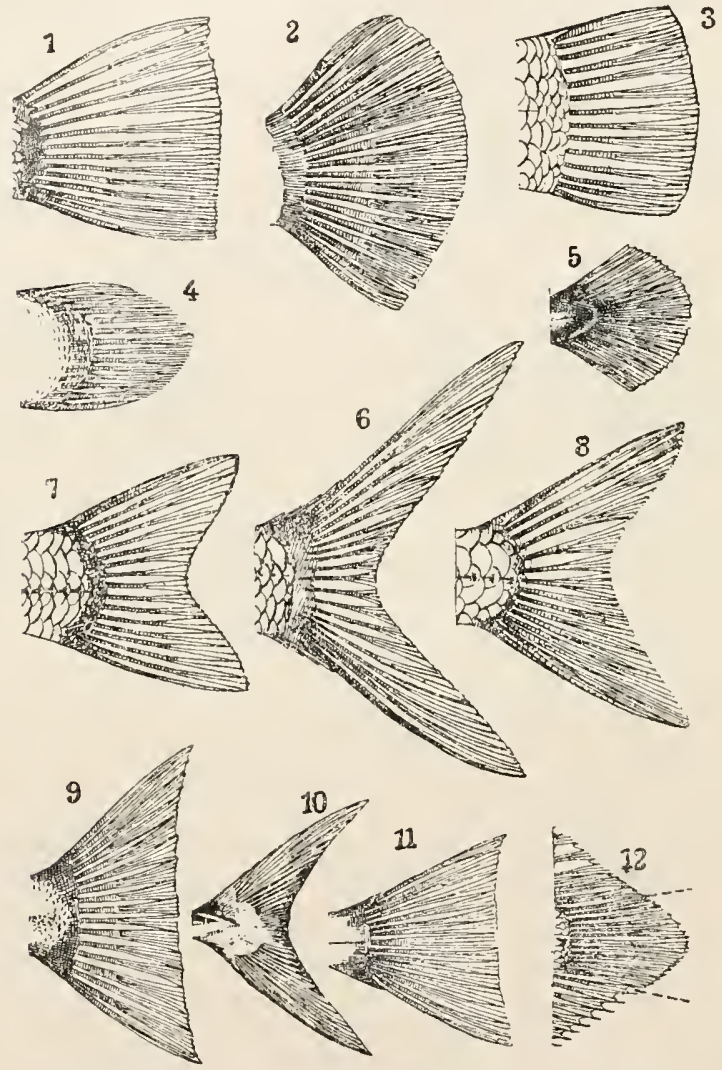

Fig. 3.-Caudal Fins of Australiax Fisiles.
1. Red Rock-Cod.
2. Black kock-Cod
5. Heardie (Ling).
9. Giant Boar-Fish.
3. Blue Groper.
6. Nannyurai.
10. Horse. Mackerel.
4. Flounder.
7. Estuary Perch.
8. Goat.Fish.
11. Kumu Gurnard.
12. Black Sole.

corresponding to those on the dorsal surface, already mentioned. In number, these finlets, both dorsal and anal, may reach as high as nine or ten, though more commonly the number is from five to seven. 
The caudal fin or "tail-fin": Like the dorsal fin (or fins) the caudal is suljject to great variation in shape; in some fishes being slightly or deeply-forked, in others rounded, in others again, produced into a fine point (or even into filaments), while there are all imaginable modifications of these and other shapes. In some cases, the caudal fin is joined to both the dorsal and anal fins: the three combined, making one continuous fringing fin. Familiar instances, amongst many, in which this occurs, are the Eiels, the common Catfishes, the Black Sole and the Australian Rockling.* The candal fin is most highly forked in the Mackerels and other closely allied swiftswimming fishes; in fact a highly-forked tail, may be taken pretty generally as an indication of high speed.

In the accompanying illustration, are shown the tailfins of a few of our fishes; while if the reader looks through the illustrations of fishes which occur in the following pages, the great diversity of form in this appendage will be still more apparent.

The caudal fin is of the highest importance to a fish; its function being to assist in propelling and steering the latter through its aquæous surroundings.

The pectoral fins: These fins represent in the fishes the forelegs or arms of mammals and the wings of birds. They are very important to a fish, assisting it very materially $(a)$ in maintaining its equilibrium, and $(b)$ in guiding it through the water; while in many fishes they are often used-within narrow limits-as a means of propulsion. Like the dorsal and caudal fins, the pectorals are snbject to great modification in shape. More commonly, they are either simply rounded or pointed; but sometimes, some of the rays are produced into fine filaments, or into long finger-like processes. In the Cur1rards and Threadfins some of the pectoral rays are detached from the main fin; in the first instance being finger-like and adapted for "walking" along the bottom; while in the latter, they are more or less prolonged into fine hairs; their function being to act as tactile organs (organs of touch).

\footnotetext{
* In some of these there is really no true caudal fin.
} 
In the Gurnards and Filying-Fishes (particularly the latter) the pectoral fins have undergone a tremendous increase in size, being large and almost wing-like; in the case of the Flying-Fishes, being particularly adapted for sustaining them for a short time, while they are making their flying-leaps through the air.

Though usually of a soft character, the rays of pectoral fins are sometimes supported by a large and strong spine; this being particularly prominent in the Catfishes, in which it is very powerful and barbed; becoming a weapon of defence.

In Sharks and Rays, the pectoral fins are highlydeveloped, being very large. In the Rays (where they are usually termed either "wings" or "flaps") they are so large as to appear to be a part of the body itself : in most cases all the ontward traces of a fin being altogether lost.

The ventral fins rank next to the pectorals in general importance, their particular function being that of keeping the fishes upright in the water. They represent the hinderlimbs of mammals and birds.

In the Eels the ventral fins are completely absent.*

Scales: The skin of fishes is usually covered with scales of some description. In some instances however, these are either rudimentary or entirely absent; while in others (such as certain Leatherjackets, Sharks, Rays, etc.) they are replaced by hardened skin-projections or papilla which give to the surface a velvety or shagreenlike appearance. In addition to these, in certain instances (the Porcupine-Fishes and some T'oad-Fishes) the skin is more or less enveloped with a covering of sharp, thornlike spines; while in others, such as the Knight-Fishes, a coat of mail consisting of bony plates, completely invests the fish.

Scales are of great importance to a fish in the amount of protection that they give to its skin; while to the student of fish-life their number, structure and arrangement are highly-valuable characters for the determination and classification of the fishes themselves.

* In some Eels the pectorals also are ahsent. 
In a general way fish-scales are separated into two great divisions: cycloid-scales and ctenoid-scales.

Cycloid scales are those which have a smooth posterior margin, and a more-or-less concentric striation of the surface. In addition to some others, such scales are usually found on soft-rayed fishes (Parrot-fishes, for instance).
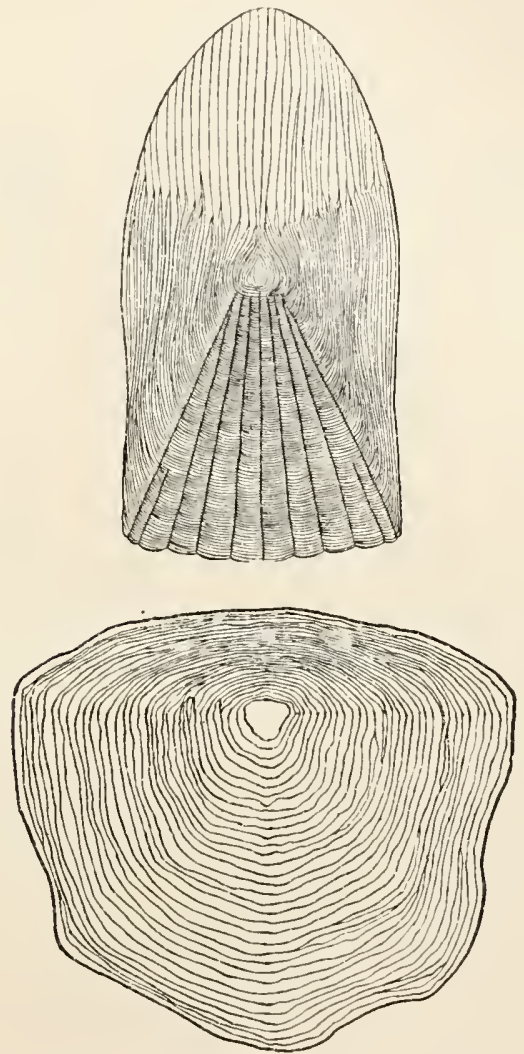

Fig. 4.-T'ypes of Cycloid Scales.

Upper-Body scale of Rock Whitixg. Lower-Body Scale of Australiax Graylis. : (Both ireatly magnified.)

Ctenoid scales have their posterior margin rough or toothed; and such scales are characteristic of spiny-rayed fishes; though cycloid scales occur on some (Mullets and others). 
In many species, both cycloid and ctenoid scales are to be found on the body of the same fish.

In the accompanying illustrations are shown two cycloid and two ctenoid scales, from the bodies of four common Australian fishes.
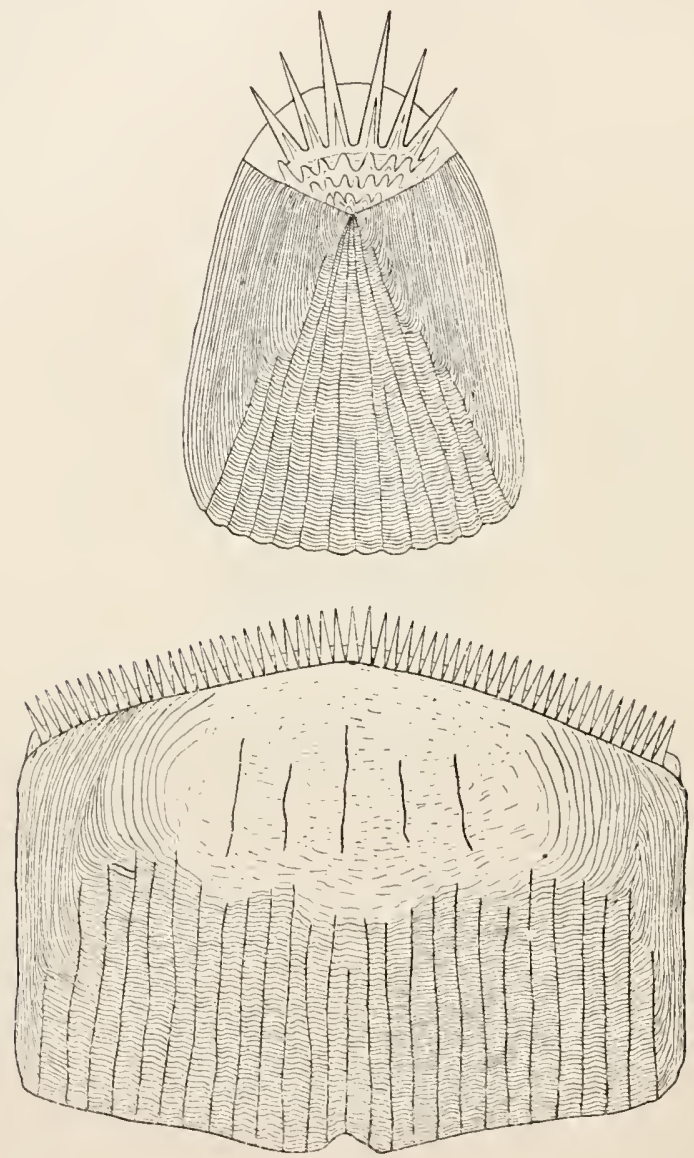

Fig. ז-Types of Ctenoid or Comb-like Scales.

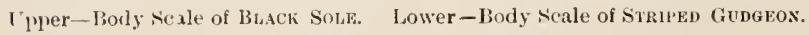
(Both rreatly magnified.)

Incidentally, it may be here mentioned, that fish-scales form most beatiful and interesting objects for the microscope. The study of them is most entertaining and 
instructive, the variety in form and structure being almost infinite.
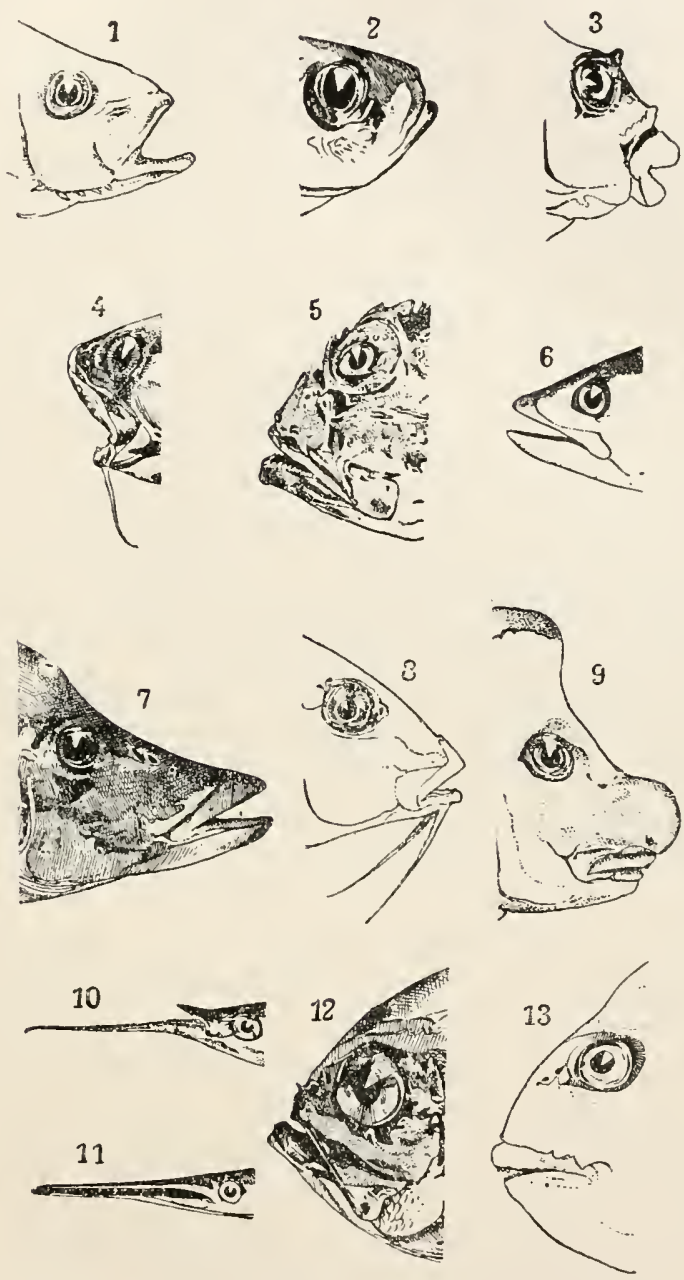

Fig. 6.-Snouts of Itestrilian Fishes.
1. Estuary Perch.
2. Herring.
3. Carp.
4. Bealdie (Ling).
5. Red lock-Corl.
6. Horse-\$lackerel.
7. Giant Boar-Fish.
s. Goat-Fish.
13. Tarwhine.

9. "old Mlan" Snapler.

10. Garfish.

11. Stout Long-Tom.

12. Nannygai.

In most species of the bony or teleostean-fishes, there is to be seen a kind of raised line running through the 
scales longitudinally, along the body from behind the opercle (operculum) to the root of the caudal fin, and even sometimes extending right out on to that appendage itself. This is the so-called lateral line. Where it exists, as in the more typical groups, it is deserving of considerable attention. The scales of which it is formed, are always of a construction different to those on the rest of the body; being perforated in the middle, to allow of the free issue of the slimy, mucous substance which is distributed so plentifully all over the body. Sometimes. as in some of the fishes of the Yellowtail family and others, the scales of the lateral line are raised and crested, while in others, they are developed into spines or prickles.

Many fishes (such as Catfishes, Goatfishes, etc.) are provided with fleshy barbels or "feelers" in the vicinity of the mouth; and, where these are present, they may be taken generally as a sign that the fish is a "bottom" feeder, the barbels being organs of touch (tactile organs).

In fishes, we often find a most wonderful adaptation in shape and colour to suit environment; and the form of the snout is particularly liable to modification, according to the habits of life of a particular species. The accompanying illustration of the snouts of a number of our common fishes, will serve to emphasise this statement.

Sometimes, in addition to a fish possessing a protective colouration, it has irregular, skinny appendages, which simulate seaweed, to a greater or lesser extent. This is shown to some extent in the Red Rock-Cod, and is very highly-developed in the Leafy Sea-horse.

Colouration in Fishes: "Contrary to popular opinion," says Bridge, "it may be doubted if any animals, even Insects or Birds, can vie with living Fishes in the brilliancy and changeability of their colours. The nature of their habitat, the rapid fading of the natural tints after death and the fact that museum specimens, however carefully preserved, afford but a ghostly resemblance to the colours of the living animal, account, no doubt, for much of the prevalent ignorance of the extraordinary extent to which colour-development may proceed in a considerable 
number of Fishes." And certainly this is borne out in our experience with Australian fishes; many of which are possessed of the richest and most glorious colours; colours which in the fresh fish absolutely beggar description.

The Breeding Habits of Fishes: Most fishes reproduce by means of eggs; though many bring forth their young alive. Amongst the Teleosteans, viviparous fishes are seldom met with, the principal number being amongst the Plagiostomes (Sharks and Rays). Fish-cggs are senerally divisible into two kinds; pelagic and demersal. Pelagic eggs are distinguished by their lightness and buoyancy so that they float; usually at the surface of the sea. (In some kinds, the specific gravity is such, that the eggs, while not floating at or near the surface, will remain suspended at a considerable depth in the ocean.) Pelagic eggs are usually of exceedingly small size and are remarkably transparent. A prominent feature in many of them, is the presence of a single, comparatively large, oil globule, on the surface of the yolk, while in others, two or more globules may be present. Eggs of a pelagic nature are never found in fresh-water; belonging solely to marine fishes. The reason-which is, perhaps, sufficiently obvious-is that if the eggs of river fishes were to float, they would in many cases be swept out to sea and destroyed.

Amongst the Australian fishes, at least the following species produce pelagic eggs:-

Sergeant Baker (Aulopus purpurissatus).

Skipper Garfish (Scombresox forsteri).

Sea Mullet (Mugil dobula).

Flat-tail Mullet (Mugil peronii).

Yellow-eye Muliet (Agonostomus forsteri).

Blackfisin (Girella tricuspidata).

Estuary Perch (Percalates colonorum).

Cuvier's Sea Perch (Hypoplectrodes nigrorubrum).

Sand Whiting (Sillago ciliata).

Trumpeter Whiting (Sillago maculata).

Snapper (Pagrosomus auratus).

Black Bream (Chrysophry's alistralis). 
Brown Groper (Acharodus badius).

White-spotted Parrot-Fish (Pseudolabrus gymnogenis).

Rainbow-Fish (Coris lineolata).

Herring-Kale (Olisthops cyanomelas).

Yellowtail (Trachurus declivis).

Trevally (Carant georgianus).

Flathead (Platycephalus fuscus).

Red Gurnard (Chelidonichthys kumu).

In addition to the above-mentioned species, there can be little doubt that most of our marine fishes produce pelagic eggs.

Demersal eggs are characterised by their usually larger size and greater weight: the latter causing them to sink after extrusion from the body of the parent. They also show a tendency to be more-or-less opaque. Many demersal eggs are adhesive; readily adhering to one another or to foreign objects such as sticks, stones, weeds, etc. Demersal adhesive eggs are produced by the Garfishes, the Hardyheads, the Murray Cod and probably by most of our fresh-water fishes. Those of the common Catfishes and of the various kinds of Trout, may be taken as types of demersal eggs which are not of an adhesive nature.

Generally speaking, those fishes which reproduce by means of pelagic eggs, produce an infinitely greater quantity, than do those whose eggs are of a demersal character; and well is it that this is so, as the chance of survival is usually very much less in the case of eggs thrown broadcast on the surface of the ocean, than it is in those which are attached to some object, and which may even be watched over to some extent by the parents.

Of viviparous Teleostean fishes, the small Crested Weed-Fishes of the genus Cristiceps may be mentioned as Australian examples.

As I before stated, the Sharks and Rays are principally viviparous, the exceptions, in Australian waters, being the True Skates (Raia), the Dog-Fishes or Cat-Sharks, and the Port Jackson Sharks. In these the eggs, which are exceedingly large, are encased in a horny covering and 
are usually provided with tendril-like filaments for their attacliment to other objects. Many of my readers are, no doubt, familiar with those wonderful objects, the eggs of the Port Jackson Sharks. These are relatively enormous when compared with the size of the parent itself and the beautiful concentric spiral arrangement of the onter covering, must always inspire a feeling of admiration in the beholder.

The Classification of Fishes: For purposes of reference, fishes-which belong to a class called by Naturalists, Pisces-are separated into two main sub-classes known as the Elasmobranchii and the Teleostomi; with a third and smaller one called Dipneusti or Dipnoi; the latter including the remarkable Lung-fishes. These subclasses are again divided into orders, sub-orders, and many families; the families themselves being split up into genera and species; the gemus and species forming what is called the scientific name. For instance, in the case of the Nannygai, the scientific name is Bery.t affinis; the former being the genus, and the latter the species. Fishes having certain slight affinities with one another, are grouped together under the main divisions, while those showing a greater and still greater natural relationship to one another, are placed in the more and more restricted groups. Generally speaking, this is the plan followed by all Zoologists and Botanists in classifying animals and plants; the idea being to make the system of classification as natural as possible, and as far as possible obviating the formation of artificial divisions. Unfortunately, however ardently a person may desire it, the latter cannot always be carried out in practice; in many cases, through our imperfect knowledge of the groups that we are dealing with. This being so, scientific nomenclature is likely to, and does, change; in accordance with the state of our knowledge. In the accompanying table, I have shown the system of classification followed in this little work. This is (with slight alteration) the arrangement followed by the authors dealing with the fishes in Volume VII. of the Cambridge Natural History (1904).

Incidentally, I might here mention, that a great many 
people find it difficult to understand the utility of technical names for animals and plants: and I here take an opportunity of giving a suitable answer. In doing so, I cannot do better than quote the words of Professor Huxley who, in his work on "The Crayfish" says:"Many people imagine that scientific terminology is a needless burden imposed upon the novice, and ask us why we cannot be content with plain English. In reply, I would suggest to such an objector to open a conversation about his own business with a carpenter, or an engineer, or, still better, with a sailor, and try how far plain English will go. The interview will not have lasted long before he will find himself lost in a maze of unintelligible technicalities. Every calling has its technical terminology ; and every artisan uses terms of art, which sound like gibberish to those who know nothing of the art, but are exceedingly convenient to those who practise it.

"In fact, every art is full of conceptions which are special to itself; and, as the use of language is to convey our conceptions to one another, language must supply signs for those conceptions. There are two ways of doing this: either existing signs may be combined in loose and cumbrous periphrases; or new signs, having a wellunderstood and definite signification, may be invented. The practice of sensible people shows the advantage of the latter course; and here, as elsewhere, science has simply followed and improved upon common sense." 


\section{TABLE SHEWING A GENERAL CLASSIFICA- TION OF AUSTRALIAN FISHES.}

Nore - The principal divisions of the sub-class Teleostomi only are here shown. The Cartilaginous fishes (Elasmobranchii) and the Lung fishes (Dipneusti) being omitted. All the existing Teleostomes in Australia belong to the

Order: TELEOSTEI (Bony Fishes).

\begin{tabular}{|c|c|}
\hline \multirow{8}{*}{$\begin{array}{l}\text { Malacopterygii } \\
\qquad \text { (Soft-finned Fishes). }\end{array}$} & FAMILX. \\
\hline & Elopidx (Giant Herrings). \\
\hline & (Osteoglossids). \\
\hline & Clupeidre (The Dorab). \\
\hline & Salmonicæ \\
\hline & $\begin{array}{l}\text { (Salmons, Trouts, etc.). } \\
\text { Alepocephalidæe }\end{array}$ \\
\hline & Stomiatidae (Alepocephaloids). \\
\hline & $\begin{array}{l}\text { (Stomiatoids). } \\
\text { (The "Beaked Salmon"). }\end{array}$ \\
\hline
\end{tabular}

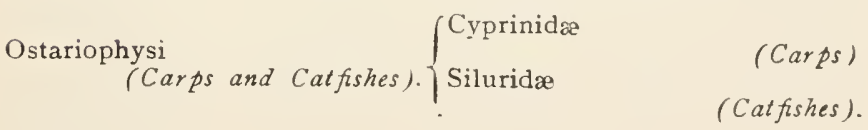

Symbranrhii

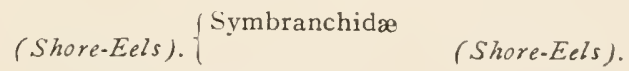

Apodes

(Eels). $\left.\begin{array}{l}\text { Anguillidæ } \\ \text { Murænidæ }\end{array}\right\}$ (Eels).

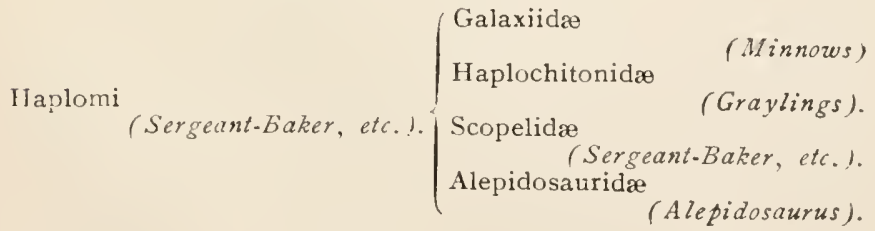

Heteromi ("Spiny Eels"). $\begin{cases}\text { Notacanthidæ } & \text { Fierasferidæ } \\ & \text { (Fotacanthoids). }\end{cases}$ 
Order : TELEOSTEI (Bony Fishes)-cont.

$$
\begin{aligned}
& \text { SUB-ORDER. } \\
& \text { ORDER. } \\
& \text { (Tube-Mouths). }\left\{\begin{array}{lr}
\text { Fistulariidæ } & \text { (Flute-Mouths). } \\
\text { Centriscidæ } & \text { (Sea-Snipes). } \\
\text { Syngnathidæ } & \text { (Sea-Horses). } \\
\text { Pegasidæ } & \text { (Sea-Dragons). }
\end{array}\right.
\end{aligned}
$$

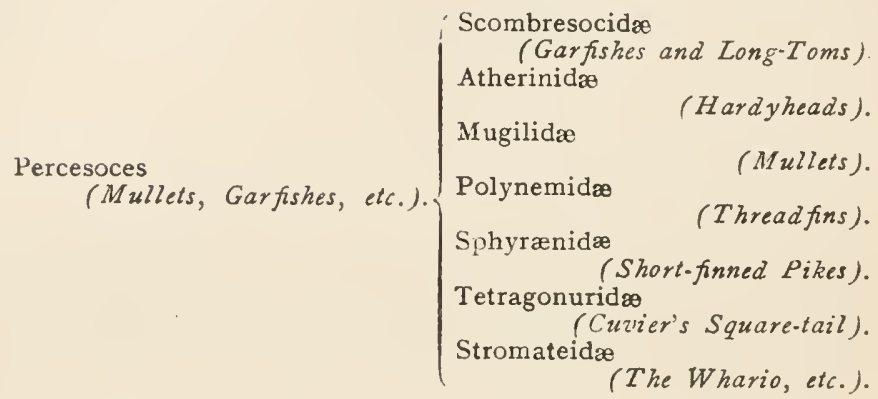$$
\text { Anacanthini (Cod-like Fishes). }\left\{\begin{array}{l}
\text { Macruridæ } \\
\text { (Grenadidær or Whiptails). }
\end{array}\right.
$$

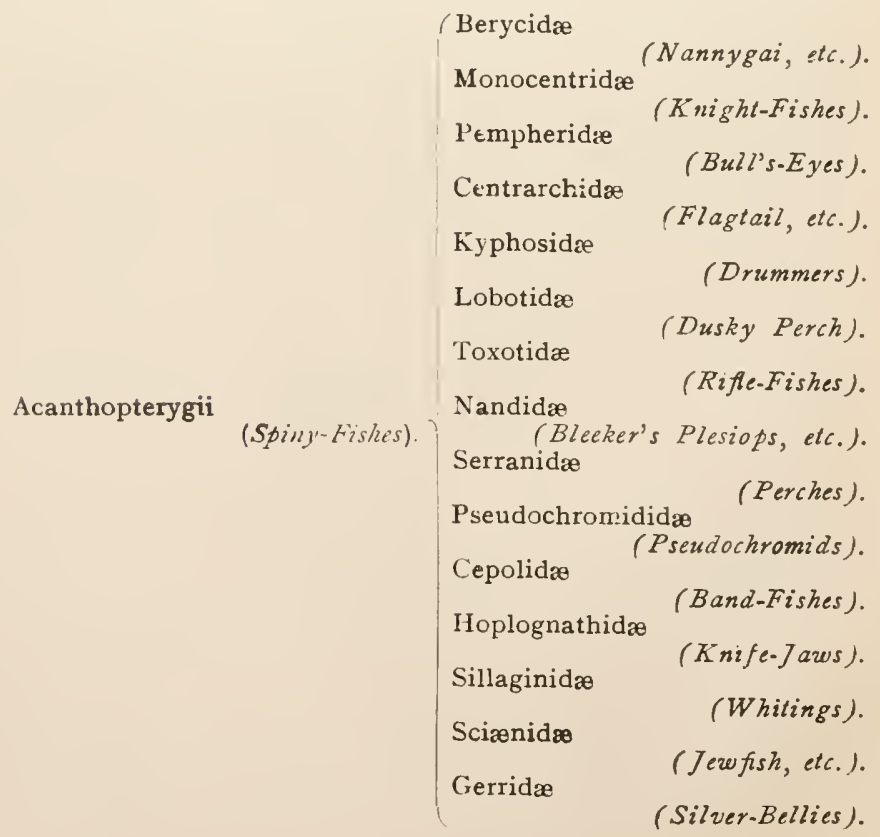


Order : TELEOSTEI (Bony' Fishes)-cont.

SUB-ORDER.

Acanthopterygii (continued
ORDER.

Latrididæ

Aplodactylidæ

(Trumpeters).

(Morwongs)

Pristipomatidæ

(Silver Perch, etc.).

Sparidæx

Mullidæ

(Bream, Snapper etc.).

Scorpididœ

(Goat-Fishes).

Chætodontidæ

Acanthuridæ

(Suecp, etc.).

(Chatodons).

Siganidæ

(Surgeon-Fishes).

(Black Trovally, etc.).

Pomacentridæo

Labridæ Scaridæ (Parrot-Fishes).

(Pomacentrids).

Carangidæ

Rachycentridæ

Scombridæ

(Yellowtail, etc.). (Sergeant.Fish).

Trichiuridæ

Histiophoridæ (Barracouta, etc.)

Luvaridæ

(Swordfishes).

(Luvarus).

Coryphænidæ

Bramidre

(Dolphin.Fishes).

Zeidæ

(Pomfrets).

Pleuronectidæ

(Dories).

Gobiidæ

Echeneididæ

Scorpænidæ

(Red Rock Cod, etc.).

Platycephalidæ

Triglidæ

Cephalacanthidæ

(Flatheads).

(Gurnards).

(Sea Robins).

Leptoscopidæ 
Order : TELEOSTEI (Bony Fishes)-cont.

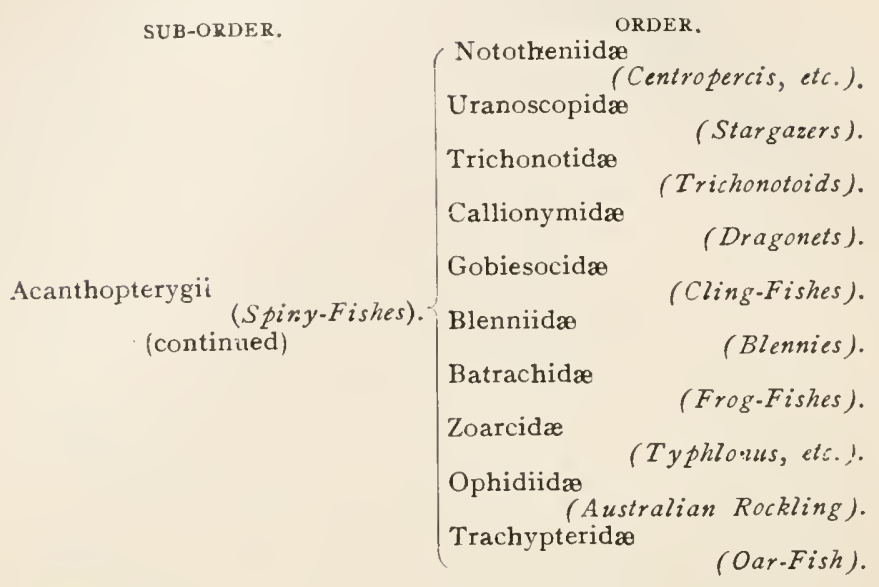

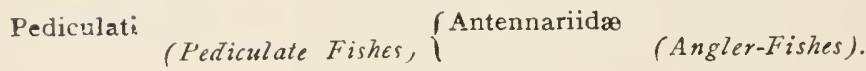

Plectognathi
(Leatherjackets,
etc.). $\quad\left\{\begin{array}{lr}\text { Balistidæ } & \text { (Leatherjackets). } \\ \text { Ostraciontidæ } & \text { (Box-Fishes). } \\ \text { Tetrodontidæ } & \text { (Toad-Fishes). } \\ \text { Diodontidæ } & \text { (Porcupine-Fishes). } \\ \text { Molidar } & \text { (Sun-Fishes) }\end{array}\right.$


Chapter II.

The Giant Herrings_The Osteoglossids_The Dorab-The Herring Family - The Salmon Family--The Alepocephaloids-Stomiatoid Fishes - The Beaked Salmon-The Carp Family-The Catfish Family.

\section{THE GIANT HERRINGS.}

(Family: Elopida.)

THE Giant Herrings are represented in our Australian waters by two important species: The "Ox-eye" or Bigeyed Herring (Megalops cyprinoides) and the Giant Herring (Elops saurus). Though essentially tropical fishes, both of these are obtained as far down our coast as Port Jackson, and possibly still farther south. On the New South Wales coast they are most abundant in the vicinity of the two great northern rivers-the Clarence and the Richmond-and they are still more abundant farther north on the coast of Queensland. In addition, it is probable that they are distributed over the whole of the northern and north-western coastlines of Australia; to what extent is not at present known. They are both carnivorous fishes.

The $\mathbf{0 x}$-eye is very closely related to the famous sporting fish of America known as the Tarpon. It is a large species, attaining a length of several feet, and has remarkably large scales. When freshly captured, its skin has the appearance of burnished silver. The last ray of the comparatively short dorsal fin is prolonged into a long filament. The dorsal fin is situated at about half the distance from the snout to the extremity of the tail. Its eyes are remarkably large, round and lustrous.

In addition to its Australian habitat, the Ox-eye is found along the shores of India, the Malay Archipelago and other tropical localities. It has also recently been obtained in the Philippine Islands. On the east coast of Australia it is known to penetrate the rivers right up into freshwater. 
As, upon a closer acquaintance with its habits beingr made, this fish will very probably be found to have much in common with its congener-the Tarpon-in America, a few words in regard to that famous fish will not be amiss. The Tarpon reaches a length of 6 feet. with a weight of more than 300 pounds. One taken with hook and line on the coast of Florida weighed 209 pounds, while another taken with a harpoon is said to have weighed 383 pounds. Among the names by which this fish is known, is that of "The Silver King." Jordan and Evermann write: "The Silver King is the greatest of game fishes. There is none more celebrated or deserving of higher praise. Only the few fortunate anglers, who, happily situated, are able to spend their winters in Florida or elsewhere on our sontherin coast, have actually experienced the pleasure of Tarponfishing: but every lover of the rod has heard of the Silver King and has hoped that he might some day have an opportunity to test the great fish's strength and skill." As I have suggested, the Ox-eye may some day turn out to be as great a sporting fish as the Tarpon.

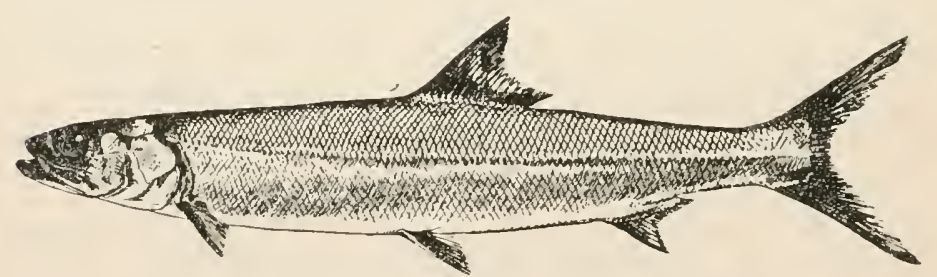

Fig. 7.-Giant Herring (Elops saurus).

The Giant Herring is very different in shape to the: Ox-eye, having a much rounder and more elongated form. The body is covered with small silvery scales, and the eye is partially covered with a transparent fleshy lid (similar to that in the common Sea-Mullet), which, in the Ox-eye, is absent. The dorsal fin is considerably longer (basally) than that in the last-mentioned species, while the anal fin is very much shorter. There is no prolonged dorsal filament as in the Ox-eye. These comparative differences are worth mentioning; as they will be found very useful in any examination of these fishes. The Giant Herring has an even 
wider distribution than the preceding species, being found in all tropical seas. It reaches a length of about 4 feet. An interesting point in connection with this species, is that the young are not like the parents at first, but are ribbonshaped, long, thin and transparcnt: passing through a metamorphosis very similar to that seen in the Conger Eels (page 48 ). They are first band-shaped, with a very small head and loose, transparent tissnes. Then they grow shortcr and more compact, shrinking from $3 \frac{\mathrm{T} / 2}{2}$ inches to about 2 inches in length. The Giant Herring is found at intervals in the Sydney Fish Markets: and, more commonly, in those at Brisbane. It is not at present much sought after as food in Australia. In America, where it also occurs, it is recognised as a "game-fish," and is known under the names of Bony-fish, Ten-pounder, John Mariggle, etc., etc

\section{THE OSTEOGLOSSIDS}

(Family: Osteoglossida.)

THE fishes of this family belong to a very ancient type amongst teleosteans. Externally they have the body covered with very large and hard scales of a mosaic-like structure. The largest fresh-water fish (teleostean) in the world is included amongst these. This is the Arapaima of Brazil. which attains a length of $\mathrm{I}_{5}$ feet, with a weight of upwards of 400 pounds. In Australia the Osteoglossids are represented by two species, both of which are found in Queensland. The principal one is that known to Queenslanders as Barramundi (Scleropages leichhardti). At least two other fishes in Queensland, viz.: the Giant Perch and the Lung-fish, are also known in parts by the name of Barramundi, but it is to the Osteoglossid that it should be restricted. The flesh of this fish is highly esteemed as food in those localities at which it is found. It is said to rise to the "fly" well. Attaining a length of 2 to 3 feet, it has an elongate, compressed body, with a trenchant lower edge. 
The cleft of the mouth is wide, obliquely set, and is armed with a closely-set row of sharp, conical teeth. Two short barbels depend from the lower jaw. The Barramundi occurs in several of the inter-tropical rivers of Queensland, which debouch on the Barrier coastline. The majority of

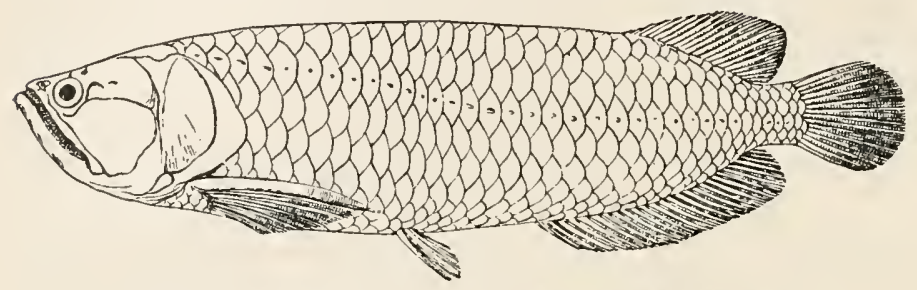

Fig. S.-Barramundi (scleropages leichhardti).

the scales, when fresh, are ornamented with one, or, at most, two red spots.

In connection with the geographical distribution of these Osteoglossids as a family, it is a very interesting fact that it coincides very closely with that of those very ancient forms-the Lung-fishes.

\section{THE DORAB.}

(Family: Chirocentride.)

THE gigantic herring known as the Dorab (Chirocentrus $d o r a b)$ is the sole member of this family of fishes. It abounds principally in tropical seas, but has been taken on

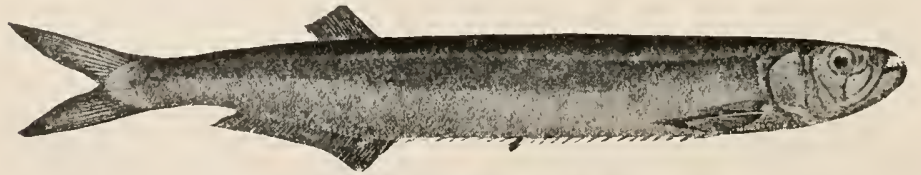

Fig. 9.-Dorae (Chirocentrus dorab).

the coast of New South Wales. In the tropics, this species ranges from the Red Sea to the Malay Archipelago and the seas of China and Japan. It is really quite a formid- 
able-looking monster, as it attains a length of fully 12 feet. When captured it is said to bite viciously at every object within reach. It is not of great value from an economic standpoint. The Dorab (this is the name by which it is known in "the east") has very formidable teeth, an elongate, highly-compressed body, and thin decicluous scales. The dorsal fin is short, and situated opposite the anal fin, which is long. The ventral fins are very small, and have 7 rays.

\section{THE HERRING FAMILY.}

(Family: Clupcida.)

AMONGST the fishes of the world, the herring family is second to none from the point of view of their commercial importance. Though usually of small size, they are remarkable for the enormous number of individuals by which a few of the species are represented, rather than by the multiplicity of the species themselves-though there are a great many species. The fact that some of the most valuable kinds associate at certain periods in immense shoals, accounts for the great usefulness of this family, as a food-supply to man. Probably the next family in order of importance would be that of the Salmonidre. 'The herring family is well represented in Australian waters, and some of the species are destined in the future-let us hope the near future-to become veritable mines of wealth for persons of enterprise in our country. Amongst the more important that are worthy of mention, are the following:-The Pilchard (Chupanodon neopilchardus), the Herring (Sardinella castelnaui), the Sandy Sprat (Hyperlophus spratellides), and the Anchovy (Engraulis antipodum). The large Salmon-Herring (Chanos chanos), the Fresh-water Herring (Potamalosa nor're-hollandice) and the so-called Bony-Bream (Dorosoma erebi) also belong, among others, to this family.

Of the above, the Pilchard is by far the most important, occurring as it does at certain seasons, in enormous 
shoals, which, at times, cover vast areas in our coastal waters, both in the young and adult stages. The complete history of the life and migrations of the Pilchard still waits to be told, but notwithstanding the paucity of our knowledge in regard to this and some other members of the Herring family. we still know enough to enable us to reap a rich harvest annually from them, if we were so inclined; but, instead of doing this, we sit down year after year, allowing the shoals to come and go without any attempt being made to utilise them. Here, indeed, are riches thrust upon us, but we are apathetic and do not heed; for we close our eyes to the bountiful stores that Nature has laid before us and sometimes complainingly ask, "Where are the fish?"

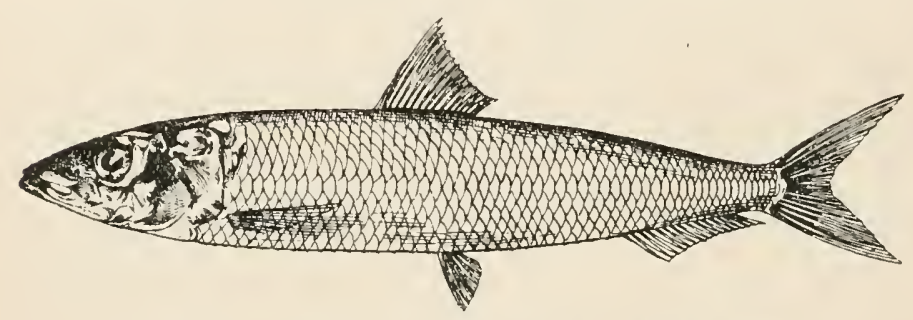

Fig. 10.-Pilchard (Clupanodon neopilchardus).

At the present time the enormous abundance in which the Pilchards, for instance, occur, is very well-known amongst the fishermen; but they also know that if they were to bring along, say, a hundred baskets to the Markets, there would be little, or no, sale for them in their fresh state, and that they would ultimately find their way to "the Tip." In utilising shoals of fishes such as these, combined effort on the part of the fisherman-as producer-and the purveyor or manufacturer (using the latter term in its wider sense) is necessary, if the fishery is to become a success. The Australian Pilchard is to all intents and purposes practically identical, as a food product, with the Sardine of contmerce-a fish, out of the capture and disposal of which, many hundreds of thousands of pounds are gained annually. In regard to their abundance, the same renarks may in a great measure be applied to the Herring, the Sandy Sprat and the Anchovy; these fishes all occurring at one time or 
another in enormous quantities on our coasts. 'The people of New South Wales and other States in the Australian Commonwealth have been brought up from childhood to think only of "the land" and land-problems: to the almost ntter neglect of the sea and its marvellously-bountiful supplies. With the exception of "hand-lining" on outside grounds, practically no fishing methods are practised along our coasts excepting the ordinary ones, whereby hauling or meshing-nets are used in the friendly shelter of our harbours and lakes; or, occasionally on outside beaches. This is not the place for me to go into a general dissertation upon our wilful neglect of what should be one of our great national assets; but I trust that the few remarks here offered will assist in directing the attention of persons of enterprise and resource to a matter so well meriting their attention.

The Pilchard commonly attains a length of 9 or Io inches. In colour it is dark-blue, bluish-green, or greenishbrown above; changing rather suddenly into the silvery colour of the sides. Along each side is a series of darker blotches, making the fish, when viewed from above, very similar to a very different fish-the Common Mackerel. Curiously enough, too, small bodies of the Pilchards are often found among Nackerel of the same size, and vice versâ.

The Pilchard has an enormous range. It occurs along a very great portion of the Australian coastline, being particularly common in the Eastern waters.* It is also quite common in the waters of New Zealand, where it is sometimes known as "Picton Herring:" Beyond these waters, it is found in the Seas of Japan and China, and also along the Pacific Coast of America, from the shores of California to those of Chile. In the United States of America, it is known as California Herring.

The Herring is a comparatively short, deep-bodied fish, having a sharp-edged, serrated lower surface. It is found along our Eastern Coast in large numbers, being frequently obtained-when not in the schooling season-in the company of the pretty little Silver-Belly.

* It has been recorded from the waters of Western Australia, where it is stated to be very common. 
In colour, the upper surface is usually of a bluishgreen: the sides being of a most brilliant silver. The irides are of a beautiful golden or golden-red tint.

This fish attains a length of about 8 or 9 inches.

The Sandy-Sprat is a very small species, but makes up for its reduced size by its great abundance. It is a pretty little fish, almost transparent when alive, frequenting sandy localities along the New South Wales coast, and attains a length of 3 to 4 inches.

With its relative, the Fresh-water Herring, this little clupeid is of some interest scientifically, in that it is one of the so-called "Rough-backed Herrings" which were known

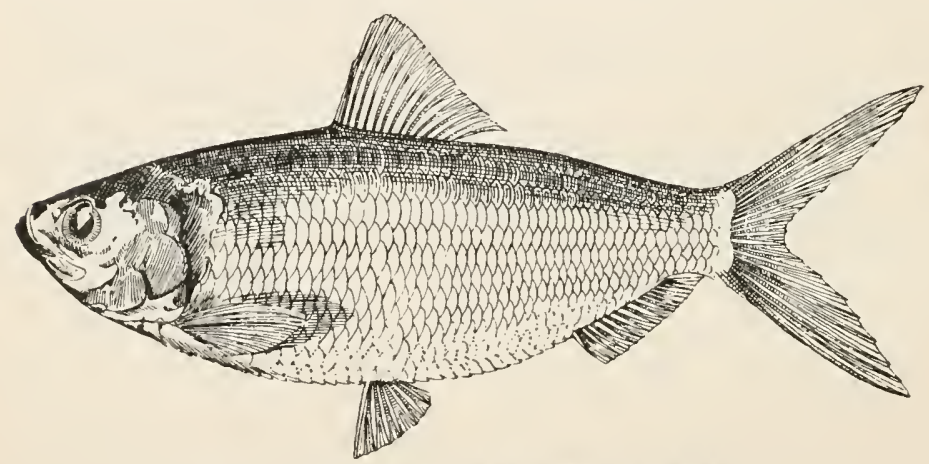

Fig. 11.-Herrixg (Saidinella castelnaui).

to occur in a fossil state long before any existing species were discovered.

The Fresh-water Herring abounds in all the rivers which empty themselves into the waters of the Eastern coast of Australia; with the exception, perhaps, of those in the North of Queensland. In various localities it is known under different names.

It is a beautiful little fish, when fresh, being, with the exception of a narrow greenish strip along the back, of a uniform silvery colour. Soon after capture, a good deal of its brilliance disappears. The back and sides are then of a straw-colour, or olive-green, with the belly silvery; a broad. silvery, dark-edged, longitudinal band running down the middle of the sides. 
This species is often captured by rod and line, taking a bait freely.

It attains a length of about 9 inches.

In New Sonth Wales, it is very abundant in the Hawkesbury, Clarence and Richmond Rivers. During the Winter-time it migrates from the fresher portions down towards the more open waters of the estuaries; there to deposit the spawn, which is probably pelagic (or floating) in its nature. At this time they are enormousty distended (both males and females), with milt and roe.

The Anchovy is one of those fishes that "we have always with us"; but which, like other clupeids, at times congregates in enormous shoals. It attains to a size usually but little larger than the Sandy Sprat. Anongst the herrings, it may usually be recognised by the relatively enormous gape of the mouth.

It probably occurs plentifully over the greater part of the Australian coast; certainly along the Eastern portion.

Out of the shoaling season, it usually frequents fairly-deep water in our harbours, lakes and estuaries.

For all practical and economic purposes, there is no difference between our Anchovies and the famous fishes of that name in the Mediterranean Sea.

The Salmon-Herring is a very large species, exceeding a length of 4 feet. Being rather a tropical species, it is somewhat rare on the coast of New South Wales, but is fairly common along the Queensland coast. It occurs also in India and in other localities. It enters freshwaters, such as the Hawkesbury, Clarence and Richmond Rivers; and, in parts where it is known, the flesh is highly esteemed as food.

This species is known in parts of Queensland as "Milk Fish." a name which has originated amongst Europeans in India; "where," according to Day, "Hyder Ali introducerl it from the sea into tanks of fresh and brackish water, where it still thrives."

The Salmon Herring possesses a large and powerful tail.

The Bony Bream called by the native name of Pibric in parts of the lower Murray (in South Australia), has re- 
ceived its English vernacular name from the excessive number of small and troublesome bones contained within its body, and which effectually prevent it from being extensively used as food. It is found in some abundance in the waters of the Murray River system, and is very largely used in parts as a bait for the capture of Murray Cod.

A few general particulars in regard to its external structure will assist riverside folk to identify this fish for themselves :-

It possesses a highly-compressed body, with a serrated abdomen. The snout is obtusely rounded, projecting a little beyond the mouth, which is narrow. It has no teeth. The eyes are nearly covered by thick adipose (or fleshy) lids, as in the Sea Mullet. The last ray of the dorsal fin is greatly elongated, being produced into a long filament. From the last-mentioned character, the fish is sometimes known as the "Hair-back." In colour it is of a uniform silvery white.

It attains commonly a length of 12 or I 3 inches.

Before leaving this family, I must mention that the fish known in Victoria as the Yarra "Herring" is not a true herring, but is the Australian Grayling: while that known in West Australia as the Swan River "Herring" is one of the Mullets, known in New South Wales as the YellowEye Mullet.

\section{THE SALMON FAMILY.}

(Family: Salmonida.)

Although several species of this family are to be found in many of the fresh-ivaters of Australia at the present time, we have only one indigenous kind, and that is such an insignificant little fish as to be practically of little or no importance. The species that I refer to is the Australian Smelt (Retropinna retropinna): which, though small and only attaining to a few inches in length, is widely distributed; being found in New South Wales, I'ictoria, South Australia, Western Australia, Tasmania and New Zealand. 
might here mention that, though at present it is considered that there is only one species of Retropinna in our waters, I think it is highly probable that a close examination of specimens from various parts will reveal the existence of at least two species.) The Australian Smelt is found in both salt and fresh water, and is to be found in a number of the crceks around Sydney; as well as in the Sydney Water-Supply Reservoir at Prospect, in which there are myriads. In any of the localities mentioned, when captured, it may be at once distinguished from the Ninnows (Galarias)-amongst which it is often found-by its moregenerally silvery appearance, and the possession of a little fleshy-looking adipose dorsal fin situated on the back of the tail, as in all true Trouts and Salmons. This is in addition to the main dorsal fin, which is situated farther forward than is the single dorsal fin of the Ninnows. In New Zealand, where this species is quite common, it is known as "Whitebait." During the early summer months, large numbers of the young, up to 2 or 3 inches in length, are captured at the months of some of the New Zealand rivers. These form the so-called "New Zealand Whitebait" which :s sold by the pound in some of the Sydney fish shops.

Amongst the various kinds of Trout that have been introduced into, and acclintatised in, our waters, perhaps the most important is the Rainbow Trout (Salmo irideus). This fish is a native of the State of California, in America. Of all the many forms of Trout and Salmon it seems to be the one that is best fitted for acclimatisation in parts foreign to its original habitat, on account of its ready adaptability to its surroundings under greatly varying conditionsboth in regard to the quality and the temperature of the water. 'Through the efforts of the United States Fish Commission and the various State Fish Commissions, it is now to be found over a great part of the United States. It has also been introduced into some of the Canadian rivers, South America, Europe, Great Britain, South Africa, New Zealand, and, as already stated, in our own country. In many of the mountain streams of New South Wales, it has thriven wonderfully, being now a source of attraction to tourists and others, as well as providing an occasional meal to numbers of the riverside residents. 
The Rainbow Trout is a very hardy fish, beautifullycoloured, and is very game; consequently it is an ideal sporting fish. It attains a weight of 5 to 6 pounds, or even more; examples of 2 or 3 pounds' weight being common. The food consists usually of worms, insect larvæ and aquatic insects. In its native waters, it is a great enemy of the Quinnat Salmon (which is a much bigger fish, of course), as it is most destructive to the eggs of that species, devouring them in large numbers. Although it usually is found during the whole of its life in fresh-water, under certain conditions it is known-in America-to descend the rivers and pass out to sea, returning again at the breeding season.

The colours of the Rainbow Trout are as follows:-Upper parts, greenish-blue, often purplish; the sides more

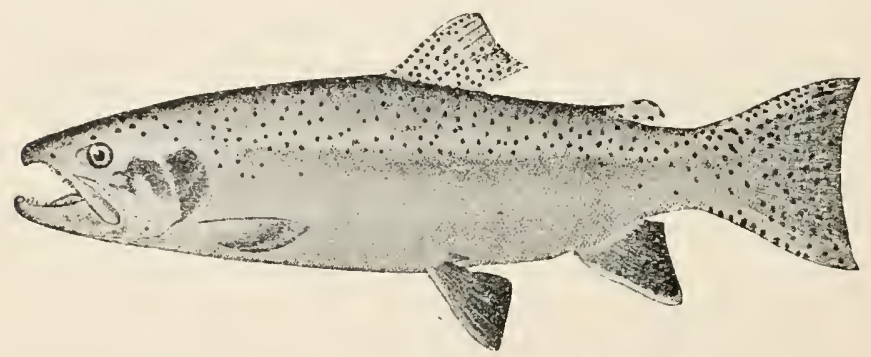

Fig. 12.-RaINbow Trout (Salmo irideus).

or less silvery, and profusely spotted with small black spots, these being most numerous above the lateral line. The head and the dorsal, caudal and adipose fins are also black-spotted. (Sea-run specimens are uniformly silvery, without black spots.) In the breeding season, the broad crimson band on the sides becomes very much brighter. The jaws of the male, during the breeding season, though not greatly distorted as in a number of the Salmonida, are very much larger than those of the female.

In regard to the sporting qualities of this fish, I may state that in America, taking its weight into consideration, it is thought to be a greater fighter than any other trout. Messrs. Jordan and Evermann, the eminent authorities on fishes in America, writing of this species, state that: "In beauty of colour, gracefulness of form and movement. sprightliness when in the water, reckless dash with which 
it springs from the water to meet the descending fly ere it strikes the surface, and the mad and repeated leaps from the water when hooked, the Rainbow Trout must ever hold a high rank. The gamest fish we have ever seen was a I6inch Rainbow taken on a fly in a small spring branch tributary of Williamson River, in Southern Oregon. It was in a broad and deep pool of exceedingly clear water. As the angler, from behind a clump of willows, made the cast, the Trout bounded from the water and met the fly in the air, a foot or move above the surface; missing it, he dropped upon the water, only to turn about and strike viciously a second time at the fly just as it touched the surface: though he again missed the fly, the hook caught him in the lower jaw from the outside, and then began a fight which would delight the heart of any angler. His first effort was to reach the bottom of the pool; then, doubling upon the line, he made three jumps from the water in quick succession, clearing the surface in each instance from $\mathrm{r}$ to 4 feet; and every time doing his utmost to free himself from the hook by shaking his head as vigorously as a dog shakes a rat. Then he would rush wildly about in the large pool, now attempting to go down over the riffle below the pool, now trying the opposite direction, and often striving to hide under one or other of the banks. It was easy to handle the fish when the dash was made up or down stream or for the opposite side: but when he turned about and made a rush for the protection of the overhanging bank upon which the angler stood, it was not easy to keep the line taut. Movements such as these were frequently repeated, and two more leaps were made. But finally he was worn out after as honest a fight as Trout ever made."

This is the fish which the Department of Fisheries has been consistently introducing with great success into suitable New South Wales waters for some years past. The Trout which are distributed are at present hatched out and grown at the Government Hatchery at Prospect, N.S.W., which is in proximity to the Sydney Water-Supply Reservoir.

Amongst others which have been introduced into the rivers of New Soutl Wales may be mentioned the English 
Brown Trout (Salmo fario) and the American Brook Charr (Saliclinus fontinalis). Though these have succeeded in adapting themselves to certain of our waters, particularly those of the Snowy River district. on the whole they are rather more suited for generally colder waters, such as those to be found in Tasmania and New Zealand.

Before leaving this subject, a few words in regard to the introduction of representatives of the Salmonida to Australian waters may not be amiss.

The first experiment was made in ${ }^{8} 82$ by a $\mathrm{Mr}$. Boccius with Salmon ova. The attempt was unsuccessful, and many of the "croakers" of the day said that it was an impossibility and an idle waste of time and money (by the way, there are still a few of these croakers). However, subsequently, a number of other attempts were made; each one being unsuccessful, but each one profiting by the mistakes of the former, until in I864, when success at last crowned the efforts of the devoted few who had worked so untiringly. All of these experiments were made in connection with Salmon (Salmo salar) ova. Since that time many other kinds have been introduced either into Australia or New Zealand. The name of James A. Youl (afterwards Sir James)* will always be coupled with these early experiments, as he took a very prominent part in connection with them.

\section{THE ALEPOCEPHALOIDS.}

\section{(Family: Alepoccphalidw.)}

THIs is a family of deep-sea fishes, somewhat similar in general structure to the Herrings and Salmons.

One species, known as Alcpocephalus niger, has been obtained from our waters at a depth of 1,400 fathoms. This fish has a compressed-though not very elongate-body, covered with small scales. The snont projects beyond the mouth. As the specific name implies, the fish is black.

\footnotetext{
* Sir James Arndell Youl died in England during Jume, 1904, at the age of 95 years.
} 


\section{STOMIATOID FISHES.}

(Family: Stomiatidce.)

THESE are large-monthed and large-eyed fishes frequenting the ocean depths; some being known from a depth of nearly 2,500 fathoms. In some the body is naked, while in others it is scaly. Iil most of the species, the luminous organs known as "photophores" are well-developed. Their enormous mouths are characterized by a most formidable array of teeth.

At least two species of these Stomiatoids* are known from our waters: one having been obtained by the "Challenger" at a depth of 2,440 fathoms off the North-west Coast of Australia, while the other was obtained by the same vessel off the coast of South Australia at a depth of 2, I5O fathoms.

\section{THE BEAKED SALMON.}

(Family: Gonorhynchida.)

THF peculiar fish known as the Beaked Salmon (Gonorhynchus gonorlynchus) constitutes a family by itself. It is remarkable for its elongate, cylindrical body, long. pointed

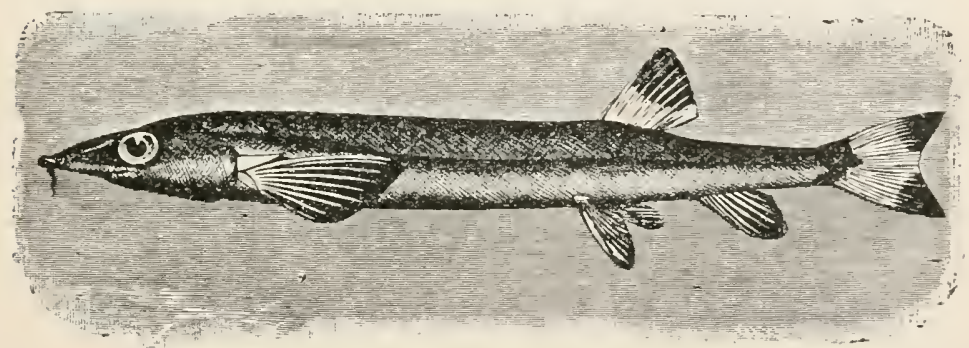

Fig. 13.-Beaked SaLmoN (Gomorhmmehus gonorhymolus).

snout, on the under side of which, and almost beneath the anterior half of the large eyes is the small mouth. From the end of the snout depend two barbels. 
This species has a very extended geographical distribution, being found in New South Wales, Tasmania, West Australia, New Zealand, Japan and South Africa. Probably, also, it will be found to occur along the whole of the southern seaboard of Australia. On the New South Wales coast it is not often obtained, but appears to be more common in Tasmania; while in parts of New Zealand, where. it is common, it is recognised as a food-fish; being known by the altogether inappropriate name of "Sand-Eel."

It attains a length of 18 to 20 inches.

\section{THE CARP FAMILY.}

(Family: Cyprinide.)

THough there is no indigenous member of this family of fishes occurring in Australian waters, certain introduced forms are common enough. Of these, the most important, numerically, is the Goldfish or Golden Carp (Carassius auratus). This species swarms in aquaria and ponds-ornamental and otherwise-in most of the cities and towns of the Australian Commonwealth: and, in addition, is found in nearly all of the rivers, both coastal and inland; as well as the smallest creeks and settlers' tanks in most unheard-of places. It is almost as ubiquitous as the Sparrow is on the land. Its ready adaptability, enables it to put up with great extremes of temperature and to live in water that would suffocate many fishes. There are two wellmarked color-varieties of this species, the one being the wellknown beautiful golden-yellow from which the name of Goldfish has been derived, while the other is of a silvery hue. Outside of ornamental ponds, the latter is the more common form. Carassius auratus is a native of China and Japan; but, having been so easily domesticated and transported, it is now to be met with in all tropical and temperate climes, as well as in many of the colder countries.

Amongst the many curious varieties of this fish which have been developed under artificial cultivation may be men- 
tioned the Telescope Fish and the familiar Japanese Butterfly Fish.

As a food-fish, the Coldfish is of little value, owing to its usually insignificant size.

Others of the Cyprinide which have been introduced into Australian fresh-waters or aquaria are the pretty little Fighting Fish (Betta pugnax), the Tench (Tinca tinca), and the Roach (Leuciscus rutilus). The last-mentioned is of some importance as it is prolific, attains commonly a weight of at least 2 pounds, and is at the same time of some value as a sporting-fish. It is a deep-hodied, herring-like fish, having a silvery body and pretty red fins, the short dorsal greatly resembling that of certain Herrings. It appears to have adapted itself pretty well to our Australian conditions. The Roach is a native of the rivers of Europe.

\section{THE CATFISH FAMILY.}

(Family: Siluride.)

THE immense family of the Catfishes, which embraces about IOOO species, is spread over nearly the whole world; particularly in the fresh-waters, only a comparative few being marine. In size, they range from the tiny "Candiru" of Brazil, of a little over 2 inches in length; up to the huge and hideous "Wels" which is spread over Europe, being particularly abundant in the basin of the River Danube. This is the largest strictly fresh-water fish in Europe; sometimes attaining a length of over to feet and a weight of 400 pounds.

Catfishes are particularly interesting because of the great care usually taken by them in looking after the eggs and young.

In Australian waters, particularly in the tropical or semi-tropical portions, this family is well represented; the most important species being the Estuary Catfish (Cnidoglanis megastomus), the Fresh-water Catfish (Copido- 
glanis tandanus), and the Salmon-Catfishes (Galeiclithy's thalassinus and Galeichthy's australis).

The Estuary Catfish is very common along the coast of New South WVales and probably Victoria also, though in regard to its occurrence in the latter locality little can be said with certainty. It inhabits the waters of our coastal lakes and estuaries, principally affecting muddy and weedy bottoms. Its long eel-like form is quite familiar to most of us, as also its ugly-looking head and month, around which depend eight fleshy barbels or feelers. The first dorsal and pectoral fins are supported by long and strong feebly-serrated spines, which are used for purposes of defence; and, probably-occasionally-offence. Very severe and painful wounds are caused by these spines; and consequently, fishermen look upon this common Catfish as their sworn enemy-a pest little better than the troublesome Stingrays. As the fish loves to lurk among the weeds, waders in muddy places are sometimes wounded in the feet through standing on or near one of these dangerouslyarmed brutes. In this species, the second dorsal fin and the anal fin are confluent with the caudal fin, thus forming a soft fringing fin right round the posterior half of the body, as in eels.

Though the Estuary Catfish is captured in large numbers by means of hook and line or hauling-net, both by amateurs and professional fishermen, it is not because it is sought; as there is no sale for this species. Its horrific appearance has produced a very strong feeling of antipathy in most people, against the tasting of the flesh; which, this notwithstanding, is of good flavour. For the table, it should be boiled and the skin removed. The flesh is not poisonous, though many people think that it is.

In colour the Estuary Catfish is usually of a dark brown or a blackish tint, fading into a dirty white along the lower surface. When living in sandy localities, the prevailing colour is a sandy-grey marbled with brown.

This species attains a length of nearly 3 feet.

The Fresh-water Catfish, unlike its congener just mentioned, is not despised as a food-fish; but instead, is made full use of ; being regarded as a useful and 


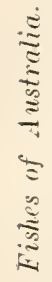

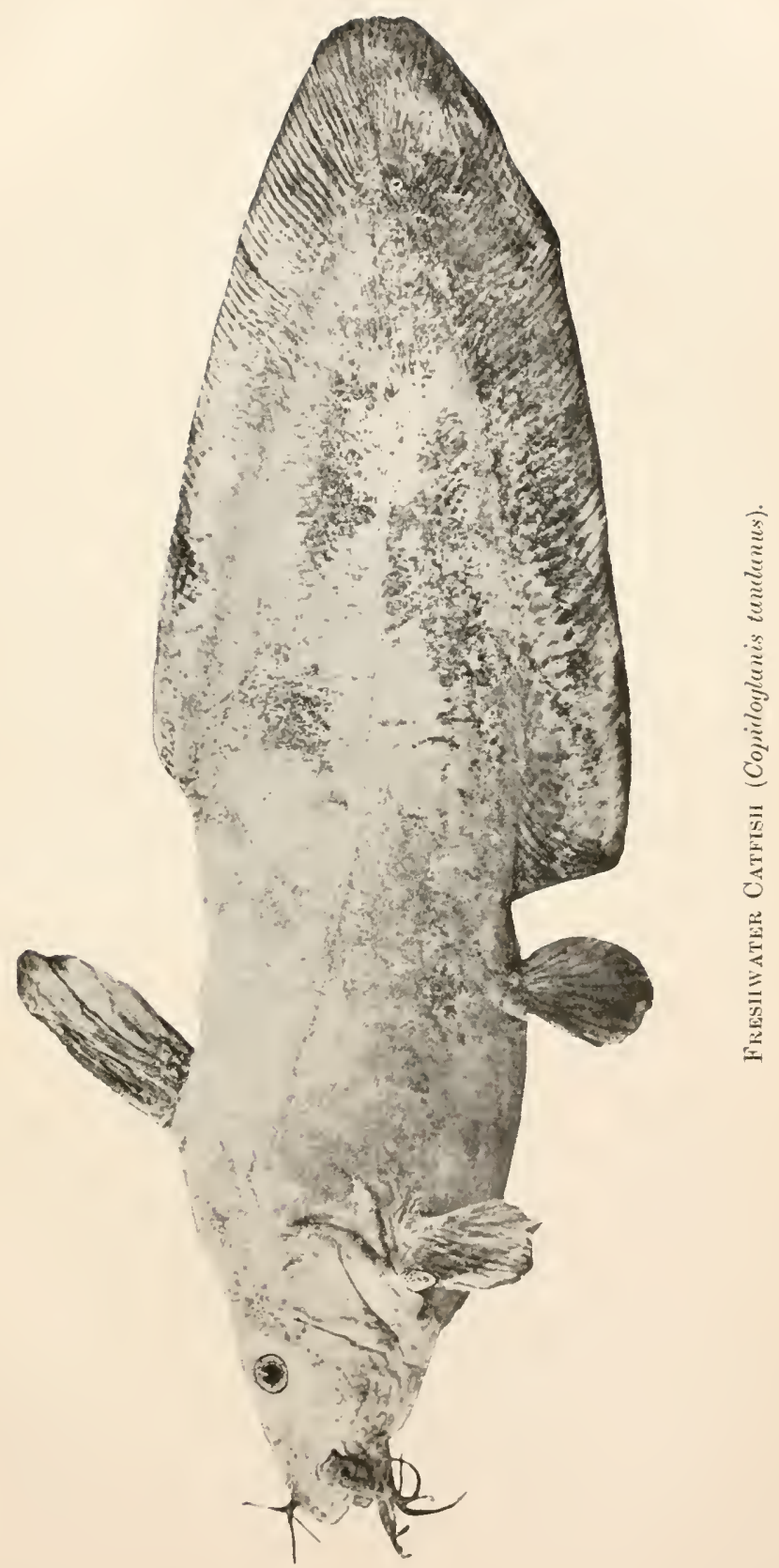

2 

good edible fish in nearly all portions of its known habitat. The latter embraces almost the whole of the huge Murray River system, from a comparatively short distance from the moutl of the River Murray, in South Australia, right up into tributaries of the Darling in Queensland, with also the fresh-water portions of our northern rivers.

In many conntry parts, this species is known as "Jewfish"; that being likewise, the title under which it is usually served np in lotels.

In form, the Fresh-water Catfish is relatively much shorter, and the borly is more elevated and laterally compressed, than in the Estuary Catfish, which it otherwise resembles to some extent. The colour is variable, but is usually of a mottled-grey or brownish.

This species possesses the interesting habit of forming a mound or nest in which to deposit its eggs. This nest is formed either of sandy-grit or pebbles (if the latter are available); and is often at least 3 feet in diameter. During the process of incubation, it is jealously guarded by one or other of the parents. In regard to the formation of this nest, one man who had been fishing for many years on some of the western rivers of New South Wales, informed me that he had seen the fishes carrying pebbles in their mouths to the desired spot. Others state that the mound is formed by a simple fanning motion of the tail; this fanning also tending to dislodge the more minute particles, and so leave the coarser particles behind for the formation of the nest.

The Salmon-Catfishes are totally unlike either of the preceding, in that they possess a well-defined tail portion and an adipose dorsal fin; as in the Salmonid $a$. The hear is very broad and depressed, and is quite hart and bony above. There are six barbels around the mouth. The spine of the dorsal fin, with, also, that of each ventral fin, is very strong. The caudal fin is deeply forked.

The Salmon-Catfishes deposit very large eggs, some of which are nearly $3 / 4$ of an inch in diameter. In all of the species, great care is taken to protect the progeny. Especially does this apply to some of the species in which the male (more rarely the female) takes the eggs in his month, and holds them until they are hatched. This highly- 
interesting habit may be observed in the larger of our common Salmon-Catfishes (Galeichthy's thalassinus) in a number of rivers: notably the Clarence and the Richmond. The discovery of the adults with their mouths full of eggs, has given rise to the idea, prevailing in some quarters, that these fishes eat their own spawn. The smaller species (Galeichthys australis), which grows to a length of about I 8 inches, builds nests upon the sandy beds of rivers, making circular basin-like excavations about 20 inches in diameter; at the bottom of which the eggs are laid, being then covered over with several layers of large stones. As will be seen, this habit is very like that practised by the Fresh-water Catfish, before referred to.

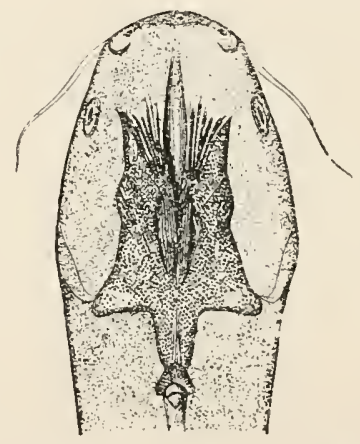

Fig. 14.-Forepart of SALMON-CATFISII (Galeichthys australis).

The Salmon-Catfishes are of little value as food-fishes. In one genus of Catfishes (Aspredo) which does not occur in Australian waters, during the breeding season, the skin of the lower parts of the female becomes quite soft, thick and spongy. After depositing the eggs, the female lies over them and presses them into the skin, in which they remain firmly embedded, until the embryo is hatched out.

Quite a large book could be written dealing with the efforts of Catfishes to ensure the continuity of the species. 


\section{Chapter III.}

The Little Shore-Eels - The True Eels-The Australian Minnows The "Grayling " Family-_The Scopeloids - The Lancet-Fishes-Notacanthoid Fishes-The Fierasferoids-Flute-Mouths or Tobacco-Pipe Fishes-Bellows-Fishes or Sea-Snipes-Sea-Horses and Pipe-FishesSea-Dragons.

\section{THE LITTLE SHORE-EELS.}

(Family: Symbranchida).

ONLY two species of these peculiar little fishes inhabit the coasts of Australia; the principal one being the little Banded Shore - Eel (Cheilobranchus rufus). This is a very small fish, attaining a length of about 4 inches. It varies considerably in colouration, according to location. On the shores of Port Jackson, and in other localities, it is quite common just below low-tide mark, amongst seaweed, in rock crevices or empty oyster-shells.

One species of these symbranchoid eels, which is found in fresh-water streams of Central America, attains a length of 5 feet.

\section{THE TRUE EELS.}

(Families: Anguillide and Murcenida.)

ABout 270 species of these Eels are known from various parts of the world, some of which are found in water having the immense depth of 2500 fathoms.

Many species of eels are found in the waters-botl fluviatile and marine-of Australia. As but little is known in regard to their distribution and occurrence in the other States, I must here confine my remarks chiefly to those of New South Wales. Of the first family, the principal kinds are the Common Eel* (Anguilla reinhardtii), also

* This Eel nay possibly be specifically identical with a conmon Indian Eel-Anyuilla bengalensis-but it does not agree with Day's description of the latter (Fishes of India, p. 659). 
known as the Long-finned Eel, the Conger Eel (Leptocephalus labiatus), and the Silver Eel (Murcenesox. cinereus). The Serpent Eel (Ophisurus serpens) is also a nember of this family. Of the second family, only one species is of any economic importance: and that is the Green Eel (Gymmothora. prasina); while others of the same family are, the Painted Eel (Gymnothora. picta) and the Clouded Eel (Echidna nebulosa).

The Common Eel is found in all the rivers and estuaries of the eastern watershed of New South IVales, and is the principal Eel of the Sydney Fish Markets. It also abounds on the coasts of Queensland and Victoria, more particularly the former. Stray specimens of eels have been reported from high up in western waters in New South Wales; but they must only be looked upon as "strays," and nothing more: as no species of true Eel is known to habitually dwell in those waters.

The Common Eel attains a length of over 3 feet, with a weight of at least ro pounds: a weight of 3 to 4 pounds is, however, considered a fair average.

No special fishery for the capture of this valuable fish. or its allies, at present exists; those that are brought to market being ustrally captured along with other fishes in hauling-nets-usually on muddy flats. As a food-fish it is prized, the flesh being of good flavour.

The name Long-finned Eel is sometimes applied to this species, to distinguish it from another somewhat similar form known as the Short - finned Eel (Anguilla australis). In the former, the dorsal fin extends very much farther forward than in the latter.

In colour, the Common Eel is of a dark olive-brown, streaked and spotted with black; the lower strface being whitish.

Before going any farther, it may be as well to speak upon a subject which ever and anon agitates the public mind, both in Australia and elsewhere; and that is, in regard to the question: "How do Eels reproduce?" the reference being, of course, to Eels which are known to dwell in fresh-waters. 


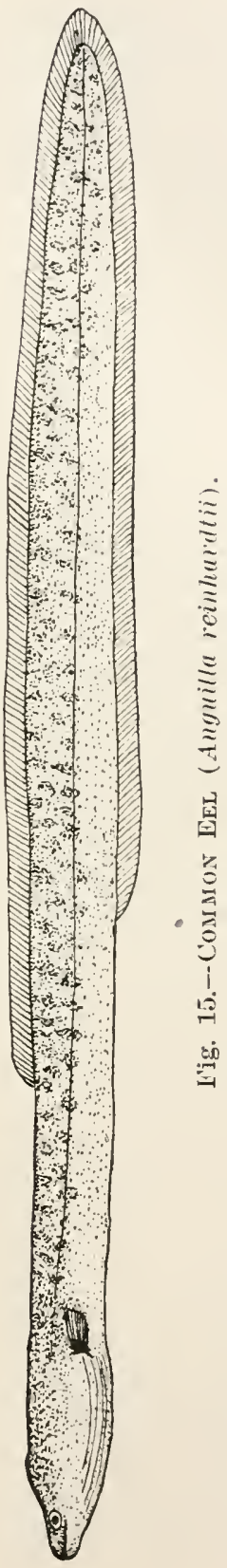


The discussions in regard to the reproduction of Freshwater Eels, are by no means of recent origin, nor did they originate in Anstralia. They rate back to at least as early as the time of the Greek philosopher Aristotle, and perhaps long before that. Aristotle stated in his "History of Animals" that Eels have no sexes, nor eggs, nor semen, and that they rise from ges entera, the entrails of the sea. Strange to say, this curious idea, with certain additional legends and amplifications, was generally accepted by the principal minds for nearly 2000 years after-right up to the middle ages-so great was the veneration in which Aristotle was held. "The Greek poets, following the usage of their day, which was to attribute to Jupiter all children whose paternity was doubtful, were accustomed to say that Jupiter was also the progenitor of the Eel."* One very common idea which has been handed down to us from the "good old times," and which exists even at the present day amongst uneducated people in many parts of Europe, is that Eels are derived from black horsehairs; and, even in parts of England, there are people who believe that Eels may be produced by steeping horsehair (that of a stallion for choice) in water. Many other equally ridiculous ideas might be mentioned, but perhaps sufficient has been said to show what perhaps we all know; that is, that when Man cannot at once fathom a mystery his fertile mind is always equal to the task of finding some more-or-less plausible explanation. All the wild, fantastic stories that were woven round Owls and Bats originated from a want of knowledge of their true habits and life-histories. The origin of the horsehair idea is, no doubt, to be found in the frequent discovery of the long, hair-like Nematode worms which exist in fresh-water; and to people unacquainted with a knowledge of animals, there would appear to be nothing very remarkable in the idea that these apparently "animated hairs" should develop into Eels.

In justice to the originators of all these stories, it must be stated that the reproduction of Eels, has been quite a mystery, even to naturalists, until the most recent times. However, it is now known with certainty that Fresh-water

\footnotetext{
* Jordan and Fvermann, quoting Jacoly.
} 
Eels run down to the sea at spawning time, there depositing their eggs, which are exceedingly minute.

Nothing at present is known in regard to the spawniner of the Australian Eels; but there is absolutely no reason to think that they should differ to any marked degree, from such closely-allied species as the Common Eel of Europe (Anguilla vulgaris) or the Common Eel of America (Anguilla chry'sypa). Jordan and Evermann's remarks in regard to the latter will therefore be worth repeating. as they may be the means of more attention being bestowed upon our own Eels. They say: "The Common Eel spawns in salt water, usually off the mouths of rivers, or mudbanks, to which they go in great numbers at the spawning time, which is in the fall. On these mudbanks the eggs are laid, fertilization takes place and the young eels develop within two or three months after hatching. At the beginning of the second spring, these young find their way to the mouths of the rivers, which they ascend in incredible numbers.* In these fresh-water streams and lakes they remain until of adult size, when they return to the sea for spawning purposes. This seaward migration takes place in the fall, at which time large numbers are caught in traps. During this migration, the Eels, like the Salmon and the Shad, do not take any food. Having once reached the sea, they do not remain close to shore, but go out a distance to deeper water, where the development of the reproductive organs takes place very rapidly. This development is extraordinarily rapid, when the immature state, in which the migrating eels are found, is considered; they probably become sexually mature within five or six weeks after reaching the sea. The spawning then takes place, after which both the old males and females die, never returning to freshwater the second time. . . This is the reason that adult Eels are never seen migrating up stream.

"The down-stream movement occurs usually at night, commencing soon after sunset, is strongest from midnight to 2 o'clock a.m., and ceases an hour or more before sunrise."

* These young eels are known in British waters as "Elvers" and their ascent of the streams in these large numbers is callerl an "eel-fare." 
These Eels produce an enormous number of eggs, the product of one female of 32 inches in length being estimated at $10,700,000$.

Incidentally, it may be here mentioned. that fishes which descend fresh-waters to spawn in the sea are known as "catadromous" species, while those which leave the ocean to spawn up in the fresh-waters are called "anadromous."

Eels pass through a larval existence known as the Leptocephalus stage, in which they are transparent, thin and ribbon-like. These organisms were familiar to the older naturalists, but it was not suspected until comparatively recently, that they were immature Eels, the latter being now definitely established.

In concluding this, I must beg that if any of my readers should come across anything which they may consider of interest in regard to our Eels or their occurrence or movements, they will whenever possible acquaint me with the facts. One fact, well established, however simple it may be, is a link in the chain of knowledge, and we have much to learn in regard to the habits and movements of our Freshwater Eels.

The Conger-Eel is a somewhat larger species than the preceding, and is more essentially marine in its habits.

The Silver Eel is still larger than either of the preceding, as it reaches a length of at least 5 feet. It is really a most beautiful-looking fish. Its body is not nearly so round as that of either of the previously-mentioned species, being more compressed. The jaws are armed with most formidable teeth.

In addition to its occurrence on our coast, this species is found in the Red Sea and the Seas of India and Japan.

The Serpent Eel is a long, thin, snake-like Eel, of a sandy colour, which is often to be found burrowing in the sand of beaches along our coast. It attains a length of from 2 to 3 feet. In this species the end of the tail is somewhat truncated, and is naked; the dorsal and anal fins finishing at a short distance from the point.

The Green Eel is very common along the New South Wales coast, but is not very often seen. This is due to the fact that it lives in rocky situations, and can only be 
captured by means of hook and line. When hooked it is a good fighter. It is of a very savage nature, and its jaws are well-armed with sharp teeth.

The colour of this species when fresh is a bright green. When the fish is taken from the water, however, this colour quickly fades to a yellowish brown, with darker spots.

The Green Eel has even a greater geographical distribution than the Silver Eel.

It attains a length of nearly 3 feet.

\section{THE AUSTRALIAN MINNOWS.}

(Family: Galariider.)

THE members of this family are small, highly-voracious, Trout-like fishes, inhabiting streams in the Southern Hemisphere of the world only; the greatest number of species being found in the waters of the southern half of Australia and New Zealand. Though they are small, some of them being even tiny, many of them are very prettily-marked and spotted, and this, coupled with their activity in the water

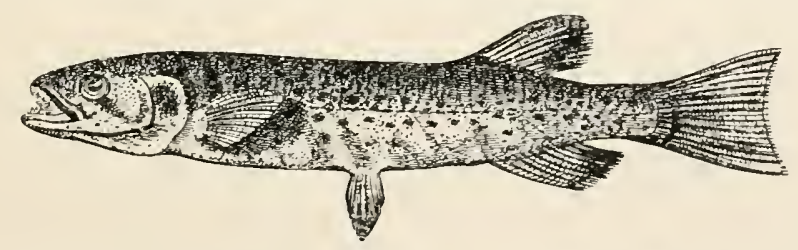

Fig. 16.-Tasmantan Minnow (Galarius truttaceus).

and their habit of swimming and leaping at the surface, has given rise to the name of Mountain Trout, which is so often applied to them. They really take the place of the Salmonfamily in our waters; only one tiny species of true Salmonoir] -the Australian Smelt-occurring here. It is highly probable that these fishes were originally developed from an offshoot of the Salmon-family, in the process of adaptation, 
losing the adipose fin on the back of the tail which is so characteristic of the true Salmonoid. In Tasmania, these fishes are often familiarly known under the designation of "Jollytails."

All of these Minnows are well-adapted for keeping in the private aquarium; and as their habits are so interesting, and they always look so bright and "cheery," I would certainly advise all who can, to partially stock their aquaria with one or more species of them. (In this connection I might add that Mr. Albert Gale, who has been an enthusiastic keeper of the aquarium for many years, has recently succeeded in transporting to Sydney from their cold native waters in the Monaro district of New South Wales, a few examples of the beautiful Kosciusko Minnow and has, since, kept them alive at his residence, Stanmore, Sydney, where they were flourishing at the time that I saw them.)

About Io species of Minnows are known at present from our waters, amongst which, the following at least are deserving of mention: The Sydney Minnow (Galaxias scriba), the Mountain Minnow (Galaxias coxii) the Kosciusko Minnow or "Kosciusko Trout" (Galaxias findla@i), and the Tasmanian Minnow (Galaxias truttaceus).

The Sydney Minnow is a long, attenuated fish: very bright-looking, semi-transparent, and dusted over with small dark spots. It is found in great abundance in most of the small streams or creeks on the eastern slope of the County of Cumberland, swimming at the surface.

It commonly attains a length of 6 to 7 inches.

The Mountain Minnow principally frequents the watercourses of the highlands, on, and in the vicinity of, the mountains of the Great Dividing Range in New South Wales, excepting the southern portion. It is a much stouter-looking fish than the last-mentioned; also, more Trout-like, owing to the presence of a number of vertical stripes or bars on each side of the body.

This species reaches a length of about 7 to 8 inches.

It was originally described by Sir William Macleay in the year 1880, from streams on Mount Wilson.

The Kosciusko Minnow, more familiarly known as "Kosciusko Trout," is a much smaller species than either 
of the two first-mentioned. It is found on the highlands of the Monaro and Snowy River Districts, particularly in the neighbourhood of Mount Kosciusko, the "roof" of Australia, from which it takes its name.

This species is very beautifully marked.

The Tasmanian Minnow is the largest of all these fishes; attaining to a length of fully ro inches. It is very plentiful in many of the streams in the Island-State; affording sport to many an angler.

This fish is still more like a Trout than any of the others, both in conformation and colour.

As I have several times mentioned the likeness of these Minnows to Trout, the reader may imagine that it is diffcult to distinguish between the two, even in a general way; but this is not so. The Minnows lave but one dorsal fin, far back on the body near the tail; there being no soft dorsal or adipose fin: while in the various kinds of Trout, and also in the Australian Grayling, the dorsal fin is situatcd more towards the middle of the back, and there is always an adipose fin at the back of the tail. If this little point is remembered, much confusion will be avoided.

\section{THE “GRAYLING” FAMILY.}

(Family: Haplochitonida.)

THIs family consists of fresh-water fishes which might well be termed the "Salmons" of the Southern Hemisphere. Only two genera are known. One known as Haplochiton occurs in the streams and lakes of portions of South America; while the other-Prototroctcs-is represented by: two species, the New Zealand Grayling (Prototroctes oxyrhychus), which is also known by the Maori name of "Lpokororo," and the Australian Grayling (Prototroctes: marcena). It is the latter with which we are here directly concerned.

The Australian Grayling is a fine little fish, both from its value as food, or viewed as a purely sporting-fish. In 
Tasmania, where it is common, it is known under a multiplicity of names, but chieflv as "Herring" and "Cucumber Mullet." (Of course, there is not much of either Herring or Mullet about it.) It is considered to be the finest and the most delicious of the indigenous fresh-water fishes of that State. It is not found in anything like the abundance with which it used to occur in some of the Tasmanian rivers; a fact which is ascribed by authorities to various causes. (Perhaps the introduced Trout, which appear to thrive so well in those waters, could tell us something about it.) This species also occurs in some abundance, in a few of the Victorian rivers; and at one time, apparently, was common in the Yarra Yarra. With reference to this, McCoy wrote some years ago: "The Yarra Yarra and some others of the rivers near the southern coast, contain in great abundance, a

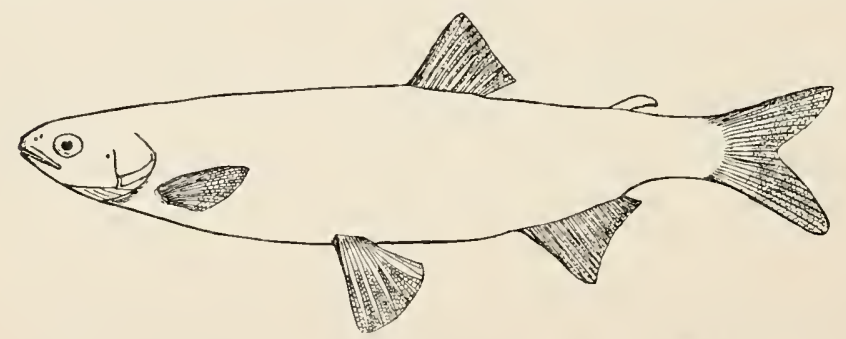

Fig. 17.-Australan (ikaylixg (l'mototroctes marena).

beautiful and active fish; excellent for the table, and affording capital sport for the angler. By ichthyologists following the classification of Cuvier, it would be referred to the Salmonidr, the adipose second dorsal fin being well marked; and so much does it resemble the Grayling* in the cucumber smell when caught, in general appearance, habits, mode of rising to the fly, and playing, as well as in flavour, that anglers are in the habit of calling it now the Australian Grayling." The close resemblance of this fish to the true Salmonida, both in food and habits, assisted the Acclimatisation Society of Victoria some years ago, in their argument that certain of the rivers would serve for the experiment of acclimatising European Salmon and Trout; and

* 'That is, the Kmopean Cirayling (Thymallus vulgari.*). 
later developments liave shown that their confidence was not altogether misplaced.

Probably this fish is to be found in some of the coastal streams of South Australia; but nothing definite appears to be known.

In the rivers of New South Wales it can hardly be stated to be common, and if we were to go on what has been published in the way of records, it must be set down as rather rare; but it appears to me highly probable, that a closer acquaintance with the denizens of our streams, will reveal the fact that in parts at least, it is not uncommon.* The accompanying diagram, which clearly shows the arrangement of the fins, should enable the reader to identify this species, should he come across it in coastal rivers of New South Wales; and, in this connection, it may be mentioned that the Australian Grayling does not possess the beautiful spotted appearance of the introduced Troutnotably the Rainbow Trout, which is likely to be met witin more ofteis than any other-but rather a more uniforns Herring-like colour.

This species is very prolific, and attains a length of about 12 inches.

\section{THE SCOPELOIDS.}

(Family: Scopclide.)

Tin is is a large family of fishes, comprising over Ioo living species, as well as a great number of fossil forms. They are chiefly deep-sea or pelagic fishes; some being found in immense abysmal depths of the ocean. Of those which inhabit our waters, the most important is the so-called Sergeant Baker (Aulopus purpurissatus). This handsome fish attains a length of over 2 feet, and as a table fisl is very fine. The body is elongate and round. Apart froul the Parrot-fishes or Wrasses there are not many species of

* The author will be glarl of any information in regard to the oceurrence of this useful little fish in New South Wales waters. 
fishes in which the sexes are characterised by differences in livery or outward form. In the Sergeant Baker, however, the male may be at once distinguished from the female; because in the former, the second and third rays of the dorsal fin, are produced into long filaments, about double the length of the head.

From the following description of the colours, it will be seen that this species is very beantiful; and incleed when freshly taken, it is surpassing so. The upper surfaces are purple, with a more or less prevailing tinge of red, and with the edges of the scales crimson; the top of the head being sometimes spotted with the same colour. The back and sides have large irregular crimson spots or transverse bands, covering two or three scales in width, not reaching

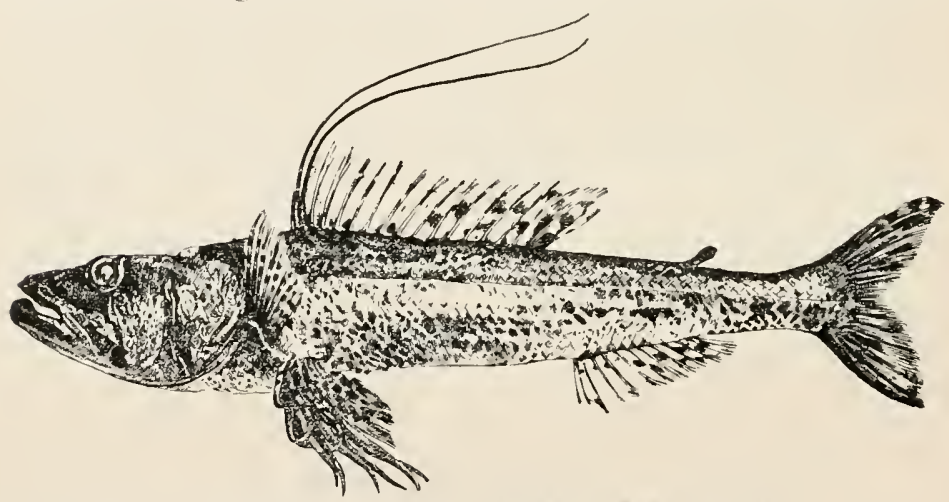

Fig. 18.-Sergeant BaKer (Aulopus purpurissutus).

across the abdomen. The sides are of a paler purplish-red than the back, and gradually merge into the pearly-white of the lower or abdominal surface. The dorsal and caudal fins are of a pale yellowish-red, obliquely banded with rows of crimson spots, which are frequently confluent on the caudal lobes. The adipose dorsal fin (which is characteristic of most of the species of the family Scopclida), is purple along its base and crimson on the upper portion. The anal fin is whitish, or of a pale straw-colour; having across it longitudinal orange bands. The ventral and pectoral fins are yellow, with crimson bands across them.

The Sergeant Baker is captured on the outside fishinggrounds by either hook and line or the Trammel-Net--. 
principally the former. The supply is never equal to the demand for this excellent fish.

It is spread out over the greater portion of the New South Wales coast, and is also known to occur on the coast of Western Australia. Most probably it also is to be found in suitable localities along portions of the coastline of Victoria, South Australia and Tasmania, but authentic records are wanting for these States.

Some of the Scopeloids which live in the occan depths, notably those of the genus Scopelus, are remarkable for the presence of a series of phosphorescent spots known as photophores along the body; and, in some species, also on the head; where they may form large patches on the snout.

One species known as Bathypterois longipes, in which one of the rays of the pectoral fin on each side is tremendously elongated, exists at a depth of over 3 miles.

\section{THE LANCET FISHES.}

(Family : Alcpidosauridee.)

Four or five species of this family are known to exist, and one of them, Alepidosaurus feror, has been found off the coasts of New South Wales and Tasmania. It is a most ferocious-looking fish and is, perhaps, one of the largest

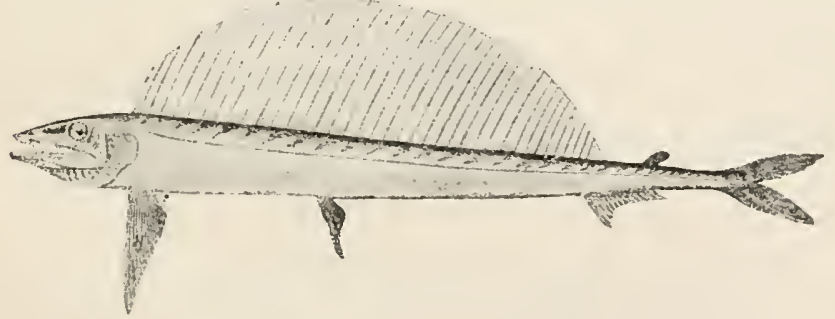

Fig. 19.-Lancet-Fish (Alpielosulute feror).

and most formidable of the fishes of the deep-sea, as it possesses a most fearful-looking "mouthful of teeth" and attains a length of about 6 feet. 
In addition to the localities given above, this fish occurs in deep waters of the Atlantic Ocean; being also occasionally obtained off the coasts of Nova Scotia and Massachusetts. The name of "Lancet Fish"-here used-is applied to this species in the United States of America.

\section{NOTACANTHOID FISHES.}

(Family: Notacanthide.)

THIS is a small family of deep-sea fishes embracing about 9 species, which are characterised by an elongate body, covered with small cycloid scales, the tail tapering to a point and being without a caudal fin. The mouth is small and is placed beneath the snout in a somewhat similar position to a Shark's. The dorsal fin is formed of a series of short, disconnected spines; while the anal fin is very long, extending to the end of the tail.

These Notacanthoids are known to inhabit waters at depths ranging from about 400 down to nearly 2,000 fathoms.

One species-Notacanthus sexspinis-has been obtained from the waters of Australia. But little is known of its distribution.

As in the other species of the genus Notacanthus, so in this, the ventral fins are completely united to each other, forming one fin.

The Type specimen was obtained from King George's Sound.

\section{THE FIERASFEROIDS.}

(Family : Fierasferide.)

THE tiny and highly-remarkable, eel-like fishes which constitute this family, while not being true parasites, spend the greater part of their existence within the body-cavities of 
other marine animals such as Holothurians (more familiarly known as Sea-Cucumbers, Béche-de-mer or Trepang); and bivalve Mollusks such as the mother-o'-pearl shells and certain mussel-shells. They are perfectly harmless to their host, and merely seek for themselves a safe habitation; being in fact "lodgers." Botlenger writing of the genus Fierasfer says: "It has been observed to enter Holothurians by the posterior or anal aperture, either head first or tail foremost; in the latter case availing itself of the suction which takes place alternately with the expulsion of water by that orifice; it remains near the anus, from which it projects its head in search of food outside its host. It is neither a true parasite, nor a commensal or mutualist in the sense given to these terms by Van Beneden, but simply a lodger, 'inquilino,' as Emery puts it. Semper, however, regards Encheliophis a'ermicularis as a true parasite, feeding on the viscera of the Holothurian in which it lives."

Saville-Kent mentions the occurrence of these peculiar and interesting fishes in the bodies of the commercial Holothurians known as "Béche-de-mer," on the Queensland coast; and I have known them to be taken from musselshells on the coast of New South Wales. Occasionally, when inhabiting the shells of bivalves they have been known to become embedded in the substance of the shell itself by the deposition of the pearly matter (which is secreted by the mollusk) over their bodies.

\section{FLUTE-MOUTHS OR TOBACCO-PIPE FISHES.}

(Family: Fistulariide.)

THE "Flute-mouthş" are fishes of greatly elongated form; the foremost bones of the skull being greatly drawn out to form a long tube, terminating in a small, narrow mouth. They are usually scaleless. They are often termed "Pipefishes," a name which should properly speaking be restricted to members of the family Syngnathidce (page 59). 
Dr. Günther describes these fishes as being "gigantic marine Sticklebacks, living near the shore, from which they are frequently driven into the open sea." The largest species attains a length of 6 feet, and is found along the shores of the Atlantic Ocean.

Two species of these Flute-mouths occur in Australian waters; the more abundant being that known as Fistularia depressa. It reaches a length of 3 to 4 feet and is

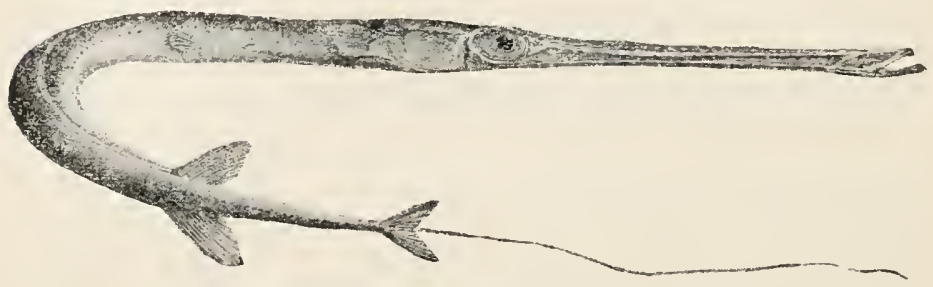

Fig. :0.-Fute-Mouta (Fistularia serrata).

obtained at times in various lakes and estuaries on parts of the Australian coast, more particularly that of New South Wales. It is a very remarkable-looking fish, with its somewhat-flattened body and long snout. Its body is naked and the caudal fin is forked; the two central rays being produced into a long filament. Fishes of the same genus as this one, are known to occur in a fossil state in certain geological formations in Eirrope.

\section{BELLOWS-FISHES OR SEA-SNIPES.}

(Family: Centriscidre.)

HERE we come to another family of grotesque-looking fishes, again characterised by the possession of a long. drawn-out tube-mouth; but instead of the body being depressed and elongate it is compressed and usually short and high. There are two dorsal fins, and in the first is a comparatively enormous spine. The body is covered with small rough scales; with some bony strips on the back and the 
under surface. The most common and most widely-distributed of these fishes, is that known as Bellows-Fish, Trumpet-Fish or Sea-Snipe (Centriscus scolopar. ; which. while occurring on the Australian coast, is also found

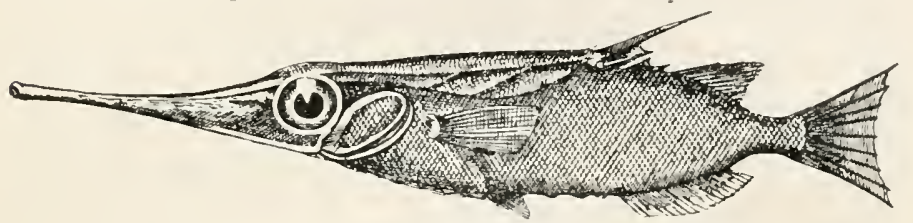

Fig. 21.-Little Bezlows-Fisil (Coutriscus gracilis).

on portions of the coast of Europe. Another and a, smaller one which is found on our coast is the "Little Bellows-Fish" (Centriscus gracilis). This is the species here illustrated. It, also, is very widely distributed. I have obtained this species on fine moonlight nights when it was being washed up during a south-easterly breeze, on the Ocean Beach at Manly, N.S.W.

\section{SEA-HORSES AND PIPE-FISHES.}

(Family: Syngnathidce.)

MosT of my readers are, no doubt, familiar with those comical-looking little fishes known as Sea-Horses; and, though a lesser number will have met with the Pipe-Fishes, these may be described roughly as being really "straightened out" Sea-Horses. In these fishes the gill-openings are reduced to a very small aperture near the upper posterior angle of the gill-cover. They only possess one soft dorsal fin, which, in all of the species, is used largely for locomotion-in some solely. They have no ventral fins, and sometimes one or more of the others are also absent. In the Sea-Horses, the tail is prehensile, being used to hold on to marine plants or other objects while resting or feeding: while in the Pipe-Fishes the tail is not prehensile, and is usually provided with a small terminal fin. The rate of progress of these fishes-particularly the former-is very 
slow, being chiefly brought about by the rapid undulating motion of the dorsal fin-just referred to-this being assisted in some measure in the Pipe-Fishes by lashing movements of the body and tail. It is a very funny sight to see a little Sea-Horse, apparently standing up in the water, looking so prim with its solemn, long-drawn-out face, and moving along without there being (unless one looks closely) any sign of the motive power. Upon an examination of these fishes, it will be found that they are enveloped in a kind of cuirass, formed of bony segments or rings, which are to a greater or lesser extent, according to the species, moveable upon one another; allowing a certain amount of body motion, even in the most rigid of the Sea-Horses. "The attitudes and movements of the Sea-Horses are eninently characteristic. The most frequent is a state of rest, with the tail wound around the stem of a plant or some other substance, and the body is then carried nearly or quite erect. Such is the most frequent position; but notwithstanding the apparent rigidity of the cuirass, almost every other attitude consistent with such a form, may be assumed. The body may be thrown ontward at various angles and even downward and the tail wound around a plant in a double coil. Once in a while, one eye may roll toward you, while another may be passive or look backward or in an opposite direction. It becomes obvious that the little fish can move its eyes independently of each other, and in entirely different ways."

"A comical effect is produced by the way in which the little fishes peer at some object; reminding one of the actions of a very near-sighted person."-(Gill.)

Some of the Sea-Horses are able to make a sharp little snapping sound with the mouth, somewhat similar to that produced by the common "Nipper-Prawn" (Alpheus) of Port Jackson. In the latter case, however, the sound is made by the sudden closing of the larger nipper.

Now one of the most surprising things in connection with this remarkable family of fishes, is that the males are provided with a kind of pouch (in some species there is only a broad groove) in which the eggs are hatched after being deposited by the female. The males take full charge of 
them, and the young remain in the pouch usually for a short time, after being hatched. The males may be at once distinguished by the presence of this pouch, which does not occur in the females. As the breeding season approaches, the pouch becomes thickened and vascular, and thus prepared for the reception of the eggs and the nutriment of the embryos. The males, as is usual in fishes, are somewhat smaller than the females.

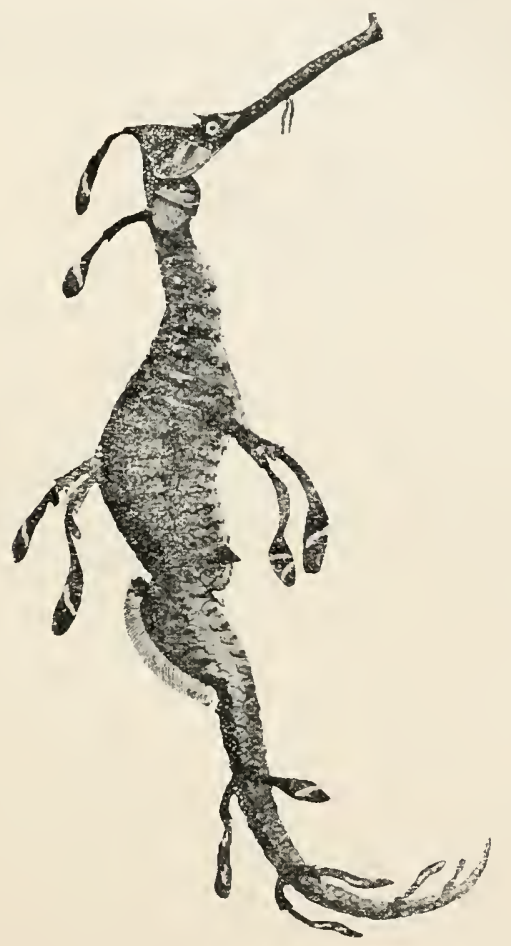

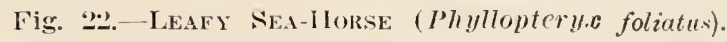

Amongst the Australian representatives may be mentioned the Common Sea-Horse (Hippocampus nor'ehollandice), which is the usual form to be picked up on the beaches amongst shells, or, taken from the fisherman's net; particularly if the haul be made over weedy ground. Wha! in their natural surroundings, it is almost impossible to see these fishes, as their usually neutral-tinted irregular bodies, harmonise so well with their weedy surroundings. 
The best instance, however, that we possess amongst these animals of adaptation to surroundings is that of the Leafy Sea-Horses (Phylloptery.-. In these comparatively large forms, some or all of the smooth bony plates are furnished with long spine-like processes, projecting from their edges; many of them terminating in irregular, leaf-like appendages. They are veritable ghosts of Sea-Horses.

The species here shown is Phylloptery'x foliatus.

Several other species are found on our coasts.

In regard to the common name applied in a general way to these fishes, it may be said that: "The likeness to the conventional knight of the chessboard is much more marked than to a horse's head; indeed, if a spirula-shell or coiled worm were attached to the base of a chess-knight, the Sea-Horse would be well imitated. The ancient name Hippocampus is, therefore, very apt; being derived from the Greek hippos, horse, and kampe, worm or caterpillar. But let no one be deceived by superficial resemblance of parts. The head of the fish and that of a horse are essentially homologous, but here real likeness ends; the contracted part of the Sea-Horse does not correspond to the neck of a true horse, but to the fore-part of the abdomen, there being no true neck in the fish; the lower part of the "neck" of the fish is really the hinder part of the abdomen, and the anus marks its hinder boundary."-(Gill.)

Many species of Pipe-Fishes are found on various parts of our coastline; some of them being very tiny, while one species reaches a length of nearly in 8 inches.

\section{THE SEA-DRAGONS.}

(Family: Pegaside.)

THE Sea-Dragons have the body entirely covered with bony plates, making a strong casing, which is only moveable on the tail portion. The snout is long, and is produced beyond the mouth, which is small and toothless. The pectoral 
fins are very large, while the ventrals are very much reduced. They are all very small fishes inhabiting the coasts of Arabia, China, Japan, the Malay Archipelago and Australia. The Australian Sea-Dragon (Pegası's draconis)

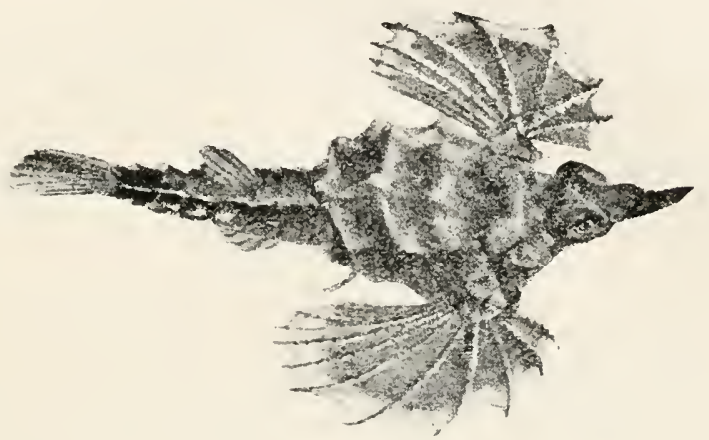

Fig. 23--SEA-Dragox (Pegasus draconis).

is a peculiar little fish obtained occasionally on outside beaches, or in sandy coastal rock-pools. The fishes of the genus Pegasus are possibly unique amongst all fishes, in having the five foremost rays of the pectoral fin transformed into strong spines. 
Chapter IV.

Long-Toms, Garfishes and Flying-Fishes- The Hardyhead FamilyThe Hullet Family-Threadfins or Tassel-fishes-The Pike Family.

\section{LONG-TOMS, GARFISHES AND FLYING-FISHES.}

(Family: Scombresocide.)

Most of this family of fishes (of which, according to Boulenger, about 200 species are known) are marine. Most of them are carnivorous, while some are wholly or partially herbivorous, feeding on certain seaweeds: such as, for instance, the long "sea-grass" which grows on mud-and-sand flats.

Members of this family are found in all tropical and temperate seas, while some occur in a fossil state both in Australia and elsewhere. Among the more important Australian Scombresocids, may be mentioned the Slender Long Tom (Tylosurus ferox), the Stout Long-Tom (Tylosurus macleayana), the Sea Garfish (Hemirhamphus intermedius), the River Garfish (Hemirhamphus regularis), the Barred Garfish (Hemirhamphus far) and the Short-beaked Garfish (Arrhampluss sclerolepis). Though not an important species I might enumerate also the "Saury" or Skipper Garfish (Scombresox forsteri) and the FlyingFish (Cypsilurus melanocercus).

The Slender Long-Tom is, at present, only known from the coasts of New South Wales and Western Australia. It is a very long, slender fish (as its name implies), attaining a length of 2 to 3 feet with a thickness, little greater than an ordinary, large Sea-Garfish. It has long narrow jaws closely set with fine, needle-like teeth. It is a very voracious fish, travelling through the water with an undulatory motion and at a swift rate.

The colours are as follows: Dorsal surface, light green, with three parallel dark lines running along the middle of 
the back, from the back of the head to the beginning of the dorsal fin. Sides iridescent, bright, silvery; the upper portions dotted over with green. Beak: above, dark-green; below, iridescent silvery.

The colours are altogether more Garfish-like than are those of the Stout Long-Tom.

The Stout Long-Tom is not at present known from any other State than New South Vales, though it probably occurs in Queensland. In appearance, it is very different to the Slender Long-Tom, being relatively much shorter or thicker. It reaches a length of about 3 feet 6 inches, though specimens of from 2 to 3 feet are the more common sizes seen. Like the Slender Long-Tom, it is a most voracious fish, but its jaws are more powerful than in that species and the teeth are very much stronger, though not so numerous.

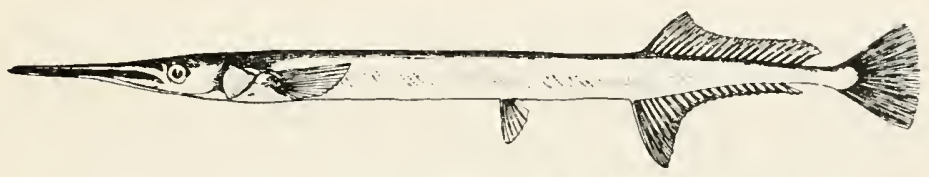

Fig. 24.-Stout Long-Toм (Tylosurus maclcayana) .

The colours are as under: Dorsal surface uniformly dark-green. Anterior half of sides, iridescent whitisin silvery, with a fairly well-marked line of demarcation between the dorsal surface and the sides. In the posterior half, the upper parts of the sides are yellowish, fading into green. A comparison of the colours as here given (they having been drawn by me from fresh specimens) will at once show the possibility of at once identifying the two species by these characters alone.

Both of the above-mentioned Long-Toms are of some importance as edible fishes, the flesh being of good quality. A certain antipathy to them exists among some people owing to the greenisl colour of the bones, there being an impression that green-boned fishes are poisonous; but this idea is altogether fallacious.

The eggs of the Stout Long-Tom, are, for a teleostean fish, comparatively large, in size and colour each egg ap- 
proximating to that of a grain of so-called "pearl" tapioca when boiled.

The Sea Garfish is found in abundance along the greater part of the Australian coastline (including Tasmania): as well as in New Zealand, the Seas of China, Japan, the Malay Archipelago and other waters. From an economic standpoint it must be considered as one of our most important food-fishes. Great numbers of them are captured during the summer months in the lower parts of the harbours and estuaries lying within the waters of $\mathrm{New}$ South Wales: the usual means of capture being the socalled Garfish-net (also known as "Balloo-net," from the Port Jackson aboriginal name of "Balloo"; which was applied to Garfish); a net which possesses a mesh of $1 \frac{1}{8}$ in. in the bunt or central portion, the wings or ends being $2 \mathrm{in}$. This may be used ( I) either as a simple Hauling-net, when the Garfish are on the weedy bottoms (where the eggs-

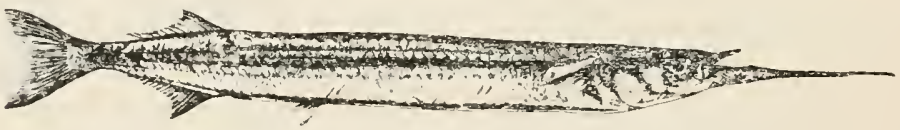

Fig. 25.-Sea Garfish (Hemirhamphus intemedius).

which are demersal, and attached-are deposited); or (2) as a Meshing-net, when the fish are in large schools at the surface of the water. In the latter case the process followed is what is termed "Bull-ringing"; the net being thrown in a circle right round the school. The Sea Garfish is also captured by means of hook and line, to my knowledge, on the coasts of New South Wales and New Zealand. From an edible point of view, this species and the River Garfish are second to none; the flesh being white, flaky, firm and delicious. These fishes also keep sound, under natural conditions, for a longer period than do most others. Of the two species here mentioned, the Sea Garfish is usually by far the larger, attaining a total length of more than 18 inches, with a weight of up to Io ounces; the usual "run" of those marketed, is however, considerably below that size.

The Sea Garfish may be distinguished from the River Garfish in a rough-and-ready manner by the following char- 
acteristics. In the former the body is far more elongate or slim; the scales are much smaller and very deciduous, coming off with the least handling; and the upper jaw has a considerably greater length when compared with its width at the base.

The colours of the Sea Garfish are: "Back bright green, with three narrow dark-brown streaks from the occiput to the origin of the dorsal, immediately in front of which the three meet. A silvery lateral band, broadest posteriorly, and margined above by a narrower lead-coloured band. Lower surfaces, pale-greenish-silvery; posterior part of the ventrals and the pectorals dusky."-(Ogilby.)

The food of this fish consists of pelagic crustaceans, an:l mollusks; as well as of various seaweeds.

The River Garfish: Little is known of the geographical distribution of this fish outside the limits of the New South Wales coastline; though, it occurs in Victoria, Southern Queensland, and, apparently, also in Western Australia. In New South Wales it is highly abundant; particularly along the central area. It is one of those fishes that are "with us always"; its natural habitat being the coastal lakes and harbours and estuaries; in some instances extending almost up to the regions of fresh-water. Large numbers of this delicious little fish are to be seen daily in the various fish-markets in Sydney. Some idea of the great importance of the Garfishes in the fisheries of New South Wales alone may be gathered from the fact that about 5000 baskets* of them are marketed annually. The great bulk of these is River Garfish. In addition to this number, great quantities are captured at various places and "hawked" round by the fishermen themselves, without the fish having passed through the markets at all.

The River Garfish attains a weight of from 8 to 9 ounces, with a length of I 3 or $I_{4}$ inches; those usually captured by the fishermen however, average from 2 to 4 ounces. As previously pointed out it is more robust in form-though smaller-than the Sea Garfish.

The colours are as follows: Back pale-green; the upper surface of the head darker, and with golden reflections.

* A "hasket" equals about 70 to 80 pounds weight. 
Three narrow black vertebral streaks, not extending so far back as the dorsal fin. Two similar but irregular and broadcr streaks between these and the broad lateral silvery band, which is bordered above by a narrow orange streak. There is a faint black spot at the base of the pectoral fin.

The River Garfish is usually found in considerable abundance on sand-and-mud flats, where these are covered with "sea-grass," upon which it, to a great extent, subsists.

The Barred Garfish : This fish is occasionally obtained on the coast of New South Wales, and is fairlycommon in parts of Queensland, being taken in some abundance at Cooktown and Thursday Island. It is very widely distributed, being known to occur in the waters of the Red Sea, the East Coast of Africa, the seas of India and the Malay Archipelago. It is a large species, attaining a length of 15 inches.

This Garfish may be readily distinguished by its heavy build; having, roughly, the body proportions of the Shortbeaked Garfish. As compared with the River Garfish, it may be stated that the body is very much more bulkylength for length-while the beak is considerably longer, the scales are larger, the tail is longer and more-deeply forked and the ventral and anal fins are set back farther along the body.

In life, the back is a dark bluish-green, there is a silvery band along the sides and there are four or five prominent dark bars or blotches along the upper half of each side.

The Short-beaked Garfish is a native of New South Wales and Queensland ranging from Port Jackson on the south to about the coast of Central Queensland or possibly still farther north. On the coast of New South Wales it is most abundant in the lower portions of the Clarence and Richmond Rivers. In each of those rivers, as well as in other portions of its habitat, it ascends right into the fresh-water.

From all of our other Garfishes, this species may be it once distinguished by the relative shortness of its beak, which-comparatively speaking-projects but a short distance beyond the month. It is also very stont-looking, and the scales are large and not very deciduous. 


\section{LONG-TOMS, GARFISHES, FLYING-FISHES. 69}

This fish attains a length of about ${ }_{5} 5$ inches, examples of that size weighing about 9 ounces. The approximate average of those brought to market is from 3 to 4 ounces.

Like its congeners, the Short-beaked Garfish is a most delicate fish, and is highly appreciated for table purposes. During the cooler months, large numbers are captured and are brought from the Clarence and Richmond Rivers, to the Sydney Fish Markets for disposal, there finding a ready sale. The fish could be captured just as easily and in the same numbers, during other parts of the year; the reason that they are only forwarded (in any numbers) during the cooler months being, that under existing means and conditions of transport they will not "carry" very well during the warmer weather. Fishermen living and working at a distance from city markets, labour under difficulties, which local fishermen and those able to send their fish daily by rail know little of. Sometimes boats are overdue through either stress of

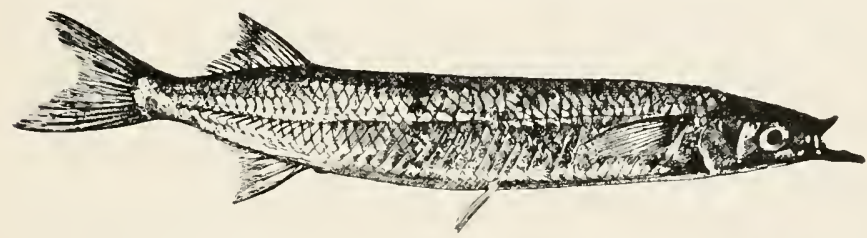

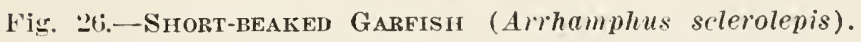

weather or perhaps inability to cross the river-bars. Often, again, a boat may be delayed within a river, with a large consignment of fish aboard, waiting a favourable opportunity to "cross out" over the bar on her homeward journey; the result being that, at times, large quantities of what is really valuable food, have to be thrown overboard.

The diet of the Short-beaked Garfish is somewhat similar to that of the River and Sea Garfishes, though perhaps the fish is slightly more carnivorous.

In colour it is greenish above, being darker towards the head. The lower half is of a dirty-whitish tint; or, when fresh, a semi-transparent, pale, yellowish-green. There is a broad silvery band on each side. As in the other Garfishes, the end of the beak and the membrane below it are very brightly tinted. 
The Skipper Garfish is a pelagic species, frequenting the open ocean and outside coastal waters, rath r. than the inlets. It is very widely distributed in seas other than those of Australia, most probably occurring all throughout the latter; though seldom coming under notice owing to its being very rarely taken in the fisherman's net.

This species may be identified by the following characters: The colour of the back is a deep bluish-green or an olive-green; while the belly and sides are brilliantly silvery. It possesses a number of small finlets behind both the dorsal and anal fins (somewhat similar to those of the Mackerel family). Instead of there being only one jaw produced so as to form a beak, as in the other Garfishes; in the Skipper both are prolonged, and are thin and flexible, reminding one somewhat of the beak of the bird known as the Avocer; excepting that the beak is not curved as it is in the bird mentioned.

The Flying - Fish: Several kinds of Flying-Fishes inhabit Australia's seas. These, like the preceding, are usually found in the open ocean, in large shoals ; being most noticeable for their interesting and graceful aërial "flights." In some parts of the world, at certain seasons when these fishes are present in large numbers, many boats engage in their capture; as they are considered excellent eating.

In the Flying-Fishes, the paired fins are greatly enlarged, the pectorals enormously so; being comparable in point of size to the wings of certain birds. It is this character, which enables these fishes to indulge in their so-called "flights." The term, however, is rather a misnomer; as these fins act more in the capacity of parachutes, than as wings. "Nearly all" of the Garfish family "are in the habit of making great leaps out of the water; this tel1dency culminating in the Flying Fish (Exocotus), which skip or sail through the air in a manner, the explanation of which has given rise to much controversy. According to the latest evidence, the sole source of motive power is the action of the strong tail while in the water; no force is acquired while the fish is in the air. The pectorals are not used as wings but as parachutes."-(Boulenger.)

The Flying-Fish which I mentioned-Cypsilurus 
melanocercus-is found on the New South Wales coast; reaching a length of about $\mathrm{I} 6$ inches.

Amongst the other species of Flying-Fish occurring in our waters, may be mentioned Exocortus cvolans-a very widely-distributed species.

\section{THE HARDYHEAD FAMILY.}

(Family: Athcrinider.)

THE nembers of this family are small carnivorous fishes, inhabiting the seas-and, to a lesser extent, the rivers-of the temperate and tropical zones. They are characterised by the possession of a more-or-less elongate, somewhat rounded body covered with scales of moderate or fairlylarge size. According to Boulenger, about 65 species are known from various parts of the world; these being referable to I4 genera.

In general form they are not unlike the fishes of the Mullet family: possessing, as do the latter, two short, widely-separated, dorsal fins. Most of them are shorefrequenting fishes; but few being found in ocean depths.

In Australian waters the Atherinidce are represented by a number of species, the most familiar of which is the common Hardyhead (Atherina lacunosa). Another, and a highly interesting, member of this family is the tiny but beautiful, Blue-eye (Psendomugil signifor), which deserves to be better known.

The Hardyhead is very abundantly distributed along the coast of New South Wales and Queensland, as well as along the shores of other portions of Australia. In addition, it occurs also, in the seas of East Africa, India, the Malay Archipelago and other localities. At times, on the New South Wales coast, huge shoals of this little fish congregate; forming dense masses. Ordinarily it is to he found in great numbers, spread out over the sandy bottorns and slopes of heaclies in our inlets. As it readily takes a 
bait, it is often captured by the small boy when he is out for sport and to whom all fish is flesh, however small the former may be.

The average size of full-grown Hardyheads is from 5 to 6 inches. Though small, they are excellent for table purposes.

The Blue-eye : This is indeed a very wee fish, adtults only averaging from $I / 2$ to 2 , inches, in length. Though it is never likely to grace our tables, it is destined in the future to play a highly-important part as an aquarium-fisha sphere for which it appears to be admirably adapted. Let us halt a little here to remember that, in performing the function of providing for us food for reflection and recreation it will give us an infinitely-higher sense of satisfaction than could ever be brought about by the mere satisfying of the grosser demands of the stomach.

The Blue-eye is sprightly, vivacious and an active swimmer; being, in addition, very tenacious of life, and, therefore, embracing, in its little self, all the qualities which go to make up a desirable aquarium-fish. Its common name is derived from the blue-colour of the irides of both sexes. In general shape it is more Mullet-like than any other species of the Athcrinida. The male is far more handsome than the female; the second-dorsal, anal and caudal fins being greatly elongated; each being beautifully barred with yellow and black. The beautiful colours are particularly noticeable during the spawning season, which is the summer-time. The body is usually of a silvery tint on the sides, the back being somewhat greenish. If in very dirty waters, the body-colour is often a yellowish-brown, and only slightly silvery. But little is known in regard to the habits, and, nothing so far, in regard to the life-history, of this entertaining little Atherinid.

(My friend Mr. Albert Gale, of Sydney, has furnished me with some interesting information in regard to the Blueeye. While at Cook's River (near Sydney) recently, in pursuit of material for his aquaria-of which he is an enthusiastic keeper-he was attracted by the rapid evolutions of several male Blue-eyes at the surface of the water; the females being a little distance below. Contriving at last 
to capture some of these with his landing-net, he was much astonished to find, that one of the males was of a most brilliant coppery-gold. This colour it retained for some time after capture. Mr. Gale took home with him some of each sex, and he found by close observation that whenever a female Blue-eye was near, the males became greatly excited and chased each other incessantly; meanwhile exhibiting to a greater or lesser extent the beautiful coppery-gold tint already mentioned. They were found to be quite as pugnacious as the so-called Fighting-Fishes (Betta puguax).

This sudden exhibition of colour will strike the observer as being of great interest : as it, most probably, is intimately connected with one of the processes of sexual selection; even though it may be brought about by anger or jealousy on the part of the male.)

The Blue-ere occurs to my knowledge along the New South Wales coastline, from Bateman's Bay to Clarence River and has been recorded from the coast of Queensland, living in either fresh or brackish water, and, possibly, even salt-water. (Those persons in the neighbourhood of Sydney, desirous of obtaining specimens for the aquarium may capture them at any time by means of a small landing-net in weedy patches in Cook's River, particularly above the old dam at Canterbury.)

\section{THE MULLET FAMILY.}

(Family: Mugilida.)

THE Mullets, or, as they are often termed, the "Grey Mullets," are a very important family. They are distributed over the greater part of the world; inhabiting the fresh-waters and coasts of all tropical and temperate regions. None of them are known to occur in very deep water. 'They all feed, more or less, upon the organic matter contained in 
mud, there being a special apparatus. formed by a moditication of the pharynx, for the purpose of filtering out, to a great extent, the coarser particles or matter that is unfit for food. This filtering apparatus prevents the passage of foreign bodies, both into the stomach and through the gillopenings. In feeding, these fishes project the more-or-less telescopic mouth, taking a mouthful of mud or sand, or of both combined, as the case may be ; and, after having worked it about for some time between the pharyngeal bones, they eject the rougher or more unsuitable portions. The hinder purtion of the stomach is worthy of mention, inasmuch as it is modified to form a kind of strong muscular gizzard, which is almost globular, and which suggests somewhat that organ in birds. Anyone who has gutted a Mullet must have noticed this peculiar-looking organ.

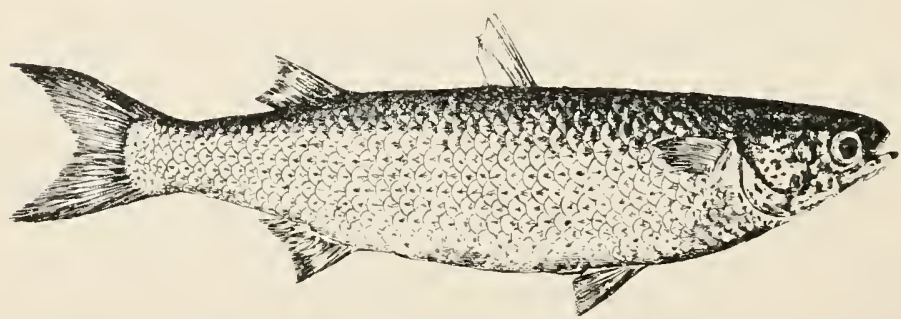

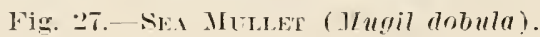

Of about Ioo known species of the Grey Mullets, neari! a quarter-at least-inhabit the coasts or streams of Australia; some of them growing to a large size. From an economic point of view, our Mullets are of the greatest importance; and, they are likely to be of still-greater in1portance to us in the near future. As it would be quite impossible within the limits of our little volume to speak upon even half of the Australian forms, I must content myself with a reference to some of the more important ones. These are, at present, as follows: The Sea Mullet (Mugil dobula), the Flat-tail Mullet (Mugil peronii), the Diamond-scaled Mullet (Mugil waigiensis), the Sand Mullet (Myxus elongatus), and the Yellow-eye Mullet (Agonostomus forstcri). Let it be at once remembered that each of these, as in so many other fishes, is known by at least 
half-a-dozen other common-names in varions localities; this being the cause of a great deal of popular confusion and misapprehension in regard to them.

The Sea Mullet is the largest, as well as the most important, of all our Mullets. This fine species inhabits, if not the whole, nearly the entire coast of Australia. In addition it is found at Lord Howe Island, the New Hebrides, the Sandwich Islands and other localities. On our eastern seaboard, it is very abundant, from Victoria to at least as high up as Central Queensland. In New South Wales, Queensland and Victoria, many thousands of baskets of this fish are disposed of as food, annually. During a recent year in New South Wales alone nearly 45,000 baskets of Mullet-principally Sea Mullet-were received for disposal at the various Fish Markets. The average basket of Mullet contains about 75 pounds weight; and, if we calculate the fish at an average of one pound weight each, we find that we have the imposing total of $3,375,000$ individuals. In addition to these, of course large numbers were disposed of at various centres and in country districts, without ever having passed through any recognised market. These would greatly augment the numbers given. I furnish the foregoing statistics with a view of showing the reader wh:t a valuable asset is this fish and of giving some idea as to its potentialities.

This species inhabits in great abundance the muddy bottons of all the harbours, and lakes, and the lower parts of all the rivers lying within the area of its habitat; even occurring-to a lesser extent-in the fresh-water portions of many of the coastal rivers in New South Wales.

It is unfortunate that such an important food-fish as this, should be known in the two principal and neighbouring States, by different names. In Victoria it is known as "Sand Mullet," a name which we, in New South Wales, more judiciously apply to the Mullet which is also known as Tallegalane or Lano (Myxus elongatus). As in a number of other fishes, so in this, various names are applied at different stages of growth. In New South Wales, the young up to about 8 inches in length ( 2 years old) are often termed "Bully"-o: "River"-Mullet: above this size 
and up to about I4 or I 5 inches, being called "Hardgut." The name "Hardgut-Mullet" is also made to apply in many cases to all, from the smallest size up to that just mentioned; while "Sea Mullet" is the generally-accepted name for the adult. Notwithstanding what has been written in the past, there are still some who are under the false impression that the Sea Mullet and the Hardgut-Mullet are distinct species. For convenience sake it is often desirable to make use of the latter term when speaking of the young, and there can be no harm in so doing provided that their true specific identity is always borne in mind. Along the coast of Queensland "Hardgut" are known as "Mangrove-Mullet."

Up to the size of maturity, this species is a constant dweller in the lakes, harbours and rivers ; ${ }^{*}$ but, after maturity has been reached, each year there is a migration seawards; and, after the sea is reached-on our eastern and western coasts-northward. This migration is solely in connection with spawning operations and takes place about May, June and July. The reason of this movement in a northerly direction, which has been so much noticed along the New South Wales coast and about which so many curious and wonderful stories have been woven, is as follows:-The egg of the Sea Mullet is a free-floating or pelagic one. That being so, if the shoals of Mullet were simply to go straight out of, say, Port Jackson, and there deposit their eggs, the latter would be swept slowly along towards the south while the development of the embryo was in progress; and, as there would be no corresponding northward movement of the young Mullet, the habitat of the species would be gradually-generation after generation-moved farther and farther south until it would disappear altogether from the coasts of Australia. As it is, with the present northward migration of the parent Mullet at the spawning time, it is not improbable that many of the baby Mullet find their way into the waters that their parents have recently vacated. In addition to this, of course, it is highly probable that a large number of the eggs are spawned within, or very near to,

* Instances are on record in which shoals of Hardgut Mullet have been found at sea; but these are extraordinary case brought about usually hy exceptional local conditions. 
the mouths of the inlets ont of the reach of the main southerly current. In connection with this, I might here mention that, on the coast of New Sonth Wales there is generally a slight "northerly set," close inshore; this, at times, becomes quite strong; chiefly in prolonged southerly weather, and it must assist in a measure, in counteracting the influence of the southerly current.

I would ask the reader to pay particular attention to what is here written in regard to the spawning and the migrations of the Sea Mullet, as the same remarks mighr, with certain necessary modifications, be applied to a number of other species.

The Sea Mullet attains maturity at the age of + years, males then being about 15 or I6 inches in length: while the females measure about 18 inches. As in many other fishes, females of equal age with males, are a good deal larger than the latter.

This fish grows to a weight of over Io pounds, with a length of nearly 30 inches. 'The largest examples usually come from the various lakes and small lagoons along the New South Wales coast.

In regard to the reproductive power of the Sea Mullet, I might state that the ripe roe of an ordinary large femaie contains an enormous number of eggs; probably considerably over a million.

As a great deal of confusion exists in the popular mind in regard to the identity of our Mullets, the following points will be found of use. The Sea Mullet may be at once distinguished from any of the others mentioned herein, by the fact that it has a thick, transparent, fleshy lid surrounding and almost completely covering the eye; and, also, that there are from 40 to 42 transverse rows of scales along the borly from the operculum to the root of the tail.

The colours are as follows: Steel blue, with a tinge of green or olive, above; sides and lower surfaces silvery. There is a small black spot at the root of the pectoral fin and a golden spot-diffused on the edges-on the upper angle of the operculum. The dorsal and pectoral fins are a dark bluish-grey, while the caudal and anal fins are yellowishgreen. 
The Flat-tail Mullet cannot claim anything like the commercial importance of the previously-mentioned species, nor does it grow to a very large size; still, it must not be despised, as it must always merit a prominent place amongst the fishes which are used as food.

It occurs very rarely on the coast of Victoria, gradually increasing in numbers as we travel northward along New South Wales and the greater part of Queensland. Like the Sea Mullet, it inhabits all the inlets; but unlike that species, does not proceed far in the direction of fresh-water. It usually also, prefers less muddy ground.

This species may be captured by means of hook and line-a worm or dough-bait being used; while the adult Sea Mullet seldom or never is. I have often captured the young Sea Mullet with a dough-bait, using a cork for a float

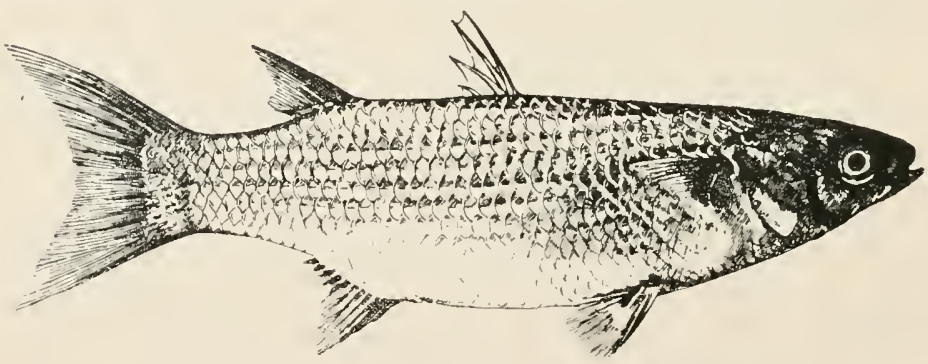

F'ig. 28.-Flat-taIl Muleet (Mugil peronii).

and allowing 6 inches of the line to hang down into the water.

In Queensland this species is known as "Tiger" or "Tygum" Mullet; the last name being an aboriginal title.

Like the Sea Mullet, the Flat-tail Mullet reproduces by means of a pelagic egg, but this being deposited at or within the mouths of the inlets, there is no necessity for, nor do we find, any northward spawning migration. The spawning takes place during or about the months of February, March and April.

The Flat-tail Mullet grows exceptionally, to a length of nearly i 8 inches, with a weight of 2 pounds. The usual length of those marketed is from about Io to 12 inches.

This Mullet has no fleshy eyelid, and the scales are 
larger and consequently less numerous than those of the Sea-Mullet, there being from 35 to $3^{8}$ transverse rows from the head to the foot of the tail.

The colours are as follows:-Steel-blue above, silvery on the sides, white below. The scales of the back and sides have each a narrow longitudinal streak along the middle, forming bands; often with golden reflections. There is a small black spot at the root of the pectoral fin, preceded by a bright golden blotch. The second-dorsal, anal, and caudal fins are tinged with gold on their outer margins.

The Diamond-scaled Mullet: This species is notable for its very large scales and its broad, flat head. It is captured in some abundance along the central and northern portions of the coast of Queensland; being less common farther south, and exceedingly rare in the north of New South Wales. The species is distributed throughout the Seas of India and the Malay Archipelago, and probably is to be found along portions of the northern coastline of Australia.

It attains a weight of several pounds and is of a pretty silvery colour, each scale being very prettily-margined with black.

The Sand Mullet: Of the three common commercial species of Mullet in New South Wales this is the least valuable.

Its distribution along our coastline is very similar to that of the Flat-tail Mullet,* with which it agrees somewhat in habit.

It grows, exceptionally, to a length of about I 5 inches, the average size being very much smaller.

Like the two preceding species, it has no fleshy eyelid. There are about 45 rows of scales along the body, which is considerably more elongate than that of the Flat-tail Mullet.

In clear water its colours are very similar to those of the Flat-tail Mullet; but the golden spot on the upper half of the operculum is not so distinct; being more diffused.

The Yellow-eye Mullet: This fish is distributed riglst round the southern half of Australia from about

* It has been recorderl frou Westeru Australia. 
Newcastle, in New South Wales, to at least the same latitude in Western Australia, occurring also commonly in Tasmania and New Zealand. In Victoria and Tasmania it is considered to be of considerable importance: chiefly because of its abundance. It has not the edible value of the Sea Mullet.

To a great extent this species frequents sandy ground, living upon the organisms contained in the sand. It is quite commonly obtained by means of hook and line.

In Victoria, this Mullet is known as "Sea-Mullet"; a most unfortunate circumstance, when the great difference between it and that species, is taken into account.

In Western Australia, it is usually called "Swan-River Herring," which is still more unfortunate, as there is nothing of the Herring about this fish.

This species attains about the same size as the Flat-tail Mullet.

There is no fleshy lid to the eye, and the scales are very small; there being about 60 rows along the body.

In colour it is steel-blue on the back, the sides being silvery-white and the belly whitish. The iris of each eye is of a pretty orange-yellow tint, whence the common name which I have applied to it.

\section{THREADFINS OR TASSEL-FISHES.}

(Family: Polynemida.)

THIs family comprises numerous species of tropical fishes, chiefly characterised by the presence of long filaments, which are used as organs of touch, situated near to the pectoral fins. They are coastal fishes, the majority of them entering brackish, or even fresh, water. The body is rather compressed, and is covered with smooth or fairly-smooth scales. The snout is prominent, projecting beyond the mouth. The lcng pectoral filaments may be moved quite independently of the fins. They vary in number in different species; ranging from 3 in some to as many as $I_{4}$ in others. So finely 
drawn-ont are they in sone species, that they are as much as twice the length of the fish itself: while in others, they are not longer (and sometimes they are even shorter) than the pectoral fin itself. Günther in speaking of the Tasselfishes says: "It is evident from the whole organisation of these fishes, that they live on a muddy bottom* or in thick water, such as is found near the mouths of great rivers. Their eyes are large, but generaily obscured by a filmy skin, so that those feelers must be of great use to them in finding their way and their food."

Some of these Tassel-fishes reach a length of + feet: and are useful as food or for the isinglass to be obtained from their air-bladders or "sounds," as in the case of the Jewfish family (page II3).

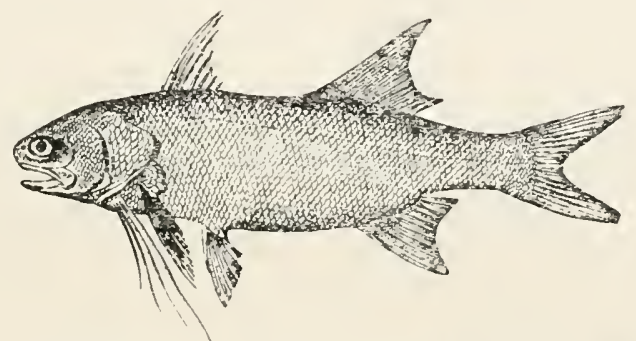

Fig. 29.-Cooktown "SAlason" (Polynemus tetradactylus).

On the coast of Queensland there is a fislo known as the "Cooktown Salmon" (Polynemus tetradactylus) which is a member of the family under discussion. In this species the four free pectoral rays are quite short. It has earned its very unsuitable common name, according to Saville-Kent, "on account of its external shape and the pin! tint of its flesh when cooked." This fish is taken plentifully in the estuary of the Endeavour River; examples averaging commonly Io to I 2 pounds in weight. It is founsl also in India, the Malay Archipelago. China, etc.; in India attaining - according to Day-a length of 6 feet and upwards. Another species occurring in Queensland waters, is Polynemus sheridani; which is stated to grow to the great weight of one hundred pounds. Amongst others, two species which

\footnotetext{
* Some species are found min samly bottoms.
} 
occur on the coast of Queensland are also found in New South Wales. One of these, known as the Blind Tassel - Fish (Polynemus macrochir), is so-called because of the fact that the eyes, though normally developed, are covered by a dense filmy skin. The loss of vision thereby occasioned is compensated for, by the highly-specialised. long, tactile rays, developed in connection with the pectoral fins.

\section{THE PIKE FAMILY.}

(Family: Sphyranider.)

T'ne fishes of this family are camivorous and highly voracious. They embrace about 20 species; the mouths of ail of which are provided with dangerous-looking teeth. In size, they vary from some of about a foot in length, up to the enormous Barracuda (not the Barracouta) of the West Indies, which reaches a length of 8 feet, and is a menace to bathers. Though they are nearly all used as food, some of the tropical species are said to be of a poisonous nature.

The Pike family is well represented in Australian waters. The most important species is the Shortfinned* Pike (Sphyrana nor chollandice), which is found

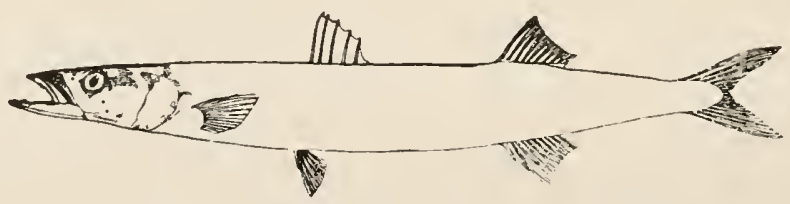

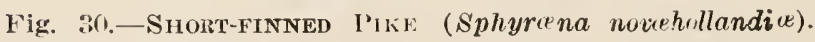

along the coasts of New South Wales and Victoria. It is in its greatest abundance on the Victorian coast. In the fish-markets of Sydney it is to be seen in small num-

*Called "Short-finned" to differentiate it from the "Long-finned" Pike, a fish of another family (see page 106), and with which it is often ronghly classified by fishermen and others as simply "Pike." 
bers all the year round. Though of fairly-good flavour, this fish is not in much demand as a food product.

The teeth are very formidable. There are 2 to 4 pairs of strong, recurved, conical teeth, in the upper jaw towards the front; behind which, on each side, is a single, closelyset row of minute ones. Then there is a pair of strong recurved fangs in the middle of the lower jaw, at the front, followed by a row of conical teeth, numbering about 16 , on each side and strongest towards the back of the mouth. In addition to these, there are strong and sharp teeth (palatine teeth) along the centre of the upper jaw.

In colour this species is greenish above and silvery below; the second dorsal and caudal fins being yellowish.

The Short-finned Pike usually attains a length of 2 to 3 feet: specimens of a larger size being very uncommon.

Several other species of Sphyrena inhabit the seas of Australia. 


\section{Chapter $V$.}

Cuvier's Square-Tail-The Whario Family-The Grenadiers or Whiptails-The Cod Family-The Nannygai Family-Knight FishesBull's-Eyes-Centrarchoid Fishes-The Blackfish Family-The Tripletails-Rifle Fishes-The Perch Family.

\section{CUVIER'S SQUARE-TAIL.}

(Family: Tetragonurider.)

THE sole member of this family, is that peculiar fish, known sometimes as Cuvier's Square - tail (Tetragonurus curieri). It is a widely-distributed oceanic species, but is not often obtained. It is known from the Mediterranean Sea, the neighbouring parts of the Atlantic Ocean, and also, the South Pacific Ocean, including the eastern coast of Arstralia. "It is said to descend to great depths at certain seasons, and to feed on Medusæ; its flesh is poisonous."(Boulenger.) It attains a length of 18 inches. Very little is known in regard to the habits of this species. When young it seeks the shelter of the umbrellas of certain Medusæ.

\section{THE WHARIO FAMILY.}

(Family: Stromatcide.)

'THIs family consists of marine fishes, pelagic and deep-sea. feeding on Crustaceans, Medusæ, or the fry of other fishes. About 45 species are known, but very few of them are of economic value. Probably the most valuable is Scriolella brama, which is found on a portion of the eastern coast of Australia, as well as in New Zealand, where it is known as Whario or Warehou. Large numbers of this species are 
captured in New Zealand, many being despatched to the principal Australian centres of distribution-notably Sydney -in either a frozen or smoked condition. On the Victorian coast, where it is often obtained, this fish is usually known as "Trevally," a name which should only be applied to Caranx.x georgianus (page 149 ).

Perhaps the most remarkable fish in this family is that peculiar form known as the Portuguese Man-o' War Fish (Nomens gronozii). This widely-distributed species, is found on the coast of New South Wales at the same time of the year as, and in the company of, the beautiful, but rather treacherous little Medusa known as "Portuguese Man-o'War" or Physalia. The Medusæ float along at the surface of the ocean, and beneath their long tentacles swim serenely these little fishes, which do not seem to be in any way affected by their proximity to their dangerously-stinging neighbour; while other fishes usually become entangled and paralysed in the embrace of those same tentacles. The Portuguese Man-o'-War Fish has enormous ventral fins, folding in a groove in the lower part of the body.

\section{THE GRENADIERS OR WHIPTAILS.}

(Family: Macruride.)

This is a large family of deep-sea fishes with very large saucer-eyes and having a comparatively short, deep trunk. with an elongate tail tapering to a point. There is no caudal fin.

Fishes of this family have been obtained at a depth of more than 2,500 fathoms.

One species-Macrurus australis-has been obtained in the waters of Tasmania. This curious fish has a projecting snout and an exceedingly large eye, the diameter of whicl is nearly equal to one-third of the length of the head. The head is rather compressed, and possesses a number of rough. obtuse ridges. The snout has a ridge along the middle of 
its upper surface. The whole head is covered with small plates, the surfaces of which are provided with small spines.

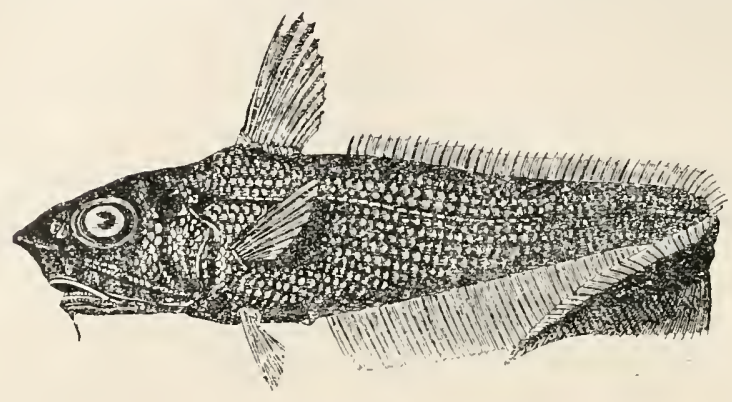

Fig. 31.-Macrurus uustrulis.

Little is known of the distribution of this fish.

A species allied to the above, known as Coryphenoides variabilis, was obtained from the waters South of Australia by the "Challenger" at a depth of over 2,00o fathoms; while two other species of the same genus have been described from our waters, one being from South Australia and the other from Tasmania.

\section{THE COD FAMILY.}

(Family: Gadida.)

THE Cod family, which is so well represented in the waters of northern climes, and which is of such great importance to mankind, is comparatively unimportant so far as our Australian waters are concerned. Still, it contains several species of economic value: The most important being the Beardie or Ling (Lotella callarias) and the Red Cod (Physiculus bachus).

The Beardie is fairly common along parts of the New South Wales coast, and is also found on the coasts of Victoria and Tasmania. It is a small-scaled species, of a rich chestnut-brown, on the upper parts, being lighter on 
the lower surface. It attains a length of about 18 inches. There is a small barbel on the chin of this fish.

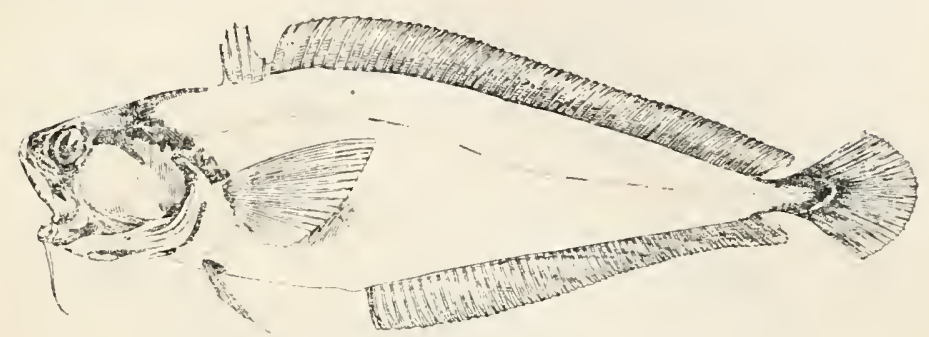

Fig. :;-- Rentan: (Lotella callarias).

The Beardie is usually captured by hook and line on outside grounds, in the vicinity of rocky reefs and "bomboras," though it is also to be obtained in the lower parts of our harbours. It is usually considered to be of fair value as an edible fish.

The Red-Cod is somewhat similar to the preceding. but it attains a larger size, and, with the exception of the lower parts, is of a uniform reddish or reddish-brown tinge. Upon a close examination being made many other differences between the two species are apparent. These need not be mentioned here.

This species is not common on the New South Wales coast, though it is found along the southern portion. It occurs more commonly on the coasts of Victoria and Tasmania and also New Zealand, where it is esteemed as foorl.

\section{THE NANNYGAI FAMILY.}

(Family: Berycida.)

THE only representative of economic importance in our waters, of this very interesting family, is that beautifullooking and familiar fish linown as the Nannygai (Bery.x affinis). In colour, this lovely fish is of a most brilliant, uniform golden-red, "shnt" with vinlet: and this, taken 
together with its large and handsome saucer-like eyes and deeply-forked tail, render it the most conspicuous object in the fishmonger's window. Its very large, deeply-slanting mouth also calls for some mention. The sculpturing of the scales-which in this species are ctenoid-is very remarkable. A small body-scale makes a most interesting and beautiful object for the microscope.

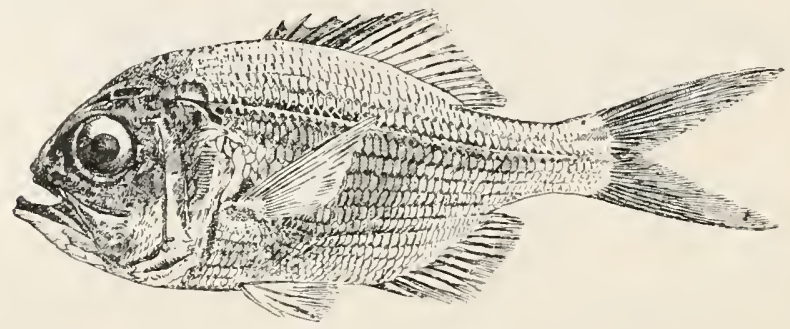

Fig. 33.-NANNiGar (Beryle uffinis).

The Nannygai usually occurs in fairly deep water, wide off-shore, at sea; in the neighbourhood of sunken reefs and rocky bottoms; and, in such localities, it is, at certain times, quite plentiful, being captured with hook and line. It takes a flesh-bait very readily. It has been taken in water of a depth of 80 fathoms, while young examples are often taken in shallow water in the harbours. As a food-fish it is generally considered to be of the first importance, and it always finds a very ready sale, at a high price, in the markets. Many people regard it from the epicurean point of view as a very great delicacy; this idea being, no doubt, greatly assisted by the generally-beautiful appearance of the fish when fresh. The Nannygai is found over the greater portion of the coasts of New Sonth Wales, Victoria, and parts of Tasmania. It also occurs in New Zealand, and commonly attains a length of about is inches.

Other species of the genus Beryx-to which the Nannygai belongs-are found in moderate ocean depths in the Indian Ocean, on the coasts of Japan, Cuba and Madeira, and also in the Gulf Stream. These fishes are particularly interesting, as they represent at this day, certain fossil forms of Teleostean (or bony) fishes, which are amongst the oldestknown-geologically speaking. 
To this family also belongs the curious little fish known as the Roughy (Trachichthy's australis). 'This inhabits very similar situations to those in which the Nannygai is found, viz., rocky bottoms and bomboras, where it may be captured occasionally, either by hook and line or by means of the trammel-net. It is also sometimes taken in the lobster-pots, but never in any abundance. The peculiar rough bodywhence its name-is of a deep reddish-brown, the fins being yellow and black. When fresh it has a most pleasing appearance, though very curious-looking. Iike the Nannygai, the Roughy has large eyes to enable it to see well in the deep water that it usually frequents, and where the light is reduced to a kind of twilight.

\section{KNIGHT-FISHES.}

(Family: Monocentride.)

ONLY two species of these very remarkable Knight-Fishes are known to exist: and one of these. known as the Aus-

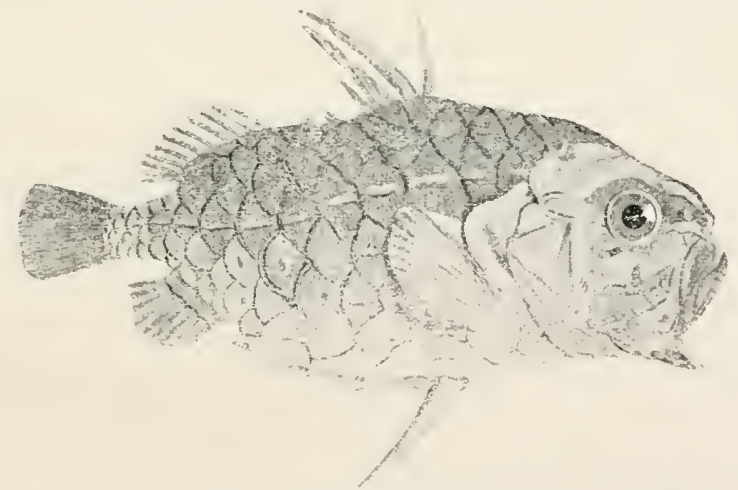

Fig. 34.-KNight-Fisu (Momorntris japonicus).

tralian Knight - Fish* (Monocentris gloria-maris), is found on the coast of New South Wales and Queensland.

*Not having a specimen of this speries at hand, I have given an illustration of the elosely allied Japanese species (Monocentris japonicus) which will probally be found to occur on portions of the Australian coast. 
It is indeed a quaint-looking creature, as it is clad in id strong coat of mail, formed by the large bony scales. Instead of the ventral fin, there are two enormonsly-developed ventral spines. On each side of the head near the mouth are peculiar luminous discs, which are probably of service to the fish in assisting it to obtain its food. Though this fish is not often obtained, it is most probably not uncommon on our coast. Its ordinary habit of life is not likely to lead it often either into the scope of the fisherman's net, or, to take a bait. Examples are occasionally thrown up on ocean beaches with dèbris, after a storm.

The Australian Knight-Fish reaches a length of 9 inches.

\section{BULL'S-EYES.}

\section{(Family: Pempheride.)}

'Two species of fishes known as Bull's-eyes occur on the eastern coast of Australia; the Small-scaled Bull'seye (Pempheris compressus) and the Large-scaled Bull'seye (Pempheris macrolcpis). Both of these are found on the coast of New South Wales; the former being the more common kind. Their most noticeable characteristics are: a deep, highly-compressed, short body; a short dorsal fin, a very long anal fin and exceedingly large saucereyes like the Nannygai, but relatively larger. This lastmentioned feature is responsible for the common name of Bull's-eye. The small-scaled species is of a light-brown colour, clouded over, particularly on the upper parts, with fine dots of a darker hue; the fins being also darker. The Large-scaled Bull's-eye in addition to the greater size of the body-scales, is further characterised by possessing lightcoloured longitudinal lines, between each row of scales, on the hody. In life, it is of a rich reddish-brown colour. Neither species attains to a large size, the average being about 8 to 9 inches; and, as they are never captured in numbers, they cannot be said to be of much value from an economic standpoint. 


\section{CENTRARCHOID FISHES.}

(Fanily: (cutrarclida.)

'T'us family, which is represented in America by so many species, and which includes in its numbers the famous "Basses" of America, has only one representative, so far as is known at present, in our waters. This is the Flag-tail (Kuhlia temiura). It is very rarely seen.

\section{THP BLACKFISH FAMILY.}

(Family: K'yphosida.)

Such well-known fishes as the Blackfish (Girclla tricus. pidata), the Bluefish (Girella cyanca), and the Drummer (Kyphosus sydneyanus) are included in this family, in addition to a number of others.

The Blackfish is one of the best-known fishes of Eastern Australia, particularly on the coast of New South Wales. Though its flesh is not of the delicate flavour possessed hy many of our fishes, still it may be truthfully stated to be one of our most important food-fishes; as it is one of the "stock" fishes of our markets, being always present in greater or lesser numbers. It is also found on the coasts of Queensland, Victoria, Tasmania, and possibly South Australia and West Australia. In Victoria, it is known as "Black Perch" or "Rock Perch," and in Tasmania as "Black Bream"; this being another instance of the necessity for the adoption of uniform common names in cases where the same species is found in various States.

This Blackfish must not be confused with the so-ralled "River Blackfish," which is a fresh-water fish, and has no affinity with the one under discussion, as it is one of the Blenny family. (It will be referred to later on.)

The Blackfish is a herbivorous fish, subsisting upon "sea-grass" and "sea-moss." The former it obtains upon the flats in the shallow water of our coastal lakes and 
estuaries; and the latter is that hairy-looking light-green seaweed commonly found growing around rocks, piles and floating timber. This weed is the usual bait employed in fishing for this species with hook and line.

Though this fish has a somewhat dingy-looking appearance some time after being caught-as it appears in the fish-shops, for instance-still, when it is quite fresh, it is really a handsome species, being generally of a silvery-grey, with a number of dark-brown vertical bands. These bands are particularly prominent in young Blackfish. In examples of this species whicl have inhabited dark, muddy waters for any length of time, or certain coastal lakes which have for a time been cut off from connection with the sea, these vertical bands become almost, or completely, lost, and the fish is then of a brownish or blackish hue, being a little lighter on the lower surface. Like many of our estuarine fishes, this species is able to exist in waters that are almost free from any trace of salinity.

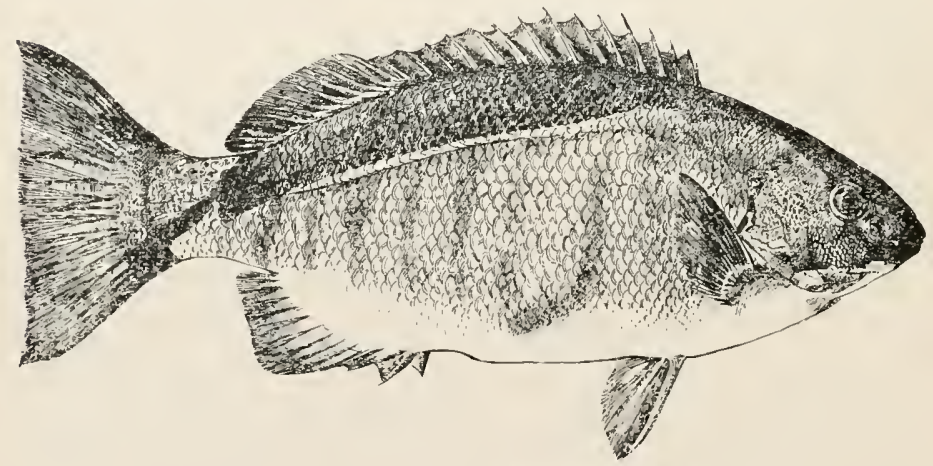

Fig. 35.-BuackFsu (Girdll tricuspidata).

Though this fish is a true vegetable-feeder, as indicated by the peculiar structure of its teeth, and the great bulk of its digestive organs, young examples will take an animal bait quite freely.

The Blackfish when hooked is a great "fighter," and is rightly looked upon by the angling portion of our population as one of our best sporting fishes.

The average weight of the adult Blackfish usually obtained varies from I pound to 2 pounds, but examples 
of 5 pounds weight and cven more have been captured.

The Bluefish is somewhat similar in form to the Blackfish, but is more elongate, and possesses a much larger and more powerful tail, as befits its ocean existence. It loes not appear to be at all common on the coast of New South Wales, and is not known to occur anywhere else in Australia, though it is very common at Lord Howe Island. It is verv seldom seen in our fish-markets.

In colour, it is of a magnificent uniform cerulean bhe, with a golden sheen, and with numerous golden-yellow spots over the body. The blue colour fades very quickly after death.

To a large extent the Bluefish is herbivorous, subsisting chiefly (in our waters, at least) upon gelatinous seaweeds: but it also partakes to some extent of animal food in the shape of small fishes, crustaceans, etc.. which it finds around the rocky parts that form its home.

It may be occasionally taken with hook and line by using a "Blackfish bait." Specimens are occasionally captured off the point at the entrance to Port Jackson known as "Bluefish," and it appears highly probal,ly that the name of the point was derived from this fact.

The Bluefish reaches a length of over 2 feet, but the average size of those usually taken is considerably less.

The Drummer differs a good deal in shape from both of the preceding members of this family, being much rounder, and, consequently, length for length, a good deal heavicr. So far it is only known from the coast of New South IVales. It is a herbivorous fish dwelling in rocky localities, where it may be captured by means of the trammel net, or occasionally by hook-and-line. At times large shoals of this species move along our shores, and then come within the range of the hauling net; but they are not welcomed by the fishermen, as, on account of their inferior flavour, they are at present almost unsaleable.

The colour of the Drummer is a dark grey, washed with silver on the lower part of the sides, and darker along the back and on the fins. In large examples there are many longitudinal stripes of a dusky, yellowish-golden hue along 
the sides of the body. There is a peculiar knobby protuberance on the head in front of, and between, the eyes.

The 1)rummer grows to a length of more than 2 feet.

\section{THE TRIPLETAILS.}

(Family: Lobotida.)

THIS family contains 2 or 3 species which are large fishes closely allied to the true Perches. They are represented in our watcrs by one species, known as the Dusky Perch (Lobotes surinamensis). Comparatively little is known in regard to the habits of this fish. It has a very wide geographical distribution, being found on the coast of America, in the Mediterranean Sea, the seas of India, China and the Malay Archipelago. In Australia, it has only so far been recorded from Queensland and New South Wales; being a little more common in the northern State.

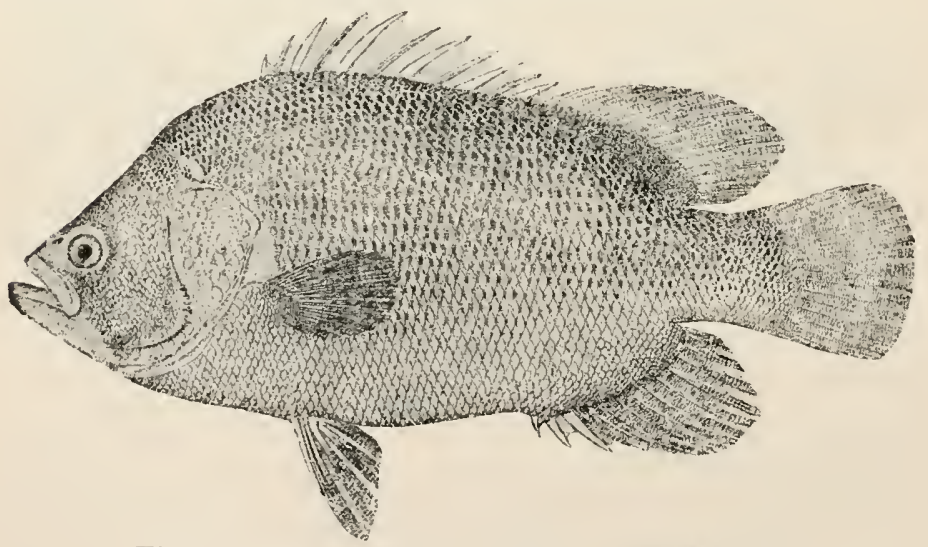

Fig. 36.-Dusкy Perci (Lobotes surinamensis).

In colour, it is of a uniform dark-brown, with the exception of the lower surface, which is lighter.

The Dusky Perch reaches a length of 3 to 4 feet and a weight of 25 to 30 pounds. 
In America, it is known by the names of "Flasher" and "Tripletail"; the last being in reference to the slight appearance as of three tails, which it possesses, due to the greatly-enlarged soft portions of the anal and dorsal fins.

\section{RIFLE-FISHES.}

(Family: Torotide.)

UNE species of this family is found on the coast of Queensland, where it is known by the name of Rifle - Fish (Toxotes jaculator). It has earned this name from its most remarkable habit of capturing insects that are flying near the surface of the water, by shooting drops of water at them. It has a most unerring aim. The Malays who call it "Ikan sumpit" keep it in a howl, in order to witness this singular habit, which it continnes eveil in captivity.

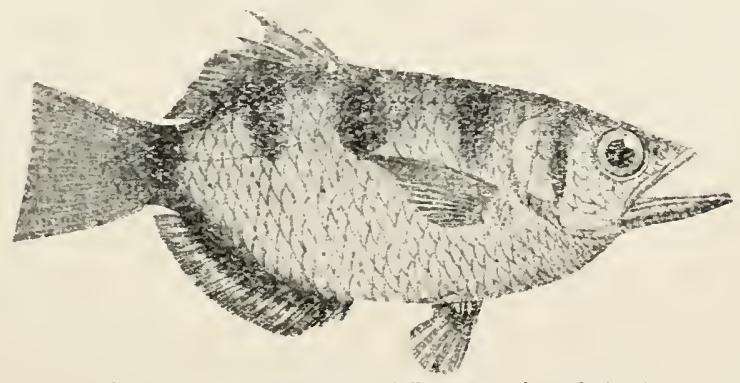

Fig. 37.-RIFLE-FrSh (Toxotes jaculator).

Such a peculiar habit as this, is really most wonderful, and gives us something to ponder over; as it has to be remembered, that owing to refraction, the insect when on the wing, will appear to the fish in the water, to be in quite a different position to that in which it really is; the accuracy of the fish's aim, is then all the more to be wondered at. In addition to its occurrence on our northern coastline, it is also found in the seas of India and the Malay Archipelago. 


\title{
THE PERCH FAMILY.
}

\author{
(Fanily: Serranide.)
}

THIs is one of the most important families of Australian fishes, as it contains many valuable food-fishes. Nearly all are marine, but a few are found in fresh-water. As it will be impossible here, to mention in detail even half of the number, I will have to content myself with a review of the principal ones. These are as follows:-The Estuary Perch (Percalates colonorum), the Fresh-water Perch (Percalates fluviatilis), the Golden Perch or Yellow-belly (Plectroplites ambiguns), Macquarie's Perch (Macquaria anstralasica), the Murray Cod (Oligorus macquariensis), the Wirrah (Acanthistius serratus), the Black Rock-Cod (Epinephelus dremelii); the Queensland Groper (Promicrops itaiara); the Giant Perch (Lates calcarifer); the Pearl Perch (Glaucosoma scapulare); the Old Wife (Enoplosus ammatus), and the Long-finned Pike (Dinolestes lewini). Amongst the smaller species of the family is the interesting little Soldier-Fish (Apogon fasciatus).

The Estuary Perch is a familiar object to most people, in the States of New South Wales and Victoria at least, as a few are generally to be seen amongst the fish in every fishmonger's stall. Particularly is this so after heavy freshets in our coastal rivers, and during the winter months. After heavy rains have fallen on the watersherl of say, one of the coastal rivers, there is in a short time a superabundance of fresh-water, heavily charged with silt and often decayed vegetable matter in the tidal portions of the river; and this has the effect of driving out to the lower and clearer estuarine or harbour waters, most of the inhabitants, chief amongst which are the Estuary Perch. As there are then very many more fish in a given area than previously, the fisherman is enabled to reap a richer harvest with his meshing-nets and hauling-nets. The same applies in the winter time, when these fishes come down of their own free will to the open waters for the purpose of spawning.

The Estuary Perch is common along the Australian 
coast, from about Morcton Bay in Queensland to at least the Murray River in South Australia; and is also found in Tasmania. In Victoria it is particularly abundant in the Gippsland Lakes, and from that, it is often known there as "Crippsland Perch."

It attains a weight of about 5 pounds, but examples of that size are uncommon, the more usual size as seen in the markets, varying from about 12 ounces to 2 pounds.

It will be noticed that I have here used for this fish the term "Estuary Perch." My reason for so doing, is, that there is another perch, very closely allied to this. which is found in the fresh-water portions of somc of our coastal rivers, all the year round, and even in pools removed from the rivers. (It may also be found in brackish water.) It is most probable that it even spawns in the fresh-water. 'This form is to be distinguished from the Estuary Perch by its more elongate body which has a fairly elliptical outline, while in the latter the profile of the back is quite gibbous or humped. These are differences which, though varying within slight bounds, are still quite constant. Differences in colour are also apparent: what may be properly termed the "fresh-water" form, being usually more dusky than the other, and possessing a large black blotch on the central portion of the anal fin, the latter being comparativeiv indistinct in the Estuary Perch. In 110 previous work dealing with our fishes has there been any mention of this Percl as a distinct species; that is why I now take such pains to point out its general features.

I have, quite recently, proposed for this fish, the title of Fresh-water Perch and have described it under the name of Percalates flusiatilis.* Of course other freshwater Perches of a totally different nature (and belonging to other gencra) are also known to us, but where these exist, they are usually given some specific prefix-such as Silier Perch, Macquarie's Perch, etc.

The Golden Perch or "Yellow-belly": This highlyimportant and valuable fish is abundant in all the western

* Throngh unforeseen circumstances the Paper in which I have described this species has not yet appeared in print; reference to the species will, however, be found in a Note communicaterl to the Limnean Society of New South Wales in May, 1906. 
rivers of New South Wales: including the Darling and the Murray; and has also been taken in the Mary River, Queensland. It is pre-eminently what might be called a "still-water" fish, being very abundant in lagoons and "billabongs." It is also a "mid-water" fish; that is, it swims at some distance from the bottom usually; this habit being different to that of the Murray Cod for instance, which, while inhabiting the same waters, usually gropes about in the vicinity of the bottom. It is a fish of the plains, rather than one of the mountains.

As an article of food, the Golden Perch is very well and favourably known, both in the western areas and the cities of Sydney and Melbourne.

Though taken by hook and line, the usual method of capture is by means of a short meshing-net (gill-net) which is set at night, across the billabong or lagoon. A fisherman who has fished for Yellow-belly in many of the New South Wales rivers, tells me that one of this species will blunder straight into a meshing-net, apparently without seeing it; while a Murray Cod under the same circumstances would swim up to within a short distance of the net and then quickly take fright and "double" back again. The relatively different positions of the eyes in each species, would partially account for this difference in habit.

The name of "Golden Perch" also that of "Yellowbelly" are both derived from the fact that when this fish is alive, or just freshly-caught, the sides and lower portions are of a beantiful orange-gold colour.

This fish often attains a weight of 7 to 8 pounds.

Here it will be of interest to mention that in I893, Mr. Saville-Kent, the well-known naturalist, transported a number of Golden Perch and some Eels from the lower portion of the Murray River to the upper portion of the swan River in Western Australia; riâ Adelaide; and also, in I894, several hundred Golden Perch averaging from a quarter to half a pound in weight. Some of the latter were placed in the Upper Swan, while the remainder were put into a lake, having a constant supply of water, about Io miles out of Albany. 
It will be of great interest to see what has been the result of this planting.

Macquarie's Perch*: This is another of the fishes of Western New South Wales, though it also occurs in the upper waters of the Nepean River, and probably George's River and Cook's River. It is a valuable fish from an economic standpoint, though not nearly so important as the preceding. It is often known to western folk as "Black Bream," as is likewise, occasionally, the Silver Perch; but neither of them is in any way related to the Black Bream; in fact-and this is a point that is worth remembering-no true Bream inhabits any of our fresh-a'ater ricers, though the term is often heard used in connection with one or other of our fresh-water fishes.

In the upper waters of the Nepean, this species, there very dark in colour, is often known as "Blackfish," which is another misnomer.

Macquarie's Perch attains a length of from 12 to 15 inches.

The Murray Cod: As a food-fish this magnificent species stands second to none. Attaining to such large proportions and being of such good flavour, this excellent fish long ago came prominently forward; and it may be safely said, that the supply is never likely to exceed or even meet

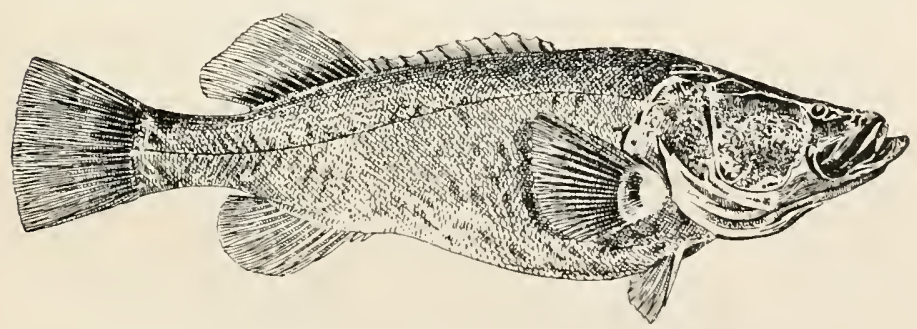

Fig. 38.-Murray Con (Oligorus marequarionsis).

the demand. It inhabits the whole of the immense Murray River system, from the limits of tidal influence in South Australia right up into Queensland. In addition it is found in the head-waters of the Clarence and Richmond Rivers

* This tish is often known as the "Homtain Perch." 
in New South Wales. Years ago it was introduced into the Yarra Yarra River in Victoria, with, apparently, slight success. It was also transplanted to Lake George in New South Wales, where it throve well, and where for many years a lucrative fishery was carried on.

As the capture and disposal of the Murray Cod afford a means of livelihood for a great body of men in New South Wales, Victoria and South Australia it will be of importance to go into a little detail in regard to the means employed and the gear used. The observations which follow are taken from my notes on this subject, published in a pamphlet on the Murray Cod Fisheries in I903 (Department of Fisheries, N.S.W.). Those who desire further information on the point are referred to that publication.

The articles used in capturing the Murray Cod, comprise lines, nets and traps of many descriptions. The Lines include "springers," hand-lines and set-lines.

"Springers" consist of first, stout, flexible, mallee saplings of a length varying from 7 to 20 feet, the most common lengths being from io to 15 feet. The length of the pole depends primarily upon the depth of the river near the bank. Where there is a deep hole near to the bank, only a short pole is necessary. 'To the thin end of this sapling is attached a single strong line, which varies likewise in length according to the depth and current; it appears to be generally from 4 to 5 yards long, but may be 20 feet or more, so as to allow the living bait full play. In many cases, a swivel is attached to the line, near to the mallee, to lessen the liability of the line snapping through the gyrations of either the living bait or the captured "Cod." To this line one or more hooks are attached, according to circumstances. The springer is now complete, and, being ranmed into the bank in such a position that it will overhang the stream, is ready to be baited. Living bait is often used, as that is more attractive to the larger fishes. It is stated that Murray Cod captured by means of the springer are seldom under 20 pounds, and are more often about $5^{\circ}$ pounds, in weight. Occasionally the bait used is a living Colden Perch of as much as 3 pounds in weight, and of course 
onty a very large Murray Cod could take such a "morsel" as this.

Hand-lines both with and without rods are used, principally by amateur fishermen. It is not a mode of fishing much in favour with those who have to depend upon it for a living.

Sct-lines embrace what are termed "side-lines" and "cross-lines." Side-lines are set along the bed of the stream, parallel with the banks and are generally of either manila rope or copper wire, and may be of any length up to a quarter of a mile. On these, short sections of lines called "snoods" are fastened every 3 or \& yards, and to these snoods the hooks are attached. Cross-lines are made on a plan very similar to that followed in the making of the sidelines, excepting that the hooks are closer together and are fastened to snoods about I foot, or more, in length. They are set across the river, creek, or lagoon, as the case may be, and large catches often result from their use.

The bait used is of a most heterogeneous character. As tending to show how impartial the Murray Cod is, I may here state that the following animals or portions of them, are used (in addition to others) :- Rabbits, opossums, birds of many kinds, various species of fishes (including portions of Murray Cod itself), frogs, crayfishes, grubs and even those bétés noires of Murray-Cod fishermen, the turtles. Quite a large trade is carried on in some parts of the Lower Murray with the grub known under the aboriginal name of "Pallety" or "Bardo." This grub is the larval form of one of the wood-boring beetles (Phoracantha). 'They are obtained from the roots of mallee, wattle and native honeysuckle, principally during the months of September, October and November. Fishermen buy them at the rate of about 3s. 6d. per Ioo. "Pallety" seems, from all accounts, to be a tit-bit far too inviting for a Murray Cod to refuse, consequently it is in great request.

The principal kind of net in use is that known as the Drum-net, which, briefly stated, is a large cage having a funnel entrance. To this cage or trap are attached "wings" of varying length, for the purpose of guiding the fishes into the centre. The body-portion or trap-proper is supporterl 
by two (or three) hoops, about 3 feet 9 inches in diameter and about 5 feet apart, making the trap about 5 feet long. The wings may be from 8 feet to 5 feet in length.* These nets are set along the banks in shallow water.

Another net sometimes used for the capture of Murray Cod is that known as the "Trap-net" or "Bag-net." This has a kind of bag or pocket in the centre. In use, it is set with its mouth facing up stream, across a creek or the mouth of a lagoon. It is held open by the current running out as the river falls, catching all fishes trying to regain the main river.

Much more that would be of interest and value might be written in regard to the capture of Murray Cod and of the gear used in the retaining of them alive prior to despatching them to market, but we must now pass on to a further discussion of the members of the Perch family.

The Wirrah is, so far as at present known, a native of the waters of New South Wales and Western Australia, not having been recorded from any other State. (Only one record of its occurrence in Western Australia exists.) Though it attains to fairly-large dimensions, this species is not at present considered of much importance as a foodfish; as the flesh is tough and is not of good flavour. However, examples of a foot or more in length, are often eaten, and are considered by some to be "very fair." As in all other cases in which the flavor of a fish is called in question, so here a great diversity of opinion exists, and I have even heard the taste of Wirrah compared to that of crushed ants. I leave it to the reader to judge for himself.

- When freshly captured the Wirrah has a most beautiful appearance, being of a rich golden greenish-brown. spotted over with numerous, small, round, blue spots; these being on a chocolate ground. Soon after death the colours fade a great deal and the blue color of the spots disappears, leaving only the brown.

It attains to a length of about 20 inches and is a most voracious fish; lurking in dark, quiet nooks and crannies of the rocks and suddenly rushing out upon its victim, which

* In New South Wales 8 feet is the greatest length allowed by Law. 


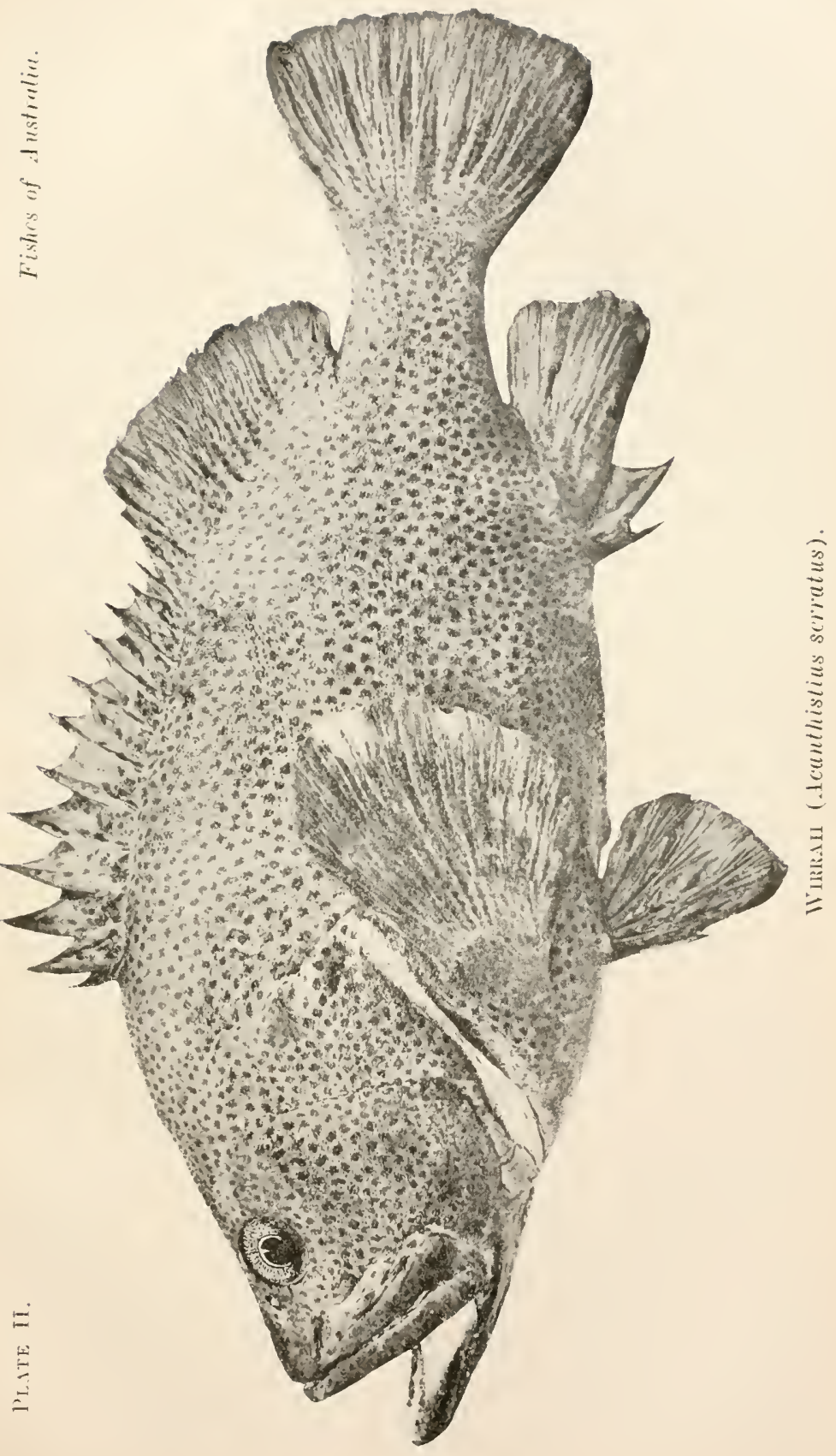



is nsually at once engulfed in the Wrirah's most capacions mouth.

In addition to being occasionally captured "outsidle" on rocky-grounds by hook and line or trammel-net and also in lobster-pots, the Wirrah may be taken at low tide in rocky situations, at the lower parts of the harbours, or on the ocean face, in proximity to submerged rock-crevices: all that is required for its capture, being a strong line, a large hook and a large piece of stont bait. The Wirrah makes stch a violent rush, that often one does not get a chance to see him properly: but there is a swish and a swirl (if it be near the surface) and a violent tug and your fish is hooked. No fine art is necessary ; nor does this greedy fish require tempting baits or semi-invisible "silk-twists."

The name of Wirrah is of native origin. I have heard also the names of "Pepper Cod" and "Peppermint RockCod" applied to this fish.

The Black Rock-Cod is a native of the coast of New South Wales and Queensland and occurs also at Lord Howe Island. This magnificent food-fish attains a large size an!? the flesh is of excellent flavour, particularly that of specimens of a few pounds in weight. Examples of a weight of from 70 to 80 pounds have been taken, but the usual size of those seen in the fish-markets of New South Wales is far below that: specimens weighing 20 pounds being considered large.

The Black Rock-Corl loves to dwell in rocky situations, where it press upon smaller fishes, crustaceans, etc. It is usually captured by hook and line, but occasionally by means of the trammel-net. In colour, this fish is of a uniform, deep, blue-black; young examples being of a lighter hute, with darker vertical bars on the body.

The Queensland Groper: The great fish which is known under this name frequents the coast of Queensland and the northern portions of that of New South Wales. It reaches an immense weight, specimens of from 300 to 400 pounds and probably even more, being known, while it grows to a length of about 6 feet. In the minds of most fishermen and others, this fish is constantly confused with its relatively small relation, the Black Rock-Cod; which we have just dealt with; and any examples of the species which are 
sold in the Sydney Fish Markets are usually offered as "Rock Cod"- the prevalent idea being that they are simply over-grown Black Rock Cod. Of course this idea is quite erroneous, as they not only are distinct specifically, but also belong to different genera; as may have been noticed.

This species has a very great geograplical distribution, being known from New Zealand and both coasts of tropical America, north, to Florida and the Gulf of California and south, to Brazil where it is not tncommon about rocks.

In America it is known as "Spotted Jewfish."

The head of one of this species (from the Clarence River (N.S.W.), weighing 75 pounds, is now in the possession of the Department of Fisheries, New South Wales. The fish from which this was taken weighed 250 pounds.

The Giant Perch: This is another of our great edibla fishes. As far as Australia is concerned, it appears so far to have only been obtained in the waters of Queensland and Western Australia, being best known from the former State. As it is a tropical species, it is more common in the northern parts, where it frequents the lower portions of the rivers. It has a very extensive geographical distribution being found in the seas of India and the Malay Archipelago. It is highly probable that it will be found to occur along the greater part, if not the whole, of the northern coastline of Australia. A closely allied species (Lates niloticus) is fontnd in the waters of the Nile. In parts of Queensland, this species (in common with two other fishes, which are very distinct from one another) is known as "Barrannundi"; but this name properly applied, belongs to the Osteoglossid already mentioned (Scleropages leichhardti, p. 25).

The Criant Perch attains to a weight of 40 to 50 potnds: or perhaps even more.

The Pearl Perch: This handsome and valuable fish is another of our tropical or semi-tropical forms having its principal home in the waters of Queensland. It has been recorded from the waters of Western Australia. In Queensland it is known usually as "Epaulette-Iiish." 'This name is applied to it because of the presence on each shoulder, of a comparatively large, irregularly-oval, bony shield, which is covered with a shining black skin: the bone which forms 
this shield on each side being that known as the supraclaicle. The Pearl Perch is a deep-water fish, apparently frequenting usually deeper water than that in which the Snapper dwells. There is no special fishery established for it, and, usually the only time it is brought to market (in New South Wales at least) is when it is captured by parties (in the vicinity of the northern rivers of New South Wales) out "snappering." It is a pity that the fish is not bronght in more often, as it is a species of great edible value.

In colour, the Pearl Perch is a most beautiful silver with, usually, darker spots on each scale.

It has a very large mouth and prominent "sancereyes" as in most moderately-rleep-water forms. Closely allied species are found in both Japan and Western Anstralia.

In regard to the use of the curious bony epanlettes. apparently nothing definite is known, but it appears to me lighly probable that they are really "lamps," that is, that the black skin which covers them is phosphorescent.

The Pearl Perch reaches a length of about 2 feet.

The old Wife: In this curious fish is to be seen a most wonderful departure from the general Perch shape as it has a deep, highly compressed, and very short borly with very high pointed fins. It is purely an Australian fish and is found principally in the waters of New South Wales and Victoria. To what extent it occurs in the waters of Vestern Australia, whence it has been recorder, is not at present known. How it has obtained its vernacular name of "Old Wife" is hard to guess. Many of the New South Vales fishermen term it "Old Maid" and perhaps in view of the popular idea regarding "old maids" and their prim appearance the application of this name is more justified. In the Melbonrue fish-markets it is often known as "Pastard Dory." Though it is a fine little table fish, it is not often brought to market, as it loes not usually take a bait and seldom comes within the scope of the hauling net, owing to its habit of keeping in the ricinity of rocks and-where these exist-wharves. Large numbers of them are to be seen generally swinming leisurely around the piles of piers and jetties. Tn these localities. they are able to subsist to 
some extent upon the small crustaceans which live amongst the weed.

In colour, this species is of a silvery white or a silvery, yellowish-pink; with eight brownish or black vertical bands; this giving to the fish quite a zebra-like appearance.

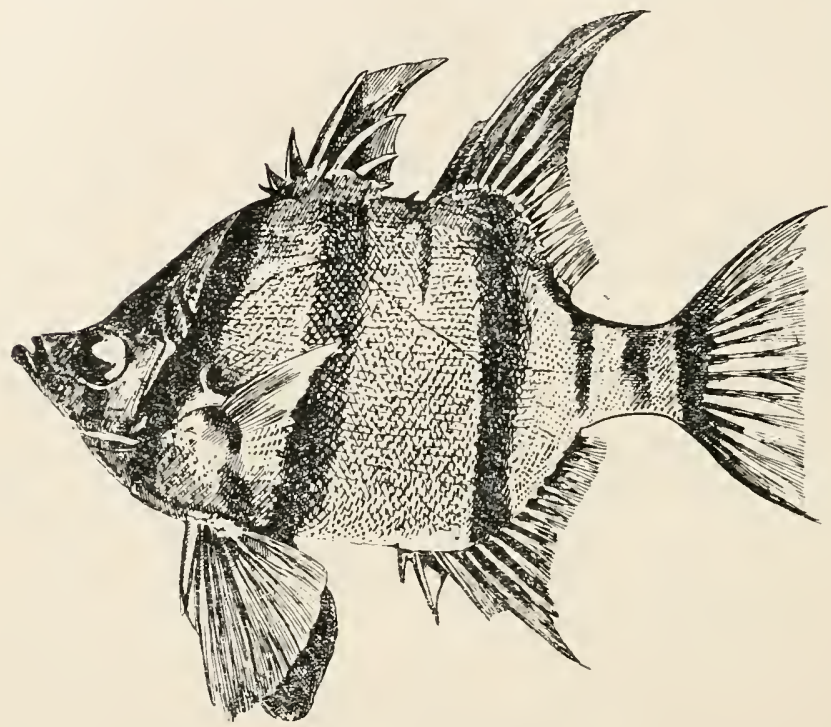

Fig. :39.-OLD WIFe (Fuoplosus armatus).

On account of the remarkable shape of the body ani the narrow snout, this fish was placed amongst the Chretodons (page I35) by the early naturalists including Shaw, who described the species in White's "Voyage to New South Wales" in I790 (Chcetodon armatus, plate xxix., figure i.).

The Long-finned Pike: [In Ogilby's "Edible Fishes of New South Wales" this species will be found grouperl with the Short-finned Pike (Sphyrana noice-hollandia) in the family Sphyrenide and there is still some doubt as to its real systematic position. In placing it amongst the Perches, I am following so eminent an ichthvologist as Dr. G. A. Boulenger, of the British Museum.]

The Long-finned Pike is known to be a native of the waters of New South Wales, Victoria and Tasmania. It is 
more common on the southern portion of the cuastline of the first-mentioned State, and appears to be fairly common in the other States mentioned. Though usually grouped with the Short-finned Pike in the fish markets of New South Wales as simply Pike, there is no difficulty in distinguishin: between the two. In this species, the body is very much deeper and the second dorsal fin is much longer, consisting of about 20 rays as compared with Io in the Short-finnest Pike. The anal fin also is much longer and consists of about 28 rays as against abont $\mathrm{I} I$ in the last-mentioned. Other differences will be at once apparent to even the unpractiserl eye of the ordinary observer: but the points mentioned are quite sufficient for the separation of the two Pikes.

The Long-finned Pike is a very voracious fish and makes great havoc amongst the shoals of smaller fishes, stich as Yellow-tail. In Victorian markets it is known as "Skipjack Pike." It is a good fish for the table.

The general colour of this species is a light yellowishbrown, washed on the sides with silver, darker on the upper surface and lighter below. The fins are of a golden-yellow.

It attains a length of abont 20 inches (this size is the largest I have personally measured).

I mentioned that amongst the smaller kinds of these Perches, was the little Soldier-Fish. This is only a little fellow, commonly reaching a length of 3 to 4 inches. It is a pretty little species with large eyes and rough scales and is very prettily striped along the body-whence its name of "Soldier." It is common on the New Sonth Wales coast-particularly at Port Jackson-and probably occurs on portions of the Victorian and Queensland coasts; though it has not so far been recorded from those places. The original specimens were taken from Port Jackson, and are described in White's "Voyage to New South Wales" before referrerl to. 


\section{Chapter Vi.}

The Pseudochromids-The Band-Fishes-The Knife-jawed Fishes-The Whiting Family-The Jewfish Family-The Silverbellies-The Trumpeters-The Morwong Family-Grunters and Boar-Fishes-The Bream Family--Red Mullets or Goat-Fishes.

\section{THE PSEUDOCHROMIDS}

(Family: Pseudochromidide.)

'TH Is family contains fishes which are closely allied to the Serranid Perches. They are all marine fishes and are mostly of small size, inhabiting the Atlantic, Indian and Pacific Oceans. One of the largest and best-known members of this family is the American "Tile-Fish" which lives upon the bottom of what is called the Gulf-stream Slope, off the coast of New England (U.S.A.), where it was first observerl in 1879. It attains a weight of over 40 pounds.

The Pseudochromid fishes are very poorly representer in Australian waters; one species, called the Leopard-Fish (Gnathypops jacksonicusis) is found on the New South Wales coastline.

\section{THE BAND-FISHES.}

(Family: Cepolide.)

'THERE is only one species of these curious ribbon-like fishes known from Australia, and that is the Australian BandFish (Cepola australis). This was only discovered quite recently, being described by Ogilby in I899 in the "Proceedings of the Linnean Society of New South Wales." The specimen upon which the description was founded was from Port Jackson and is in the possession of the Department of 
KNIFE-JAIVED FISHES.-WHITING FAMILY. 109

Fisheries, New South Wales. The colour of the fisl when alive was a bright red, with some angular yellow bars about the middle of the sides. It meastres a little over Io inches.

\section{THE KNIFE-JAWED FISHES.}

(Family: Hoplognathida.)

'I'HE fishes which constitute this family are specially characterised by the jawbones having a sharp cutting edge so as to form a kind of beak. The body is compressed and deep and is covered with small ctenoid scales. Little is known regarding the habits and distribution of the Australian Knife-jaw (Hoplognathus conwayi).

\section{THE WHITING FAMILY.}

(Family: Sillaginides.)

THIs is a very important family in Australian waters, as it comprises amongst its members, some of the principal foodfishes of several of the States. The most important of these are: the Sand Whiting (Sillago ciliata), the Trumpeter Whiting (Sillago maculata), and the Spotted Whiting (Sillago punctata).

The Sand Whiting is rightly regarded as, if not actually the finest, second to none amongst all the Australian fishes, as a table fish. The flesh is white, firm and flaky, and is easily digestible. For these reasons, this fish always commands good prices in ottr markets; and, whatever may be said of other fishes, there is never a "glut" of Sand Whiting.

It is plentifully distributed over the whole of the New South Wales coastline, the greater part of that of Queens- 
land and to a lesser extent along a portion of the Victoriam coast. In Tasmania it occurs sparingly.

It dwells upon clean, sandy bottoms in all of the harbours within its habitat: as well as the larger coastal lakes and on sandy bottoms in fairly shallow water off the various. ocean-beaches. In these localities it cbtains its food, which. consists chiefly of sand-crustaceans, worms and the little bivalve mollusks known as "pippies."

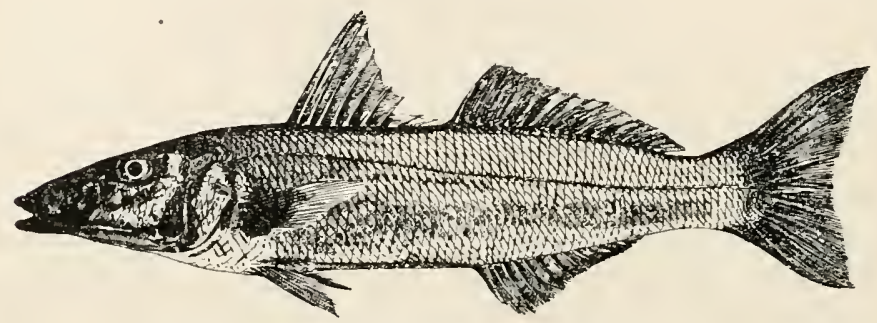

Fig. 40.-SANd Whiting (Sillagn cilitta).

The Sand Whiting is one of our sporting-fishes, and is captured in great numbers by hook-and-line; but the principal means by which the market supply is kept up, is by the use of the hauling-net. This fish has the habit of burrowing into the sand, and when a number of them are enclosed within a net-and more especially when it is nearing the shore-there is always a large percentage of them, that quickly burrow, so as to escape. If the fishermen dil not know of this habit, of course a large number of the Whitings would be lost, but they are well acquainted with the fishes' wiles: so they walk about in the sand in the water and when they feel a wriggle, put the hand down quickly and bring forth a struggling beauty. In other cases, the fishermen are able to locate their quarries as they are disappearing. The young also have this same habit of hiding themselves when danger is near.

The Sand Whiting is of a yellowish-brown, sand colour along the back, and silvery-white below. All over the sides and back are the most lovely purple, green and gold reflections and altogether it is a truly handsome fish. In addition to this, young examples up to about 4 to 5 inches. 
in length, possess a number of dark blotches along the upper half, somewhat similar to those in the next species to be mentioned-the Trumpeter IVhiting: but at no time are these blotches so pronounced, or so extensive, as in the lastmentioned Whiting. This is not generally known and is important to note, as many people are inclined offhand to regard these baby Sand-Whitings as Trumpeter Whitings.

This species attains a weight of about $2 \frac{1}{2}$ pounds, specimens of $\mathrm{I}$ pound to $\mathrm{I} / 2$ pound being not at all uncommon.

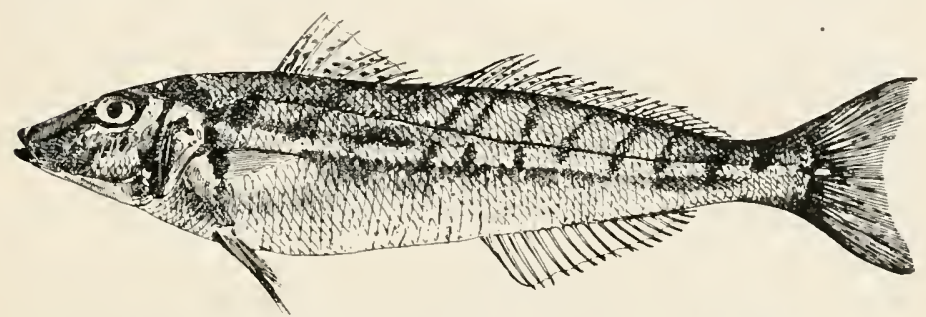

Wig. 41.-Trumpetek WhitiNa (sillago maculata).

The Trumpeter Whiting is principally an inhabitant of the waters of New South Wales and Queensland. There is one record of its occurrence in Western Australia. In its habits, this fish is still more of an estuarine or harbour fish than the preceding, living in moderately-deep water and preferring "muddy-sandy" bottons. It is not by any means what might be termed an "outside" fish; though no doubt occasional specimens might be obtained, particularly in localities like the offing at Broken Bay, where a great amount of silt is deposited from the Hawkesbury River.

In passing, here, I must state that the Whiting obtained by means of the trawl-net from the "Thetis" in I 898 and which was identified at the time as "Trumpeter Whiting," was not this species at all but another and a totally different species-Sillago bassensis. This is the Whiting which occurs commonly in Tasmanian waters. It is exceedingly abundant on the coast of New South Wales, in water ranging from a few fathoms, down to the great. depth of nearly 90 fathoms (540 feet). In Port Jackson, at the mouth of which this species is usually abundant in. the summer months, it is known as School Whiting. 
From the other Whitings this kind may be at once separated by its "clean," semi-transparent appearance, the prominent silver band running (longitudinally) along each side, and by the possession of a series of rusty-red diagonal blotches along the upper half of each side.

This species is the smallest of our known Whitings, growing usually to a length of 9 or ro inches. It is a delicious little fish for the table.]

Like the Sand Whiting, the 'Trumpeter Whiting is greatly valued for its excellence as a food-fish; but, not attaining to such dimensions nor being obtained in suci profusion, it is not nearly so important. The usual weight of those marketed, ranges from 4 to 5 ounces and it attains rarely to a weight of Io or II ounces.

In addition to being found on this coast, this fish occurs in India and the Malay Archipelago.

The Trumpeter Whiting is not so often captured by hook and line as is the preceding species, but is obtained with a hauling net of small mesh.

In colour this species is generally darker than the Sand Whiting, but at the same time is rather more transparent looking when fresh. There is a prominent, broad silvery stripe down each side of the fish, this being comparatively indistinct in the latter. The scales too in this kind are nore deciduons and the body is always characterised by the presence on the upper parts of a number of very dark, blackish, irregular blotches; these being, as before pointed out, quite absent in the adult Sand Whiting.

The Spotted Whiting occurs chiefly along the coasts of Victoria and Tasmania, though it is found also over about half the extent of the New South Wales coastline, becoming more common towards the southern boundary. It may be at once distinguished from either of the preceding by the more elongate body, the greatly increased number (and consequently decreased size) of the body scales and the presence of pretty Trout-like spots all over the upper half of the body.

It grows to a length of about 20 inches. 


\section{THE JEWFISG FAMILY}

(Family : Scionida.)

THRLE important species of Australian food-fishes are included in this family. they being the Jewfish (Scicenu antarctica), the Teraglin (Cynoscion atclodus), and the Salmon (Arripis trutta). About 150 species of the family: are found in various parts of the world, and they are mostly marine. Nearly all are of economic value, some beiner highly valuable. They are usually found on sandy shores in fairly shallow water. None of the species occur in very deep water. Many of them reach a very large size. They all, including the Australian species, subsist on animal food. Most of the Scicnida make peculiar noises, variously termed croaking, grunting, drumming. or snoring. Our own Jewfish is kilown to make a grunting sound. From this habit the whole family in America are known as "Grunters." The sound is supposed to be produced by the forced passage of air from one portion of the air- or swim-biadder to another. In these fishes the air-bladder is usually large and complicated, and provided with more or less numerous appendages. This air-bladder in the larger species-like our Jewfish-is greatly used for the manufactire of isinglass. One of the American species is responsible for making such a loud noise that it has earned the popular name of "Drun." The males drum the loudest, while the females' "voices" are softer. The drumming is particularly noticeable in the breeding season.

The Jewish is a voracious and powerful fish, attaining commonly a weight of from 60 pounds to 70 pounds, with a length of about 5 feet, though the weight of those principally brought to market runs from about 20 pounds to 30 pounds. It is common at all times along most of the eastern, and a portion of the southern, coastline of Australia, being particularly abundant on the New South Wales coast. It is also known from Western Australia. It inhabits the estuaries and harbours, and also the coastal beaches-particularly in the vicinity of lake-entrances. In some cases it ascends some of our coastal rivers right up into the fresh water. At certain times large 
shoals of them move about together, and prey on the shoals of Salmon and some other fishes. On the New South Wales coast one of the principal foods of this species (when it is in its favourite haunts) is Sand Whiting, but nothing of an animal nature comes amiss to this hungry fellow, and I have taken quite a number of other species of fishes from Jewfish stomachs as well as Crustaceans-Prawns and Mantis-Shrimps (Squilla). At times numbers of Jewfishes may be observed lying basking in the sunlight on the sands underneath the railway bridge at Como, George's River. N.S.W.; this forming a most interesting sight. In addition to being found on our eastern coast, this fish also occurs on the coasts of South and Western Australia. In regard to its relative abundance in Western Australia, nothing very much is known, but it is quite common in the mouth of the River Murray, in South Australia, where it is captured partly by means of floating meshing or gill-nets (chiefly at nighttime). The variety of common names under which this species is known in the various States forms a great objectlesson of the necessity for using the technical names in any written account of our fishes and their habits, otherivise they can only be misleading, and full of confusion; as what applies in the case of the Jewfish is found to apply with equal force to many of our other fishes. Some species are even known under different common names in localities not more than 20 or 30 miles apart, while different species are often only recognised under the one common title. The Jewfish is often known in Queensland as "Dewfish"; in Victoria it is known as the "Kingfish," while at the mouth of the Murray the fishermen call it "Mulloway," or "Butterfish." In Western Australia, again, it is called by the Victorian name of Kingfish. Wherever caught, and under whatever name, this handsome species is rightly regarded as a most valuable food-fish, and certainly it is a very profitable one, being what is termed "so meaty." In the principal cities of the Commonwealth it is one of the greatest resources of the restaurant-keepers, as it is excellent either served up as "Silver Jew," or perhaps what is more common as "Snapper." I am afraid the Jewfish has had to pay for a great deal of the Snapper's reputation in this direction. The term "Silver Jew" is properly restricted to young examples of 
about 2 feet in length, and less, and these are much more prized as a table accessory. As the Jewfish may be caught in immensely greater numbers than at present obtains, it is destined in the future to play a very important part in the fisheries of New South Wales at least, and to a somewhat lesser extent in the other States. The by-products from it -which are at present disregarded-will also be found of great value. Here I refer principally to the "sounds" or air-bladders which in this species are very large indeed, and are commercially of considerable value. At present thousands of these are thrown away every year with the offal, and as they require very little primary treatment beyoncl Arying, this is greatly to be regretted.

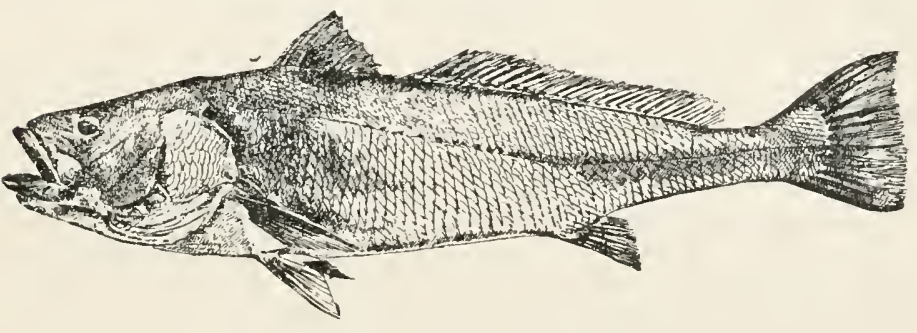

Fig. t2.-Jewrish (Sciena antaretica).

When freshly caught, the Jewfish is a most handsome object. The upper surface is dark-blue or brownish, this gradually changing into the light colour of the lower portions. All over the sides and upper portions the scales are flecked with silver and golden reflections, while over all there is a general iridescent appearance.

The Jewfish is sometimes known as "Jewel-fish," because of the so-called "pearls" which are obtained from the hearl. These "pearls" are the otolitls or "earstones," which, while occurring in the heads of other teleostean fishes, are particularly large in the species of the Scirnida. These earstones are closely connected with the sense of hearing. hence their name.

'The Tewfish, if not specifically identical, is very closely allied to an important food-fish of Europe known as the Maigre or Meagre (Sciana aquila).

The Teraglin is very like its cousin, the Jewfish; but does not attain to the large size of that species. It com- 
monly reaches a length of 2 feet or a little over. It may be at once distinguished from its congener by the relatively much smaller scales, there being, for example, about 75 scales on the lateral line of the Teraglin, while there are only about 52 on that of the Jewfish. The Teraglin also possesses a more silvery appearance than the Jewfish. So far the Teraglin has only been obtained along the New South Wales coast, where at times it appears in very large numbers. It is a rapacious fish, like the Jewfish. As a table fish it is considered of some value; and, consequently, it always commands a fair price in the fish-markets of New South Wales.

The Salmon occurs in abundance along the whole of the New Sonth Wales coastline. It is also found all along the southern coast of Australia, parts of Western Australia. and is quite common in Tasmania and New Zealand. In the last-mentioned place it is often known under the Maori designation of "Kahawai," and occasionally as "Sydney" Salmon." It must be at once pointed out that this fish is not a true Salmon, and is, indeed, very far removed from that fish in its structure; but when it is living it possesses beautiful Salmon-like markings, and these, coupled with its salmonoid form and its habit of travelling in immense shoals, have given rise to the present common name. The young or half-grown forms of this species have the Salmon or Trout-like markings still more pronounced, and they are consequently termed Salmon-Trout, being also often known to fishermen by the name of "Newfish."

Though at the outset I included the Salmon with the Jewfish and Teraglin as an important species, it does not possess anything like the food value of either of those fishes. Particularly is this so in the case of the adult, the young or "Salmon-Trout" form being far more palatable, and more eagerly sought after. Still, the vast and almost incredible size of the shoals of this fish, which appear along the coast in the warmer months bring it irresistibly under our notice, and enable it to be plainly seen that the Salmon is destined some day to play a very important part in our fisheries; as. even if it were not thought of sufficient use to turn into food. it might be quite profitably turned to account in the manufacture of fertilizer and various fish-products. This is done in various parts of the world at present-notably in America 
-in the case of a number of fishes which are not ustually considered as edible. However, there does not appear to be any reason to think that the Salmon will have to go begging as a fertilizer when fishing operations and fish-preserving are carried on together on a large scale in our waters.

The Salmon may be said to be one of our "game" fishes. It readily takes a moving spoon or spinning-bait, and affords some sport to anglers, particularly those of a more adventurous nature. It commonly reaches a length of 2 to $2 \frac{T}{2}$ feet, with a weight of 8 or 9 pounds.

Though the Salmon has been here included in this iamily of the Scicrnice it should be mentioned that the proper systematic position of the genus Arripis has been for long a matter of some difference of opinion on the part of naturalists, as the species of this genus show pronounced affinities with families of fishes which are widely separated. This makes it somewhat of a paradox. It is sometimes placed with the Serranida.

Another species of Arripis that is found on the southeastern and a portion of the southern coastline of Australia is the fish known in South Australia and Victoria as "Roughy" (Arripis georgianus). This has no affinity with the fish mentioned under the name of "Roughy" on page 89.

\section{THE SILVERBEILIES.}

(Family: Gerrida.)

A NUMBER of species of the Silverbelly family are found in Australian waters and they are chiefly of small size. The principal one is the pretty little common Silverbelly (Xystama ovatum). This fish is known from the coasts of New South Wales and Queensland, there being, also, one record of its occurrence on the shores of Western Australia. It attains to a length of about Io inches; though the average length of adult examples is from 7 to 8 inches. It is of a most beautiful silvery colour; the back being tinged with 
green or greenish-brown. The scales are lighly deciduous. Une of the most striking characteristics to the casual observer will be the extraordinary telescopic mouth of this little food-fish. The Silverbelly is a harbour or estuary fish and it finds its food-which is of an animal nature-in the vicinity of weedy and muddy flats. Other names by which it is sometimes known are: "Silver Bream" and "SilverBiddy." In America the fishes of this family are known under the general name of "Mojarras."

When freshly cooked the flesh of the Silverbelly is highly delicious.

\title{
THE TRUMPETERS.
}

\author{
(Family: Latridider.)
}

To this family belongs that important and valuable foodfish known as the Tasmanian Trumpeter (Latris hecateia). This fish grows to a large size, and is greatly esteemed as a table-fish on account of its delicacy of flavour. Examples of the weight of 60 pounds are sometimes caught. It has only been taken so far on the coasts of Tasmania. Victoria and South Australia. It is said to occur sparingl! on the coast of New South Wales, but there is no authentic record of such. An allied species, the Bastard Trumpeter (Latris ciliaris) is fairly common on the southern portion of the seaboard of New Sonth Wales and off Victoria and Tasmania, being also fonnd in New Zealancl. It does not. attain to anything like the size of its handsome and valuable congener just mentioned. Another food-fish of some value -thougl considerably less important than either of those spoken of above-is the Kelpfish or Marbled Morwong (Chironemus marmoratus). It is a widely-distributed species, having been taken from localities so far apart from one another as North-Western Australia, Lord Howe Island, Tasmania and the coast of Victoria and New South Wales. It is essentially a rock-fish and is carnivorous. It is common along portions of the New South Wales coast- 


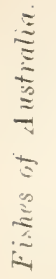

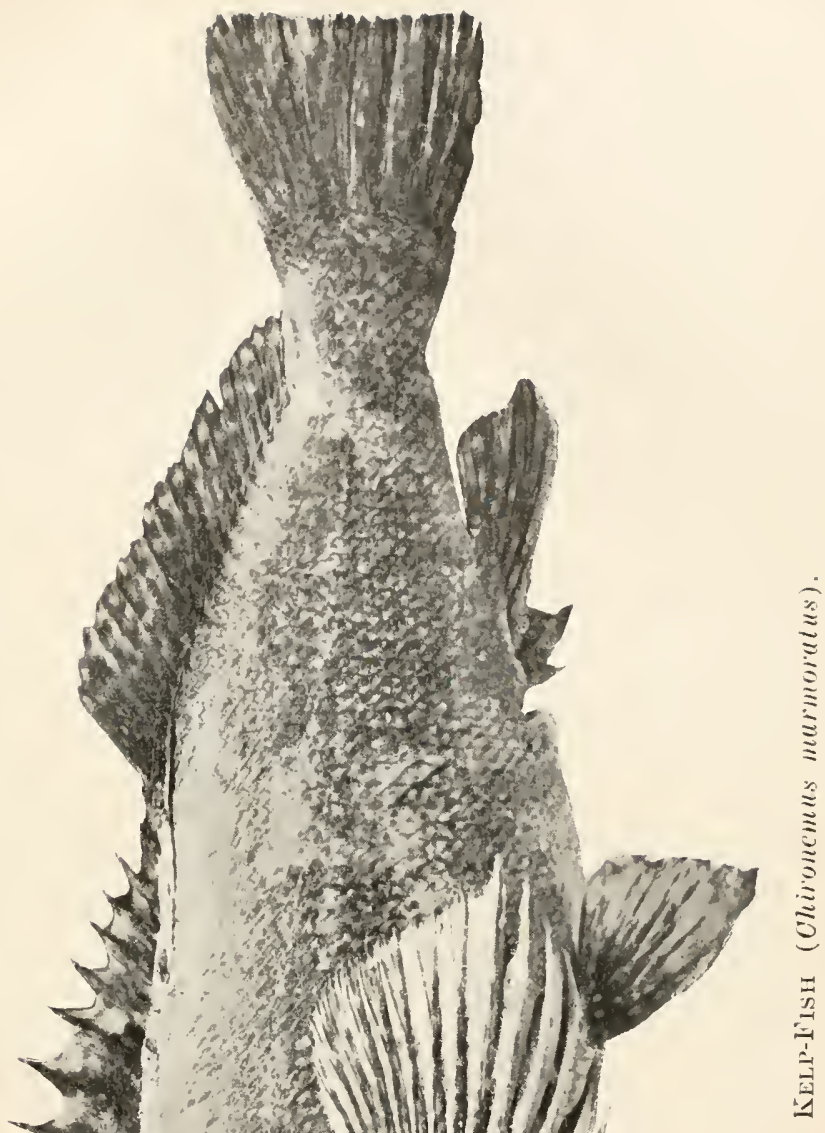

$\Xi$ 

line in localities where weed-covered rocks abound and there it may be taken by hook-and-line or by means of the trammel- or meshing-net set close in against the rocks. This fish is not uncommon in, and at the entrance to, Port Jackson. In the harbour itself, it is to be found in such localities as George's Head and Bradley's Head and also around Clark Island and Shark Island.

The Kelpfish is a very pretty little species; being of an olive-green or light-brown, marbled over with rich dark reddish-brown; the whole being evenly speckled over with sma!l, bright, yellowish-red or golden spots. It commonly attains a length of Io to 12 inches.

\section{THE MORWONG FAMILY.}

\section{(Family: Aplodactylida.)}

This is quite an important family, as it embraces, in addition to several others, such well-known and valuable forms as the Morwong (Dactylosparus carponemus), the Jackass-Fish (Dactylosparus macropterus), the Sea-Carp or Red Morwong (Chcilodactylus fuscus), and the so-callerl Cockatoo-Fish (Aplodactylus lophodon). The first of these is a fine fish, of good edible qualities. It has a fairly wide distribution, being known to occur along the greater part of the New South Wales coast, as well as those of Victoria, Tasmania, and New Zealand. It is never taken in very great abundance in any fortion of its habitat. Probably this is the fault of the appliances, and not through any scarcity of the Morwong itself. It may be taken by either hook-and-line, or with the aid of the trammel-net on rocky and sandy ground, and in the vicinity of "bomboras." Two fine, coloured illustrations of this species are given on plates I73 and I74 of MicCoy's "Prodromus of the Zoology of Victoria."

The Jackass-Fish is generally confounded by amateur fishermen, and many others, with the Morwong; and, as it 
is a common fish, and more easily taken than the latter, I have found that the greater number of so-called Morwongs brought in to market are really the species that we are now (jealing with. In this species, the head has a more draw1cut appearance than in the Morwong, and there is a wide, addle-like, purple band over the shoulders. It is this character that has earned for the fish its common, name. I,ike the Morwong, this fish has an extended range, and it is found in very similar localities. In Tasmania it is fairly common, and is known both as "Perch" and "Silver Perch." In New Zealancl, where it is more commonly obtained than in any other portion of its habitat, it is known nunder the Maori name of "Tarakihi." It attains a length of from 18 inches to 2 feet.

Both the Morwong and the Jackass-Fish are considered to he first-class fishes for table nse.

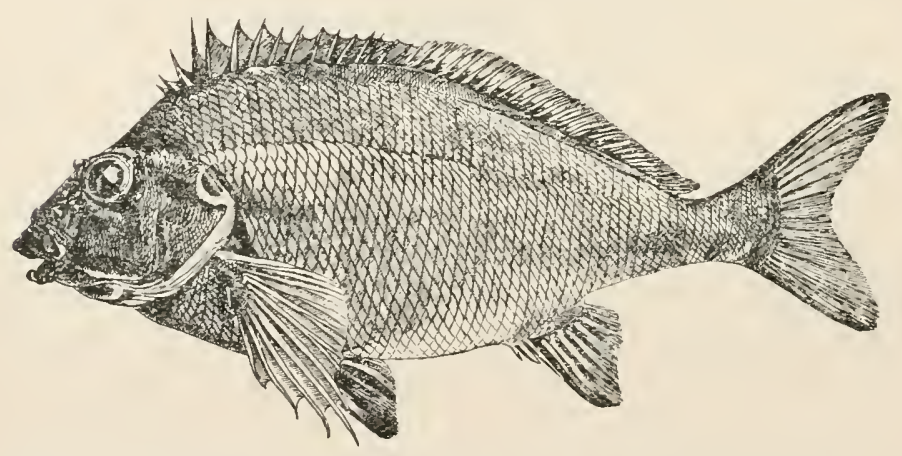

Hig. 4\%.-Sea Carp, on Red Murwunti (cheiloductylus fuscius).

The next one of this family to be considered is the SeaCarp. This well-known fish is restricted to the waters of New South Wales-so far as is at present known-and is one of the State's finest food-fishes. It is an exceedingly handsome species at all times, although there is a considerable amount of variation in colour. The general colour of the body varies from a bluish-silvery to a light reddishbrown, each scale having a reddish-brown margin. There are usually a number of vertical bars interspersed at regular intervals along the body in the adult, and always in the young. The young, it may be acled, are uniformly lighter 
in colour than the adults. There is a beautiful orangecoloured band round each eyc, and an orange patch at the edge of the operculum on the body. Both the dorsal and catndal fins are edged with orange.

An interesting point in the structure of the three species of this fanily which we have so far discussed, and which the ordinary observer will not be likely to miss, is the remarkable slape of the pectora! fin. In this, one of the lower rays is great!y elongated, and possesses a peculiar finger-like appearance. This feature is particularly striking in the Morwong and Jackass-Fish. Other features of interest are the thick, fleshy lips and the prominent, knobby protuberances over the eyes.

Young Carp from about 8 inches in length downward are very often taken, when a net is hanled to land over a "grassy" flat in the lower waters of Port Jackson; particularly if the flat is in the neighbourhood of rocky ground. The adult is almost solely an "outside" fish, being quite common around sunken reefs, bomboras, and rocky shores, where it obtains for its sustenance small Crustaceans, Worms, Shells, \&c. In the harbour of Port Jackson itself, examples are occasionally taken about Clark Island, Shark Island, George's Head, Bradley's Head, and a few other somewhat similar localitics.

The ordinary means of capture employed for the Carp are either hook-and-line or the trammel-net.

Another fish of this family that is very common, but, at the same time, is not often seen by the average person, is the Cockatoo-Fish. This is a vegetable-feeding, "outside" rock-fish, which subsists principally upon gelatinous seaweeds. It is a very dark-coloured fish, with somewhat lighter mottlings. The skin and scales have a leathery feeling. It has a most peculiar-looking head; very suggestive of that of a cockatoo-hence its common name. From the occipital portion of the head, the back suddenly rises to the dorsal fin, and this heightens the generally peculiar appearance of the fish. It commonly attains a lengti of 18 inches or more.

The Cockatoo-Fish is not usually caught by hook-andline, though occasional specimens have been captured in that way. The only proper and really effective manner is by 
means of the trammel-net. 'Though, as I mentioned, this is an outside fish, still it is not uncommon about the rocky portions of the lower waters of our harbonrs.

\section{GRUNTERS AND BOAR-FISHES.}

(Family: Pristipomatid ${ }^{\text {.) }}$

'THIs family is very well represented in Australian waters, amongst the number being several food-fishes. Of the "Grunters" I might mention; the little Trumpeter Perch (Tcrupon quadrilincatus), the Silver Perch (Terapon ellipticus), and the Queensland Trumpeter (Pomadasi.; hasta); while of the four species of Boar-Fish the most important are Richardson's Boar-Fish (Histiopterus recurvirostris) and the Giant Boar-Fish (Histiopterus labiosus).

The Trumpeter Perch is a very widely distributed fish. In addition to being found over the greater portion of the New South Wales coastline, and probably the whole of that of Queensland, it occurs in the waters of New Guinea, th seas of India, the Malay Archipelago and China. Though it is quite a small species, usually attaining a length of about 8 inches, it may be quite properly classed as one of our edible fishes, as it is excellent for table purposes. This has been recognised more of late years, consequently more of them are consumed.

The Trumpeter Perch is quite common in many parts of Port Jackson, particularly on shallow, sandy bottoms covered with sea-grass, against gently-sloping beaches.

In common with the real fish of that name, this little species is often called "Mado," principally by juvenile anglers; but the fishermen usually recognise the difference between these two, and apply to the Trumpeter Perch the name of "Trumpeter." This is, however, misleading; as it has 110 close affinity with the Trumpeters properly so-called. 'The term is given to it because of its habit of making a half-grunting half-buzzing sound after capture. 


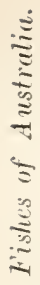

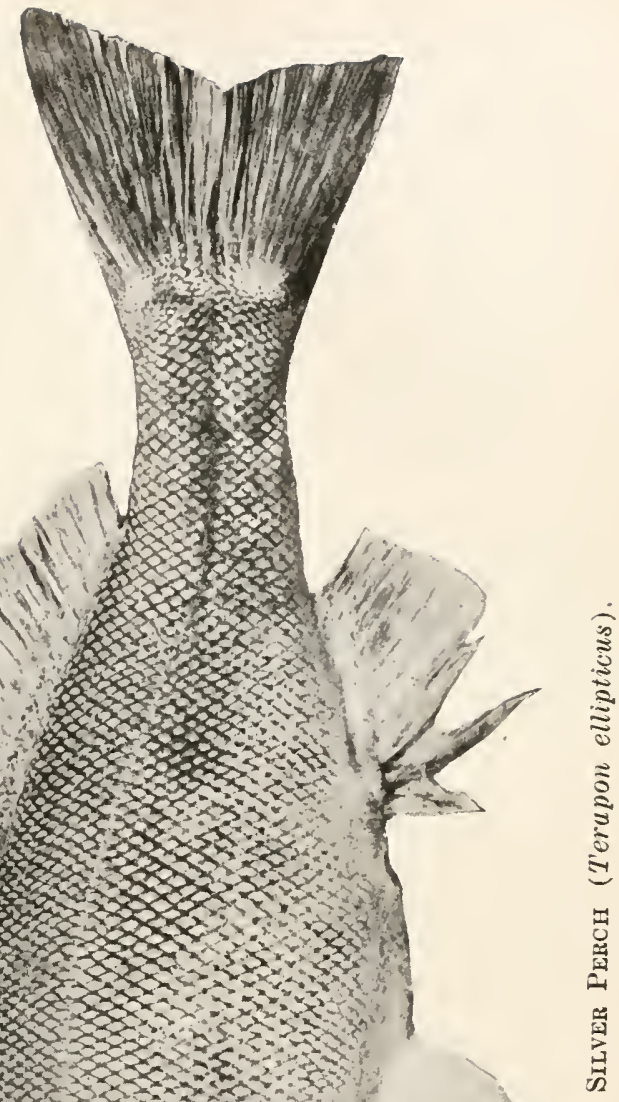

$=$ 

This fish has a very pretty appearance; the body being of a greyish-green tint and having a number of longitudinal bands of, ustially, a brownish tint, running along it.

The Silver Perch is one of the best known amongst our fluviatile food-fishes. It occurs in the whole of the waters of the Murray River system, even $11 \mathrm{p}$ into parts of Queensland, and down to the limits of salt-water in South Australia. It attains a weight of about 5 pounds, and is highly prized wherever it is known, on account of its edible value. Though occasionally obtained by means of hook and line the usual way of capturing it is with the gill-net-as in the case of the "Golden Perch."

The Silver Perch is really a most beantiful looking fish both as regards colour and shape. It has a uniformlysilvery appearance; the body, particularly the back, being finely dotted over with a darker colour and each body-scale having a very pretty dark outline. In many parts of western New South Wales, this fish is familiarly-known as "Grunter" ; because of the grunting or snorting sound made by it when captured. It is also known as "Black Bream" in some parts and in others "Silver Bream." The native. Murrumbidgee name for it is said to be "Kooberry." On the lower reaches of the Murray River in South Australia, the aboriginal name of "Tcheri" or "Cheerey" is used.

The Queensland I'rumpeter: The Australian home of this magnificent food-fish is principally along the coast of Queensland, where it is well and favourably known. It also abounds to some extent on the northern portions of the New South Wales coast. and is found in Western Australia. In addition to its Australian habitat, it is known from the Red Sea, the east coast of Africa and the Malay Archipelago.

In addition to the name given above, it is also known in Queensland as the "Javelin Fish."

The casual observer would pass this fish as "a kind of Bream"; and certainly it is rather Bream-like in shape.

The colours vary with age, but the body is usually prettily ornamented along the upper parts with prominent irregular dark spots.

In our waters this species grows to a length of at least 
$21 \mathrm{I} / 2$ inches; that being the size of the largest example handled by me; the specimen being from the Macleay River, N.S.W.

Richardson's Boar-Fish: This remarkable looking fish has achieved fame because of its peculiar appearance, ratiher than through its importance as an edible fish. Still, in the latter respect, it has already gained some renown, as it attains a length of nearly 2 feet, and the flesh is much esteemed as food. It is found chiefly upon the coasts of Victoria and Tasmania, also being, occasionally obtained

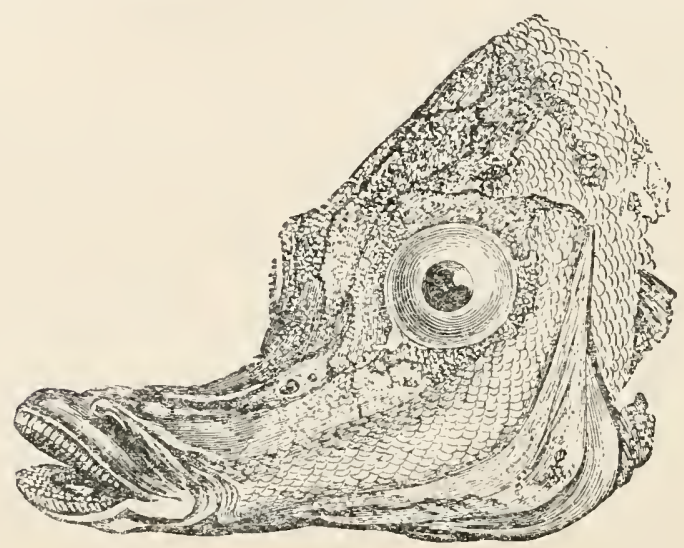

Fig. 44.-Head of Richardson's Boar-Fish (Histiopterus recurvirostris).

upon the southern seaboard of New South Wales and Western Australia. The most remarkable portion of this fish is the head, in which the snout is greatly produced, the small mouth being situated at the extremity of the snout. Taking the front part of the head alone there is a quaint, far-away suggestion of the head of a gigantic sea-horsewithout any of a sea-horse's trimmings.

The Giant Boar-Fish: If one is to go by actual appearances, this fish is more deserving of the name of "Boar" than any of the others, there being an undoubted suggestion of a "Tamworth" Pig. It is distributed over the greater portion of the coastline of New South Wales, Victoria, South Australia and probably Tasmania. It is a fine fish, growing to a large size (specimens of over 2 feet in 
length being not uncommon). Though there is really no reason to think that this fish is uncommon, it is not brought to market very often. The reason for this is not very far to seek as the Giant Boar-fish dwells and obtains its food upon sandy ground in deep water; the same kind of grouncl as that upon which the "Old-Man" Snapper is found. Here it lives wholly upon marine organisms which live in the sand. Very few people fish in these localities, except those who fish for "outside" Flathead; in which case the bait used would be too large for the comparatively small mouth of the Giant Boar-Fish.

It will be observed that the snout in this fish, is admirably adapted for "grubbing" in the sand for food; just as in the previously-mentioned species, the long-drawn-out snout is so wonderfully suited for poking about amongst crevices and crannies in rocks, enabling the fish to pull small marine animals out of places which it could never reach, if it had a blunt muzzle.

The Giant Boar-Fish is of a greyish-colour; lighter below; with wide, dark, brownish, longitudinal bands on the npper part.

\section{THE BREAM FAMILY.}

(Family: Sparide.)

HERE we come to another and still more important family of Australian fishes which includes two, at least, of our most important food-fishes-the Snapper* (Pagrosomus auratus) and the Black Bream (Chrysophrys australis).

Amongst the other members of this family might be mentioned the Tarwhine (Chrysophry's sarba) and the Yellow-mouthed Perch (Lethrinus chrysostomus).

The Snapper: What the Murray Cod is amongst

* There appears to me to be no sound etymological reason why the name of this species should be spelled "Schnapper." The mere fact of its having been spelled in that way by so many is not a sufficient justificatinn. 
our fresh-water fishes, the Snapper is, in the fishes of the sea; and it is generally looked upon as the principal fish, both for sporting and food purposes, to be obtained in our waters. The latter part of this statement of course does not refer to comparative quantities obtained; for, undoubtedly the Mullets hold their own in that respect.

The Snapper is found on the coast of every State in the Commonwealth (as well as New Zealand), but as far as we know is most abundant in New South Wales.

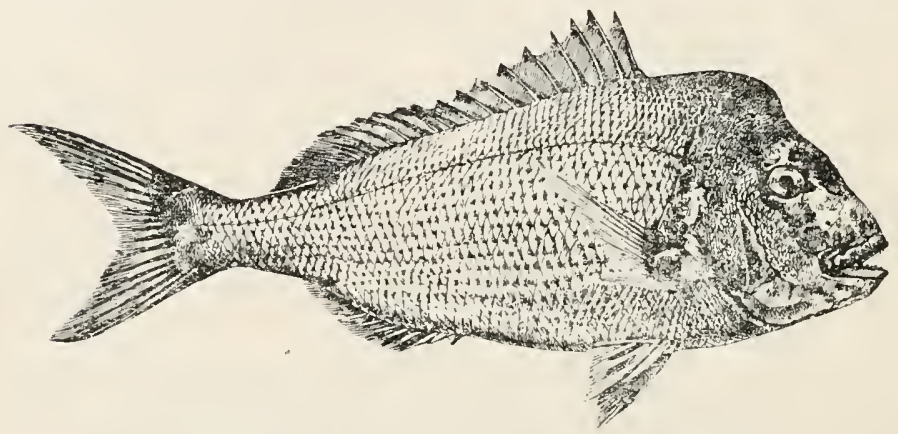

Fig. 45.-SNAPrER (Pagrosomus allutus).

At one stage or other of its growth, it must be a familiar object to most of my readers; or at the very least those who resirle in coastal districts.

'Though the adults frequent principally the "outside" grounds in the vicinity of sunken reefs and bomboras, the young-familiarly known as Red Bream-are quite common in the lower waters of our harbours, where they are eagerly songht after by many an angler, young and old.

Up to about 4 or 5 inches in length, the young fry of the Snapper, which are then characterised by the possession of dark vertical bars on the body, are very often known as "Cockneys." I should have mentioned that the prevailing colour of the Snapper throughout life is a most delicious pink; which becomes, usually, richer and a little deeper in tint with increased age.

Beyond the "Cockney" stage and 1ip to a weight of about a pound and a half, the Snapper is known as Red Pream, that is in the restricted sense of the term. At the beginning of this stage, the vertical bars gradually disap- 
pear and most beantiful pale-blue spots, which before were quite noticeable, now become very prominent; particularly on the upper surface of the body. Later on in life and up to a fairly-large size, this species is known to the fishermen first as "Squire" and then as "School Snapper"; while beyond this stage, we get what is known as the "Old-Man Snapper." At the last-mentioned stage, the fish is characterised by a tremendous, bony protuberance at the top of the head; and, at the same time, a flabby, fleshy nose, of almost human appearance is former. At this time, the likeness of the Old Man Snapper's countenance to a human face, is often most remarkable; particularly when-as is so often the case-the nose has the bloated appearance of an inebriate's. The Old Man Snapper is sometimes caught of a weight of over 30 pounds. It is found on sandy bottoms in fairly-deep water, where it stibsists chiefly upon starfishes, sand-rvorms, crustaceans, etc. One would think that the condition of the teeth at this stage might have something to do with this change of habitat, as they are then worn and often decayed.

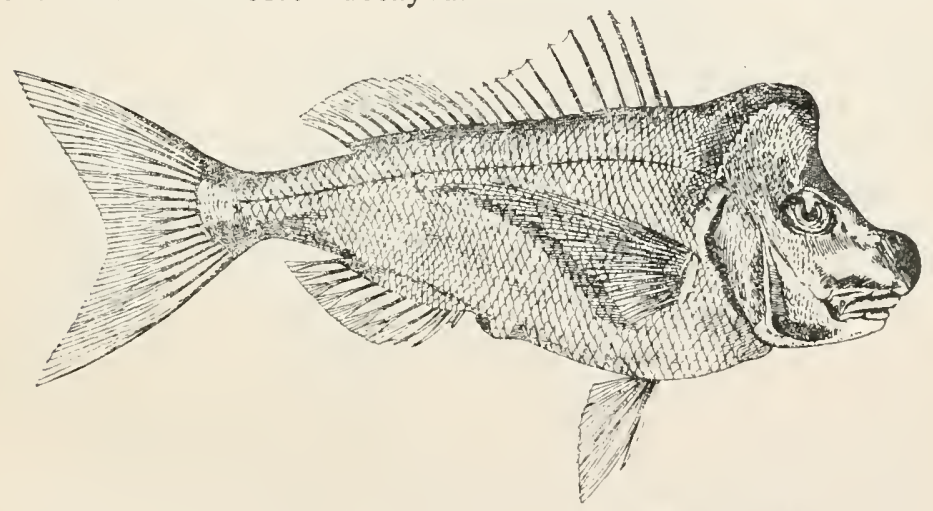

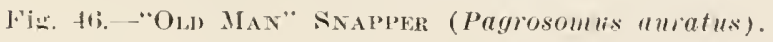

It is worth mentioning that all of the large "Old-Man" Snappers that I have examined have been females; therefore the tern "Old Man" appears rather out of place. The same thing applies equally, as far as my experience goes, in the Black Brean1, Blackfish and Mullet.

"Wollomai" is a name given by some New Soutli IV ales blacks to these old examples of the Snapper. 
Black Bream: This famous Australian fish, which is of such immense importance both as a food and a game fish. is found along the greater portion of the Australian coastline. On the coast of New South Wales, it is particularlyabundant, inhabiting all the coastal lakes and estuaries, where it frequents rocky and sandy bottoms, subsisting chiefly upon small crustaceans and mollusks. It is easilv able to reduce to fragments, even fairly stout shells, by means of the powerful molars on each side of the jaw. The Black Bream is seldom taken on the ontside gromnds.

This is so well-known as a sporting-fish, that there is no need for me to here enlarge upon its virtues in that respect; suffice it to say, that the angling for it, affords a pleasurable occupation to many thousands of our amateur fishermen. Often the most tempting of baits and the finest of lines have to be used, before this wily fellow can be hooked. And when he is hooked what a brave fight he makes!

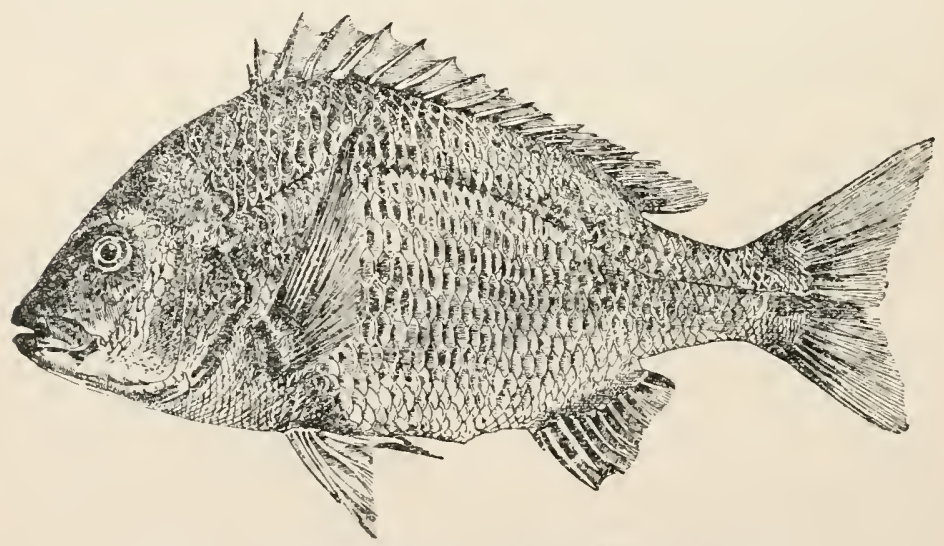

Fig. 47.-BIACK BREAM (Chrysophrys australis!.

As a food-fish, it is always sought after, finding a ready sale, both wholesale and retail. Some idea of its great importance, may be gathered when I state, that in the Fisi Markets of New South Wales alone, about 18,000 baskets (of about 75 pounds weight each) are sold annually.

The Black Bream attains a weight of about 6 pounds. One in the collection of the N.S.W. Department of Fisheries 
weighed while fresh, $53 / 4$ pounds, and measured 20 inches, while another of about the same length, weighed $47 / 8$ pounds. Both of these were from Lake Macquarie, New South Wales; which may be said to be the richest Black Breanı water on this coast.

The Tarwhine: This fish is more of a tropical species, than the preceding: consequently it becomes more common on our coast as we proceed in a northerly direction. It occurs on at least two-thirds of the New South Wales coast, and along the whole of the eastern coast of Queensland. In addition to this, it has been recorded from IVestern Australia and a portion of North Australia, and inluabits the waters of New Guinea, the Malay Archipelago, the Seas of India and the Red Sea. In appearance, it is somewhat similar to the Black Bream; and, by many people, is often confused with that fish; but a very cursory examination by even the most casual observer, will be found quite sufficient to bring out most striking points of difference between the two. Many of these differences might be enlarged upon, but it will be sufficient to mention here that the Tarwhine has what is termed "a more bull-nosed appearance" in the head than the Bream, that it has a number of somewhat broad, yellowish-golden longitudinal stripes along the body (particularly on the upper portion), and that it has II softrays in the anal fin as against 8 in the Bream. Also, the spinous rays of the anal fin are very weak when compared with those of the latter.

Though the Tarwline is of considerable commerciai value, it is not to be compared to the Black Bream.

It attains a weight of several pounds.

Yellow-mouthed Perch: This handsome fish is, like the preceding, a tropical species; and consequently, is only. obtained occasionally on the New South Wales coast; its home as far as Australia is concerned, being in Queensland; where it is also known as "Yellow-mouthed Snapper."

This is an exceedingly-handsome species when alive, retaining a great deal of its beauty for a considerable time after capture. Each scale of the upper half of the body, has an irregular, opalescent, central blotch, with a brownish spot at the base. Inside the month and immediately around 
the lips is of a rich orange-red. On each side of the head, there are several bluish streaks, while at the summit there is an irregular line of bluish blotches. The face and the opercle are golden-yellow; and the iris is of a golden-red. The fins are beantifully ornamented with red, blue an' 1 yellow, and altogether the fish has such a beautiful appearance, that, once seen, it is not readily forgotten.

It attains a length of about 3 feet.

A closely-allied species is known in Queensland as "Emperor," on account of its glorious colouration.

\section{RED-MULLETS OR GOATFISHES.}

(Family: Mullider.)

I's should be at once understood by the reader, that "RedMullets" are not really Mullets; that is to say, they are not at all closely related to that family which contains all of our so-called "Grey-Mullets" (Sea Mullet, Flat-tail Mullet, etc.), previously referred to on page 73. Probably if we were to go back to the origin of the name, it would be found that these fishes really had a prior right to it; but as the very large family of the "Grey-Mullets" is universally" recognised by that name, in the whole English-speaking world; at the same time, containing as it does, so many important edible species, it is more expedient to retain the title for them. In America, the Red-Mullets are recognised under the name of "Goatfishes" and this appears to me $d$ rather appropriate and useful title; I will therefore use it as a terminal in the common names of our own fishes of this family. This will be generally recognised as the better thing to do, rather than to perpetuate a confusing and misleading title.

Though a number of species of the Goatfishes are found in Australian waters, little is known regarding their habits or even their distribution. I will therefore only speak of three kinds which are known to occur on the coast of 
New South Wales. These are: the Blue-striped Goatfish (Upeneus porosus), the Spotted Goatfish (Upeneus signatus) and the Bar-tailed Goatfish (Upeneus tragula). Of these the principal one is the Blue-striped Goatfish. This attains to a larger size than any of the others, and is at the same time the most common. Generally speaking the Goatfishes are small species; but ordinarily-large examples of the kind under discussion are about ro inches in length.

The Blue-striped Goatfish is distributed over the whole of the coast of New South Wales and is also known from Victoria, Queensland, South Australia, WVestern Australia and New Zealand. In the last-mentioned place, it is sometimes known under the Maori name of "Pakurakura."

The largest specimens brought into the Sydney Fish Markets, are usually obtained in Port Jackson, by means of either trammel-nets set around the rocks, or by sunken prawn-nets hauled in fairly-deep water. Small specimens may be obtained in large numbers in Port Jackson, by means of hauling-nets, drawn over sandy-"grassy"-flats, in such localities as Grotto Beach-at the entrance to Middle Harbour-and, also, the beach near the head of North Harbour.

The observer will notice the barbels which hang from the chin in this fish. These are typical of all the Goatfishes and are tactile organs, assisting the fishes to locate their prey, which consists largely of small crustaceans, worms, etc.

Amongst these fishes we find displayed the very richest of colours; but the fishes have to be seen alive to be properly appreciated, as these colours disappear to a very large extent, immediately after death.

The Blue-striped Goatfish is so named because it possesses on each cheek, several narrow bands of a most beautiful light-blue. The body generally is of a rich carmine, with violet reflections above; the lower surface being silvery-white.

The Spotted Goatfish is found over a large part of the New South Wales coastline but has not so far been recorded from any of the other States. It is not so common as the preceding and does not usually attain to a larger size than ahout 8 inches. 
In colour this fish is a pretty red, the upper surface being of a deeper tint-almost brownish. A broad dark band runs along the body on each side, from the operculum, and on the back of the tail is a large blackish spot. From the last-mentioned character it lhas derived its nane of "Spotted" Goatîsh.

The Bar-tailed Goatîsh: Though this remarkably beautiful fish has until recently only been known in New South Wales from a very few specimens taken in Port Jackson, there is no reason to think that it is very rare. The localities that it appears to usually frequent are somewhat outside the scope of the fisherman's hauling-net, being on bottoms of a more-or-less rocky nature.

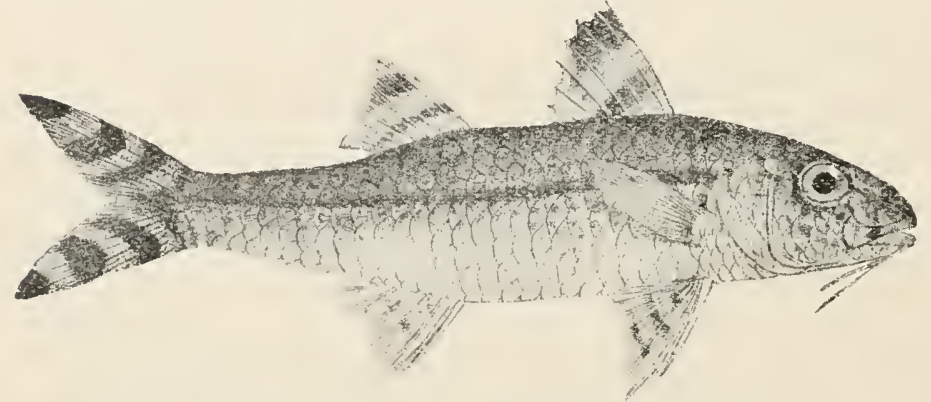

Fig. 48.-BaR-talled) (iontfish (Upeneus tragula).

In addition to its very different colouration, this species differs from both of the preceding, in the general shape of the body, which is lower and has a more rounded form.

In colour it is as follows: The sides are somewhat silvery, the upper parts are of a dusky-roseate tinge, spotted with brown, while below it is whitish or pinkish. A brown longitudinal band passes from the eye through the snout to the base of the caudal fin. The dorsal fins have dark bands. and each lobe of the caudal fin has five or six oblique brownish or blackish bars.

The Bar-tailed Goatfish is known to occur in the Seas of India and the Malay Archipelago, and it will probably be found to be fairly common in the waters of Queensland. 
The Sweep Family - The Coral-Fishes-The Surgeon-Fishes-The "Black Trevally" Family-The Pomacentrids-The Parrot-Fishes or Wrasses,

\section{THE SWEEP FAMILY.}

(Family: Scorpidida.)

THE Australian representatives of this family of fishes are not of much importance as food fishes, but amongst their number are several very interesting forms. I will here just hriefly speak of three species: the Sweep (Scorpis aquipimnis), the Mado (Atypichthys strigatus) and the Batfish (Monodactylus argenteus). The most important of these is the Sweep. This species is very abundant along the coast of New South Wales, and is a very familiar fish to most waterside folk. In localities like Port Jackson the young, up to about 6 inches in length, are exceedingly abundant around the rocky parts of the lower portions of the harbour, where they, in company with their relation, the Mado simply swarm. In his boyhood days, the writer has captured hundreds of both of these fishes in localities such as those mentioned. No special skill is required, as the little fishesboth species-are very ravenous after anything in the shape of animal food. The adults (of the Siveep) are usually found on the outside grounds; but are not very often taken, probably not because they are any less hungry than they were in the days of childhood, but because the baits and hooks used either for Snapper or Nannygai are usually too large for their comparatively small mouths.

The Sweep is fairly good for table purposes, and attains a length of 12 or 13 inches.

In colour, it is of a tuniform bluish tint on the sides, being a little darker above and a little lighter below.

In addition to its occurrence in New South Wales waters it will probably be found to be fairly abundant in Victoria. and it is known to occur in West Australia. 
The Mado is a smaller species than the preceding, though one would not think so were he to judge by the relative sizes of the specimens of each kind captured by line off the rocks in Port Jackson; but the mature Mado is caught under these circumstances, while the adult Sweep seldom is.

The Mado is a handsome little fish, having alternate brown and yellow longitudinal stripes along the body.

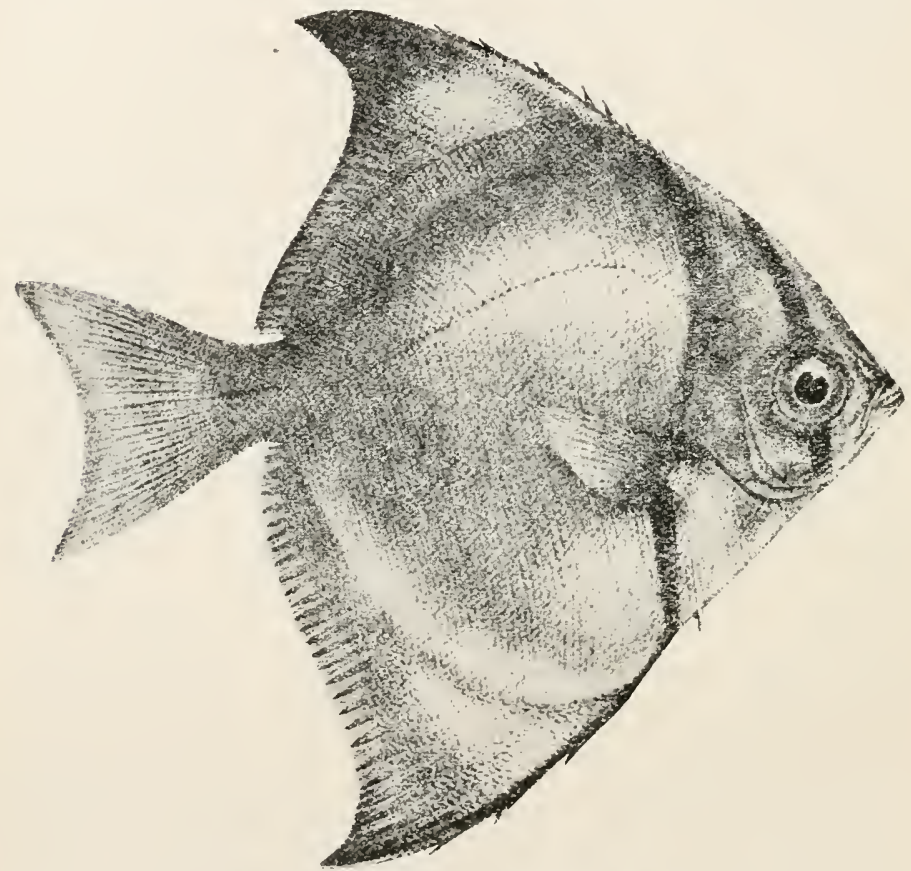

Fig. 49.-BatFish (Momolarlylus argenteus).

The Batfish is common from a little south of Port Jackson all along the coastline of New South Wales and Queensland; but, like many other fishes, is not often sean by the average person, and consequently is usually classified amongst our rarer forms. It is a very deep, short, and narrow-bodied fish; the scales are very smooth. When freshly taken it has a most brilliant, silvery appearance, with the exception of the head, which has two dark vertical bars upon each side. When the fish is "sailing" along in the water-as I have seen it,-these bars give it a very remarkable appearance. 
The largest example that I have seen measured about 8 inches.

The geographical range of this species is very extensive, as, in addition to its occurrence in Australia, it is known from the Red Sea, the East Coast of Africa, the seas of India, the Malay Archipelago, and other localities.

\section{THE CORAL-FISHES.}

\section{(Family: Chatodontida.)}

THE Coral-Fishes are closely allied to the preceding family. They are well represented in Australian waters, and include one or two food-fishes. The most interesting or noteworthy, are perhaps the Coral-Fish (Chelmonops truncatus), the Striped Chaetodon (Chatodon strigatus) and the Butter.Fish (Ephippus multifasciatus).

Nearly all the fishes of this family are noted for the remarkable-and often brilliant-colouration of their bodies: the colours generally being arranged in the form of bands or stripes. The fins are very scaly, the skin of the body. being continued for some distance up each side of the dorsal and anal fins. Any bands of colour which exist, are usually continued ont on to these fins, thus giving to these fishes quite a different appearance to other striped fishes possessing unsheathed fins.

I have mentioned the Coral-Fish because of its remarkable appearance. Very little is known of its habits. Its snout is long and drawir out into a kind of tube. The body is high and narrow, and the hinder margins of the dorsal and anal fins are vertical; the one being in line with the other. Along the fish, from the snout to the tail, are broad, zebra-like, vertical bars of-usually-brown and yellow.

The Coral Fish is occasionally captured in Port Jackson and on other parts of the New South Wales coast as well as in Western Australia. 
The Striped Chaetodon is something like the Mado in appearance, having black and yellow longitudinal bands along the body; but the body is much higher and the bands are arranged more obliquely, than in the Mado. Still, notwithstanding these and other points of difference, the one is often mistaken for the other.

This species is not uncommon on the coast of $\mathrm{New}$ South Wales. It is also said to occur in the waters of Western Australia and is known from the Seas of China and Japan.

It attains to a length of about 6 inches.

The Butter-Fish is an inhabitant of the shores of tropical and semi-tropical Australia ; being very abundant in parts. It has been recorded from New South Wales, Queensland, North and Western Australia. On the New South Wales

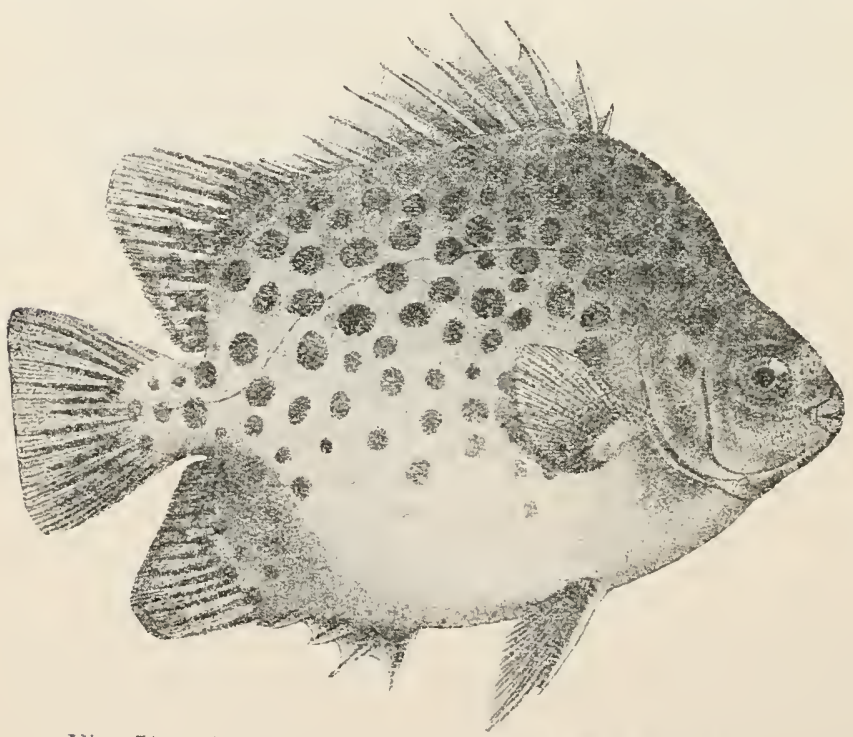

Fig. 50.-NơtTEU IOUTTER-Fisn (Ephippus argus).

coast, it is found about as far south as Port Jackson, and from there becomes more common as we proceed north. In the estuaries of the great northern rivers-the Clarence and the Richmond-it is quite common. This fish also abounds in the Seas of India, China and the Malay Archipelago.

As an edible fish it is not considered of great import- 
ance. Small lots are occasionally sold in the Sydney Fish Markets; but if there were a ready sale for them large numbers could, at times, be obtained. It attains to a length of 15 or 16 inches, but examples of about 12 inches in length are more commonly seen.

The Butter-Fish is very prettily marked. On a bright silvery background are displayed at intervals, broad, vertical, broken bands of a dark-green colour. These bands are composed of large elongated spots. Between these are shorter and narrower bands composed of sinaller spots.

Another fish of this family that may be mentioned, is the Spotted Butter-Fish (Liphippus argus).

\section{THE SURGEON-FISHES.}

(Family: Acanthuridce.)

THE fishes of this family are very remarkable, in that they, possess-in some instances-a curious, sharp, erectile, lancetshaped spine, on each side of the tail, which, when at rest, is set in a sheath; while in other cases there are one or more sharply-keeled, bony plates in the same position. By means

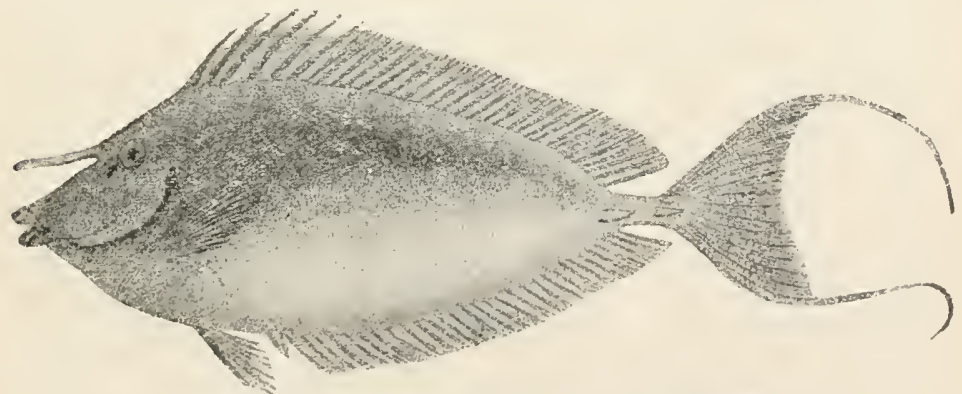

Fig. 51.-UNICORN-Fish (Naseus unicornis).

of these spines or knife-like plates, these fishes are able to inflict a very nasty wound upon the unwary-by striking suddenly from side to side. In very young specimens these spines or plates are usually wanting.

In appearance, one of the most remarkable of these is the Unicorn-Fish (Naseus unicornis). This is a very 
wirlespread species; and amongst other localities, is occasionally obtained on the Queensland coast. On its grotesque-looking head immediately in front of the eyes, it possesses a curious horn-like projection. which is sometimes as much as 2 inches in length. The fish itself attains a length of upwards of two feet.

The principal Surgeon-Fish on the New South Wales coast, is that known as Prionurus microlepidotus. It is one of those species possessing the row of keeled plates on each sicle of the tail, and is rather a funereal-looking fish, being of a uniform dark colour-almost black. This fish is a rock-dweller and subsists largely on gelatinous seaweeds. It is occasionally taken by hook and line in the vicinity of Sydney Heads, but is more-usually captured in the trammeinet.

It reaches a length of about is inches.

\section{THE "BLACK TREVALLY" FAMILY.}

(Family: Siganide)

OF this family about 30 species are known from various parts of the Indian and Pacific Oceans. They are all characterised by the possession of a strongly-compressed obionm body, covered with very small scales, and may be readily recognised by the singular structure of the fins. In all of the species, the dorsal fin has 13 spines and Io rays; while the anal fin has 7 spines and 9 rays. It is well to make a note of this, as it is of great assistance in recognising these forms. The ventral fin has a very curious structure indeed, possessing an inner spine as well as the outer one usually seen in fishes, with three soft rays in between. All the spines of these fishes are very acute: and wounds inflictel with them have been found to be very painful. This applies equally to the species found along our own coastline.

All of these fishes are vegetable-feeders and they are nearly all of small size. 
Amongst those which are found on the east coast oi Australia may be mentioned the fish known in New South Wales as the Black Trevally (Siganus ncbulosus). This: is a small fish of from 8 to Io inches in length, which. though not often captured, occasionally occurs on parts of

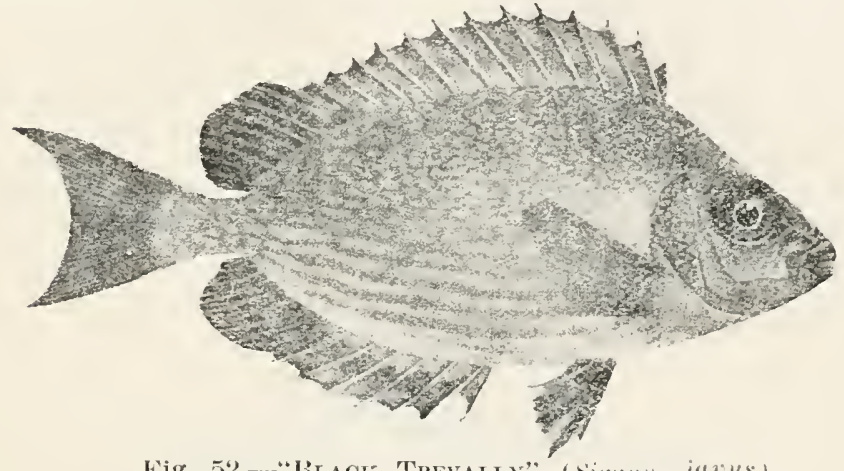

Fig. 52.- "Hlack Trevally" (Nigumu, jumus).

the New South Wales coast in fair numbers. Though callerl "Black" Trevally, this species is of a brownish colour, with irregular marbled mottlings all over the body.

A closely-allied species occurring on our coastline, is Siganus javns. This is the one here illustrated.

\section{THE POMACENTRIDS.}

(Family: Pomacentride.)

THESE are small marine fishes frequenting tropical and temperate seas. According to Boulenger over i 50 species are known. Most of the species have a very brilliant colouration. Some live upon small marine animals, while others subsist upon vegetable matter. A number of species occur along the coast of Queensland, particularly in the neighbourhood of the Great Barrier Reef and a few are found in other States of the Commonwealth. None of the Australian Pomacentrids are at present of much economic value, but some of them have very curious and interesting habits. 
Perhaps the most interesting to us, arc the curious little Amphiprions, some of which actually live within the mouths of some of the giant Sea-anemones, regardless of the stinging tentacles of the latter, which, it may be added, apparently have no effect upon these remarkable fishes, while bodies of animals of the same or a larger size are constantly seized by them and devoured.

In this connection it will be of interest to quote SavilleKent's words, in his work on the Great Barrier Reef ; where, in speaking of the two giant anemones Discosoma kenti and Discosoma haddoni (the former of which reaches a diameter of about 2 feet, while the latter is not much smaller) he says:

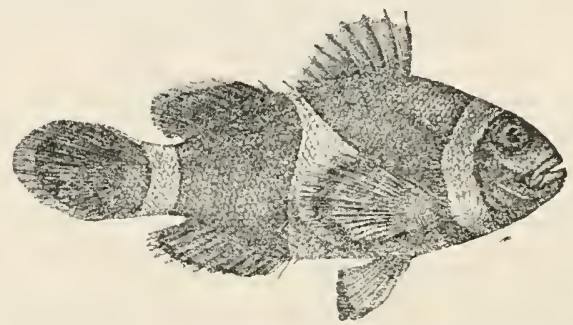

Fig. 53.-AMPHiprion (Amphiprion percula).

"A phenomenon of high interest is associated with the two giant anemones just described. Both of them, in point of fact, act the part of hosts to other living organisms of appreciable size; the guests comprising two species of fish, and also a species of prawn. The larger species, Discosoma kenti, almost invariably contains two or more specimens of a percoid fish about three inches long, that is identical with the Amphiprion percula of Lacepéde. On thrusting a stick into the oral orifice of the anemone, the fish swim out, but return immediately to their residence within the gastric cavity of their host on the removal of the disturbing missile. The fish thus furnished with free lodgings by the anemone, is notable for its brilliant colouration. The ground colour in this type is a bright orange-vermilion, interrupted by three pearly-white cross-bands, which, as well as the edges of the fins, are bordered with black. . . The second species of fish, Amphiprion bicinctus, that similarly lodges with Discosoma haddoni, but dines out, presents the same orange- 
vermilion ground colour, but possesses only two white crossbands, and neither these nor the fins are edged with black.

.. In a third species of this genus, apparently identical with Amphiprion melanopus, collected by the author at Port Darwin, there is only one intersecting band of white; and. as this crosses the fish's head and cheeks it communicates to it the ludicrous appearance of having its face bandaged as though for toothache. At first sight it was, as a matter of fact, imagined that a scrap of white paper was accidentally adhering to the fish, and it was only on attempting to remove it that it was recognised as forming an integral part of the organism."

\section{THE PARROT-FISHES OR WRASSES.}

(Families: Labride and Scaride.)

As these two families are so closely allied, it seems to me desirable to treat of them together. They form an immense group of over 500 distinct species. In the words of Giinther: "The 'Wrasses' are a large family of littoral fishes, very abundant in the temperate and tropical zones, but becoming scarcer towards the Arctic and Antarctic circles where they disappear entirely. Many of them are readil. recognised by their thick (fleshy) lips, which are sometimes internally folded; a peculiarity which has given to them the German name of 'Lip-fishes.' 'They feed chiefly on mollusks and crustaceans, their dentition being admirably adapted for crushing hard substances. Many species have a strong curved tooth at the posterior extremity of the intermaxillary, ${ }^{*}$ for the purpose of pressing a shell against the lateral and front teeth; by which it is crushed. Other Wrasses feed on corals, others on zoöphytes; a few are herbivorous." Most of those glorious-looking many-hued creatures, to be seen in the vicinity of the coral-reefs; swim-

* One of the hones of the upper jaw. 
ming in and out amongst seaweeds and growing coral, are nembers of this great group of fishes.

Of the numerous Australian Parrot-fishes or Wrasses, 1 might dwell a little upon the following more important edible kinds:-The Pigfish (Diastodon unimaculatus), the Groper (Acharodus gouldii), the Maori or Rainbow-Fish (Coris lineolatus), belonging to the Labridee proper, and also the so-called Rock-Whiting (Odax richardsonii) and the Herring-Kale (Olisthops cyanomclas) belonging to the Scarida. All of these are "Rock-Fishes," properly socalled, as they frequent weed-covered rocks in the vicinity of the headlands and sunken reefs. All-or nearly all-of them, may be captured by hook and line, but the most effective means of capture is the trammel-net.

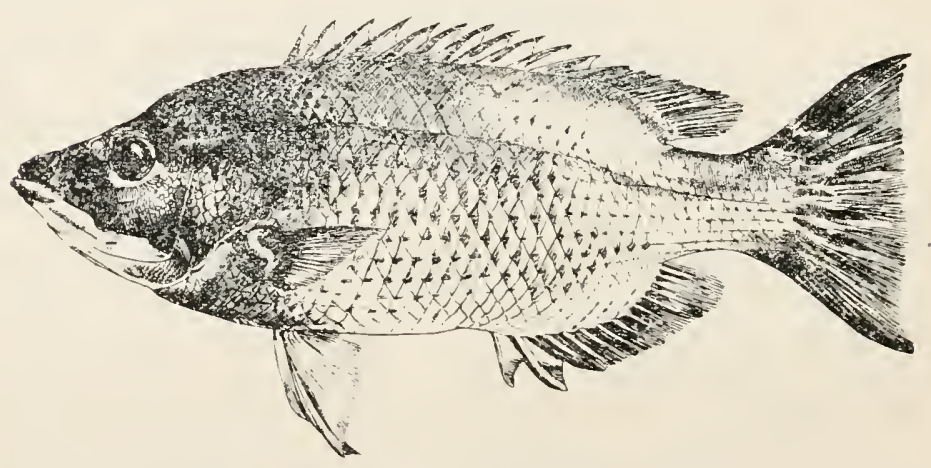

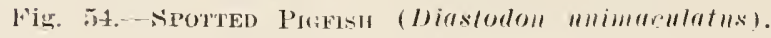

The Pigfish is well-known on the New South Wales coast. It has also been recorded from both 'Tasmania and New Zealand. From an edible standpoint it is a very fine fish, being much sought after by those who know its value. Its common name has been derived from the very suggestive. pig-like snout. The lips are fleshy and thick. From the description of the colours given below it will be seen that this is a most beatuful fish. The description, which is after Ogilby's, is a faithful one, true to life.

The body is a deep scarlet above, gradually changingr into pink or saffron yellow below. Each scale has on the sides a narrow reddish streak in the middle, this giving the fish a longitudinally-banded appearance. There is a large 
pinkish patch below the origin of the soft portion of the dorsal fin, and some small spots of a similar colour in front of it on or near the lateral line. The dorsal and caulal fins are scarlet, with a fairly broad lighter margin; the former with a large dark-blue spot between the 6th and 8th or $7^{\text {th }}$ and gth spines; this being surrounded, except at its base, by a pearly-white band. The anal fin is scarlet towards the front and yellowish behind. The ventral fins are hyaline with the outer rays golden. The pectoral fins are reddish, with a small dark blue spot-inside, at the base. In each eye, the iris is a beautiful orange tint.

The fish known as the Banded Pigfish (Diastodon bellis) is most probably not a distinct species, but merely a colour variety of the Spotted Pigfish; which, it may be alded, is the nore common form.

According to my experience, the Spotted Pigfish grows to a leugth of about 15 inches.

The Groper: By this name I particularly refer to what is called the "Blue" Groper; though there appears to me little doubt that the only difference between it and the so-called Red or Brown Groper is that of sex; the former heing normally the male. while the latter is the female.*

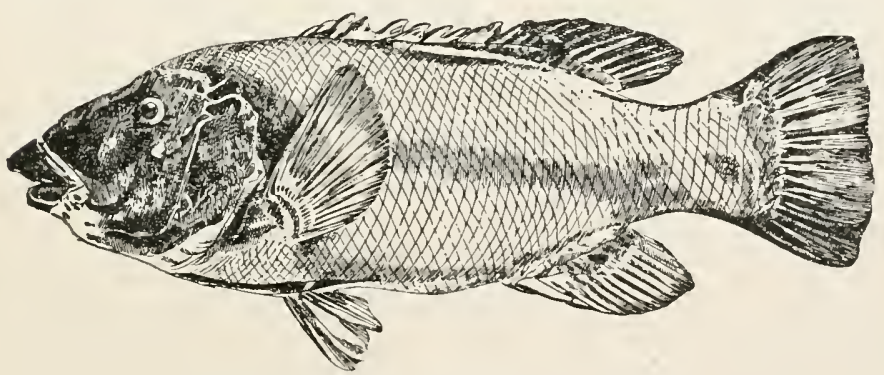

Fig. 55.--GROPER (Achcerodus gouldii).

Supposing that this is the case, the finding of an occasional male dressed in red or of a female dressed in blue, would not upset the idea; as, instances in the Animal Kingdom, in which the female has assumed the livery of the male, or vice versâ, are not uncommon. I have found this to be

"I never yet saw a young "Blue" Groper that was blue, the ground colour being always a reddish-brown. 
partially so in the case of the Herring-Kale; mentioned later on.

The Groper is found abundantiy along the coast of New South Wales, as well as that of Victoria and of Tasmania. As a market fish it is not very common, not being very highly esteemed, from an edible point of view; in larga specimens the head and shoulders only, being usually consumed. Nevertheless, small examples up to 2 pounds in weight are excellent fish for the table.

The Groper may be captured by hook and line; :1 common bait being the body of a crab, after the spot where fishing is being carried on, having been well "berleyed" with crabs' legs and other "delicacies.'

This species is a very ponderous-looking fish and it is one of the largest of the Wrasses, growing to a length of from 3 to 4 feet.

The Maori, probably so-named on account of the peculiar tattoo-like colour-markings on each side of the head, is a common New South Wales rock-fish, being known to occur also, in Victoria. South Anstralia and Western Australia. To what extent it abound, in the three last-mentioned States is at present a matter of some doubt. It is a much smaller species than the last-mentioned and of a totally-different appearance; possessing a more elongate, compressed body-attaining a length of about 16 inches. As an edible fish it is of some value, and examples are to be seen in the principal fish markets of New South Wales, throughout the greater part of the year. It is easily captured by means of hook and line; an animal bait, such as shell-fish, crustaceans or fish being used. Young Maoris are captured in numbers on the small-boy's line, around weedy rocks in the lower parts of our inlets. The verydistinctive colours of this species, render it easily recognisable.

The general colours are: red above, yellowish below; separated by a more or less conspicuous, pink, longitudinal band, which is generally bordered above and below by purplish bands. All the lower scales have a violet bar. Together they form more or less regular vertical streaks. The upper and lower surfaces of the head are an olive-green, 
with the sides golden; the whole being traversed by blue bands, which are broadest below. The dorsal fin possesses four narrow, longitudinal, violet bands, and small spots of the same colour between them; there being an olive-green biotch between the second and third spines. The anal fin has over its surface, irregular rows of violet spots separated by golden bands. The pectoral and ventral fins are without spots, but the caudal fin has violet bars between the rays. The eyes-with the exception of the pupil-are crimson.

The Rock-Whiting is not a Whiting, in the proper sense of the word, as restricted to our Australian Whitings of the family Sillaginide (page Iog). Considering that the latter and the fish under discussion belong to two totally different families, having but little in common with one another, it is really remarkable that such a bodily likeness should exist (though, at the same time, it has to be remembered, that such an occurrence is by no means unique in the Animal Kingdom, instances of even close mimicry between animals of a very different nature being often met with; particularly in the class of insects ; where one occasionally finds that insects in entirely different orders, for purposes either of protection or aggression, are modified so curiously as to make them resemble closely each other externally). From the Whitings proper, the Rock-Whiting may be at once distinguished, by the softer and more slimy feeling of the body; due to the less horny nature of the scales; the lesser number of body-scales, which are consequently relatively larger; the teeth, which in this species are formed into a kind of rough plate having a chisel-like edge, while in the true Whitings they are small, separate and chiefly villiform; and, finally, by the arrangement and structure of the fins. In the true Whitings there are two distinctlyseparated dorsal fins, the first being fairly short, high, somewhat printed and spinous: while the second is soft, low, and possesses a greater base-length. In the Rock-Whitıny there is only one dorsal fin; this being long and low and of an almost uniform height throughout. Though more than half the length of this fin is composed of spinous rays, the 
latter are soft and flexible-as are all the other fins of this fish.

The Rock-Whiting is quite common along the shores of New South Wales, Victoria and Tasmania, while in South Australia and Western Australia it is also known to abound. In New South Wales it is more common in a southerly direction, the waters of Victoria being, apparently, its principal home. In Victoria and Tasmania, this fish is known as "Stranger"; this name even being occasionally used in the Sydney markets.

This species is commonly obtained of a length of 12 to I4 inches, though larger specimens are obtainable.

It is carnivorous-if not wholly, very largely so--subsisting principally upon small marine mollusks, crustaceans and other organisms to be obtained in the vicinity of, or amongst, weedy rocks at sea.

In colour there is a good deal of variation, but the following description, which is adapted with slight modifications from that of Ogilby, may be taken as fairly typical: Above purple or reddish-brown, darkest on the head. The sides are of a bright greenish-blue, the lower surfaces bluish-white, the whole being profusely spotted with orange, and, usually, with indistinct, darker, transverse bands. The cheeks are greenish-blue, beautifully vermiculated with orange. The spinous portion of the dorsal fin is a palegreen (sometimes blue), the basal half being unspotted, while the marginal half is crossed by narrow, oblique, orange or lilac bars. The soft-rayed or hinder portion of the dorsal fin possesses a large blackish spot, often broken up into several smaller spots, occupying the greater part of the base; there being a broad, purple, marginal band spotted or streaked with orange. The anal fin is violet with purple and orange spots. The ventral fins are whitish, tipped with purple and having large orange spots near the base. The pectoral fins are greyish and the caudal is a greenish-blue with orange spots.

From the above description it will be at once apparent that this species is a very beautiful fish; and such is certainly the case.

Before leaving this fish. I must mention that there is 
a very much smaller kind of Rock Whiting which inhabits our waters. This is a, comparatively, dull-coloured little fish, growing to only a few inches in length and being found more commonly amongst weeds or rocks near the entrances to our inlets. This species is the Little Rock-Whiting (Odax baltcatus), known in Tasmania as the Kelp-Fish.

The Herring-Kale : This is one of the commonest of New South Wales and Victorian "rock-fish," being found also in Western Australia.

There are two forms of this species; the one being a dark blue-black, while the other is of a rich reddish-brown with beautiful orange and blue mottlings all over the body. The former is the male, and the latter is the female (this being, also, usually the larger). Some time ago it was thought that these were distinct species; and, in fact, they were described as such; but, that idea was found to be incorrect.

Though the dark colour spoken of is the proper livery of the male sex, I have seen and handled one large specimen of a male which possessed all the colours of the female.* But this is of very unusual occurrence.

The Herring-Kale abounds in similar situations to those inhabited by the Rock Whiting but is, perhaps, more common, than the latter. It is seldom taken by hook and line; one reason being that it is, generally speaking, of a more herbivorous nature; subsisting largely upon gelatinous seaweeds.

As an edible fish, this species possesses considerable value, being of good flavour and consistency. Only a better knowledge of its edible value is awaited, to ensure its consumption as food, on a very much larger scale than at present; and the supply-both present and prospective-is practically without limit.

In the capture of this fish, the proper gear to employ, is the trammel-net.

The Herring-Kale grows to a length of about 18 inches.

The following fuller description of the colours in each sex will be found of value: In the male the body is of a uniform

* This specimen is in the collection of the Department of Fisberies, New South Wales. 
bluish-black above; and a little lighter below. 'There is a bright blue band near the outer margin of each caudal lobe. and a similar one on each side near the upper margins of the pectoral fins. In the female, the body is of a rich brown, being lighter below. All of the body-scales have a narrow orange margin and a dull bluish central spot. The head, above, is blackish, the sides having orange and bluish vermiculated bands; below, greyish, with large orange spots. The dorsal and anal fins are reddish-brown, the former with faint olive-green spots, the latter with zig-zag orange bands. The ventral and pectoral fins have the rays blue, the last-mentioned having three blue cross-bands. The caudal fin is reddish-brown with irregular cross-bands. 
Chapter Vili.

The Yellowtail Family-The Sergeant-Fishes-- The Mackerel Family - The Barracouta Family.

\section{THE YELLOWTAIL FAMILY.}

(Family: Carangide.)

THIS is a large and important family of carnivorous fishes, containing many species of economic value, spread out over the temperate and tropical seas of the world, and nearly all are voracious fishes, while a number of them are swift and powerful swimmers, growing to a large size. About i50 species are known. They are characterised in a general way by the possession of a more or less compressed-often greatly elevated-body, which is either naked or covere!1 with small scales.

The Yellowtail family is well-represented in Australian waters, there being at least 12 species in New South Wales alone.

Amongst the Australian kinds might be mentioned, the Yellowtail (Trachurus declivis), the King-Fish (Seriola lalandi), the Trevally (Caranx georgianus), the SamsonFish (Seriola hippos), the Tailer (Pomatomus saltatrix), the well-known Pilot-Fish (Naucrates ductor) and the curious Pennant-Fish (Alectis ciliaris).

The Yellowtail is an almost cosmopolitan fish; being distributed over nearly the whole of the seas lying within the temperate and tropical zones of the northern and southern hemispheres. In Great Britain, where it is abundant, it is known commonly as the Horse Mackerel-a name which we in Australia apply to a member of the true Mackerel family (page $\mathrm{I} 60$ ). Though the Yellowtail is very abundant along a great part of the Australian coastline, and is, when fresh, of good flavour, it is not used much for food: most of those caught-chiefly immature fish-being used as bait by line-fishermen for the capture of larger or 
nore highly-prized fishes. Young Yellowtail-up to a few inches in length-simply swarm in the various inlets along the coast of New South Wales, at all seasons of the year. Adults are seldom seen in any quantity, as they keep more to the outside waters. Very young fish, from about three. quarters of an inch in length up to about 2 inches, are very often to be found in summer time in our harbours swimming in little shoals beneath (or behind as it often is) the friendly shelter of the "umbrellas" of Medusce of various kinds; particularly the common light-blue "Plubber" that is seen in such immense numbers at times. This is a known habit of the species in other parts of the world and I have personally observed it repeatedly in the upper waters of Port Jackson.

Being carnivorous and highly voracious, the Yellowtarl is not very particular as to its food, provided that it is flesh of some kind; usually, however, it subsists upon fish fry, small crustaceans and mollusks.

In this species, the scales of the lateral line, are, for the greater part, large and plate-like; a number of them being sharply-keeled, the keel ending in a spine.

The length of the largest specimens usually seen on the New South Wales coast, is about I2 or 13 inches.

In New Zealand, where this fish is very common, it is often known under the Maori name of "Hauture." The name of "Scad," also, is often applied to the species in various parts of the English-speaking world.

When a few Yellowtail are examined, it will usually be found that in the majority of cases, the fishes are acting as a host to one of the parasitic isopod crustaceans. This crustacean (Meinertia imbricata) attains a length of considerably over an inch and inhabits the mouth of the Yellowtail; clinging on to the tongue. It finds its way into the mouth of the fish while it is in a pelagic or free-swimming state during its babyhood. At that time, there is a freelymoving tail portion and the legs show a greater amount of development; but after "settling down" in the mouth or the pharyngeal cavity of the fish, the tail portion of the crustacean hecomes dwarfed and stiff, while the legs become modified into sharp hooks which point inwards, facing one 
another, so as to enable it to hold on-which it does most tenaciously. Apparently the fish is not in the least "put out" by the intrusion of the parasite; as those affected are quite as healthy and vigorous looking as any of these without parasites.

The King-Fish, though not such a cosmopolitan as the Yellowtail, has an immense distribution. It is found along probably the whole of the eastern and southern coastlines of Australia, and, in addition, occurs in the waters of Tasmania, New Zealand, I,ord Howe Island, Japan, Cape of Good Hope and also in those of America from IVest Florida to Brazil. In addition to the one given above, it is known under various titles in different localities. In America where it is valued as food it is called Amber-Fish. AmberJack, or Coronado and in New Zealand, the Maori name of "Haku" is applied to it. Coming nearer home, we find that, as in a number of other species, the application of two different names to the one form in the two principal States of the Commonwealth of Australia, has given rise to a gooi deal of confusion. In Victoria it is usually known in the markets as "Yellowtail" ( just occasionally being heard of as "Sydney King-Fish"). Now the King-Fish grows to a length of about 6 feet with a weight of about 100 pounds; specimens of 4 feet in length being quite common; while, as before stated, the length of the largest specimens of Yellowtail usually seen, is about I2 or I 3 inches, most people being only familiar with the younger stages up to about 6 or 7 inches; the surprise and derision, then, of a New South Wales fisherman-not armed with the facts as here stated-when hearing of the capture along the Victorian coast of "Yellowtail" measuring 4 or 5 feet and weighing 50 or 60 pounds, may well be imagined. The "gentlemen of the rod" are not famed for their veracity, and such a story as this would appear to the majority as quite inexcusable. Yet this is only one of the smallest of the many difficulties arising out of the misuse of common names.

The King-Fish is a highly-voracious fish and a swift and powerful swimmer. It is of pelagic habit, moving about in enormous shoals, from which, large bodies often detach themselves, entering our harbours either in pursuit of 
smaller fishes like the Pilchard or to escape the attentions of Sharks and Porpoises, which play great havoc amongst them.

This species gives a considerable amount of sport to anglers. It is easily captured on a line trailed behind a moving boat, and, when hooked, makes a good fight before being safely landed.

Though no doubt in the future proper means will be found for the utilisation and disposal of this fish, at the present time it is not considered of much importance-comparatively speaking--from an economic point of view, as the flesh is not of such a good flavour as that of the majority of our food-fishes.

In colour, the body of the King-Fish is bluish or bluishgreen, above; with the sides silvery and the lower surfaces whitish.

The skin has a uniformly-smooth feeling, the scales being very small and numerous.

The Trevally: This is another widely-distributed fish. It is very common in the waters of New South Wales, Victoria, Queensland and Tasmania; being also abundant around the coasts of New Zealand, and Lord Howe, Norfoik and Raoul Islands. It has been also recorded from Western Australia. In Victoria it is known as Silver Trevally, while in New Zealand, according to Hector, it is known under the Maori name of "Arara."

Though to a certain extent a pelagic fish, and occurring at times in enormous shoals, this species is one of those that are always with us to a greater or lesser extent, in our inlets. It is very frequently to be seen in our fish markets, and, if in good condition, always commands a ready sale; as it is of considerable value as a table fish. Like others of this family, it deteriorates very rapidly after death, if high temperatures prevail; particularly so when, as is usually the case, it is not gutted. It takes the smoking process well, and at times large numbers are preserved by this means.

As regards size; the ordinary "run" of what might be termed large Trevally, average about 2 to 3 pounds in weight, though examples of a much larger size than that are obtainable. During November. 1905, when a consider- 
able quantity was coming into the Sydney fish markets, some of the specimens ranged about 6 or 7 pounds in weight, examples of 8 and one of 9 pounds being recorded-the length being about 2 feet 6 inches.

Young Trevally are found in great profusion in all the coastal inlets of New South Wales, being also, often found at sea. They are prettily ornamented with transverse bars of a golden-yellow tint. They, with the adults, are very beautiful when freshly taken from the water; the whole of the body, particularly the upper portions, showing the most glorious iridescent reflections.

The body-scales are very small; those of the hinder portion of the lateral line being enlarged and produced outwardly so as to form a horny ridge on each side of the tail; there is but little approach, however, to the tremendous development of the lateral-line scales as seen in the Yellowtail.

The Samson-Fish: So far as present records go, this fish is a native of New South Wales only; though it is scarcely probable that a fish of pelagic habits, as is this, will not be found to extend beyond the limits of this coastline.

Though at times this species roams about in very large shoals, but a comparative few find their way into consumption as food.

It may be taken by hook and line in the same manner as the King-Fish, to which it is closely allied.

The "Samson" is a beautiful fish, the sides being of a fine golden-yellow; with irregular, wide, vertical bars of a darker colour; these being still more pronounced in the young. The very young fry of about 2 to 3 inches in length is coloured with a gold as rich as that of an ordinary Goldfish.

This fish grows to a length of at least twenty inches: most of the large ones captured, however, are considerably below that size.

Amongst allied forms, this species may be at once recognised by its prominent "bull" head.

The Tailer: Here we have another fish of wide distribution. It is found in the Atlantic, Pacific and Indian Oceans, finding its way occasionally into the Mediterranean 
Sea. On the Atlantic coast of America it ranges from Central Brazil and the Guianas, through the Gulf of Mexico and north to Nova Scotia-though never seen in the Bay of Fundy. It occurs also in the Malay Archipelago, at the Cape of Good Hope, at Natal and about Madagascar. In America it is generally-familiar under the title of "Bluefish," while in South Africa the name of "Elft" or "Elftvisch" is applied to it. In Australian waters, this important food-fish is very common along the coasts of Queensland, New South Wales, Victoria, South Australia and Western Australia, being also found in 'Tasmanian waters, though it does not appear to be so abundant there. Though adult Tailer (or Tailo:) are adapted for roaming over large areas of water-and do so-the young are found in great profusion in many of the inlets embraced within its habitat. Particularly is this so in Port Jackson, where large numDers of immature examples are enclosed in almost every haul of the "garfish"-or "hauling"- - net. Even in the inlets themselves, the young often mass themselves together so as to form large shoals, particularly when small fishes like the young of the Pilchard are present in great quantities. Amongst these the young Tailer, trying to emulate their older relatives, play great havoc. When the Tailer are roaming about in the harbour of Port Jackson in shoals, hundreds of men and boys line the wharves; all endeavouring to entice the fish to take their bait; which is not a very difficult feat to accomplish, as a Tailer is usually too hungry to stop to see whether there is anything attached to the bait. Shoals of the full-grown fish also often make their appearance in the harbours, but, as a rule these prefer the open sea. However, the adults are nearly always present-either singly or in small groups-in the harbours and lakes. In Port Jackson and other localities when a net is hauler ashore, not uncommonly half a mullet will be picked out of the net; usually the head part. When one sees this he knows that "Master 'Tailer" has been busy; for, it is a habit of this fish, that when he cannot take in the whole of a fish he takes as large a portion as he can comfortably-or, perhaps, uncomfortably-swallow: snapping it off with his wonderful steel-trap-like jaws. It is a most absorbing and 
interesting sight to see 2 or 3 Tailer "rushing" a small shoal of Mullet on, say, a shallow, sandy flat. They race along with almost lightning speed, sweeping round now and again in the most graceful curves, cleaving the water at the surface with their blue backs and sending the little ripples and erldies away on each side of them. Though at times great numbers of large fish could be captured by our fishermen, no special fishery for this species yet exists on our coast; the principal reason being that the fish decomposes so rapidly after death, this rendering it what is called a "bad fish for market." This is very regrettable, as a ireshly canght and cooked Tailer is of fine flavour and fit to grace the best tables. At the present time, the average fisherman feets rather aggrieved if a few Tailer are enclosed in his net, as they have a troublesome habit of rushing the net, snapping at it with those awful jaws and making holes to let themselves and other fishes out.

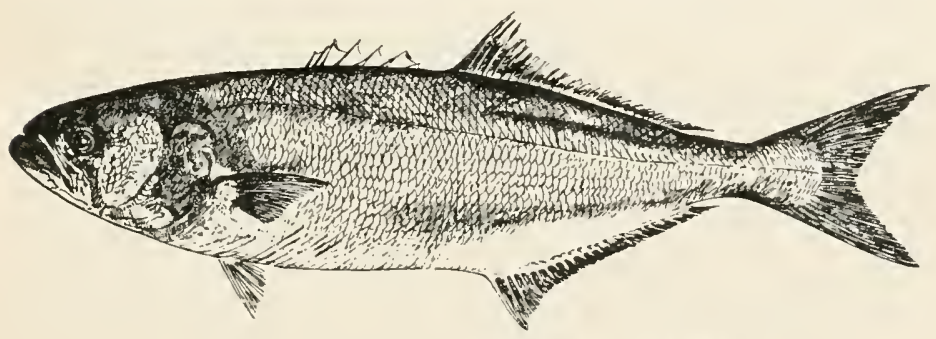

Fig. 5f.-TaIter (Pomatomus saltatrix).

As a smoked fish the Tailer is "really excellent," that being the universal opinion; and from an economic point of view undoubtedly there is a great future before it. In the United States of America at the present time, great quantities are captured and sold, either in a fresh condition or preserved in a smoked or pickled state; the amount consumed annually in the country mentioned being very considerable.

During I.9oI, the quantity of Tailer captured in the six Middle-Atlantic States of the United States of America reached the enormous total of I6.3I7,795 pounds (valued it about $\left.f_{1} \mathbf{5}, 600\right)$; that of the State of New York alone being $9 \cdot 350,502$ pounds. 
In Victoria and Western Australia this fish is known as "Skipjack," while in Queensland, the native name of "Pombah" is sometimes used.

It grows to a length of about 3 feet.

The following interesting notes in regard to the habits of the species under consideration are from Jordan and Evermann. They speak of it, of course, as the "Bluefish," and say:-

"The bluefish is a carnivorous animal of the most pronounced type. As Professor Baird has well said, there is no parallel to the bluefish in point of destructiveness, to the marine species on our coast. It has been likened to an animated chopping-machine, the business of which is to cut to pieces and otherwise destroy as many fish as possible, in a given space of time. Going in large schools, in pursuit of fish not much inferior to themselves in size, they move along like a pack of hungry wolves, destroying everything before them. Their trail is marked by fragments of fish and by the stain of blood in the sea, as, when the fish is too large to be sivallowed entire, the hinder portion will be bitten off and the anterior part allowed to float or sink. It has been even maintained, that such is the gluttony of this fish, that when the stomach becomes full, the contents are disgorged and then again filled! It is certain that it kills more fish than it needs or can use. The amount of food they consume or destroy is incredibly great. It has been estimated at twice the weight of the fish in a day, and one observer says that a bluefish will destroy daily a thousand other fish. It has been estimated that there are annually on our coast from New Jersey to Mononomy a thousand million bluefish averaging 5 or 6 pounds each in weight, and that these eat or destroy at the lowest estimate ro fisli each every day. And as the bluefish remain on this coast at least 120 days, the total destruction amounts in round numbers to twelve hundred million millions of fish destroyed in a single season by this species. These would weigh at least three hundred thousand million pounds. And it must be remembered that in this estimate no account has beein taken of those destroyed by bluefish under 3 pounds in 
weight, vastly more numerous and all engaged in the sanle butchery."

Further these same anthors write: "The bluefisl is one of the most active and nnyielding fishes that swim. 'It can jump higher and come down quicker, dive deeper, and stay under longer than any other salt-water fish of its size, says Nimrod Wildfire. 'Took at his clean build, and it is accounted for; his narrow waist and depth of hull, falling off sharply as it approaches the keel, enabling him to keep well to windward, as if he had his centreboard always down. See his immense propeller behind! No fish of his size is more wicked or wild when hooked." "

All of the above-quoted remarks are equally applicable to this fine fish as it occurs in Australian waters; and I trust that these notes will assist in directing more attention to the utilisation of such a valuable food-fish.

The Pilot-Fish This highly-interesting fish, which has a cosmopolitan distribution, is a frequenter of the open seas rather than the harbours. Though it occurs in some parts of the world in sufficient abundance to be utilised as a food-fish, generally-speaking it is chiefly known through its habit of consorting with the large predaceous Sliarks. And true it is that nearly every large Shark has a small company of these Pilot-Fishes in attendance wherever it goes. Many are the marvellous tales of the manner in which the little fish pilots its mighty and fearsome companion into the regions of food and out of the regions of danger; and most of them should be taken cum grano salis. But whatever happens to the Shark as a consequence of the "Pilot's" attendance there is no doubt that the latter is there from purely selfish reasons-if I may ptit it that way-subsisting upon the morsels which are so small as to be beneath the Shark's notice and also upon excrementitious matter from the Shark itself. In addition to this, the Pilot-Fish must experience a certain amount of immunity from the attack of fishes larger than itself, which are over-awed by the presence of the Shark. Though, personally, I would not trust a hungry Shark, there appears to be no doubt that it does not usually molest its small companions; in fact, if it were otherwise this interesting partnership could 
hardly have been developed. It has been suggested that the Pilot-Fish is even attentive enough to remove skin-parasites from the Shark.

The Pilot-Fish is of a bluish colour, with dark vertical bars. It attains a length of about 2 feet.

The Pennant-Fish is a very widely-distributed species of small size. In addition to its occurrence upon various portions of the Australian coastline, it is found in the Red Sea, the Seas of India and the Malay Archipelago and also on both coasts of tropical America, being common about Floricla Keys and Cuba, where it is a food-fish of some importance. As it is of rather rare occurrence in the Australian portion of its habitat, it is of no economic importance.

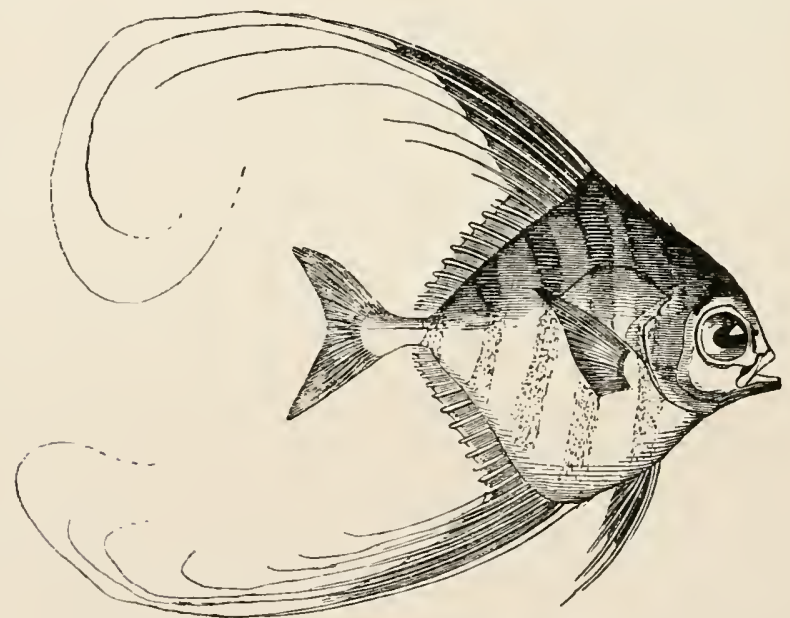

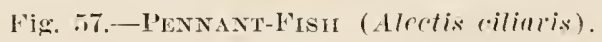

This curious-looking fish, with its high, compressed, somewhat "diamond-shaped" body, is chiefly remarkable for the long filaments which depend from the dorsal and anal fins. The dorsal filaments are often as much as four times the total length of the fish itself, while those of the anal fin are not much shorter; and when the Pennant-Fish is swimming slowly and majestically through the water they lend to it a very peculiar aspect. 
The body is of a brilliant silvery colour and has 6 or 7 dark vertical bands upon each side.

The tail is very deeply forked.

In America this species is usually known as "Cobbler Fisli" or "Thread Fish."

\section{THE SERGEANT-FISHES.}

(Family: Rachycentrida.)

As far as is at present known, this family contains but one species-the Sergeant-Fish (Rachyccntron canadus). This species is an inhabitant of most warm seas, being very widely distributed. It is not very uncommon on the New South Wales coast and is also obtained in Queensland. In shape it is elongate, and it is covered with very small smooth adherent scales. The head is broad and low; the bones above appearing through the thin skin. It is a large, strong and voracious fish attaining a length of at least 4

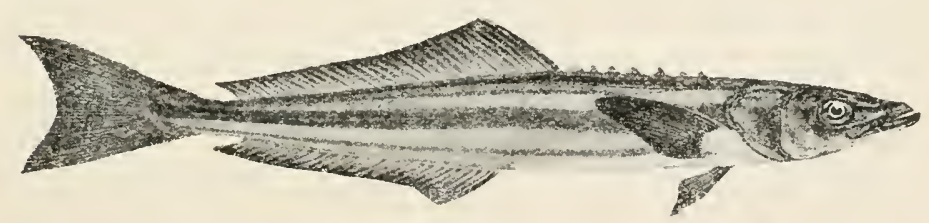

Fig. 58.-... Sergeant-Fish (Rachllcention canadus).

feet. In colour it is of a light brown; darker above and somewhat inclined to greyish below, and possessing along each side, a broad chocolate-coloured band, with, usually, a narrower one beneath. It is the possession of this broart stripe which has given rise to the name of "Sergeant," applied to this fish. In addition to the name stated, this species is also known under various others, such as WestIndian Kingfish, Crab-eater, Coal-fish, etc., the last two being given to it on the coasts of the United States of America, where it is considered as an edible fish. 


\title{
THE MACKEREL FAMILY.
}

\author{
(Family: Scombride.)
}

From 50 to 60 species of this family are known from various parts of the world, about 8 of which are to be found in Australian waters. These fishes are amongst the swiftest inhabitants of the sea. Elegant in form (and often in colour) their beautiful spindle-shaped bodies are able to gracefully cleave the waters with but little muscular exertion. 'Typical "submarines," they are able to make their way in the water, in any direction, and at any angle, with a speed that is surprising. If a typical Mackerel be closely examined, it will be at once apparent that the fish has been "built for speed." The skin is smooth and slippery, the snout is pointed and somewhat conical in shape, and th: body tapers away rapidly to the shaft of the tail, from which the comparatively-large, forked caudal fin spreads out. Upon examining the back we find that there is a groove which enables the first dorsal fin to lie right down out of sight and that the second dorsal and anal fins are partly sheathed and arranged in such a way that there is little resistance to the water. Even the pectoral and ventral fins also, fit into shallow depressions in the body; so that when the fish is travelling at a high rate of speed, a clean, smooth, non-resistant surface is presented, this allowing the fish to literally "slide" through the water; so that with a minimum of effort a very high rate of speed is attainable. Upon the tail in certain Mackerels there is a kind of leathery keel developed on each side, followed by two other smaller ones-one above it and one below it-on the somewhatflattened root of the caudal fin itself; while in others only the latter are developed. The purpose of these is to assist in giving a little stability to what would otherwise be a "very cranky craft" when the balancing fins are laid back. Of course, when the fish is only travelling at a low rate or moving about within a small area the pectoral, ventral, dorsal and anal fins are continually in use. I should also have mentioned that the little "finlets" which follow after 
the second dorsal and anal fins and which are so chara:teristic of the Mackerel family, are of very material assistance to the fish in giving additional stability, and because they, apparently, act as so many tiny rudders.

With certain modifications (because of the tail being here the means of propulsion), what a glorious living pattern is this for future high-speed submarine boats!

The members of the Mackerel family are of exceedingly-great importance to Man (though if one were to judge by the little use at present made of them in Australian waters, he would not be likely to come to that opinion). immense numbers being captured and consumed as food. Most of the species are large and powerful fishes. Some of the most important, however, are of a fairly small size, making up for that-as in most of the Herring family-by the enormous size of their shoals. The Common Mackerel of Europe and the Atlantic coast of North America is one of the latter. It is at present one of the most important among all food-fishes; providing-in its capture and treatment alone-employment for thousands of persons. Probably the largest numbers are captured on the coast of Norway, while the British fishermen reap a rich harvest out of them; but the fact that in Igoo the catch landed at Boston and Gloucester alone-two ports on the coast of the United States-amounted to $24,854,794$ pounds, valued at about $£ 250,000$ sterling, slıould demonstrate the importance of this fish. Amongst the larger forms-in fact, the largest-is the great Tunny (Thunnus thynmus), which attains to a length of over Io feet and a weight of I500 pounds. One gigantic example captured off Cape Ann in America even measured I 5 feet. This fish has a wide distribution, occurring in nearly all-if not all-warm seas. It is highly probable that it will be found to occur at times in numbers, on the coast of Australia. In the Atlantic Ocean, on the American coast, it is found as far north as Newfoundland and the Loffoden Islands. It is also abundant in the Mediterranean Sea, and in the Pacific Ocean on the coast of California, while, in addition, it has been obtained in the Indian Ocean and on the coast of Japan. In the Mediter- 
ranean Sea-where a great fishery for the species existsand on the coast of California, it is known as the "Tuna";* or, perhaps still more familiarly as the "Leaping Tuna"; while in England it is always known as "Tunny." The fishery of the Tunny is systematically carried on in the Mediterranean, dating from remote antiquity. Its salted preparation was known to the Romans as Saltamentum sardicum, being greatly esteemed by them. The flesh is still largely consumed as food. In the Mediterranean Sea its capture is effected almost solely by the use of deep floating-nets; but in California, it is recognised as a great sporting-fish; consequently being greatly sought after with rod and line. Many are the tales of the prowess of this great and powerful fish. The American atthors, Jordan and Everman11, quote Professor Charles F. Holder, who says that: "The most sensational fish of these waters" (Californian) "is the leaping tuna, which well compares with the tarpon; and, personally, I prefer it to its Florida and Texas rival; and, in my experience, the average large tuna is a match for two tarpons of the same size. The tuna is the tiger of the Californian seas, a living meteor which strikes like a whirlwind, and when played with a rod that is not a billiard-cue or a club in stiffness, will give the average man the contest of his life."

Amongst the members of the Mackerel family which are known to be found in Australian waters, may be mentioned the Mackerel(Scombcr colias), the Horse-Mackerel (Sarda clilensis), the Bonito (Gymnosarda pclamis), the Albacore (Germo alalunga), and the two species of Spanish Mackerel (Scomberomorus commersonii and S. guttatus).

The Mackerel of Australia is a fish of considerable value, and is likely to become of great use as a food-fish in the near future. Extensively and abundantly distributed in our waters, only a little enterprise is needed to raise it to a position of great importance amongst our economic fishes, at the same time creating a fishery of boundless extent. Always present in our waters, at certain times it swarms along our coastline and in our harbours and

* In New Zealand a species of Eel is known as "Tuna." 
estuaries in countless myriads. Many of those that enter the inlets are immature, the larger fishes usually preferring the open waters of the ocean itself, though occasionally large shoals of those also put in an appearance. In addition to being distributed over the greater part of the Australian coastline, this species has an immense range, occurring in the waters of Europe, and on both coasts of America, being particularly common in the Mediterranean Sea and in Southern California. In America it is known under various titles, such as Chub Mackerel, Tinker Mackerel, Easter Mackerel and Thimble-eyed Mackerel; while in England it is called "Spanish Mackerel."*

In colour the Mackerel is as follows: Upper surfaces bluish-green with numerous, irregular, wavy, blackish streaks, which extend to just below the lateral line. Some of these streaks form reticulations and enclose pale spots of the colour of the back. Belly and sides silvery-white, but always, in the adult, with roundish dusky spots or cloudings. There is a black spot on each side, at the root of the pectoral fin.

As a game fish this species is somewhat sought after, as it gives a considerable amount of sport to line fishermen. The Mackerel usually attains a length of from is to If inches.

The Horse-Mackerel: This active and highly-voracious fish is not so commonly seen as the preceding, but at times, huge shoals put in an appearance on the coast of New South Wales, and it is also known from the Victorian coast. As it has an extensive distribution outside of Australia it is more than probable that it is to be found in the waters of other Australian States, though it appears to have escaped attention so far. It attains to a very much greater size than the Mackerel, growing to a length of about 3 feet. Ogilby says that "with us eighteen inches is the maximum size," but I have handled a specimen-one of a small school of the same size-measuring more than 27 inches. This specimen was captured in Rose Bay, Port Jackson, and is now later.

* This must not be confused with the Spanish Mackerels mentioned 
in the collection of the New South Wales Department of Fisheries.

The Horse-Mackerel abounds in such widely-separated localities as New Zealand, Japan, San Francisco, Chile and Patagonia.

In America, where it is called the "California Bonito, large numbers are salted and dried for human consumption, and there appears to be no reason why the same should not be done here. During the summer and the autumn, large numbers are captured by trolling, among the Santa Barbara Islands, off the coast of California.

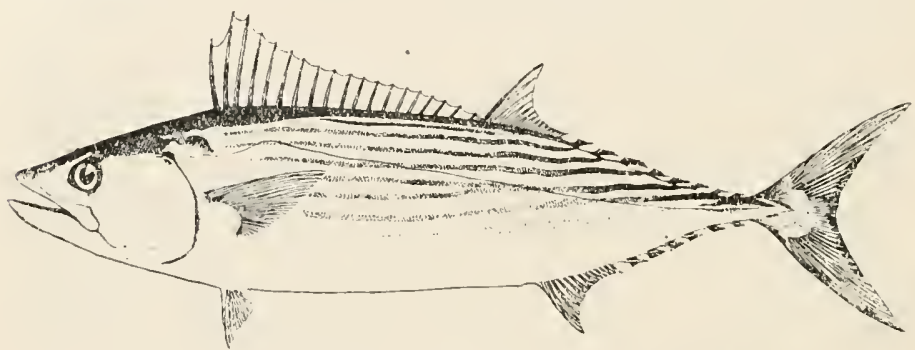

Fig. 59.-Horse-Mackeret, (Sarla chilensis).

When freshly taken from the water the Horse Macker is a strikingly handsome fish. The colour of the back is a dark metallic blue; the sides being dusky and the belly silvery. There are a number of dark stripes running obliquely upward and backward from the pectoral region to the upper edge of the tail; these stripes being variable both in number and direction.

The Bonito: This fish is somewhat larger than the last-mentioned, and-as far as the New South Wales coast, at least, is concerned-occurs in shoals at more frequent intervals. As it is considered by our fishermen to be of little value, it is very rarely to be seen in our fish markets. However, as it is a game-fish of some worth, advantage is usually taken of its presence in our harbours by numbers of amateur line-fishermen, who derive a considerable amount of sport from its capture.

Having a very wide geographical distribution-as is the case with most scombroid fishes-it is known from many 
parts and under many names. In America, where it is found on both the Atlantic and Pacific coasts, it is known as "Oceanic Bonito"; the first portion of its name of course being in reference to its free pelagic existence. It occurs also upon the shores of Great Britain, Japan, India, China and many other places.

The back of the Bonito is bluish, the belly being silvery with four brownish stripes on each side parallel with the lower curve of the body.

The Albacore is still more pelagic in its nature than any of the others so far mentioned, roaming the wide oceans within tropical and sub-tropical zones, and seldom entering coastal inlets. It is closely allied to the large Tunnies, from which it differs chiefly in having the pectoral fin very long ancl shaped like a sabre; in the adult the length of this fin being about two-fifths of that of the body.

As a food-fish, this species is of little value, its flesh being coarse and oily.

It attains a length of over four feet, one of that size having been captured in I903, at Port Macquarie, on the coast of New South Wales.

It appears to be very rare in Australian waters.

Sailing, ships when cruising in the Pacific Ocean, have been known to be attended by myriads of this species for many successive months.

Fn regard to the name of this fish it may be mentioned that Jordan and Evermann state that "Albacore is from Albacora, a Portuguese name, said to be from the Arabic al a, and bacora, little pig. It should not be spelled Albicore as it is not connected with Albus, white."

The Spanish Mackerels: I have here adopted the title. used by the American Ichthyologists just quoted, for fishes of the genus Scomberomorus. We have two kinds on the coast of New South Wales, both of which attain to very large proportions and are very widely distributed. In a general way they may be distinguished from one another. by the fact that in S. guttatus, there are a number of large ovate spots of a dark colour, distributed over a great part 
of the body; while in S. commersonii there are indistinct vertical bars and no spots.

At times immense shoals of these fishes visit the shores of New South Wales; but no notice is taken of them in a commercial way at present, though there appears to be every possibility of a lucrative fishery being established on our coast some day.

A few years ago, a large shoal of Spanish Mackerel "ran ashore" on a beach a little to the south of Wollongong, N.S.W., a mound of them about 2 miles in length being naturally formed from their numbers. Doubtless these had been pursued by either Dolphins ("Porpoises") or Sharks.

One of the Spanish Mackerels in America, closely allied to our two, is S. maculatus. This fish is now one of the most highly-esteemed of all American fishes, always commanding a high price. The catch in 1897 amounted to I, 183,456 pounds, worth nearly $£$ I4,000. May the time be not far distant when we will have catches of our oceanic fishes approximating to this amount!

\section{THE BARRACOUTA FAMILY.}

(Family: Trichiuride.)

THIs family is an important one from an economic point of view, because it includes in its number, the well-known Barracouta (Thyrsites atun). Altogether, in this family there are about 25 species, widely distributed and of a pelagic nature; some of them being found in the great ocean depths, while others are surface-fishes, living in the vicinity of coastlines. In all of these, the body is elongate and compressed; sometimes being even band-like. Their jaws are usually armed with strong teeth. In addition to the Barracouta, which, undoubtedly, must have first place, amongst the more striking forms occurring on the Australian coast, might be mentioned, the Australian Hairtail (Trichinrus 
coxii), and the Scabbard-Fish or Frost-Fish (Lepidopus candatus).

The Barracouta is a highly voracious fish, attaining a large size and distributed over many waters. It is a very valuable food-fish, immense numbers being captured and preserved by either pickling or smoking, ann ally, for table purposes. At the same time, though, when properly prepared, it is undoubtedly of good flavour, it can hardly be placed amongst our first-class table fishes. The species is commonly found in the waters of Chile, the Cape of Good Hope, New Zealand, Tasmania, South Australia, (?) Western Australia, Victoria and New South Wales. A great fishery for the Barracouta exists in the vicinity of Bass Strait, large numbers being captured and forwarded to Melbourne and Sydney for disposal, in addition to those which are disposed of in Tasmania. Their capture is effecter

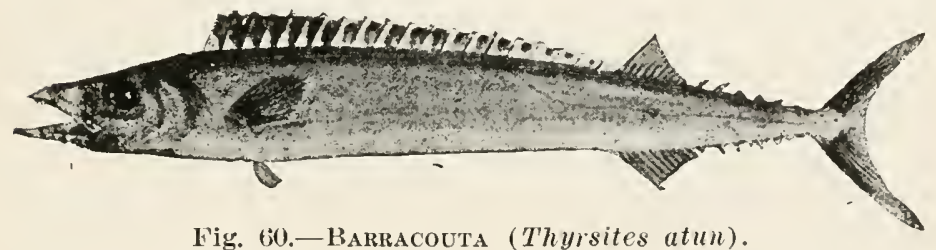

by means of hook and line; and in this no difficulty is experienced, as the Barracouta is neither particular as to the kind of bait used nor slow about taking it. Any bright moving object is sufficient to attract the fish, a piece of red flannel fastened to the hook being a first-class bait. When the Barracouta are at all "thick" large hauls are often made within a very short time. Recently, in one day and from a small steam-launch off Derwent Lighthouse, Tasmania, the great haul of over 2000 of this species is said to have been made. In South Africa also, where the fish is known as "Snoek," a great fishery exists.

The Barracouta is quite common along the most southern portion of the coastline of New South WVales; and, during the last few years-in the winter-time-it has made its appearance in fairly large shoals in Port Jackson, and as 
high up as Port Stephens; while it has once been observed in the vicinity of Moreton Bay, in Queensland. This last. record however must be taken as denoting a very exceptional occurrence indeed.

As this species does not "keep" well in a fresh state (and because of the flesh being naturally rather soft), it is not often sold in that condition. However, it takes the smoke well, consequently "Smoked Barracouta" is the usual form in which it is familiar to the majority of the public.

'The teeth are very sharp and formidable-looking; and I may mention, that there are several finlets-as in the Mackerels-following both the second-dorsal and anal fins.

It attains commonly a length of about 4 feet.

The Australian Hairtail is not often seen by the majority of, even, the fisher-folk. In shape it differs considerably from the Barracouta, there being no caudal fin as in the latter; the body being ribbon-like and tapering to a fine point. Neither are there any of the little finlets, as there is one single dorsal fin extending the whole length of the back. There are several long fang-like teeth in each jaw.

It usually attains a length of about 4 feet.

The Scabbard-Fish is very similar in the shape of the body to the Hairtail, but differs in that there is a small but well-developed caudal fin. It is a very widespread species: in addition to occurring in Tasmania and on parts of the south-eastern coast of Australia, being found in New Zealand, South Africa and the European Seas. In New Zealand, where it is always known as "Frost-Fish," it is greatly esteemed as a food-fish.

This fish is considered to be usually an inhabitant of deep ocean waters.

It grows to a length of about 6 feet.

The fish known in Cuba as the "Escholar" and in the South Sea Islands as "Palu" (Ruvettus pretiosus) is also a member of this family. I mention this as many Australians must have seen the so-called "palu-hooks" and wondered what species they were intended to catch. 


\section{Chapter IX.}

Swordfishes or Spearfishes The I.uvarus Fish-Dolphin-FishesThe Pomfrets-The John Dory Family-The Flat-Fishes-The Goby Family.

\section{SWORDFISHES OR SPEARFISHES.}

(Family: Histiophorider.)

THE Swordfishes, or, more properly, the Spearfishes, are large oceanic fishes, occurring in all tropical and temperate seas. They are endowed with extraordinary strength and velocity, and most of the species are but rarely captured. Next to those powerful and masterful cetaceans, the Killers (Orca gladiator), I think they may be regarded as the Lords of the Ocean; and they are the largest among all Teleosteans: attaining to lengths of from I 2 to $\mathrm{I} 5$ feet. The "swords" or "spears" differ in length in the various species; in the typical Histiophorils gladius reaching a length of at least 4 feet.

The Spearfishes are much respected by fisher-folk, because of the formidable weapon that they carry about, always ready for immediate action. Not only are they always ready, but apparently they are always looking, for a fight : their pugnacity being well-known and having passed into a by-word. Many are the tales of ships being attacked by these mischievous "demons-of-the-deep," a large number of them being undoubtedly founded on fact. In some cases timbers of more than a foot in thickness have been pierced, in the majority of instances the spear or sword having been broken off into the hole formed by it.

One does not need to go abroad for these occurrences. as, within the last few years, there have been several cases chronicled as having happened within our own waters. At first sight it appears, perhaps, marvellous, that these fishes are able to penetrate the sides of ships; but when the size, 
solidity and strength of the weapon, the weight of the body behind it, and the enormous power and great speed of this fish, are considered, the thing appears fairly simple.

On the east coast of the United States of America a fishery for the capture of these fishes exists, and large numbers are caught annually. There is also a small fishery in the Straits of Messina in the Mediterranean Sea. "The apparatus ordinarily employed for the capture of the Swordfish is simple in the extreme. It is a harpoon with a detachable head. When the fish is struck, the head of the harpoon remains in the body of the fish, and carries with it a light rope, which is either made fast or held by a man

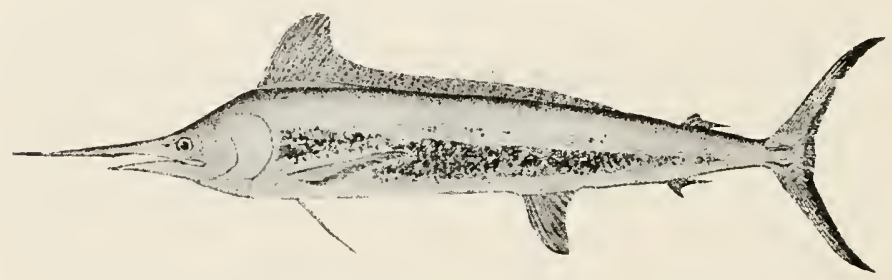

Fig. 61.-SPEARFISH OR SWORDFISH (Tetrapturus indicus).

in a small boat, or is attached to some kind of a buoy, which is towed through the water by the struggling fish and which marks its whereabouts after death."-(Goode.)

The "spear" is formed by a prolongation of the upper jaw. In very young specimens both jaws are slightly produced and the eyes are of a great size, and as the little fish grows, its eyes become relatively smaller, while the upper-jaw grows longer and longer.

Amongst the various species of Spearfishes, is one known as Tetrapturus indicus. This species is widely-distributed and amongst other localities is known to occur occasionally on the coast of Australia. In this fish, the spear is considerably shorter than it is in the typical species, before-referred-to, though it is exceedingly stout and powerful. During I905 a fine example of this Spearfish was captured in Port Jackson, by a fisherman named Skinner, re- 
siding at Manly (Port Jackson).* The "spear"-measuring more than 2 feet-and also a photograph of this specimen are now in the collection of the New South Wales Department of Fisheries. The whole fish measured about 12 feet. Some years ago (I880) a specimen of the same species was captured about 6 miles south of Wollongong, N.S.W., by a party out for Snapper. They had found that many of the fishes hooked, were taken off the lines: and soon after a large Spearfish in pursuit of a Snapper, became entangled in the anchor-line, which had become twisted round its snout; thereby enabling one of the party to successfully harpoon it. The animal towed the boat for several miles and then, becoming exhausted, was towed ashore. Shortly after being harjooned, it disgorged a number of Snapper; this being regarded as evidence that it had been the culprit. During the fight it leaped scveral feet out of the water. This example measured about I4 feet.

\section{THE LUVARUS FISH.}

(Family: Invaridce.)

THE sole representative of this family-Luvarus imperialisis one of those fishes which are rarely seen and about the habits of which, consequently, very little is known. Boulenger points out that: "The excessive length of the intestines and the feeble dentition point to its feeding partly on vegetable matter, partly on minute animals; the circumstances under which certain specimens were captured tend to indicate that they follow up streams of pelagic life such as engage the attention of the Basking Shark, of similar distribution." Pelagic in nature, it is known to occur in the Mediterranean Sea and the Atlantic and Pacific Oceans,

* Mr. Skinner informs me that about 3 months after the capture of this fish another one of about the same size was seen cruising about in the same locality. 
where it attains a length of about 6 feet. It is occasionally captured on the British coasts.

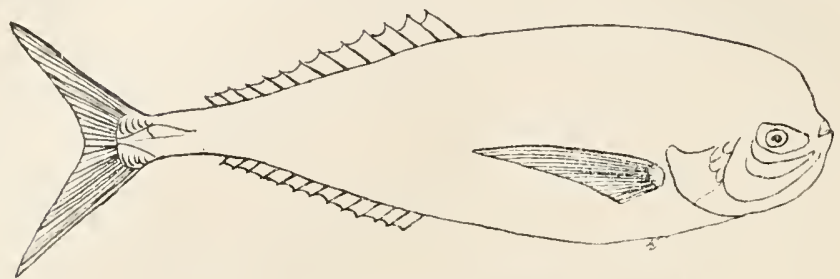

Nig. (i2.-Luranos fish (Lucarus imperialis).

Only once has this interesting fish been known to have been captured on the Australian coast: the locality being Bermagui, N.S.W. This specimen measured about 6 feet 2 inches in length, the girth being 4 feet 8 inches and the spread of the tail 2 feet 3 inches. The weight was between 2 and 3 hundredweight. The colour was a silvery salmon-pink such as one sees in the Nannygai.

It is supposed that this Luvarus had become stranded while in pursuit of food; as, when it was discovered, it was surrounded by a large quantity of the small crustaceans known as "Whale-Feed."

\section{DOLPHIN-FISHES.}

(Family: Coryphenida.)

AT the outset, I would like to make it quite clear, that these fishes are not to be confounded with the cetaceans known as Dolphins, which are warm-blooded mammals like the Whale. I feel it necessary to mention this, as I find there is considerable confusion at times on the point.

The Dolphin-Fishes are large, pelagic fishes of a carnivorous nature; very widely distributed in various oceans They are very remarkable-looking, with their high "foreheads," their elongate, narrow bodies and strong forked 

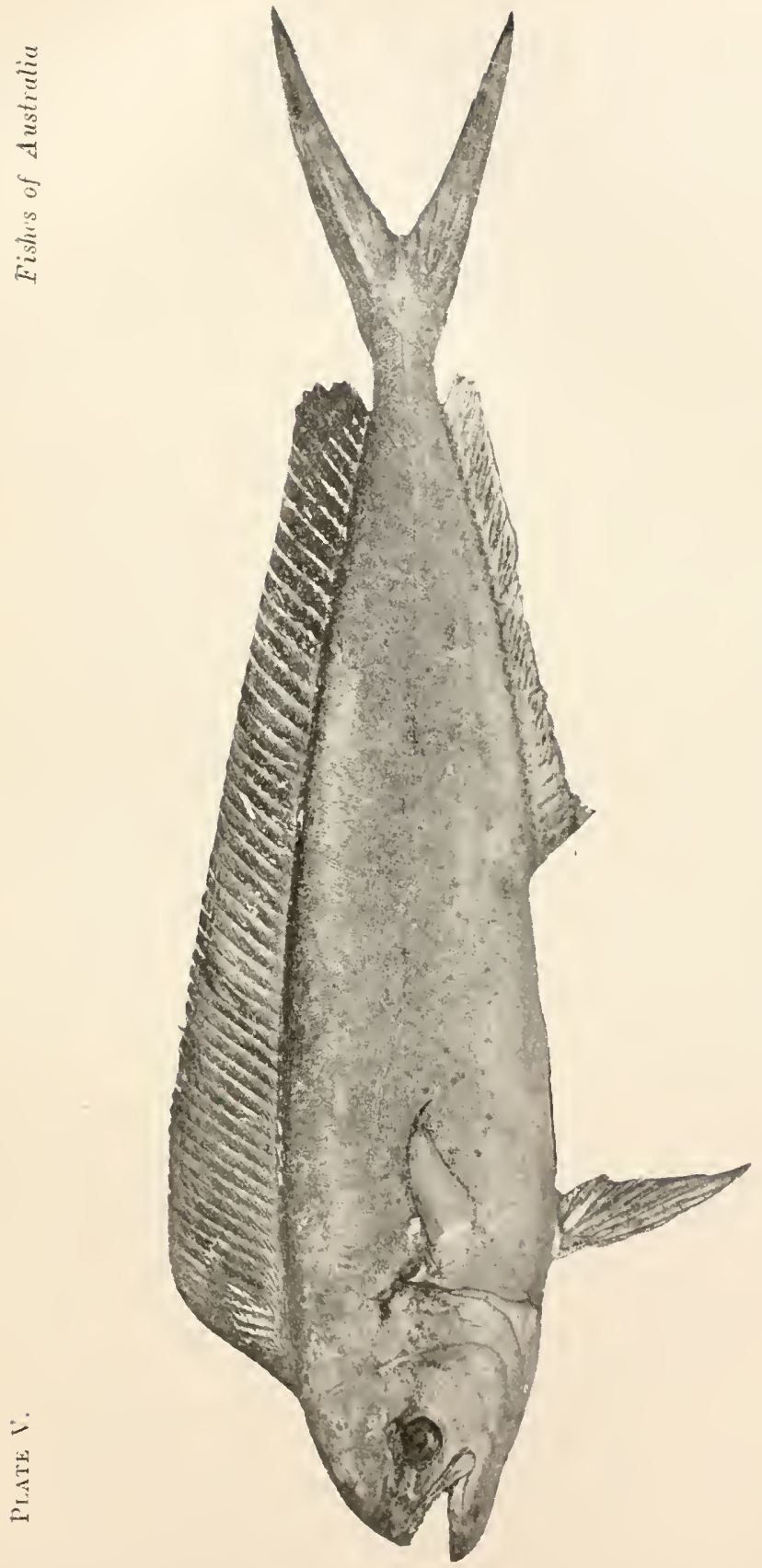

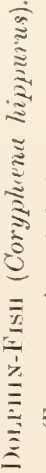



tails. A single dorsal fin extends from the back of the very deep head almost to the caudal fin. As the fishes increase in age, this dorsal fin becomes higher in its anterior part. They are most powerful swimmers, congregating in sloals and pursuing the Flying-fishes unceasingly. Whenever possible, they are eagerly captured by sailors, who consider the flesh to be of very good flavour. Günther states that the form of the body and especially of the head, changes considerably with age. Very young specimens-from one to six inches in length (which are abundant in the open sea)-have the body cylindrical, with the head as broad as it is high. As the fish grows, the body becomes more an:l more compressed. Of the two "good" species cxisting, the most important is the Common Dolphin-Fish (Coryphana hippurus), which grows to a length of 6 feet. This species has been captured on a number of occasions on the coast of New South Wales. Jordan and Evermann, writing of this family, state that it is the custom of seafaring men before eating them, to test the flesh by putting a piece of silver into the vesse! in which they have been cuoked; it being a common belief, that if the flesh is poisonous the silver will turn black.

Narratives of ocean voyages abound in descriptions of the beautiful colours of these "dolphins" and the brilliant changes of hue exhibited by the fishes when they are dying. I have never seen any of these while alive but have handled them soon after death; and even then the colours were magnificent. Günther gives the following as the colours:"Silvery-blue above, with markings of a deeper azure, and reflections of pure gold; the lower parts being lemon-yellow, marked with pale-blue. The pectoral fins are partly leadcolour, partly yellow; the anal is yellow, the iris of the eye golden." This description of course, however good, can give but a feeble idea of the magnificence of this fish. 


\section{THE POMFRETS.}

\section{(Family: Bramider.)}

THE fishes of this family usually inhabit the open sea and some of them are found in the great ocean depths. About 12 species are known. The fishes of one of the genera, known as Pteraclis, are very remarliable for the enormous sail-like dorsal and anal fins. Perhaps the best-known species of this family is the Pomfret (Brana raii), also known as "Ray's Bream." This is a fish of wide distribution and of considerable value in portions of its habitat as

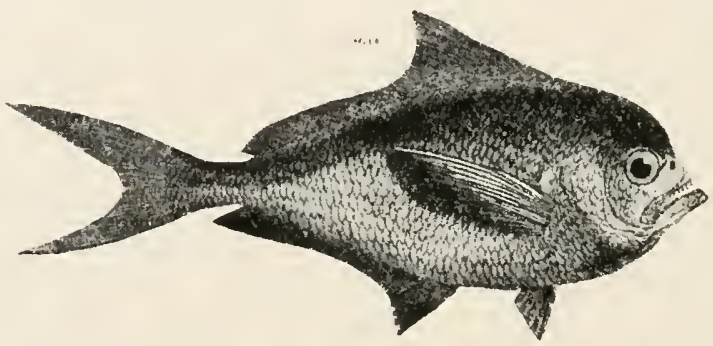

Fig. 63.- Ponfret (Brama raii).

a food-fish. It has been obtained on the coast of New South Wales, but is here exceedingly rare. In the Mediterranean Sea it is common, while, in American waters, it is stated by Jordan and Evermann to be rare on the Atlantic coast, but not uncommon on the coast of California and north to Puget Sound "where it is regarded as an excellent foodfish." The Pomfret-that is the American name-is a deep-bodied fish, growing to a length of from 2 to 4 feet.

The colour is described as a sooty-gray, with some "soiled silvery on the snout."

\section{THE JOHN DORY FAMILY.}

(Family: Zeida.)

THE "Dories" are widely-distributed marine fishes, inhabiting the temperate zones of both the Northern and Sonthern 
Hemispheres. Taking a cursory glance at them, the most striking features are, the high, narrow body and the very grotesque-looking face. The latter is particularly pronouncer in the typical "John Dories" of the genus Zeus, in which also will be at once noticed, the large spot in the centre, on each side of the body-of which more anon.

According to Boulenger, 12 species of this family are known from the Atlantic and Pacific Oceans.

The common European species of John Dory (Zeus fabcr) is so well-known in literature-being a familiar object even in children's books-that little description of it is necessary; and those who are familiar with the appearance of that fish, could at once-knowing the localityidentify the very closely allied Australian John Dory (Zeus australis).* This fish, which is common in fairlydeep water off the coasts of New South Wales, Victoria and Tasmania, usually attains a length of about $\mathrm{I} 8$ inches. It is an excellent fish for table purposes, though seldom brought in to the markets-at least in New South Wales-there being no special fishery in existence for this fine fish. In the special capture of this species, the "trawling-net" would be a necessary adjunct.

A series of bony plates, runs along the bases of both the dorsal and anal fins; there being another series along the abdomen.

In regard to the large dark spot on each side, before referred to, much has been written. "'The fishermen of Roman Catholic countries hold this fish in special respect, as they recognise in a black round spot on its side, the mark left by the thumb of St. Peter when he took the piece of money from its mouth."-(Günther.)

"The Dory, or Doree, contends with the Haddock, for the honour of bearing the marks of St. Peter's fingers, each being supposed to have been the fish out of whose mouth the Apostle took the tribute money; leaving on its sides, in proof of the identity, the marks of his finger and thumb.

* Some are inclinerl to believe that the Australian John Dory is merely a "local variety" of the European form (Zeus faber). I have not yet had an opportunity of comparing the two. 
Another origin for the spots on the sides of the Dory has also been assigned. St. Christopher, in wading througl an arm of the sea, bearing the Saviour, whence his name of Christophorus, is reported to have caught a Dory, and to have left those impressions on its sides, to be transmitted to ali posterity as an eternal memorial of the fact." (Yarrell.)

Another Australian member of this family that should be mentioned, is the Silver Dory (Cyttus australis). This is a smaller species than the preceding and is found in the waters of New South Wales, Victoria, Tasmania and South Australia. In New South Wales it is of rare occurrence but in the colder waters of the South it is more common-occurring in schools.

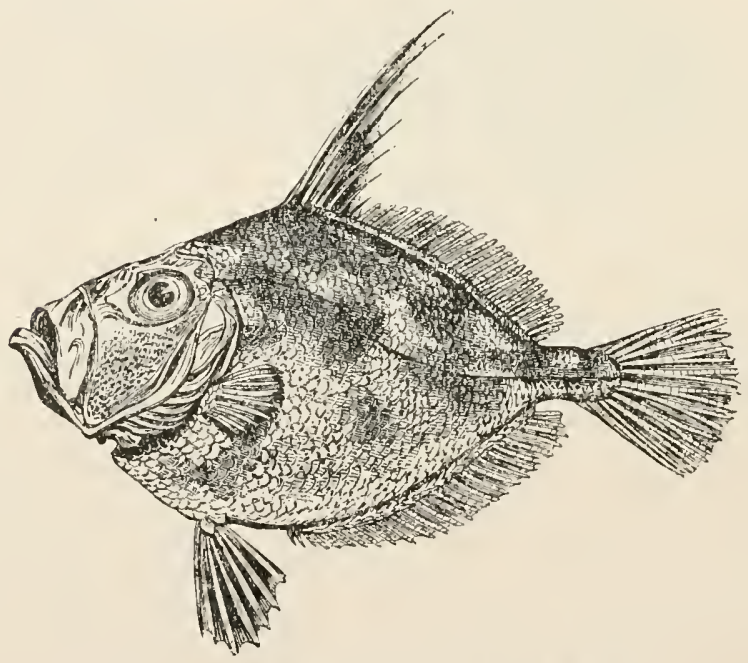

Fig. lit.-DILver Dori (cyuttus australis).

As might be judged by the common name, this species is of a beautiful uniform silvery appearance (though more roseate when first captured). The body is covered with very small scales and there are no bony plates on the body. The first dorsal fin is very short, high and pointed. The mouth is telescopic, though not to such a degree as in that of the John Dory.

In Tasmania this is known as "Bastard Dory." 


\section{THE FLAT-FISHES.}

(Family: Pleuronectide.)

LIKE the family of the Gobies, this family of fishes enbraces a huge number of different forms; but, unlike the Gobies, they include a very large number of species of the greatest economic importance: and most of them are used by Man in different parts of the world as food. As will be apparent, perhaps, from their general shape, they are all bottom-haunting fishes. The smallest among them average but a few inches in length, but the majority grow to a fairly-large size: while a few of them are very large indeed. The largest of all is the Halibut (Hippoglossus zulgaris) of European seas, which attains to the comparatively enormous length of ro feet or more, with a correspondingly huge weight; examples of 6 to 7 feet in length being common.

These fishes are termed "Flat-Fishes" on account of the strongly-compressed, high and flat body, which, in a varying extent, is common to all of the species. It must be at once remembered that they lie on their sides and that the dark or coloured part which is uppermost, is one of the sides and not the back. It is well to remember this, otherwise a great deal of confusion will arise. That side which rests against the bottom is normally whitish and without any spots of colour; while the upper side is variously coloured, according to the habitat and the environment of the particular species; some being striped or spotted, while others are mottled or of uniform colour. Not uncommonly however in certain species, both sides are coloured alike; the lower surface assuming the tints of th: upper. I have known this to occur rarely in one of our own common Flounders.

In adult Flat-Fishes, both eyes-it will be noticedare on the same side of the head; in some being very close together and far removed from the upper border of the head, while in others they are far apart; the one belonging to the underside apparently having just managed to make its way round to the desired side and no more. In their 
early life these fishes pass through the same stages as do most others which-like these-are hatched from a pelagic egg; and for some time (the period being longer or shorter according to the species) they are quite symmetrical, the eyes being in their natural positions, one on each side of the head; but, after a while, the eye on that side which is destined to be the underpart, begins to work round to the other side and toward the light, as the fish gradually takes to living on the one side at the bottom. In some species, it is believed-with good reason-that the eye actually works through the head. That side which rests against the bottom and which becomes in early life eyeless, is called the "blind" side. In some species this is the left side, while in others it is the right.

Amongst the numerous Australian Flat-Fishes may be mentioned the Large-toothed Flounder (Paralichthys arsius), the Small-toothed Flounder (Paralichthys novecambrice), the Southern Flounder (Rhombosolea monopus), the Queensland Halibut (Psettodes erumei), the Black Sole (Synapturanigra), and the Lemon Sole or Tongue-Fish (Symphurus unicolor). For the purposes of this little volume, a very few words in regard to each must suffice.

The Large-toothed Flounder is one of the commonest of the Flounders of New South Wales and Queensland. It has an immense geographical distribution; in addition to the localities mentioned being found in the Seas of the Malay Archipelago, China, Japan, India, the East Coast of Africa, as well as in the Red Sea. Being, as will be seen, a tropical species, it is more abundant in the northern parts of New South Wales, becoming uncommon as we approach the southern extremity.

It attains a length of about $I_{5}$ inches and is a firstclass table-fish.

In colour, it is yellowish-brown with darker mottlings, there being, usually, several white-edged spots along the centre of the body.

Apart from considerations of colour, this species may be distinguished from the Small-toothed Flounder by (I) 
the presence of several comparatively-large canine teeth near the front of jaw (while in the latter the teeth are fairly-uniform in each jaw, being but slightly enlarged at the front of the upper jaw), also, (2) the slightly increased number of dorsal and anal rays, as compared with the small-toothed Flounder, and the presence upon the lower jaw of a pronounced knob, with-usually-a slight notch beside it; the projection when occurring at all in the other kind, being not at all prominent.

The Small-toothed Flounder, often known as the "Spotted Flounder," has not, as far as we at present know, a great distribution; being only known from the coast of New South Wales, on parts of which it is very abundant. It usually frequents sandy bottoms, from a few fathoms in depth up to the shallowest water, being at times quite abundant upon the shallow grass-covered flats at low water. Here they lie apparently without fear, relying upon their protective resemblance to their surroundings to enable them to escape observation. Thus a person may often take a boat and glide slowly over the flats where these fishes are lying, capturing them with a spear or even-in very shallow water -by leaning over and impaling them on a knife. The greatest difficulty, however, is not to catch them, but, first to distinguish your prey from its surroundings.

This species grows to a length of over i6 inches, though those brought to market would probably average not more than Io inches.

In colour this fish is of a rich brown or greyish on the upper surface, with numerous small, round, white spots scattered about it. There are some dark spots along the lateral line (the middle ones being the most conspicuous), each spot being closely dotted with yellow or white. In addition there are fine, dark marblings over the whole of the side and the fins.

Both this and the preceding species are carnivorous fishes subsicting upon such organisms as are usually foun.1 in sandy localities-small fishes, crustaceans and mollusks. 


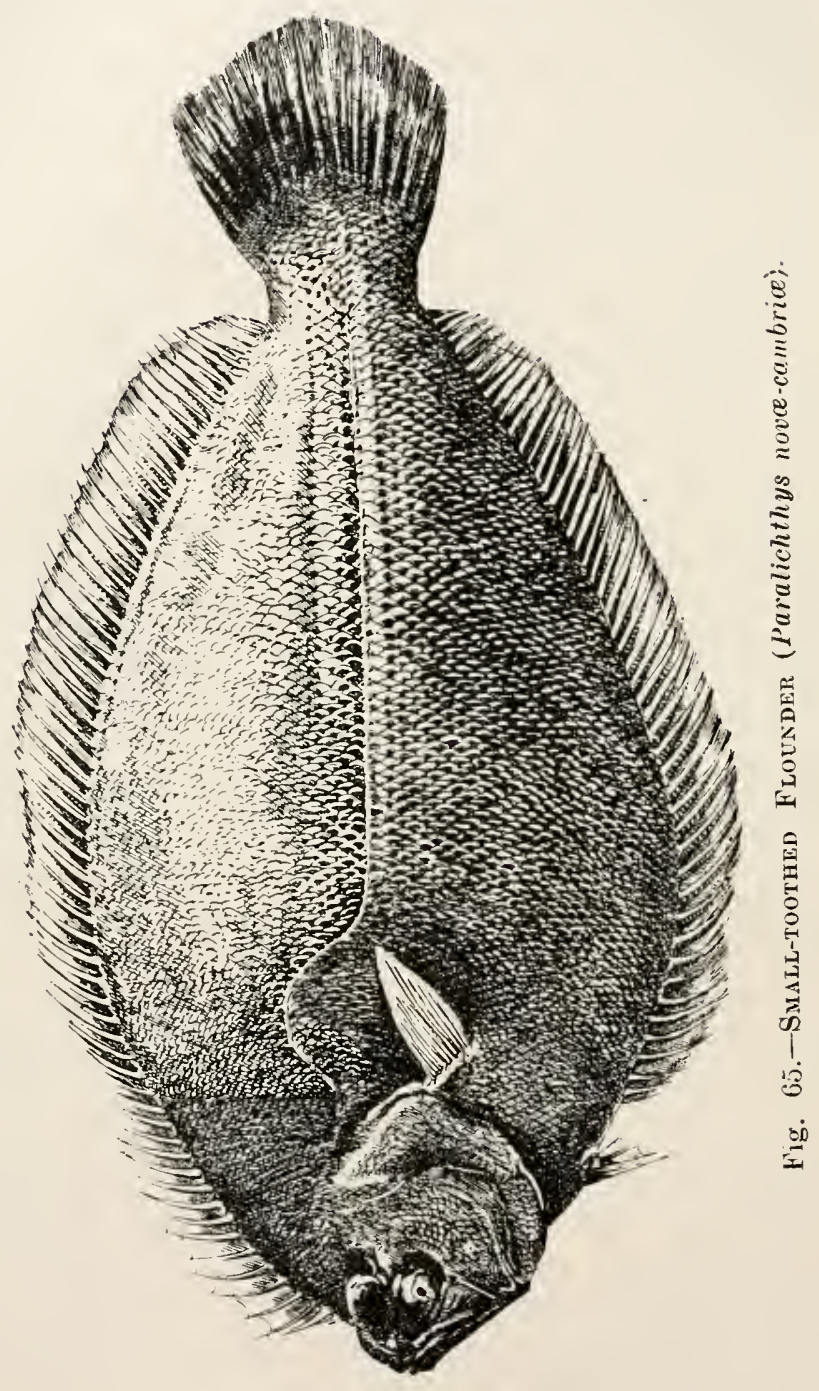


The Southern Flounder: This fish occurs in the waters of Victoria and Tasmania: being found most commonly, however, in New Zealand. It is the species which is retailed in Sydney fish-shops as "New Zealand Flounder" after having been exported from New Zealand in a frozen or smoked condition. It attains to a somewhat larger size than either of the preceding.

In New Zealand, where this fish is often known under the Maori name of "Patiki," it is very common in the shallow bays and tidal estuaries on every part of the coast, and is everywhere esteemed as food. The Maoris used to capture them on the shallow mud-flats by means of a long slender spear; choosing the night-time, and each carrying a lighted torch or a pan of flaming kauri gum on the shoulder; thus attracting the Patiki and enabling them to be observed and speared as they glided over the bottom.

The Queensland Halibut: This is a highly-interesting member of the Flat-Fish family, it having retained a more symmetrical shape than any of the other species; consequently, its eyes are as often found on the right side as on the left. Its body is more elongate, not having such a great relative depth as is usual in these fishes and it is said to frequently swim in a vertical position.

It has a fairly wide distribution in the Indian Ocean, and also occurs on the coast of Queensland, growing to a length of nearly 2 feet.

It has a most ferocious aspect, the mouth being very wide, and each jaw being armed with two series of long, slender, curved teeth; the front teeth of the inner series of the lower jaw being the longest. These long teeth (which are widely-separated from one another) are received into a kind of groove or pit in the upper jaw, immediately in front of the vomer.

The Black Sole is, no doubt, a very familiar fish to most of my readers. Owing to its rather unique shape as compared with our other fishes, it is not readily forgotten when once seen. The long dorsal and anal fins are joined, at their ends, to the small caudal fin, this giving the fish the appearance of being without any tail fin at all, and making its general outline a fairly-regular oval. 
The Black Sole is very abundant along the coast of New South Wales, and the southernmost portion of that of Queensland; probably occurring also along the northern parts of Victoria. It frequents the mud-flats and muddy bottoms; being found commonly in water from a few inches in depth down to 3 or 4 fathoms. In the vicinity of Sydney the localities where they are most plentiful are George's River, Parramatta River (the head of Port Jackson) and Middle Harbour (Port Jackson). During the summer months, when these fishes are spawning, large numbers of mature specimens are to be found on the sandy flats in Botany Bay, at the entrances to George's River and Cook's River. Most of the Soles captured at this time and at this locality, have assumed-consequent upon their altered surroundings-quite a light sandy-colour. During the last few years a rich harvest of large marketable fishes has been reaped amongst these spawners, by fishermen using a long shallow kind of trammel-net. Unfortunately however, most of the fishes so caught are full-roed; thus a large contribution of eggs to the local supply is forever lost. (In regard to the ripe eggs; they are comparatively large; not "very small" as stated by Ogilby.)

The normal colours of the Black Sole are as follows: The blind side is whitish or yellowish-white. The upper side is of a rich olive-brown, mottled over with large, irregular, darker blotches. There is a certain amount of variation, according to the situation.

This species is fairly common in the fish markets of Sydney, but is not so abundantly represented as it would be if a special fishery existed for it. Nearly all of the Black Soles netted (with the exception of those just mentioned as being captured in Botany Bay) are caught amongst other fishes. They always bring a higher price and in certain quarters are highly esteemed.

The Black Sole grows to a length of 14 inches, with it weight of about 2 pounds.

The Tongue-Fish is a native of the coasts of New South Wales and Queensland, being also found at Lord Howe Island. From its very elongate form it has earned the common-name here used. The outline of the hody is 

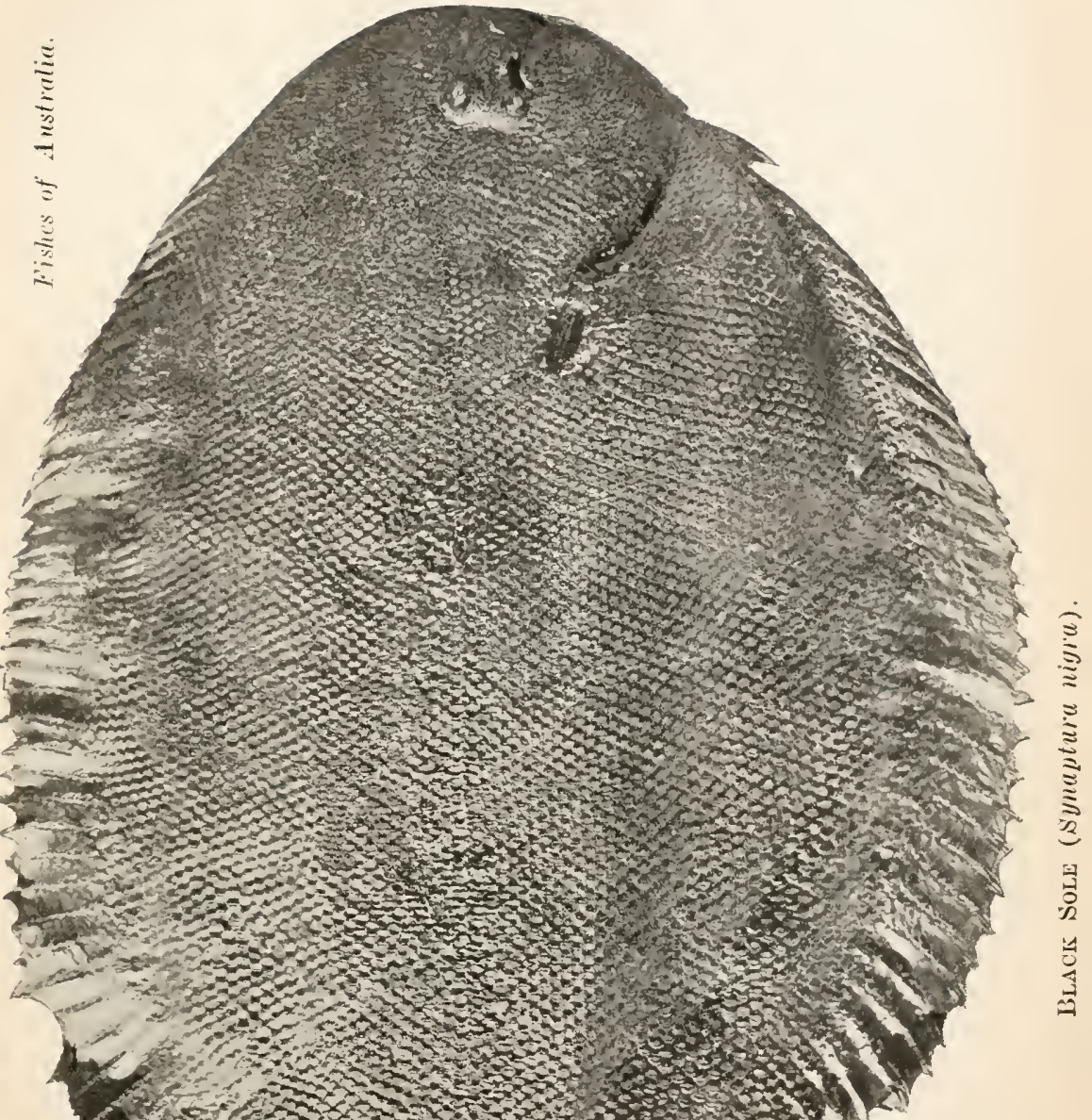

that of a very long oval, pointed at the tail end. The upper part of the snout is produced backwards into a long hookshaped flap, known as the "rostral hook."

In colour, the upper side of this fish is a pale yellowishbrown, with numerous round spots of a creamy tint.

Though there is no reason to doubt that this species is fairly common along our open sandy sea-beaches (whereon it loves to dwell), it is seldom captured.

It grows to a length of nearly I 3 inches.

Amongst other species of our Flat-Fishes might be mentioned the Long-snouted Flounder (Ammotretis rostrata), the Narrow-banded Sole (Solea macleayana), the Crested Flounder (Lophonectes gallus) and the Peacock Sole (Achirus pavoninus).

\section{THE GOBY FAMILY.}

(Family: Gobiida.)

THIS is quite an enormous family of fishes, embracing as it does about 600 different species. They are chiefly of small size, including amongst their number, the tiniest fish (and at the same time the smallest vertebrated aninal) that exists. This little Goby is a native of Luzon, in the Philippine Islands, where it is used as food, and where it attains the wonderful size of just about half an inch. However all the Gobies are not small, as there is a species of Eleotris in the rivers of Siam, Borneo and Sumatra, which grows to the majestic size - for a Goby-of nearly 3 feet.

Gobies are distributed over all the oceans of the world. with the exception of those lying within the cold regions of the Arctic and Antarctic Circles. Those which are marine, are usually found upon rocky coasts; even, in some instances, in water which is subject to constant and violent agitations. To enable them to withstand this agitation of the water, as well as the action of sea-currents-local or otherwise-many of these fishes have the two ventral fins 
placed very close together and converted into a kind of cupshaped sucker, by the aid of which they are able to place themselves in all sorts of apparently-"impossible" positions.

Amongst the many Australian species, the following might be mentioned as being either prominent or striking:The Bridled Goby (Gobius bifrcnatus), the Striped Gudgeon (Krefftius australis), the Carp-Gudgeon (Carassiops compressus), the Mud-Skipper (Periophthalmus australis) and the Eel-like Goby (Gobioides purpurascens).

The Bridled Goby: This pretty little Goby is an inhabitant of the shores of New South Wales and Victoria. It loves to dwell upon the mud-flats such as one finds in the higher parts of Port Jackson (where-by the way-it is known to the fishermen as "Mud-Gudgeon") and other similar localities. Of the comparatively-few species of fishes captured in the process of hauling with the "prawn-net" within these regions it is perhaps one of the most common.

It is a very elongate fish: the head being somewhat round and tad-pole like, and having pretty bluish stripes on each side of the face. The body becomes gradually narrower as it approaches the tail, which is highly compressed. The tail-fin is comparatively large and fan-like, being in the male considerably produced. Here we have one of those instances-rather uncommon amongst fishesin which it is possible to distinguish the sex of the fish by external characters.

The Bridled Goby grows to a length of from 5 to 6 inches--exclusive of caudal filaments.

The Gudgeons: Amongst the smaller species of our Australian fresh-water fishes, perhaps the most abundant are those usually styled "Gudgeons." The simple and convenient term "Gudgeon" is made to apply, to the whole of the known species-as well as, I am sorry to add, several others of a totally different character, which have no right to the name whatever. Excepting, perhaps, regions of great altitude, these Gudgeons are plentifully distributed in the rivers, creeks and pools throughout the length and breadth of Australia. They are all small fishes, the largest growing to a length of 6 or 7 inches. People often mistake them for the young of larger species, for instance, adults of the 
Purple-striped Gudgeon (Krefftius adspersus) of the Western River-system of New South Wales, being often taken to be the young of the Murray Cod.

In New South Wales, one of the commonest kinds is the Striped Gudgeon of which the natural habitat is the Eastern watershed. It is rather prettily striped with dark longitudinal bars and the dorsal and anal fins are very beantifully variegated: the latter being a feature common to most of the Gudgeons, being more particularly apparent in the males and during the spawning season.

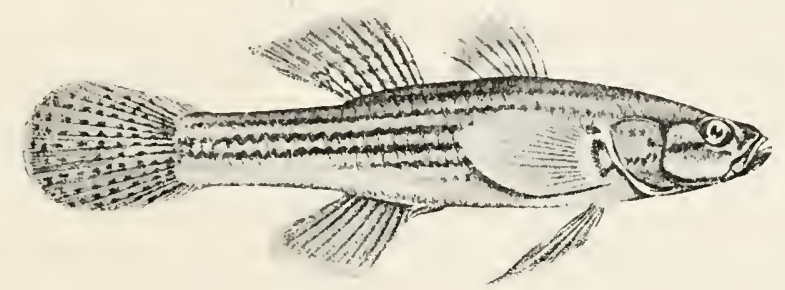

Fig. 66.-STriped Gudgeon (Krefftius australis).

In the creeks and waterholes around Sydney, this little fish-which attains a length of about 5 inches-is known under quite a variety of names by different "schools" of boys; one very inappropriate name being that of "Cod."

Anyone having a little knowledge of fish life and at the same time possessed of some insight into the conditions which govern our Australian land water-system, might suppose that the Gudgeons-which live in all sorts of out-ofthe-way waterholes, creeks and lagoons subject to a periodical drying-up-would show great tenacity of life and adaptability to conditions which would be absolutely fatal to many aquatic organisms; and this they certainly do in a very marked degree. When the pond or creek in which any of these are situated, begins to show signs of drying up, the Gudgeons burrow into the mud, and so long as the mud keeps a little damp, they are able to remain alive for a very long time. Recently, I had an experience of the tenacity of life of the Purple-striped Gudgeon before referred to. A parcel of fish specimens had been brought to me. for identification of species, from Wagga Wagga, 
on the Murrumbidgee River, N.S.W. The fishes included one Macquarie's Perch about I foot long. two or three Carp, and two examples of Purple-striped Gudgeon, a little over 3 inches long. They were all wrapped up in several thicknesses of newspaper, into which they had been placed early in the previous afternoon at Wagga Wagga. They had then been brought down in the train-a journey of 314 miles; no special care being taken of them-that is, no more care than a parcel of dead fish would merit. I opened the parcel about 12 o'clock the next day (nearly 24 hours after) and as the fins and skins were rather dry, threw all of the fishes into a basin of water to "soak them out" prior'to preserving them in formalin. About ro minutes afterwards, upon going to examine them, my astonishment can be better imagined than described, when I found the two Gudgeons swimming round and round, one of them quite serenely and the other just a little "lamely," as though it had been bruised a little on one side. I kept the first one alive in a jar of water for some time after and he remained perfectly healthy.

The Carp-Gudgeon: This interesting and beautiful Carp-like Goby is commonly found in creeks and ponds in coastal parts of New South Wales and Southern Queensland. In the upper parts of Cook's River, and in other creeks around Sydney, it is quite common, though not so abundant as the Striped Gudgeon. It varies in colour from a very pale gold to a rich red coppery-gold; the male being very brilliant at the spawning time.

This species is an excellent aquarium fish, and usually swims in mid-water; while the other Gudgeons, which also make fine aquarium pets, are ordinarily bottom-swimmers.

The Carp-Gudgeon grows to a length of about 4 inches.

The Mud-Skipper: Many of my readers will, no doubt, have heard of, while some will have often seen, those curious little fishes which hop and skip about the mud- and mangrove-flats on the coast of Northern Queensland; often, even climbing the sloping boughs and exposed roots of the mangroves themselves. This is the "Mud-Skipper," known in some parts of Queensland as the "Climbing Fish." Upon examination, two points will at once strike the observer; 
these being the prominent eyes, placed close together at the summit of the head, and the large pectoral fins with their highly-muscular bases-with which their hopping and climbing are chiefly accomplished. In the words of Saville-Kent. the Mud-Skipper "is an essentially-tropical species, being particularly abundant among the muddy mangrove-flats of North Australia and the Malay region. Under these conditions, it may be commonly seen at low water associating in little groups and basking in the sum on the surface of the mud, chasing each other in sport with their quaint skipping action; or, having climbed to the elevation of a mangrove root or the woorlwork of the jetty, peacefully contemplating its companions' antics. 'The capture of the little fish seems at first sight an easy task; but woe betide the reckless enthusiast who ventures on the treacherous ooze in its vain pursuit. He will emerge from the enterprise with bemired raiment and a much-chastened spirit. Should, however, the acquisition of specimens be an important object, the enlisted services of the wily native-who needs but a little paint and a pearl-shell for the renewal of his full-dress apparel-will speedily secure an abundant supply.

"A remarkable circumstance associated with the life economy of Periophthalmus is the fact that it cannot sustain life if continually water-submerged like ordinary fish. The exposure of its tissues to the action of atmospheric air with every fall of the tide appears to be essential to its wellbeing, and examples experimentally kept under water for prolonged intervals were literally drowned. As a provision for its abnormal life-habits, it has been ascertained that Periophthalmus possesses a supplementary respiratory organ which, singularly to relate, is represented in this instance, in the creature's tail. The fish while reposing on the surface of the mud commonly leaves its tail more or less immersed in the water. The blood circulates with abnormal energy through this thin membraneous appendage, which accordingly fulfils the function of a supplementary gill."

Periophthalmus australis grows to a length of about I 2 inches.

The Eel-like Goby is a fish which might be mistaken by many, for an Eel; but the presence of ventral fins will 
at once definitely settle any doubt that there may be, as those fins are absent in all Eels. It is a small fish, of a few irches in length, occurring on portions of the coastline of New South Wales and Queensland, living in the mud on the banks of the lower portions of the rivers. According to Castelnat, who described this species, the colour in life is a deep purple-red with a series of pale spots down the rijddle line of the body; the fins being dark with pale edges. Though as I have inferred, this fish is distinctly Eellike; still the long dorsal and anal fins are completely separated from the caudal fin. 


\section{Chapter $\mathrm{X}$.}

The Sucking-Fishes-Scorpænoid Fishes-The Flatheads-Gurnard or Gurnets-Flying Gurnards or Sea Robins-Leptoscopoid FishesNotothenioid Fishes-The Star Gazers-Trichonotoid Fishes.

\section{THE SUCKING-FISHES.}

\section{(Family: Echencidide.)}

AMONGST fishes which are remarkable for peculiarity of habit and structure, the Sucking-Fishes certainly stand in the front rank. These curious creatures are provided with a long, oval, transversely-laminated, suctorial disk on the top of the head and by its aid, they are able to attach themselves to the bodies of Sharks and other large fishes or cetaceans. They are also known to attach themselves to the bottoms and sides of ships. Thus they are enabled to travel over vast areas with a minimum of muscular effort. Sharks are the principal "hosts" (if I may use the term) of the Sucking-Fishes, and hardly a large one is caught that has not 2 or 3 of the latter as attendants. Very often they remain attached when a Shark is hauled out of the water; great force being required to dislodge them, owing to the wonderful way in which they adhere. 'The sucking-disk by which this adhesion is brought about, is a very remarkable organ. It possesses a long central longitudinal division anil numerous short transverse ones: The number of these transverse divisions, varies considerably in the different species, though the general plan of arrangement is always the same. The sucking or "cupping" action is produced in the same way as that of the suckers on the tentacles of the Octopus; that is, by the formation of a partial vacuum; in this case caused by raising the partitions dividing the various compartments of the disk. To give an idea of the great utility of this organ, I may mention that I have taken one of these Sucking-Fishes, even several hours after death, and applied the sucking-disk to a piece of smooth glass giving a clight 
even pressure all over. I then found that it was very nearly impossible to dislodge the fish by a direct steady pull without breaking the glass. In some parts of the world, advantage is taken of this habit of attaching themselves to larger marine animals to use them-particularly the large species. Echeneis naucrates-in the capture of turtles. This is done by fastening a line to a metal ring fastened round the tail of the fish, and allowing it to swim about in waters where the turtles are known to commonly occur. Sometimes turtles are found asleep; and in that case the boat is pulled up as close as possible, and the Sucking-Fish is launched; soon to attach itself to the breast (or plastron) of the sleeping turtle, when they are both drawn in together.

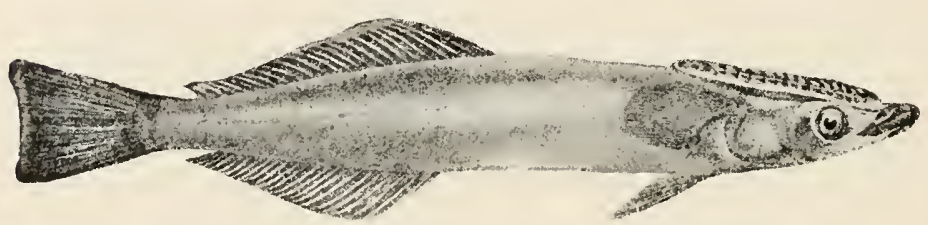

Fig. 67.--Sновт Sucking-Fish (Remora remora).

One of the Sucking-Fishes was the celebrated echeneis of the Greeks: famous from remote antiquity for its power of adhesion to other bodies. Pliny and other ancient naturalists relate among other stories, that Antony's ship, at the battle of Actium was kept motionless by the exertions of the echeneis, notwithstanding the efforts of several hundred sailors; and that the vessel of Caligula was detained between Astura and Actium by another of these fishes found sticking to the helm, and whose solitary efforts could not be countervailed by a crew of four hundred able seamen, till several of the latter, on inquiring into the cause of the detention, perceived the impediment and detached the fish from its hold. Now, although it would be altogether impossible and out of all reason to suppose that one individual could exert sufficient power to delay or retard a vessel's progress, still an instance has actually come under my notice, in which a sailing-vessel was considerably delayed while in 
tropical seas through a shoal of "Suckers" attaching themselves all round the sides and bottom.

Two species of Sucking-Fishes occur commonly in Australian waters, particularly on our eastern coast. These are the Long Sucking-Fish (Echeneis naucrates) and the Short Sucking-Fish (Remora remora). The former reaches a length of 3 feet. It is of elongate form, is of a dark-brownish colour, and has the central portion of the caudal fin very much rounded. The latter is a small species, commonly attaining a size of 8 to Io inches, is relatively stouter in build, of a greyish colour and possesses a forked caudal fin.

The "Suckers" are carnivorous, usually subsisting upon other fishes.

\section{SCORP ÆNOID FISHES.}

(Family: Scorpcenida.)

THIs is a large family of carnivorous marine fishes, embracing about 250 species. Included in their number are some of the most extraordinary-shaped fishes imaginable; in fact some of them surpass the wildest flight of an overheated imagination and look altogether "impossible." Among the various species are to be seen hideously-distorted heads (Glyptauchen, etc.), tremendously-elongated fins (Ptcrois, etc.), skins covered with curious weed-like appendages (Scorpena, etc.), and in nearly all of them the head is set with more or less dangerous spines, some of which are erectile.

Amongst the Australian species the most noticeable are the Red Gurnet-Perch (Scbastapistes percoides), the Red Rock-Cod (Scorpena cruenta), the Bullrout (Notesthes robusta), the Fortescue (Centropogon anstralis), the curious Goblin-Fish (Glyptauchen panduratus), the Red FireFish (Ptcrois a'olitans) and the Velvet-Fish (Aploactis 
milesii). Of these only the first three are of economic importance, the principal one being the Red Rock-Cod.

The Red Gurnet-Perch is not uncommon along the coasts of New South Wales and Victoria, being also found in Tasmania and New Zealand. In Tasmania it is known as "Rock Gurnet," while in New Zealand, where it is quite common, it is called "Sea Perch," or the Maori name of "Pohuiakaroa." In shape, it is somewhat like the Red Rock-Cod, but its form is devoid of the fleshy weed-like filaments which adorn the head and body of that species. Also, the head of the Red Rock-Cod is scaleless, while in the Red Gurnet-Perch, that portion down to the space between the eyes, is covered with scales. Other differences also exist.

In colouration, this species, like so many scorpænoid fishes, is very beautiful; but it requires to be seen while fresh to be properly appreciated. 'The following description is chiefly from McCoy. It will be found to apply fairly well in most cases, though there is a certain amount of variation.

Colour: variable; cheeks, sides, tail and upper part of body orange, scarlet or vermilion, and carmine-red; dotted or minutely-spotted with blackish-brown; rendering the top of the head and the middle of the back darkest. On the sides are four irregular, broad, dark transverse bands, the first two not reaching to the abdominal profile and the last of which crosses the base of the caudal fin. These bands are formed by a confluence of the more numerous blackish freckles of the upper part of the body; a few of which are also scattered between the bands. All the fins are of a vermilion, tinged with orange on the rays; the membranous portions of the dorsal, caudal and pectoral fins being palepurplish, the dorsal being strongly speckled with black at its base especially over the dark body-bands. The membranes of the ventral and anal fins are orange. In front of the pectoral fin and along the lower part of the sides is a yellowochre tint separating the red of the upper part from the pearly white of the throat and, belly.

Occurring as it does in fairly-deep water in rocky 


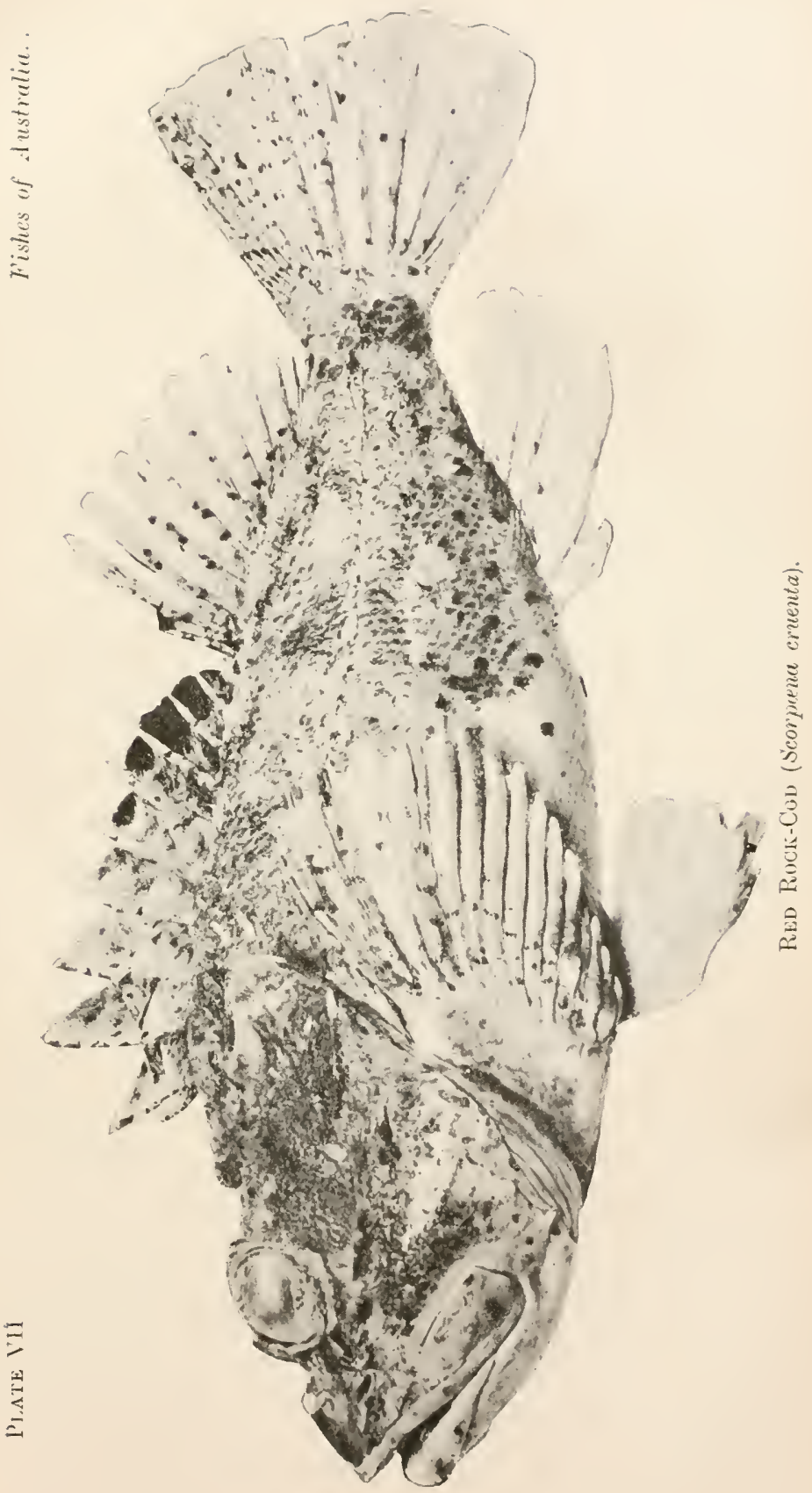



situations the Red Gurnet-Perch is usually only captured by hook and line.

It nsually attains a length of about 12 inches but at present is not greatly esteemed as food.

The Red Rock-Cod is found along the greater partif not the whole-of the eastern coast of Australia, abounding also in 'Tasmania. It is a very grotesque-looking fish; having a large heavily-armed head, covered with ridges and spines. The eyes are large and between them is a deeplyconcave space. Distributed over the head and body at intervals, are numerous short skinny appendages. The spines of the dorsal and anal fins are strong and aente.

The colours of the Red Rock-Cod are very beautiful. The general colour is a rich cammine-very bright towards the back; while the lower parts are a pearly-white. 'There is a broad transverse pink spot, which is narrowest in the middle immediately at the back of the head on the occiput. The lower surface of the head is a pale red marbled with yellow with which colour the lips are banded. On the sides are scattered many dark chocolate-coloured spots, particularly over the lower portions.

This species is a rock-fish, being captured by hook and line with a flesh-bait on ontside reefs and bomboras in fairly-shallow water along our coastline, being very abundant in the vicinity of Port Jackson. It is a very voracious fish, subsisting upon crustaceans, mollusks and other marine animals that are to be found in the vicinity of weedy-rocks. As food it is considered to be of value, as its flesh is of good flavour.

Thongh the Rerl Rock-Corl is more often seen of a length of from io to $\mathrm{I} 2$ inches, it attains at least 18 inches.

The Bullrout though an edible fish, is famed chiefly on account of the painful wound which it inflicts upon the unwary handler by means of the strong, sharp preorbital spines; one of which is short and triangular, while the other is long and thorn-like. The fisl is able to erect these spines at will, when they become really formidable weapons of defence.

In colour this fish is brownish, marbled with black. 
Often the black is arranged in the form of broad, irregular, vertical bands.

The possession of such an ugly head coupled with its known power to cause such nasty wounds, has brought about in many people a strong feeling against using this fish as food and has even given rise to an idea in some quarters that the flesh is poisonous, but such a fear is altogether unvarranted, as the Bullrout is usually both wholesome and palatable.

This species is one of those which, while occurring commonly in the upper portions of our harbours and estuaries also penetrate far up into the fresh-waters of our eastern rivers. When in fresh-water it ustially assunies a more dingy tint. It loves to lurk in weedy patches, from where it dashes out suddenly upon its prey.

Thongh occurring more commonly in New South Wales waters it is also found along part of the eastern coast of Queensland and probably in Victoria.

It attains a length of about 12 inches, examples of 8 to Io inches being more commonly seen.

When captured this fish emits a loud and harsh grunting sound.

The Fortescue is somewhat similar to the preceding and is often considered by fishermen and others to be merely the young of the Bullrout; but this idea is altogether wrong: as, of course, this species is quite distinct. The Fortescue inhabits, by preference, bottoms covered with marine growths; such as are to be found near to and inside the entrances to some of our harbours-notably that off Vaucluse in Port Jackson. Its head is even more heavilyarmed-that is relatively-than its larger congener; the spines being longer and still more acute; and, like the latter, it uses this armature to produce very painful stinging wounds.

In colour, this species is much lighter than the preceding, being of a light yellowish-grey with dark vertical bands at intervals along the body.

Though the Fortescue attains not uncommonly a length of 6 inches, the size of those more usually seen is from 3 to 4 inches. 
It is most abundant on the coast of New South Wales, and is known to occur along the coasts of Queensland and Victoria.

The Goblin-Fish is one of those remarkable animals that appear more like creatures of a frenzied imagination ratlier than perfectly normal natural productions. Such a grotesque shape it would be trily difficult to imagine. Space will not permit me to here describe this fish in detail, but I may mention in passing that it reminds one of nothing

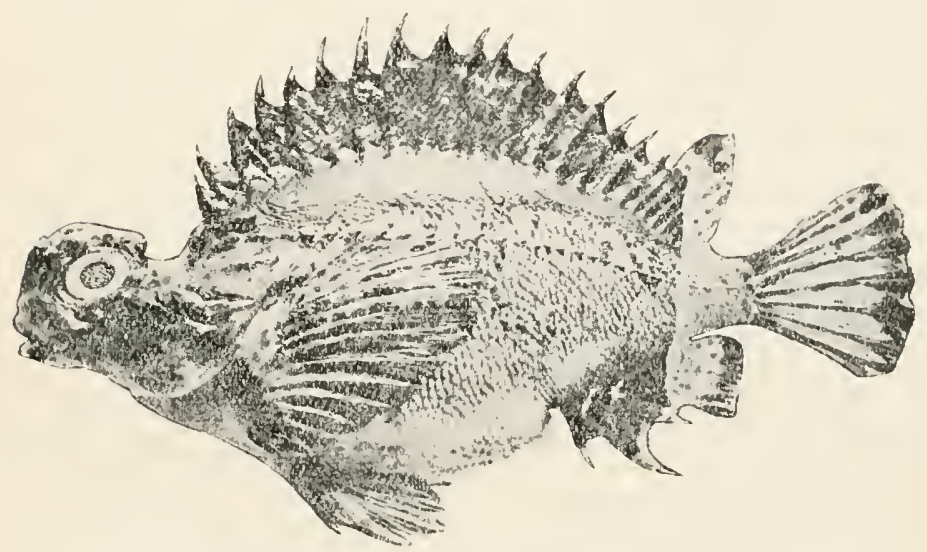

Fig. (w)-GomLin-Fish (Glyptauchen panduratus).

so much as an unfledged parrot. It is a somewhat rare fish and is found on the coast of New South Wales, as well as the Southern seaboard of Australia. It attains a length of about 6 inches.

The Red Fire-Fish is remarkable for the tremendous elongation of the rays and spines of the fins. It is a brightly-coloured fish. It is really a tropical species, being uncommon on the coast of New South Wales.

The Velvet-Fish is an exceedingly curious-looking species. It has a very leathery skin covered all over with small protuberances suggesting in a way, velvet-pile; whence its name. Along each side is a row of larger protuberances. The ground colour of the body is a rich brown, while many of the papillae or protuberances are tipped with orange-yellow or red. 
This fish reaches a length of 6 to 8 inches. It is not very often captured, being a rock-weed frequenting fish: consequently being usually out of reach of the ordinary means of capture.

It possesses a fairly-extended geographical range within Australian waters.

\section{THE FLATHEADS.}

(Family: Platycephalidre.)

THE "Flatheads," or rather, such of then as are commonly found in our various fish marliets, being so well known to my Australian readers, little preliminary description of them is necessary. They all have broad depressed heads more or less armed with spines-in exceptional instances the spines being limited to the gill-cover only. The body, in the anterior part, is also flattish; becoming more rounded as it approaches the tail. In two or three of the species there is a slight departure from this rule, the body being comparatively narrow and slightly rounded; a familiar instance being the common "Rock Flathead" of our southeastern shores. Of about 40 species of Flathead which are at present known to exist, probably about one-third inhabit the shores of Australia; about one-quarter being found in New South Wales waters alone.

From an economic point of vicw, these fishes are of very great importance, providing as they do for very many people an excellent and readily-obtainable article of food.

In parts of India some of the Flatheads are known familiarly as "Crocodile-Fishes."

As before stated, the head is usually armed with spines. The most prominent of these are those on the gill-cover which are situated at the base of the preoperculum; in some of the species these preopercular spines being very acute, long and powerful. All of the species are able (and willing) to inflict very nasty, painful wounds with these 
weapons: and those persons who have the catching and handling of them are always careful to avoid being struck.

Mlost of the species of the Platycephalide inhabit waters lying inside the "hundred-fathom line," many being found in quite shallow water; there is one species however which occurs in Japanese waters at a depth of about 500 fathoms.

By far the most important Australian kind is the Common or Dusky Flathead (Platyccphalus fuscus); others that might be mentioned being the Rock Flathead (Platycephalus lavigatus), the Long-spined Flathead (Platyccphalus longispinis), and the very grotesque-looking Variegated Flathead (Platyccphalus cirronasus).

The Dusky Flathead is very abundant along the coast of New Sonth Wales, being also found more or less abundantly in the waters of Queensland. Victoria, Tasmania and South Australia. It is found most plentifully in water of from 3 or 4 fathoms in depth up to a few inches at low tide.

It is one of the largest of the Flathead family, specinens of a length of 4 feet being not unknown; those of a length of 2 to $2 \frac{1}{2}$ feet however, are considered ordinarily large, while the arerage of those marketed would be mutch less than that.

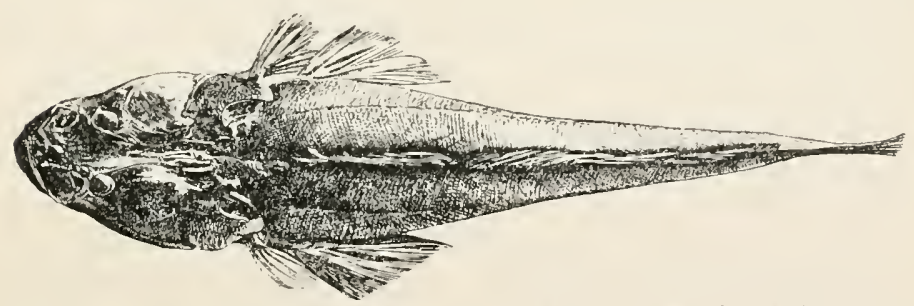

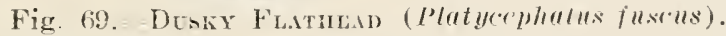

This species is most "at home" on the bottoms of muddy channels and on mutl- or mud-and-sand-flats. At low tide one may often see numbers of these creatures lying on the flats, basking in the sun, with only their eyes showing. It is really wonderful, how quickly they are able to bury themselves. One may dart from "under your nose" to a short distance away, there is a quick grovelling, fattning motion and the fish has virtually disappeared from view. Of course, the fish is very materially assisted by the 
wonderful assimilation of its colours to the prevailing hues of whatever bottom it is on: on muddy bottoms being a dirty brownish-black with transverse bars of black, while in sandy places a light sandy-grey is assumed.

The Dusky Flathead is exceedingly ravenous; nothing much in the way of animal food coming amiss to it.

It is onie of the commonest of our food-fishes, the flesh being of good flavour and much appreciated.

The Rock Flathead is more particularly a Victorian fish, being more common on that coast. It is not uncommon on the most southern portions of the New South Wales coast, but is rarely obtained as high up as Port Tackson. It occurs also in Tasmania, (?) South Australia, and Western Australia.

If one took a rubber duplicate of a typical Dusky Flathead from New South Wales, and stretched it out so that it became relatively much longer, narrower and rounder he would have a very fair resemblance to the Rock Flathead.

In its colours it is somewhat similar to the Dusky Flathead, but the sides are very prettily mottled with white anil when fresh there are very distinct dark crossbands.

This species is considerably smaller than the preceding, growing to a length of less than 2 feet.

The Long-spined Flathead is a small, large-bellied species, occurring on the coast of New South Wales. It is not uncommon on sandy patches in deep water off $d$ number of the beaches in the vicinity of Sydney.

In this Flathead there is a great development of the lower of two preopercular spines (on each side) this being exceedingly large and sharp. From this character, the fish is known to the fishermen of Coogee by the very appropriate name of "Spikey."

This only attains a length of about I 2 or I3 inches, even that being considered very large, and it is sexually mature at a length of 7 or 8 inches.

It is of a light sandy colour, spotted over with small, brilliant, red or vermilion spots.

The Variegated Flathead I have included solely because of its remarkable appearance and beautiful colours. 
It is a native of New South Wales, where, partly because of its habits, it is not often obtained.

It is a short, thick-bodied Flathear. The scales are rougly and the head is covered with prominent ridges and spines. 'The colours are very brilliant, being very similar to those of the "Red Rock-Cod" and like that fish it has a number of skinny tentacles growing upon its head.

It grows to about i 5 inches in length, but is not obtained in sufficient numbers to be used as food.

\section{GURNARDS OR GURNETS.}

(Family: Triglide.)

THE Gurnards are well-known to most people, their weilarmed or well-armoured "bull-heads" or the beautiful butterfly-like "wings" being faniliar objects to most people. In species they are fairly numerous, occurring in considerable numbers in most seas lying within the tropical an:l temperate zones, and inhabiting water ranging from a few feet down to moderate ocean deptlis. Many of the species are possessed of the most magnificent colours while the: are alive and in their natural surroundings. They may be observed to great advantage in an aquarium, where their movements will be found to be most interesting. One of their principal characteristics, noticed by all authors dealing with these fishes, is the three curious finger-like pectoral rays below each pectoral fin, from which they are quite free: acting in quite an independent manner. The ventral fins are sometimes very large, but it is the pectorals which especially claim our attention; these being frequently c $x$ ceedingly large, membranous and wing-like, and ornamented with the most brilliant and indescribably-beantifui colours. Normally, these beantifully-coloured thoush grotesque-looking fishes frequent the bottom, upon whici? they crawl about, using their free pectoral rays-which may 
be curved somewhat like fingers-as a kind of legs; but at times certain of them seek the surface waters, from which they take short flying-leaps (with their pectoral fins spread out), skipping over the surface for considerable distances. From this habit equally with their possession of the large pectorals various species in different parts of the world have derived the name of "Flying Gurnard"-a name, however, which it is better to restrict to the "Sea-Robin" or Dactylopterus (page 202).

Amongst the Australian Gurnards may be mentioned the Red or Kumu Gurnard (Chelidonichthys kumu) and the Sharp-beaked Gurnard (Ptcrygotrigla polyommata).

The Kumu Gurnard is an inlabitant of many waters; having a very extensive geographical range. It is foumd along the whole of the eastern coast of Australia as weil as in Tasmania, and has been recorded from Western Australia. Outside of Australia it occurs in the waters of New Zealand (where it is abundant), South Africa, the Malay Archipelago, China and Japan. It appears highly probable that it will be found to be distributed in suitable localities right rounrl Australia. Along the coast of New South Wales, this Gurnard is quite common: though, as it frequents rough ground, it does not often come within the scope of the fisherman's net and consequently is not brought to the markets in any quantity. Young examples are con1mon on bottoms around rocky headlands in places like the lower parts of Port Jackson,* being occasionally captured by "prawners" using a sunken-net.

The upper parts of the Kumu Gurnard and the sides of the head are of a reddish or reddish-brown colour; the lower surface being whitish. The large fan-shaped pectorals are exceedingly beautiful, but nutust be seen to be properly appreciated.

In New Zealand this is known by the Maori name of Kumuı (or Kumukumu) and I have here used that prefix in preference to that of "Red" as the latter is rather misleading; the Sharp-beaked Gurnard, though very different, having a tint of red also as the prevailing colour.

The Kumn Gurnard is an excellent table fish, and

"Ogilby was evirlently mot familiar with this fact, as he stated in his "Erible Fishes" (page 110) that "the fry are never seen in our harbours." 
grows to a length of twenty inches, though those brought to market are usually consiclerably below that size.

The Sharp-beaked Gurnard has a consicierable distribution along the southern half of the Australian coastline. being found in the waters of New South Wales, Victoria, (?) south Anstralia, Westen Australia and Tasmania. It is usually termed by amateur fishermen and others "Flying" Cinnarr, a name which-as previously pointed ont-is more correctly applied to another fisl.

In this species the head is rery heavily armed, there being two large and powerful. flattened spines projecting in front of the snout and four others which are long, rounded and acute, at the back of the head (two on each side), there being also two or three short blunted ones on the lower part of the preopercle on each side. In adclition to all these, there is a very long and strong, ridged spine on each side 11pon the clavicle, above the pectoral fin. The eyes are very latge and are situated right at the top of the head, there being a deep concave space between them.

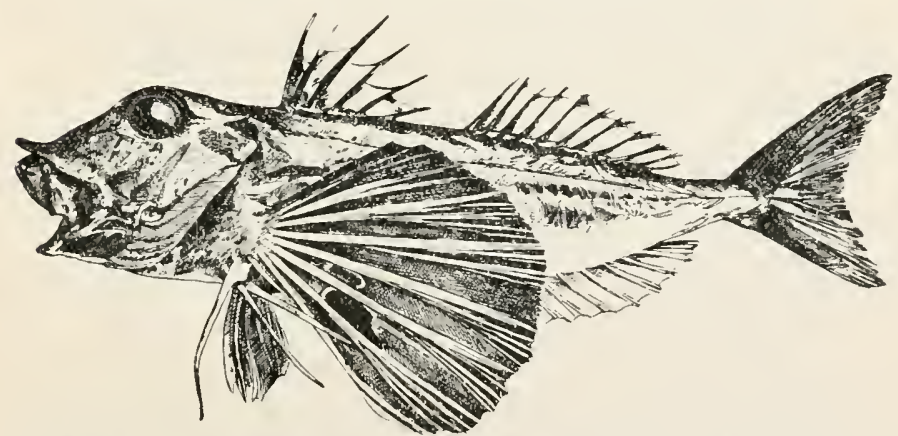

Fig. Tl.- SHARP-BEAKED GURNABn (l'teryghtrigle polyommate).

The general colour of the Sharp-beaked Gurnard is a beautiful reddish-pink; the lower parts being whitish, while along each side is a broad silver band.

It grows to a lengtl of about twenty inches.

This fish is fairly common on outside sandy gronnds in moderately-deep water along the New South Wales coast, at least as far up as Canden Haven. It is captured br means of hook and line with a flesh bait. Considerable 
quantities are caught by professional fishermen in the offing at Coogee (near Syclney). In regard to their capture in Tasmanian waters. Johnston (quoted by Ogilby) wrote in I882, as follows: "At times during the winter season, these beautifully-coloured fishes, with their gaudily-painted pectoral wings, may be seen around our wharves in small schools, dashing, or rather flying, through the water with sudden bounds, after their prey. ... They are rarely captured however, on our coasts; and are, therefore. unimportant here, from a commercial point of view." Though, the foregoing quotation is of interest, it is not correct to describe the pectoral fins as "wings" nor their mode of progression out of the water as "flying."

Though the Sharp-beaked Gurnard has been twice recorded from Western Australia, little is known of its occurrence in the waters of that State.

\section{FLYING GURNARDS OR SEA-ROBINS.}

(Family: Cephalacanthider.)

In these fishes, the hcad is a parallelopiped; the upper surface and the sides being entirely hard and bony. From the hinder portion of the head, on each side, there is an enormous spine pointing backwards. The pectoral fin on each side is so greatly enlarged as to almost form a kind of wing. The principal one amongst these fishes, and that which :s found on our coasts, is the Flying Gurnard or Sea-Robin (Cephalacanthus spinarclla). These fishes and the true Flying-Fishes are the only fishes which are enabled by their long pectoral fins to take sustained flying leaps out of the water. When young, the pectoral fins of the Flying-Gurnard are much shorter: and, consequently, the fish is unable to raise itself from the water. On our coast, this species attains a length of 12 or more inches.

(In connection with the technical name of this species, it is worthy of mention that the fish will usually be found 


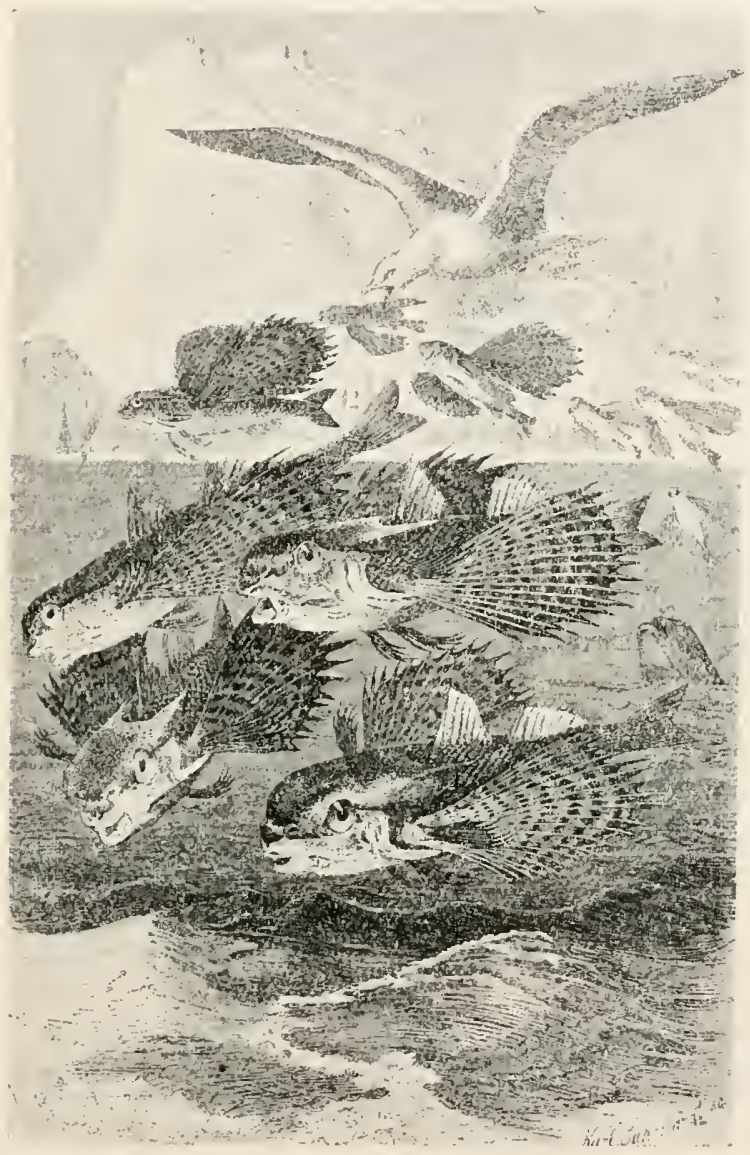

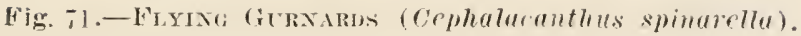


referred to in past literature under the name of Dactylopterus orientalis).

\section{LEPTOSCOPOID FISHES.}

(Family: Lcptoscopida.)

Tuाs family is remarkable, in that it includes the largest known deep-sea Teleostean fish-Macrius amissus-an imperfectly-known species, which measures 5 feet in length and was obtained at a depth of rooo fathoms in the Pacific Ocean. Another noteworthy fact, is, that one of the smaller fresh-water species, lives in alpine torrents in New Zealand. According to Boulenger's arrangement about 25 species are inclucled in this family, ranging from the tropies to the Antarctic Circle. One species which was taken home by the Sonthern Cross Fxpedition was captured in $78^{\circ} 35^{\prime}$ S.

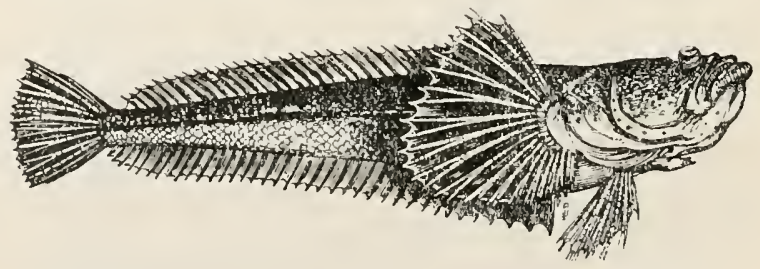

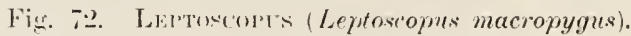

lat., the farthest point at which fishes have yet been obtained in the Antarctic region. Perhaps the most noticeable Australian memher of this family is the fish known as Leptoscopus macropygus-a kind of "Star-gazer." This is an excedingly curions-looking fish, having a large, broad head, which is entirely covered with a thin, soft skin; the body being elongate and covered with small scales. The scales of the lateral line are twice as large as those of the adjoining series, a fact that is worthy of note as it is of great assistance in the identification of this fish. There is 
one long, low dorsal fin: with a still longer anal fin and a broad fan-like pectoral.

The gill-cover is marmed-there being none of those nasty dangerous spines which are to be seen in the Stargazers of the family Uranoscopide.

In colour, the upper half of the head and body are olive, mottled with brown; the lateral line being also brownish.

This species has been obtained in Port Jackson-where it is rare-and also in New Zealand; on the coasts of which it is more common.

\section{NOTOTHENIOID FISHES.}

(Family: Nototheniidce.)

THIs rather unimportant family is composed of fishes obtained chiefly from the Sonthern Hemisphere, some being from the Antarctic regions. (Of the Australian species, the most important is the little Whiting-like fish known in South Australia and Tasmania as Sandy* (Pscudaphritis urillii). It is common in the lower parts of the Murray River (in South Australia) and in Tasmania; occurring also in Victoria and New South Wales. The curions-looking fish known as Bozichthy's ariegatus, which is found on the coasts of both New South Wales and New Zealand, is also a member of this family.

\section{THE STAR-GAZERS.}

(Family: Uranoscopida.)

About I 5 species of these curious and srotesque-looking creatures are known from various parts of the world. They are remarkable for the large. broad and thick head, which is partly covered with bony plates, the cleft of the mouth pointing upwards almost vertically. The eyes are very

\footnotetext{
* Known commonly on the Lower Mnray by the vative name of "Congolly."
} 
small and can be raised or depressed at will. Of sluggish rlisposition, as befits their structure, they generally remain hidden away at the bottom of the waters they frequent, lurking in some cases amongst rocks and in others burying themselves in the sand; the eyes and the edge of the month (nlly being uncovered-only being visible, I was about to say, but that expression would hardly apply; as, owing to their protective colouration, it is almost impossible to distinguish any of these fishes when at rest in their natural surroundings.

Amongst the Australian species may be mentioned the Mottled Star-gazer (Anema inerme) and the Stone-lifter (Kathetostoma lave).

The Mottled Star-gazer is a native of the coasts of India. Ceylon, Japan and Eastern Australia. Along parts of the northern half of the New South Wales coastline it is not uncommon though rarely captured. Though "haulingnets" are often drawn over the kind of ground frequented by this species, it is enabled to escape capture by its habit of burrowing into the sand-the net passing over it. Lurking quictly and craftily in this position, it snaps up the unwary searcher for such delicacies as "pippies" and sand-worms. The mouth has a curious fringed appearance, this assistiny to deceive its prey. Recently there passed through my hands a specimen of this Star-gazer, which had been found lying dead. buried in the sand at Pelican Island, Brisbane Water (N.S.W.). and jammed tightly by the head in its mouth was a fair-sized Black Bream, also dead. Here was revealed a rather pitiful tale. Nemesis had at last overtaken tile crafty one; like most villains he had at last attempte 1 too much and had "fallen in." All of the upper surface of this fish is very prettily marbled or mottled with black and white, with occasionally, several distinct, dark cross-bands. In addition to being found in shallow water, it is interesting to note, that the Mottled Star-gazer was trawled from the "Thetis" in I 898 off the coast of New South Wales at a depth of from 63 to 75 fathonns-showing that it possesses quite a considerable bathymetrical distribution.

In India, it is known in parts by the appropriate native 


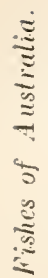
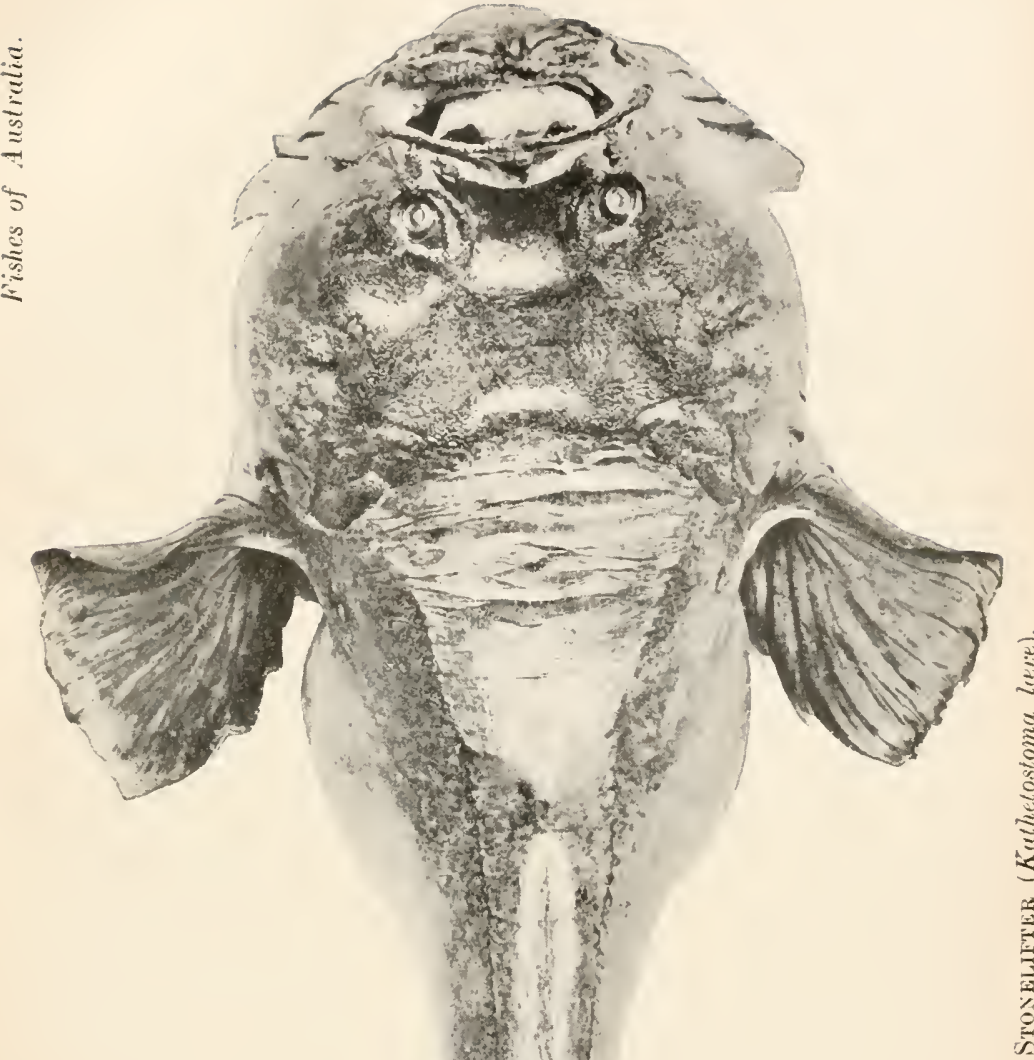

$\leqq$ 

name of "Nillum koranjan"; meaning "a diver into the mud."

On the coast of New South Wales it reaches a length of about 15 inches.

The Stone-lifter: This species is still more quaintlooking than the preceding: though in its shape it is verv similar. The upper parts of the head are very strongly armoured and there are two long, acute and strong spinesone on each side-at the back of the head over the pectoral fins. There are other spines of a less dangerous character underneath the head. The ventral fins in this-as in the mottled Star-gazer-are very large and strong; and are used principally in the process of burrowing.

This fish is of a yellowish colour with, usually, two or three broat lark bands.

In the waters of Victoria and Tasmania it is quite plentiful, but is rather uncommon in those of New South Wales. It, also, is found outside of Australia.

In Tasmania it is known as the "Cat-Fish." The name of "Stone-lifter" has been derived from the habit credited to this species, of burrowing under stones.

It attains a length of about 20 inches.

\section{TRICHONOTOID FISEES.}

(Family: Trichonotida.)

Tinss are small elongate fishes which are very nearly related to the Dragonets. All of them are marine. Three species, of which the names are here given, are known to occur in the waters of New South. Wales; viz.: Creedia haszeelli, Limichthy's fasciatus and Schizochirus insolens. From an economic standpoint they are of 110 value. 
Chalter Xi.

The Iragonets or Skulpins--The Cling-Fislies-The Blennies-The Frog Fishes -Zoarcoid Fishes-The Australian Rockling - Ribbon-Fishes - Angler-Fishes or Fishing-Frogs-The Leatherjackets or FilefishesBox-Fishes or Trunk-Fishes-The Toad-Fishes-Sea-Porcupines-The Sun Fishes -Lung-Fishes

\title{
THE DRAGONETS OR SKULPINS.
}

\author{
(Family: ('alliony'mider.)
}

THESE are small marine fishes. Some of them are very beautifully marked; particularly-in many cases-the males. Mature males of a number of the species often have the fin-rays prolonged into filanents, the fin-membranes being brightly ornamented. There is a large, 11sually hooked and barbed spine, on each side of the head, at the angle of the preoperculnum. The gill-openings are very narrow, being generally reducerl to a small opening or "foramen" at the

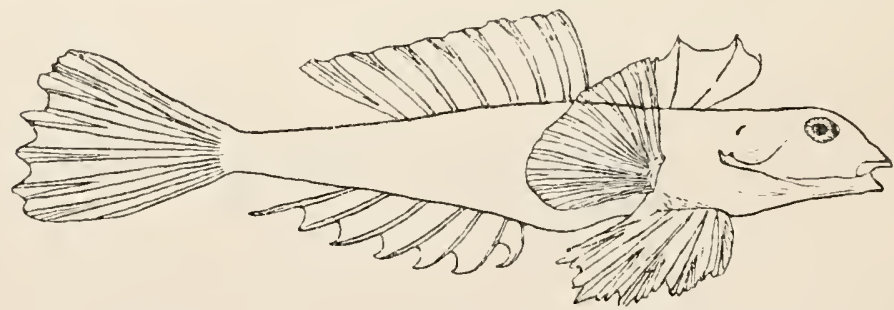

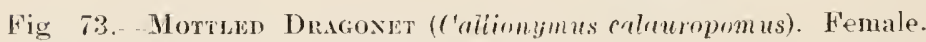

back of the head, on the npper side of the operculum or gill-cover (opercle).

Quite a number of species of Dragonets are known to inhabit the waters around the coastline of Australia. One species well-known in Port Jackson (because of the offensive smell exhaled from the gill-openings) is the Stink-Fish (Callionymus curvicomis). It is a mottled, greyish, sandycoloured fish; and, glanced at from above, appears something like what it is often mistaken for-a small Flathead. How- 
ever, it may be at once distinguished from any of the lilatheads, by the tiny gill-opening and the small month.

Another species that is worthy of note is the Mottled Dragonet (Callionymus culauropomms). In this species, the tail of the male is produced into a long filament. The gill-openings are comparatively large and the large spine of the preopercle is bifurcated at the extremity and curved upward.

Tn colour it is brownish above, clonded with darker mottlings. The snout and cheeks are rather prettily spotted.

The Mottled Dragonet grows to a length of $j$ or $i$ inches (exclusive of the caudal filaments).

The illustration is taken from a female specimen.

\section{THE CLING-FISHES.}

(Family: Gobiesocide.

"THE Cling-Fishes are curious small, carnivorous, marine fishes, usually found between tide-marks among loose stones and shells, to which they adhere firmly by means of the adhesive ventral disk. They can live for a long time ont of water. About 50 species are known from various parts of the world, extending as far north as Scotland and Vanconver Island and southwards to New Zealand."(Boulenger.)

The Australian Cling-Fish (Diplocrepis costatus) is a tiny species occurring on the coast of New South Wales, as well as at Lord Howe Island. The ventral disk in this species-as in the others also-is large and almost circular; being divided into two parts. It is situated between the ventral fins. The body is without scales. 


\title{
THE BLENNIES.
}

\author{
(Family: Blenniide.)
}

THE Blennies form a very large family. Most of them are very small and very curious-looking fishes. They are nearly all shore-frequenting fishes; consequently, most of us are quite familiar with the appearance of one or other of them, even if we are not always able to recognise the species to which they belons. They are distributed abundantly in all temperate and tropical seas-a few having become adapted for an existence in fresh-water. Although they may be quite properly termed "a family of Gullivers" there are amongst them a few "Brobdingnagians." The greatest of these is the ferocious Wolf-Fish (Anarrhichas lupus), called also the "Sea-Wolf" or "Sea-Cat." This gigantic Blenny grows to a length of more than 6 feet and inhabits the northern seas of Europe.

Amongst the Australian Blennies, there is one of considerable economic importance. This is the so-called "Slippery" or River Blackfish (Gadopsis marmoratus), also known occasionally as the "Marbled River-Cod." Others that are worthy of mention are: the Joey (Lepiaoblemins geminatus), the Oyster Blenny (Petroscirtes anolis), the Crested Weed-Fish (Cristiceps macleayi) the Red-Indian Fish (Patcous fronto) and the Hairtailed Blenny (Xiphasia setifer).

The River Blackfish is, as its name implies, a fluviatile fish: being found abundantly in parts of Tasmania, Victoria, South Australia and New South Wales. I mention Tasmania and Victoria first, because they appear to be the principal home of this species. It is also one of the giant Blennies (though not nearly so large as that previously mentioned), attaining a length of more than 24 inches. At the same time, the arerage of those caught is not much more than half that size.

In country parts, this species is looked upon as being of considerable value as an edible fish; and as a sporting fish, it is of no mean order, taking the bait readily and "showing figlt." Like many fresh-water fishes it is car- 
nivorous, subsisting upon larval aquatic insects, worms, crustaceans, etc.

It must be distinctly understood that there is no affinity whatever between this fish and the Blackfish properly so-called. It should always be called the "River Blackfish" (the "River" being a more essential part of the nane than the "Blackfish") or else the "Slippery"; the

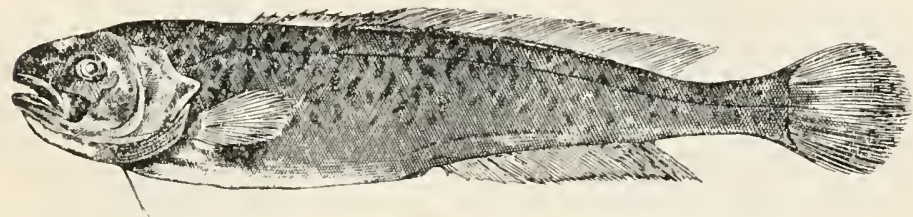

Fis. T4.-RIVER BlackFst (Gadopsis marmoratus).

latter being. perhaps, more preferable, as it is not likely to create any confusion in the observer's mind.

The Joey: All of you in New South Wales who have visiter the seaside, and have walked along the shoreline among the rock-pools, must have seen that pretty little variegated fish the colours of which, harmonise so well with the surrounding rock, and which makes short quick darts from one place to another; instantly, upon coming to a state of rest, being lost to sight: through its protective colouration. This is the little "Joey." Some people think that these are little "Flathead," but they have no affinity with the latter. The Joey is very common along a great portion of the New South Wales coast attaining a length of about 4 inches.

The Oyster Blenny: I have given this title to a very curious little fish (with a cassowary-like helmet on its head), which is very often to be found amongst dead and empty oyster-shells, along the coast of New South Wales. It is of a deep greenish colour, or sometimes blackish. The dorsal fin is very pretty and is very high, a little beyond the middle.

This little Blenny grows to a length of about 3 inches.

At any time of the year it may be found frequenting the empty oyster-shells; but, during the spawning season, larger numbers are to be found, as in the shells their 
curious eggs-which are demersal and adhesive-are deposited. These eggs are arranged in patches, one against the other, and not in masses, as are some demersal eggs. The whole story in regard to these eggs, their deposition, and the rearing of the young which hatch out from them, still remains to be told; but that it will be a very pretty story of paternal and maternal care cannot be doubted. The parents show great ferocity during the period in which the eggs are hatching, watching over them and driving away, or attempting to drive away, all intruders.

The Crested Weed-Fish: This very peculiar-looking fish, which has two dorsal fins (one of them being situated at the back of the head-hence its name), is, though seldom seen by the majority of even waterside folk, quite common in suitable localities along the eastern coastline of Anstralia, or at least in New South Wales. (If Castelnan's Cristiceps macleavi is synonymous with the $C$. australis of Cuvier and Valenciennes, as appears to be not altogether improbable, then the species exists in Victoria and Tasmania as well.)

The Crested Weed-Fish loves to dwell anongst weeds in fairly-deep water; either on sandy bottoms or amongst rocks; its pretty, mottled markings enabling it to escape the detection of predaceous fishes, and, at the same time, no doubt, assisting it to obtain its food, which is of an animal nature. As I have found, this little fish has a fairly-large stomach-capacity and it preys to a certain extent upon the "Little Rock-Whiting" (Odax balteatus) which frequents localities of a somewhat similar character.

This species, is of particular interest, because of the fact, that it brings forth its young alive, though they are very tiny.

It attains a length of about to inches, the more common size being from about 6 to 7 inches.

The Red-Indian Fish: I am sure that when any of you see an example of this most remarkable-looking species, you will think that the common name which I have chosen is very suitable, as the suggestion of a North American "Red Indian" with his crest of feathers running from the back of his head down his back, is most pronounced. Alto- 


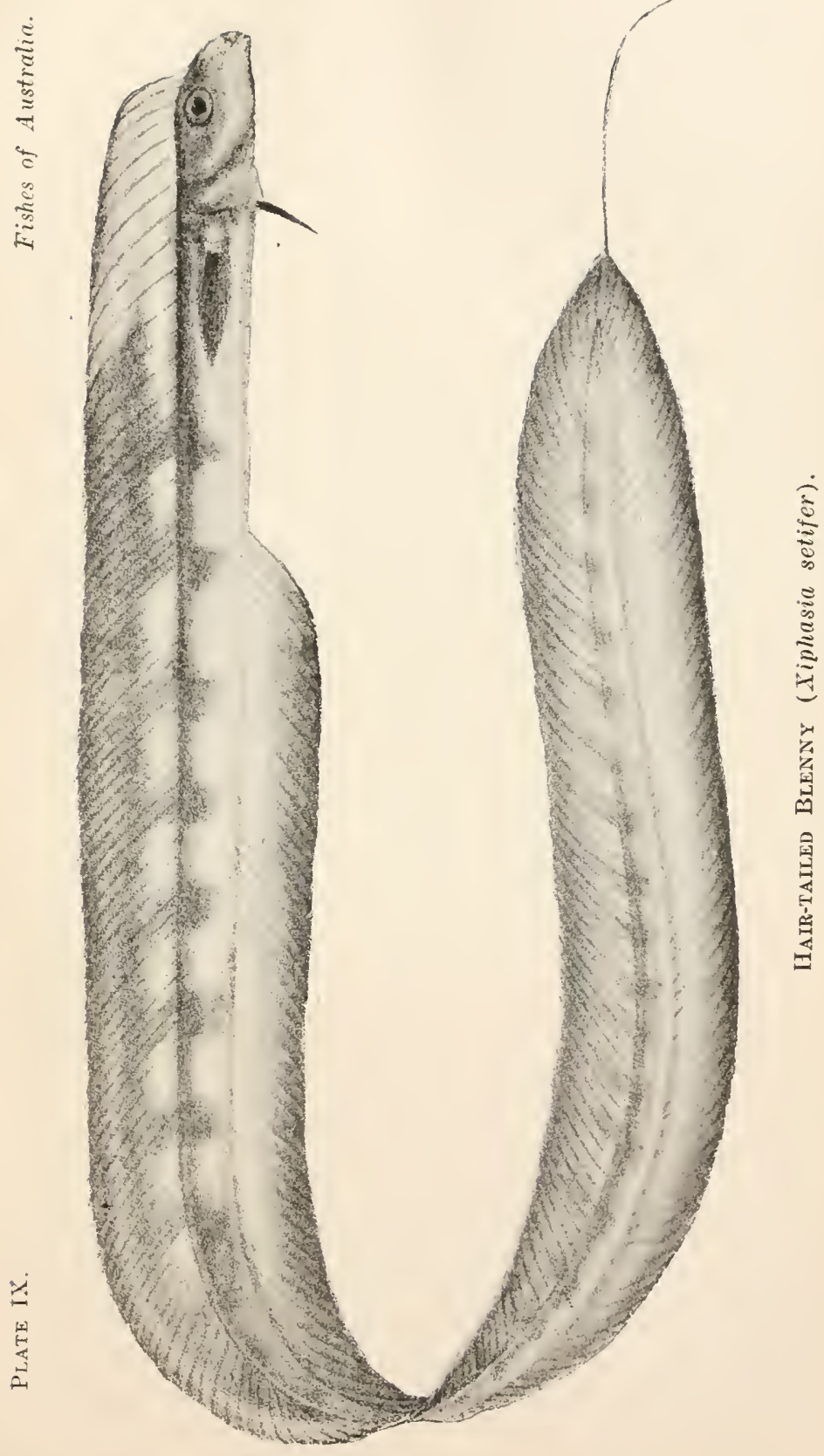



gether it is one of the most comical-looking fishes that swim. It is very high at the front of the head, from which the body tapers away rapidly down to the tail. The long and high dorsal fin begins immediately at the front of the head (where it is very high) and runs along the whole of the body, being connected by a membrane with the caudal fin. The anal fin is not connected with the caudal. The "face" is quite cadaverous-looking; in fact, the fish looks more like a caricature than a reality. When fresh the whole fish, with the exception of a few spots, is of a mostbeautiful reddish hue.

It attains a length of about 8 or 9 inches, and lives in weerly, rocky localities, along parts of the coast of New South Wales, having been also recorded from the shores of Western Australia.

I have seen some very handsome specimens from Port Jackson and Bondi, N.S.W.

The Hair-tailed Blenny: 'This remarkable-looking fish is an inhabitant of Indian seas and has been recorded from the coast of New South Wales, where it is exceedingly rare. It has a long, eel-like body; the tail ending in a long, fine filament.

Very little is known concerning this species.

It is said to be venomous.

The accompanying illustration, which is taken from a figure in Day's "Fishes of India," will serve to show what à quaint-looking fish this is.

\section{THE FROG-FISHES.}

(Family: Batrachide.)

'THESE are described as small, sluggish, voracious and carnivorous fishes, frequenting the shores of tropical and subtropical seas; some of them ascending rivers. They have broad and thick heads with elongate bodies, compressed posteriorly: the skin being either naked or with small scales. The most remarkable members of the family are two specics 
of Thalassophryne from Central America, in which the first dorsal fin is formed by two spines only: each of which is hollow (as is also a spine on the operculum), and convevs the contents of a poison-bag situater at its base into any wounds inflicted by the points of the spines. Wounds from these fishes are said to cause death and native fishermen are exceedingly careful to avoid standing upon them. A common representative of this family in Australian waters is the Frog-Fish (Batrachus dubius). This is often to be met with in Port Jackson and other localities. Apparently, it ranges from New Guinea to 'Tasmania. It is a squat-looking tadpole-like fish, having a smooth, soft, naked skin which, though darkly coloured, is rather prettily mottled. Small, tentacle-like weedy growths are placed all round the mouth and on other parts, these with the dark mottlings contributing to give to the fish a protective resemblance to the weed amongst which it is ustually found. Wounds inflicted by the spines of this fish are very painful. The Frog-Fish grows to a length of 6 or 7 inches.

\section{ZOARCOID FISHES.}

\section{(Family: Zoarcidae.)}

SPEAKING in a general way, this family of fishes is but little met with; consequently, with few exceptions, they are unfamiliar to the majority of people. They are widely distributed; many of them being adapted for an existence in great ocean depths. They have a more-or-less elongate body and there is usually no distinct caudal fin, the dorsal and anal fins forming-as in the Australian Rockling-one continuous fringing fin.

Included in this family are the curious Cave-fishes of Cuba, which are organised for an existence in subterranean waters-never coming to the light-the eyes being either absent or quite rudimentary, and covered by the skin: while others are found in depths of 2,500 fathoms (nearly 3 
miles). Two specimens only, of one species, linowin as Typhlonus nasus measuring io inches in length were dredged by the "Challenger" Expedition off the north-east coast of Australia at a depth of 2,440 fathoms. This is a very remarkable-looking fish, possessing curious protuberances formed by projecting portions of the cranium. occupying the upper and side surfaces of the head; there being also one in the front and another on each side of the snout, these being very conspicuous. In this species the eye is not externally visible, being reduced to a minute rudiment hidden below the skin.

\section{THE AUSTRALIAN ROCKLING.}

(Family: Ophidiida.)

THE members of this family are marine, carnivorous fishes from Atlantic and Southern Pacific coasts. as well as from great depths in the Atlantic, Pacific and Indian Oceans (Boulenger). About 25 species are known. They have usually narrow, elongate bodies and large heads and are chiefly of small size.

The only representative of this family of any importance, that is resident in our waters, is the Australian Rockling (Genypterus blacodes). This is a widely-distributed fish, in addition to its Australian habitat, being known to occur on the coasts of New Zealand, Chilé and Peru. A closely-allied species in South Africa is known as "Klipvisch."

The Australian Rockling is most abundant on the coast of Victoria, seldom being seen on any part of the New South Wales coast.* It is a comparatively-large, somewhat E.elshaped fish, growing to a length of over 3 feet. As in the other members of this family, there are no true rentral fins, these being replaced by a pair of bifid filaments or barbels, which are placed beneath the lower jaw. The pos-

* There is a fine example in the collection of the New South Wales Department of Fisheries, this being from Jervis Bay. 
session of these and of also such wide, open gill-openings, wonld enable the veriest tyro to at once distinguish this fish from any of the Eels; this is worthy of note, as there is some tendency for the uninitiated to confuse it with the latter.

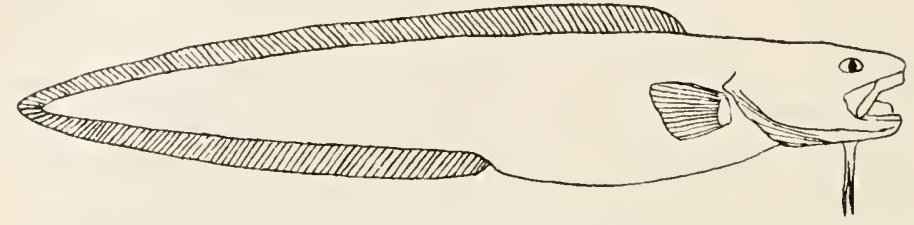

Fig. 75.-Australtan Rockling (Genypterus blacodes).

This species is stated to be not uncommon in the Me!bourne market, being moderately good for table purposes.

Though the Australian Rockling cannot lay claim to that gracefulness of form which is so apparent in many of our other fishes, its colours are very attractive. The head and body are of a rich purplish-brown above, with a delicate lilac tint, stronger towards the posterior end, irregularly marbled with confluent spots of dark vandyke-brown. The cheeks and the upper part of the iris have a rich copperyred, bronze tint : the lower part of the iris being silvery. The lower part of the body and the belly, are yellowish-white, without mottlings. The fins are also very nicely marked.

Before dismissing this species, I might mention that in New Zealand it is known as "Ling" and also as "CloudyBay Cod." It is quite common in Cook Strait and on other parts of the New Zealand coast to the southward. There. it is stated to attain as great a length as 5 feet with a weight of 15 to 20 pounds. Large numbers are captured by hook and line as the fish is very voracious, taking the bait greedily.

\section{RIBBON-FISHES.}

(Family: Tracliypteride.)

AT least two species of this very remarkable family inhabit Australian waters. These are the Southern Ribbon-Fish 
(Trachypterus jacksonensis), and the Oar-Fish, better known as "King-of-the-Herrings" (Regalecus glesne).

The Ribbon-Fishes have a band-like body, which may measure as much as ${ }_{5} 5$ or 20 feet in length, with a depth of $\mathrm{I}$ foot and a thickness of. often, not more than an inch. This terminates in a short and leep head possessing large "sancer-eyes" and a highly-protractile month, which, relatively-speaking, is not very large. 'The teeth are very feebly developed. There is generally a high dorsal fin, composed of a very numerous series of rays, which are neither articulated nor branched: and this fin runs from the back of the hear to the tail. There is a small detached portion on the crown of the head, elevated into tall filaments.

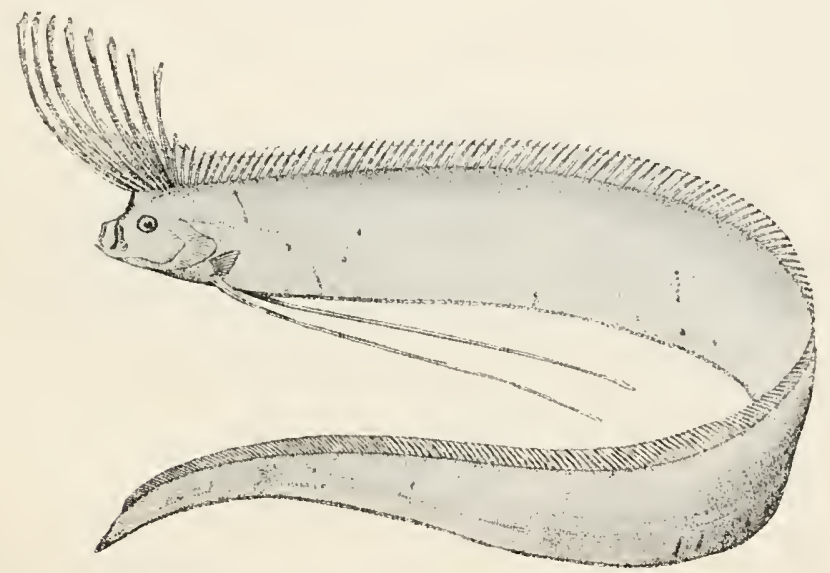

F'ig. 76.-OAR-Fisi (Regalecus glesne).

There is no anal fin and they do not possess any scales. The young, which are not unfrequently found at the surface of the ocean, are very unlike the adults, having the body more like that of an ordinary fish, but remarkable for the enormous development of the rays of the front part of the dorsal and ventral fins. The dorsal rays are often several times the length of the whole fish, and are furnished at intervals with barb-like expansions. Ribbon-Fishes are usually of a most brilliant, uniformly silvery appearance, with roseate fins. The Oar-Fish is so named becanse of the long oar-like ventral fins, while the name of "King-of-the- 
Herrings" was derived from the idea that it accompanied shoals of Herrings.

Dead or dying Ribbon-Fishes lying or swimming at the surface of the ocean, have, no doubt in some cases, been responsible for tales of sea-serpents. It is the Oar-Fisin which has been known to reach a length of 20 feet.

\section{ANGLER-FISHES OR FISHING-FROGS.}

(Family: Antennariida.)

Amongst the curious and remarkable beings that inhabit our waters, certainly not the least curious are the little Angler-Fishes, which are also known under various other names, such as "Fishing-Frogs" and "Walking-Fishes." There are quite a number of species of these in Australian waters, and they all have the same general habit of luring their prey to them by means of a contrivance on the top of the head, which acts as a fishing-rod and bait, so that here we have the artful human angler in piscine form. One of the species is jet black and has a crimson mouth. it lives in fairly-deep water, generally on a dark muddy bottom.

Without going into detail in regard to the various species, I will content myself with describing one of the most familiar examples-the little Striped Angler-Fish (Antennarins striatus). This is to be found living amongst the weed on the bottom in shallow and rather sandy parts, and is one of the quaintest-looking fishes imaginable. Its short, plump body, which, out of the water, feels very flabby to the touch, is covered with a rough, sand-papery, scaleless skin, the ground colour of which, is a light brown or a fawn colour; having all over it, rumning in all directions, dark-brown stripes of varying width and shape. The great contrast of these colours, would learl the observer, upon first vicwing it, to think that the fish must be a very conspicuous object in the water, but such is certainly not the case, as anyone may prove for himself. Even if one 
of these be placed on a sandy botton in clean water, it is hard to believe that it is not merely a variegated piece of seaweed. But it is when the fish is seen in its proper haunts, that the beauty of its protective colouration is apparent. Though I say "when it is scen" this can reallv only be if the fish moves about. Let it remain stationary, as is its habit; or, let the observer.turn his eves away for a moment, and he will certainly not be able to locate it again. There may be dozens at a time within actual visual range of a person, and he will not be aware of it 11nless they move fast-and what is fast for them is very slow for most other fishes. The wisual mode of progression (when that is necessary), is a kind of walking; the pectoral and ventral fins-particularly the latter-being so wonderfully modified, as to form a sort of legs. This fish is not at all

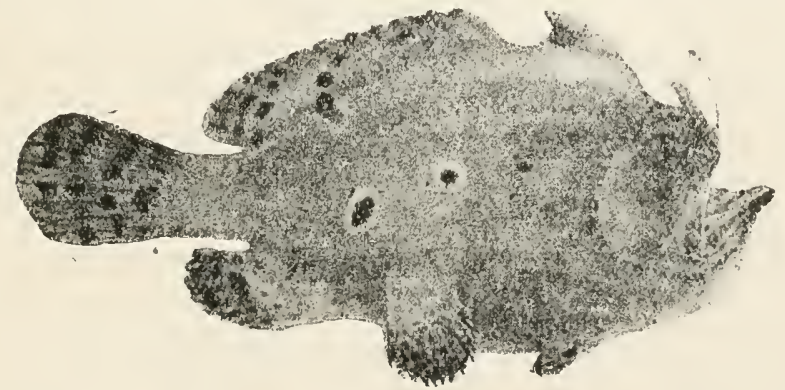

Fig. 77.-ANGLer-lish (Antenuurus nummifer.)

adapted for swimming freely in the water-like a Yellow. tail, for instance-nor does it attempt to ; excepting when it is necessary to travel from one weed-patch to another. The tail is very small, and not at all powerful enongh to drive the fish along at any speed.

'The food of the Striped Angler-Fish consists principally of active little Shrimps and Prawns-though small fishes are also occasionally taken. Now, to the average reader, who is unfamiliar with the habits of this fish, it will appear quite paradoxical, that such a sluggish fish should be able to live upon such active crustaceans. But it can be explained. If anyone exanines the montli of one of these, he will find that the brown stripes of the head and 
boriy are continued right into the mouth on to the palate and the top of the tongue. The result is that the mouth might be wide open and no one-not even a little Shrimp at close quarters-could tell that it was. Now, growing on the end of the snout, and immediately over the centre of the mouth, is a thin but stiff filament, about $3 / 4$ to I inch in length. forming a fishing-rod: and, on the end of this little rod, is a soft, fleshy appendage, which is the bait. This appendage is divided at its extremity into several soft, short filaments, so as-no doubt-to give a rough general resemblance to some small marine animal. When the little Angler feels that it is hungry, all that it has to do is to rest amongst the weed, open its mouth, wag its little fishing-rod and bait about, and one or other of the little Shrimps, which are very plentiful in these localities, will be sure to come after the tempting morsel, probably cven standing right on the brink of the little tyrant's month in the act. Comparatively-large Shrimps are swallowed whole by the Anglers without being in any way mutilated.

Nothing is known in regard to the breeding habits of any of our Angler-Fishes, but one species which dwells upon the floating "Gulf-weed" makes a wonderful nest, suspended by means of silk-like fibres, which prove strong enough to support the huge bunches of eggs, that hang like grape-clusters within its orbicular case. Each nest is made of one seaweed: the different "twigs" being brought together and made fast to each other by the fish, by means of a pasty sort of substance provided hy the animal itself.

The species of Angler-Fish here illustrated (Fig. 77), is one of our less common kinds.

\section{THE LEATHERJACKETS OR FILEFISHES.}

(Family: Balistida.)

M.NY kinds of Leatherjackets swarm in Australian seas. They are the bété noire of both amateur and professional fishermen: and, of the latter, perhaps the Crayfishermen are the greatest sufferers from their depredations; as they 
get into the Crayfish-pots and eat the bait. Several of the species attain to a large or fairly-large size, and are of some economic importance. They may all be recogniserl at once as Leatherjackets by even the most casual observer. oil account of the rough leathery skin and the sharp, often higin, serrated and barbed spine behind the head on the back. In size, our Leatherjackets range from the wee little green fellow of little more than an inch or two (Monacanthus trossulus) up to the common large yellow one sometimes known as "Chinaman" which attains to a length of upwarks of two feet (Monacanthus ayraudi). The barbedspine (just mentioned), at the back of the head, is really the remmant of the first dorsal fin which in fishes of a closely-allied genus, Balistcs, still exists. It is from the barbed and serrated nature of this spine, that they have received the name of File-Fishes. The tough skin covered over with the exceedingly rough and small scales is responsible for the other name of "Leatherjackets," by which they are most familiar to us. In these fishes both jaws are armed with eight strong, incisor-like teeth, and with these they are able to crush up very hard substances, such as the shells of Mollusks and Crabs, etc. Some of them are at times very destructive to young edible Orsters. Their rough scutes or scales are so small as to give to the skin quite a velvety appearance. Some of these scales are mushroom-shaped and others are spinous. 'They all make most interesting objects for the microscope. The term "scales" is here really not quite correct as they are more properly described as "dermal papillæ." Some of the species possess a peculiar armature on each side of the tail, that of the male being usually different to what is found on the female. This armature may consist either of simple spines arranged in rows, or of the development of the minute spines of some of the scales on each side of the tail, into long, stiff bristles; so that a patch is formed, which looks very much like a tooth-brush. Both of these different forms of armature are to be found in well-known Australian species.

As it will be quite impossible within the scope of such a general little work as this, to even casually mention eren 
a few of our many species of Australian Leatherjackets, I will have to content myself with two well-known forms; namely, the "Orange-spotted Leatherjacket" (Monacanthus hippocrepis) and the "Yellow Leatherjacket" Monacanthus ayraudi).

The Orange-spotted Leatherjacket is a large and handsome species, which occasionally finds it way into the fish markets at Sydney (at least). It is essentially an "outside" fish and is taken at times by line-fishermen in the vicinity of reefs and rocky shores. The species is very widely-distributed in Australia; as, in addition to its occurrence on the coast of New South Wales, it is known to be an inhabitant of the waters of Victoria. South Australia, Tasmania and Western Australia; though at the same time practically nothing is known as to its relative abundance in those waters. It may very properly be regarded as one of our food-fishes, as its flesh is of good flavour and it attains

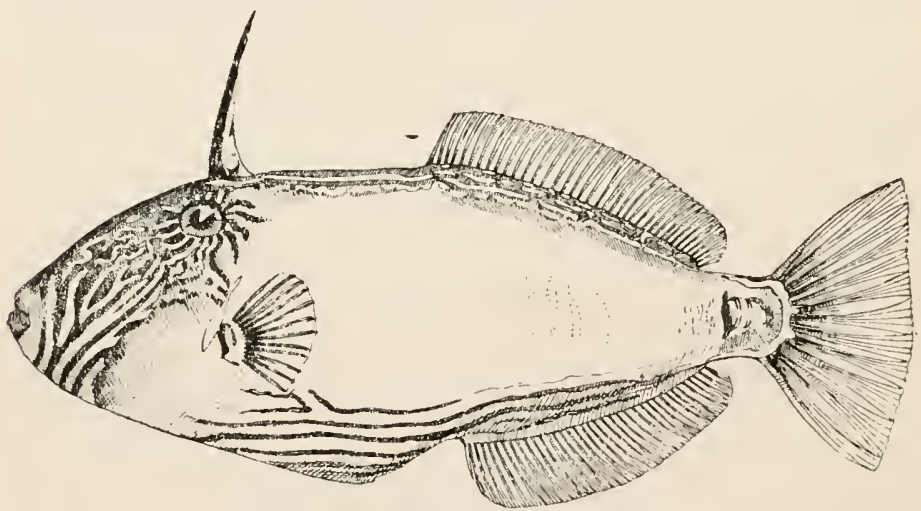

Fig. 78.-ORANGE-SPOTTEO LEATHERJACKET

(Monacanthus hippocrepis).

to a length of over I 8 inches. When alive it possesses the most lovely tints, the upper or dorsal surface being of an olive-green or vellowish-green and shading into a lighter tint below. On the middle of each side is a large, irregular blotch, of a bright orange-colour, within which, a horseshoeshaped band is sometimes present. The lips are surrounded by two or three dull, blue, yellow-edged bands, and the sides of the abdomen, with narrow waving bands of an intense 
blue. Even the most prosaic person, on viewing this splendid-looking fish, must be filled with admiration. The scales are rough yet velvety, and upon each side of the tail peduncle are three pairs of very strong curved spines.

The Yellow Leatherjacket is a very commion fish on the coast of New South Wales, and, like the one just mentioned, in its adult state is principally taken by line on the outside reefs, by fishermen engaged in fishing for Snapper. At times vast shoals occur, and upon such occasions, fishing with the hope of capturing anything else is altogether out of the quiestion. In many instances, where it is itseli hooked, its powerful and sharp teeth enable it to cut the line with the greatest of ease. Occasionally numbers of them are brought to market and sold. The demand for them is gradually increasing, and it will still further increase as their good esculent properties become better known. As with all the Leatherjackets it is better to skin these fishes before cooking. This is quite a simple matter, as the tough skin is very readily pulled off the body.

The colour of this species is usually a uniform yellow or yellowish-brown in the adult: while the young have a ground colour of yellow, upon which are several dark longitudinal stripes rumning from the head to the tail. The young are exceedingly common sometimes, near the entrances to some of the bays and estuaries of New South Wales: and. with several other species of Leatherjackets, are taken by the fishermen in swarms. The net-fishermen of course, have a great detestation of these pests; not only because of their uselessiess to them, but because they become entangled in the meshes of the net by the dorsal spine, and then it is a labour to extricate them. They are usually thrown up on the beach to die. The Yellow Leatherjacket reaches a length of about two feet.

A curious-looking Australian Leatherjacket which possesses on each side of the tail, those peculiar tooth-brush-like areas before mentioned is known as Monacanthus guntheri. 


\section{BOX-FISHES OR TRUNK-FISHES.}

(Family: Ostraciontido.)

Tur remarkable fishes which form this family are totally unlike any that we have so far discussed; as, in these, the skin of the body forms a hard, continuous carapace, consisting of hexagonal plates laid together like a mosaic pavement. The only portions of the skin that are not hardened are those immediately around the month, tail, and fins, so as to enable these to lave a free movement.

Several interesting Box-Fishes inhabit our waters. One of these is the Linked Box-Fish (Lactophry's concatcnatus). 'This is a funny-looking little fellow with a three-sided body and a most severe-looking little face. It is of a deep-greenish colour, and is nsually of small size. It is not uncommon on parts of the New South Wales coast, being obtainable in small numbers at all times on the bottom off Vatucluse, in Port Jackson.

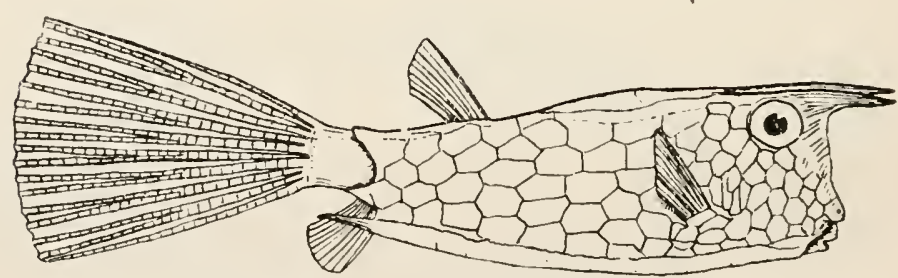

Fig. 79.- - Horned Box-Fisir (Ostracion comutum).

Another one of these curious and quaint-looking creatures is the Horned Box-Fish (Ostracion comutum). This attains to a length of about I5 inches, and has a four-sided carapace, with two long spines, like horns, jutting straight out from the top of the head, and two more of about equal length below the tail. (This is the species in our illustration.) It occurs also in India.

Other kinds also are found in our seas; principal among which is the Lenticular Box-Fish 'Aracana lenticularis). 


\section{THE TOAD-FISHES}

(Family: Tetrodontida.)

THE most familiar example of this family, to most of my readers, is that plump little spotted fish, to be seen usually near the top of the water. swimming around the rocks near sandy localities. This is the Toado (Tetrodon hamiltoni), which reaches a length of 4 to 5 inches. It is sometimes caught on the small-boy's line with a "fly-hook" and often comes within the scope of the fisherman's hauling-net.

All Toad-Fishes have the power of inflating their bodies, puffing them out often to a prodigious extent, until they appear like footballs. Our little Toado possesses this habit and it is known to many of our boys; who, I am sorry to say, often indulge in the rather cruel "sport" of rolling the little fish on the sand to make it puff itself out; and when it has done this, of jumping on it suddenly; bursting it with a loud report.

There are many kinds of these Toad-Fishes in our seas, some of which reach a length of more than 2 feet. Most of them have small sharp spines set in to the thick fleshy skin, and when the body is inflated, these spines are erected. Some species have these spines only on the back, some only on the abdomen and many have them on both back and abdomen.

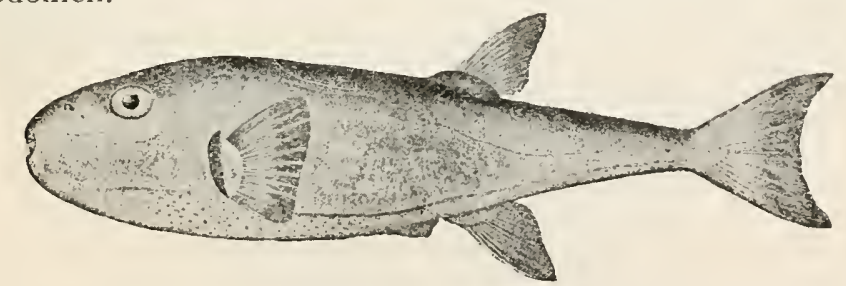

Fig. 80.-ToAd-Fisir ('Tetrolon lavigatus).

None of the Toad-Fishes are of use as food and some of them are poisonous. Occasionally, certain kinds appear on our coast in enormous shoals. At such times the water over a large area and for several days appears to be nothing but a living mass of Toad-Fishes. Such a visitation occurred off the coast of New South Wales a few years ago. 
The teeth, in these fishes, are welded together to form two powerful crushing plates in each jaw. From that character the generic name of Tetrodon (which includes a large number of Toad-Fishes), meaning "four-teeth," is derived.

The Toad-Fish illustrated (Tetrodon lavigatus) is a very widely distributed species.

In America the fishes of this family are often termed "Rabbit-Fishes" on account of their peculiar teeth, and also -occasionally-the rabbit-like head.

\section{SEA-PORCUPINES.}

\section{(Family: Diodontide.)}

THE Porcupine-Fishes are somewhat similar in many ways to those just mentioned, but they are generally characterised by the presence all over the skin of long and sharp thorns or spines. In some species, such as our common "Porcupine" (Dicotylichthys punctulatus) these spines are im-

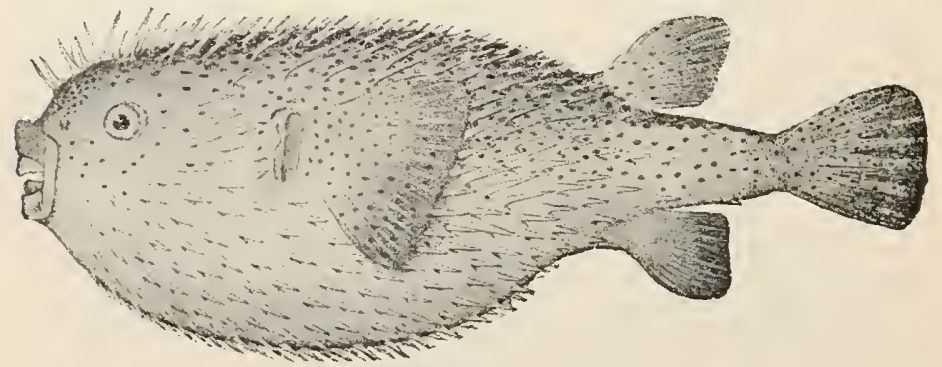

Fig. 81.-Sea-Hedgehog (Diodon hystrix).

moveable and jut out from bony plates which are set in the skin of the fish; while in the others, the spines are erectile; that means that when the fish is not feeling particularly warlike, the spines lie against the body pointing backwards; but immediately the skin is inflated with either air or water the spines stand straight out all round the fish, making it a really formidable object. Some Porcupine-Fishes are 
able to erect the spines about the head at will by means of muscles lying under the skin. Their teeth are welded into the one massive crushing plate in each jaw.

Some of these attain to a length of about 2 feet. They are very destructive to young Oysters.

All these fishes have a very bad reputation; indeed some of them are highly-poisonous and are said to have caused long-continued illness and death. In some cases the poisonous properties seem to be more powerful at one time of the year than another.

The species illustrated is Diodon hystrix-sometimes known as the Sea-Hedgehog.

\section{THE SUN-FISHES.}

(Family: Molider.)

THE Sun-Fishes are sea-rovers and are very rarely taken in the harbours. They are found in all oceans within tropical and temperate zones. They possess a most curious disc-

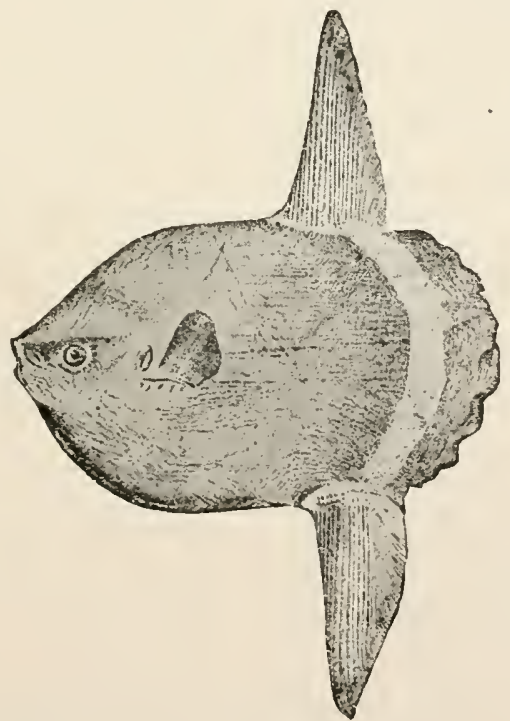

Fig. 8’.-DUN-Fisir (Mola mola). 
shaped body and pass through a number of remarkable changes with age, the young being quite unlike the adult. The former has large, strong spines upon its body, while the latter is quite smooth. Their jaws are undivided in the middle, comparatively feeble, but well adapted for masticating their food, which consists of small pelagic crustaceans, jellyfishes and larval fishes. The Common Sun-Fish (Mola mola), which has been taken on the coast of New South Wales and other portions of the Australian coast, attains to a very large size, measuring not far short of ten feet and weighing 1800 pounds. It has been observed to swim slowly about near the surface, the high dorsal fin above the water.

\section{LUNG-FISHES.}

(Sub-class: DIPNEUSTI or DIPNOI.)

BEFORE passing on to take a cursory glance at the Sharks and Rays, I feel it incumbent upon me to dwell for a little upon the highly-interesting Lung-Fishes. These have earned the common name here applied to them, because of the curious fact that the air-bladder is transformed into a simple kind of lung; so that we here find in these fishes. rather wonderful beings that are able to breathe either water or air. A peculiarity of external structure is that their paired fins give one the impression of being more like simple limbs than fins.

Lung-Fishes come of a very ancient stock; fishes related to those at present existing, having lived in some of the waters of the earth even as far back as palæozoic times. The existing kinds are referred to three genera; known respectively as Neoceratodus, Lepidosiren and Protopterus; representing three distinct families, the first being found in Australia (Queensland), the second in South America, and the third in Africa.

'Though all of the species belonging to these three genera agree with one another in some general characters, they differ very considerably in detail; but I must here con- 
tent myself with a few remarks upon that one which more directly concerns us; I refer to the Australian Lung-Fisl (Neoceratodus forsteri). This fish is a native of the Mary and Burnett Rivers in Queensland; to which it appears to be at present restricted. That it was not always forced to occupy such a small area, is evidenced by the fact that teeth of the same species have been discovered in the alluvial deposits on the Darling Downs in Queensland (these deposits being of later Tertiary age). By many Queenslanders this species is known as "Barramundi," a name which applies with more propriety to Sclcropages (page 25). Other names are "Flathead" and "Burnett Salmon" or "Mary-River Salmon"; the last two on account of the Salmon-like tint of the flesh. By many it is considered to be a good edible fish.

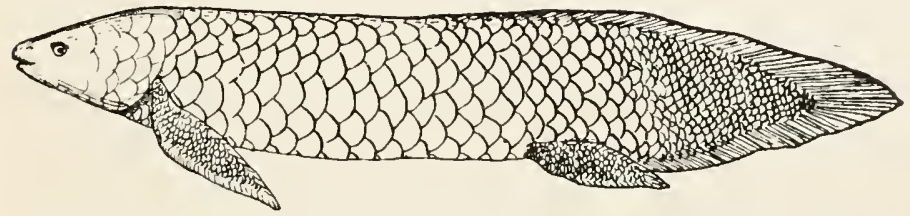

Fig. S:̈.-Australian Lung-Fish (Neoceratodus forsteri).

The Australian Lung-Fish is an inactive, sluggish fish, frequenting the bottom in muddy parts and among weeds. It subsists largely upon crustaceans, worms, and mollusks and to obtain them it is stated to cram its stomach with a great quantity of the leaves of water-plants, when in a decomposing condition; in much the same manner as certain of the "Sea-Cucumbers" (Holothuria), swallow great quantities of sand, so as to obtain from amongst it whatever nourishment it may contain. Under natural conditions it rises to the surface occasionally to fill its lung with fresh air; being able to breathe also in the water itself-unless it be too foul-by means of its well-developed gills.

Though no doubt many people have been and are familiar with this curious fish in its native haunts, not very much of importance has been written; great credit, therefore, must be given to Professor Semon, who, a few year's ago, visited Queensland and investigated to some extent its 
early life-history and habits. The egg is a fairly-large one, measuring more than half an inch in length. The early developmental stages show a general resemblance to those of some of the Amphibians (Frogs, Newts, etc.).

This species is possessed of very large body-scales, some of these often measuring more than 4 inches across.

It grows to a length of several feet.

The discovery of the Australian Lung-Fish in 1870 created the highest interest in the Old World, mainly because of the general similarity of its teeth to some very singular ones which were found in a fossil state in certain geological formations of Europe, India and America. "These teeth, of which there is a great variety with regard to general shape and size, are sometimes two inches long, much longer than broad, depressed, with a flat or slightly undulated, always punctated crown, with one margin convex, and with from three to seven prongs projecting on the opposite margin."-(Günther.) 
Chapter XII.

Sharks and Rays-Lampreys and Hag-Fishes-The LampreysThe Lancelets.

\section{SHARKS AND RAYS.}

\section{(Sub-class: ELASMOBRANCHII.)}

IN both their living and extinct forms, the Sharks and Rays are remarkable, in that they do not possess a bony skeleton, such as that possessed by all the fishes with which we have so far been dealing. Instead, we find that it is wholly cartilaginous or partly calcified (that is, hardened by the addition of calcareous or limey matter), while the skin takes the form of a more or less uniform coating of dermal denticles, which under the microscope show a structure similar to that of teeth. If these denticles are small, pointed and close-set, the skin is called "shagreen." In some cases large tubercles, plates or spines of various sizes, are found to be developed.

The Elasmobranchs-as the Sharks and Rays are called-are chiefly active predaceous fishes, occurring in nearly every sea of the world, and also in many freshwaters; even in some cases living entirely in the latter. As compared with other fishes, none of them are very small; while some of them are exceedingly large, and amongst the Sharks are included the largest of all living fishes. In regard to their bathymetrical distribution, it may be mentioned, that they are at present known to occur in depths ranging from the shallowest water, down to nearly ioon fathoms. Though they are most abundant within tropical or semi-tropical areas, they are quite numerous-both as regards species and individuals -in temperate regions, while certain kinds are known to inhabit permanently, waters lying within the Arctic and Antarctic Circles.

So far as is at present known, all Elasmobranchs are 
carnivorous; their diet ranging from (occasionally) Man himself, down to Crustaceans and Sea-Urchins.

The great majority of these fishes are viviparous (that is, the young are brought forth alive) ; the remainder being oviparous (that is, the young are hatched out after the deposition of the egg). Only one of the very large Sharks is known to be oviparous and that is the huge Greenland Shark (Lemargus borcalis), which is unique among Sharks, in that it produces eggs without any horny covering; these being deposited on the sea-bottom and left there to hatch. The other oviparous Sharks are the small species known as Dog-Fishes, the small Cat-Sharks and also those curious and-to Australians_familiar "Bullhead" or Port Jackson Sharks. The Rays that are oviparous, are those helonging to the family Raiida, popularly known as "Skates."

Many of the Sharks and even a few of the Raysmore particularly the former-are exceedingly formidable, and are greatly feared in many parts of the world.

Fossil remains of Elasmobranchs of many species, are very abundant in some geological formations. These often take the shape of fin-spines and dermal-plates. The former are usually known as "ichthyodorulites."

Elasmobranchs are considered to be of a very primitive type among fishes, and amongst their number we must look for the ancestors of the higher bony-fishes or teleosteans.

Many species of Sharks and Rays, of many families, are known to inhabit the waters of our Australian coastline and they include amongst their numbers, some of the most ferocious "tigers of the deep."

Amongst the Sharks may be mentioned: The Sevengilled Shark (Notorhynchus indicus), the Port Jackson Shark (Heterodontus philippi), the Crested Port Jackson Shark (Heterodontus galeatus), the Wobbegong or Carpet Shark (Orectolobus barbatus), the Tiger Shark (Galeocerdo rayneri), the Blue Shark* (Prionace glanca), the "Whaler," sometimes known as "River" Shark (Carcharias brachyurus), the Hammer-headed Shark (Sphyrna sy'gena), the Fox-Shark or Thresher (Alopias z'ulpes), the

\footnotetext{
* Not tre Lilue l'ointer.
} 
Grey-Nurse (Odontaspis taurus), the Blue Pointer (Lamna glanca), the White Pointer (Carcharodon carcharias), the Basking Shark (Cetorlimus maximus), the Little Saw Shark (Pristiophorus cirratus), the great Sawfish (Pristis zysron), the Angel Shark or Monkfish (Squatina squatina), and the Ghost Shark (Chimera ogillbyi): while amongst the Rays the following are of interest: The "Shovelnose" (Rhinobatus banksii), the

Fiddler" (Trygonorrhina fasciata), three species of true Skate (Raia), the Numb-Fish (Hypnos subuigrum), the Common Stingray (Trygonoptera testacea), the Giant Stingray (Trygonoptera bucculenta), the fearsome Thorn tailed Stingray also known as "Black" Stingray (Dasyatis thetidis), the Sephen Stingray (Dasyatis sephen), the Spotted Eagle Ray (Aëtobatis narinari), the Eagle Ray (Nyliobatis australis) and the immense Prince Alfred's Ray (Manta alfredi).

As it is not desirable here to go into any great detail regarding these Sharks and Rays, a few of the more important or striking may be selected from among them.

The Seven-gilled Shark: This is a widely-distributed species, occurring in the Seas of India, Japan, South Africa and California, as well as in our own seas, where it is not very common. In Australian waters it is not looked upon as one of the dangerous species, usually not attaining a very large size. Its common name is derived from its possession of seven gills, and, correspondingly, scven gill-slits in place of five; which is the usual number for elasmobranchiate fishes. In addition to this character, it may be at once distinguished, by its possessing only one dorsal fin-. and that far back on the body, opposite the anal-in place of two, as ordinarily seen. From this feature it is often known as the "One-finned Shark."

In this species, the teeth are of a very peculiar shape, most of them having a comb-like cutting edge.

The Port Jackson Shark This is a small species attaining a length of about 5 feet, more frequently seen of a length of about 3 feet. It has a high, squarish head, this being a character of the fishes of the genus Hetcrodontus generally. 
The jaws and teeth are of a very striking nature, as will be seen from the accompanying illustration, while the large oval egg-cases with their spiral outer covering ending in long tendrils, are, perhaps, amongst the most striking of Nature's works.

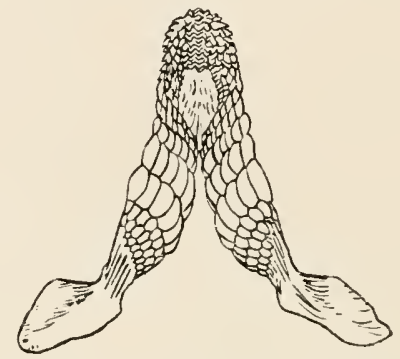

Hig. 84.--Teeth of PorT JaCkson SHaRK (Heterodontus philippi).

The four or five species of these "Bullheads" at present existing are the only surviving representatives of a family of Sharks, shewing very ancient primeval characters, and which are numerously represented in certain geological formations. The fossil forms far exceeded in size all of the existing species.

The dentition is adapted for the mastication of hardshelled crustaceans, mollusks, and echinoderms, upon which (particularly the last-mentioned) they principally subsist.

The Port Jackson Shark is very abundant in Port Jackson and along a great part of the Australian coast, being found also in New Zealand.

The Wobbegong: This hideous-mouthed creature attains a large size; individuals of to feet in length being not uncommon. It is often called Carpet-Shark, on account of the beautiful carpet-like pattern displayed over the skin. This colouration, coupled with the presence of peculiar skinny, weed-like appendages on the head and round the mouth, give it a most-decided resemblance to its surroundings. And this is necessary, as this fish is not of a roving disposition, but lies quietly amongst the weeds and rocks, calmly waiting for some "food" to come by. It is described by fishermen as an "ugly-looking brute" and certainly it has a most horrific aspect. 
Its teeth are long, sharp and awl-like.

The Tiger Shark: This powerful and dangerous Shark, roams the oceans freely from India, to Australia. During the summer season, large numbers abound on the eastern coast of Australia, where they enter the bays and larbours, "seeking whom they may devour." Every year a good many are captured in the lower waters of Port Jackson. The largest specimen captured on the coast of New South Wales that has come under my notice, measured I3 feet 6 inches; but a length of 16 feet (or even more) is not unknown.

In this species the serrated teeth are oblique, have one large pointed cusp, and have a deep notch in one side.

The Fox-Shark: This species is very widely-distributed, being found pretty generally throughout the temperate and tropical seas of both hemispheres. It is quite common in Australian seas, keeping to the open coastal waters. It attains a length of about 15 feet; of which the long, blade-like tail, forms nearly one half. It is not known to be dangerous to Man. Though it is often seen to be attacking Whales and other large cetaceans, it feeds principally upon the smaller teleostean fishes. When feeding, it is said to swim round and round in gradually diminishing circles, splashing the water with its tail, and keeping its prospective victims so crowded together, that they form an easy prey.

The Grey-Nurse: This is a very formidable Shark, attaining a large size and occurring in many waters. At times these "wolves of the sea" rove along the eastern shores of Australia at least, in thousands; freely entering the harbours.

The teeth are long, sharp and awl-like, with a small cusp on each side at the base.

T'he Basking Shark: This Shark attains huge dimensions and is one of the largest fishes existing, reaching a length of 40 feet.

In this species, the teeth are small, very numerous and ronical in shape, without serrations. The five gill-slits on each side are of great length.

It subsists upon small fishes, crustaceans, and other 
small animals, which it obtains near the surface of the ocean; these being strained from the water through the long slender gill-rakers, with which the gill-arches are provided.

Further information in regard to this species will be found under the heading of "Fish Economics."

The Little Saw-Shark: This is a small species, having a somewhat-flattened body, and attaining a length of about 4 feet. It is common in Port Jackson, and is distributed over a great part of our coastline. The snout is long and flattened, and is armed very heavily with teeth of unequal length. Many of these teeth are very large and acute and between them are smaller ones. Beneath the snout are two tentacles. The last character alone would be quite sufficient to enable even the tyro to distinguish between this species and the young of the larger "Sawfish"; as in the latter, there are none of these tentacles.

The Little Saw-Shark is naturally a bottom-hunting fish.

The Sawfish: This is a monster of terrible aspect. With a "saw" of, often, 5 feet or more in length, it grows to a size of at least 20 fect.

Widely distributed, it roams the seas in search of food, commonly occurring in the bays and mouths of rivers, during the summer-time, along the coasts of northern New South Wales and Queensland.

The snout is armed with strong acute teeth, and with this weapon, it is able to inflict tremendous havoc amongst shoals of fishes, throwing the "saw" from side to side wilh immense force.

This species is often miscalled "Sword-fish," a name which belongs properly to certain teleostean fishes of the family Histiophorida, previously mentioned.

The Angel Shark: This strange-looking creature abounds in most temperate and tropical seas: being fairly common on parts of the Australian coast, where it attains a length of about 5 feet. In form, it approaches somewhat, the Rays, being broad and flattened. It is viviparous, producing about twenty young at a birth, these being about 9 or to inches in length. 
This species occurs fairly abundantly in the Mediterranean Sea, where it is known to the French fishermen as "Squale Ange" and to the Italians as "Angelo." From this it will be quite apparent, that the fancied resemblance to an "Angel" is very widespread.

The colours of this fish are so arranged, as to exactly assimilate it to the sandy surroundings, upon which it is usually found on our coast. A fine specimen which I recently handled, was of a beautiful creamy sand colour, speckled all over with a very light fawny-brown, with the exception of larger and smaller ocellations here and there. which were of the cream ground colour. Even the borders of the eyes themselves (the irides) were speckled in the same manner, the pupil being a narrow black slit. This example measured 3 feet 5 inches, and was captured in Port Jackson. After capture, it gave birth to a number of young, which were perfectly formed, and were about Io inches long. They were of a still lighter tint than the parent.

The Numb-Fish: This species is usually known to the fishermen of New South Wales as "Nummy," from its power of temporarily benumbing parts of the human body with which it comes in contact, through the sudden delivery of sharp electric shocks.

It is very flat and thick, with a rounded margin, the tail being very short.

It is common along the coast of New South Wales, attaining a length of nearly 3 feet.

On each side of the head, is an apparatus for the generation of electricity; and large fishes are able to give quite a powerful shock.

Other names for this and an allied species (Narcinc) are "Electric Ray," "Torpedo Ray" and "Cramp Fish."

The Common Stingray : This well-known and greatly-abhorred Ray, occurs very commonly along the coast of New South Wales, where it is the bété noire of the fishermen. Though a comparatively small species, growing to about 2 feet in length, it is able to inflict with its sharp, barbed caudal spine the most painful and dangerous wounds, wounds which very often take many months to heal, and 
in some cases, cause permanent disablement. At times these and others of our many Stingrays may be easily captured in thousands. Though no attempt is made at the present time to utilise them, this could easily be profitably done, as the "wings" or pectoral flaps could be converter into gelatine, while much oil could be obtained from the livers, the residue being then turned into a fertiliser, rich in phosphates.

The Thorn-tailed Stingray: This fearsome fish, which attains a weight of between 5 and 6 hundredweight, is, as far as we at present know, only obtained on the coast of New South Wales. Its tail is armed in a most terrible manner. In addition to possessing the long serrated spine, set in the back of the tail, which is so typical of the Stingrays in general, it has, all over the skin of the tail, calcareous plates varying from an inch or more in diameter, down to the smallest of asperities. Each of these dermal plates, has in its centre a short, stout and acute spine. The caudal-spine or "sting" itself, sometimes reaches a length of 15 inches (occasionally there are two or three).

The tail being long, muscular, powerful and lithe, it can better be imagined than described, what fearful destruction could be wrought by it, and it is well for our surfbathers, that the Thorn-tailed Stingray (known also as "Black Stingray") is not abundant in the shallower waters. The tail is sometimes 6 feet in length.

Prince Alfred's Ray: This is the name given to a huge Ray which is sometimes taken on the coast of New South Wales. One specimen captured in 1868 at Manly Beach, Port Jackson, measured I I feet in breadth.

In this Ray, the head is free from the pectoral flaps, is truncated in front, and possesses on each side, a horn-like appendage pointing forward and inward. 'The mouth is in front (not beneath as is usual amongst the Rays) and is very wide.

The specific name of alfredi was given this species in honour of the King's brother, the late Prince Alfred. 


\section{LAMPREYS AND HAG-FISHES.}

(Class: CYCLOSTOMATA.)

THE Cyclostomata are often called the "Marsipobranchii," in reference to their pouch-like gill-clefts. They are divided into two orders; the first of which is that including the HagFishes or Borers, which are chiefly parasitic upon teleostean fishes, while the second is made up of the Lampreys.

\section{THE LAMPRFYS.}

(Order: PETROMYZONTES.)

THE Lampreys are curious Eel-shaped animals, having a large suctorial disk leading behind and above, into the mouth. Numerous horny teeth are situated on the inner surface of the sucker, as well as on the tongue. They all belong to the one family, known as the Petromyzontide, and are distributed over the greater part of the world. They are chiefly marine, some to a greater extent than others; but in those species the life history of which has been closely investigated, it has been found that they ascend the

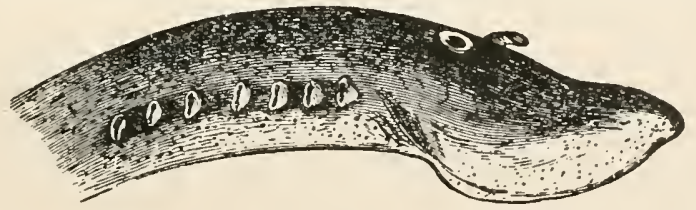

Fig. 85.--Short-hended Lamprey (Mordacia mordax).

rivers for spawning purposes. They are all carnivorous, obtaining their food by attaching themselves by means of their sucking disk to various fishes, and then rasping the flesh away with the lingual (tongue) teeth. In Europe and America, large numbers of fishes are known to be destroyed by Lampreys every year.

There are two species of Lamprey in Australian waters; 
the Short-headed Lamprey (Mordacia mordax) and the Wide-mouthed Lamprey (Geotria australis). Little is known of their habits.

\section{THE LANCELETS.}

(Group: CEPHALOCHORDATA.)

THE Lancelets, usually known under the name of "Amphioxus," form a small group of little fish-like forms, in which there is no skull and no vertebral column. They are not true fishes, though as they are usually grouped with them, they are deserving of mention here. They are slender, transparent or semi-transparent animals of 2 or 3 inches in length, pointed at both ends, frequenting shallow coastal waters and burrowing into the sand with great rapidity.

Three species of Lancelet are found on the coast of Australia; these being Branchiostoma bassanum, B. belcheri and B. cultellum. The first is a native of New South Wales and Victorian waters, while the others have been taken from the coast of Queensland.

The Lancelets are all included in one family; that known as the Branchiostomatida. 


\section{FISHING NETS OF NEW SOUTH WALES. 24I}

\section{Chapter XiII.}

Fishing Nets of New South Wales.-Hauling-Net, Garfish-Net, Meshing-Net, Gill-Net, Trammel-Net, Drum-Net, Trawl-Nets.

Fish Economics. - Fish Oil, Fish Fertilizer, Skins of Fishes, Scales of Fishes, Guanin.-Food Value of Australian Fishes compared with Lean Beef.

\section{A DESCRIPTION OF THE FISHING NETS IN USE IN THE WATERS OF NEW SOUTH WALES.}

IN dealing with the Murray Cod, slight mention was made of some of the gear used in its capture; and before closing this little volume, it may be as well to briefly describe the various kinds of fishing-nets used by the fishermen of New South Wales; especially as several of them have been mentioned here and there. As befits her station, as the Mother State, New South Wales has developed her fisheries, to a very much greater extent than has any other State of the Commonwealth. Though this is quite true, and though the New South Wales fisheries are even at the present time of very great importance; still, comparatively speaking, we are only "on the threshold"; and there are vast storehouses filled with untold wealth lying at our doors, with their portals wide open, bidding us to enter and carry off the spoil.

As deep-sea fishing-other than "hand-lining"-is not carried on to any great extent in the waters of New South Wales (or, indeed, in any of the Australian States), it naturally follows that the fishing-nets have been chiefly adapted for use in shallow waters, and principally belong to the group known in a general way as "Hauling-Nets." In these, there is usually a central portion made up from netting of a smaller mesh, this being termed the "bunt"; while the end pieces are called the "wings." Not infrequently the central portion of the bunt itself is made very much deeper (that is, it contains more meshes) than the neighbouring parts; with the result that when the net is 
hauled, a kind of "bag," or "pocket," is formed. Other very important nets are the Meshing-Nets (a small kind of which is known in the waters of the Murray River system as the "Gill-Net") : while the Trammel-Net is also used. The Trawl-Net, which plays such an important part in the capture of the principal edible fishes of Great Britain and many other countries, has, so far, been used here, only in an experimental manner.

Briefly stated, the various kinds of our nets are as follows:-The General Bauling-Net or Mullet-Net (two kinds), the Garfish-Net, the Prawn-Net, the MeshingNet, the Gill-Net or small Meshing-Net (for use in fresh-waters), the Trammel-Net, and the Drum-Net (for use in fresh-waters).

The General Hauling-Net.-Two kinds of this net are used on the coast of New South Wales; one being allowed for use in the coastal "lakes" only, while the other may be used in other coastal waters. The following are the dimensions, * as set out by law, of the former:-

Total length of net not exceeding four hundred fathoms. $†$

Length of bunt not exceeding one hundred and thirty-four fathoms.

Mesh of bunt not less than two and a quarter inches.

Depth of bunt not exceeding two hundred and fifty meshes.

Length of each wing not exceeding one hundred and thirtythree fathoms.

Mesh of wing not less than three inclies.

Depth of each wing not exceeding one hundred and fifty meshes.

Hauling line at each end of net not exceeding two hundred and fifty fathoms in length.

* All the dimensions of fishing-nets given here, are in accord with the regulations of the New South Wales Department of Fisheries in existence at the time of writing (March, 1906). There is always a possibility of slight alterations being made from time to time, or of additional nots being legalised.

+ A fathom is equal to a length of 6 feet. 


\section{FISHING NETS OF NETW SOUTII I'ALES. 243}

The dimensions of the second, and smaller. HaulingNet, for use in the harbours and estuaries, are as follows:-

Total length of net not exceeding two hundred fathoms.

Length of bunt not more than one-third of total length of net.

Mesh of bunt not less than two and a quarter inches.

Deptli of bunt not exceeding two hundred and fifty meshes.

Length of each wing not exceeding one-third of total length of net.

Mesh of wing not less than three inches.

Depth of each wing not more than two hundred meshes.

Hauling line at each end of net not exceeding fifty fathoms in length.

Both of these nets are for use in the capture of all marine fishes excepting Garfishes.

The Garfish Net.-This is intended for use in the capture of the Garfishes only, and is as follows:-

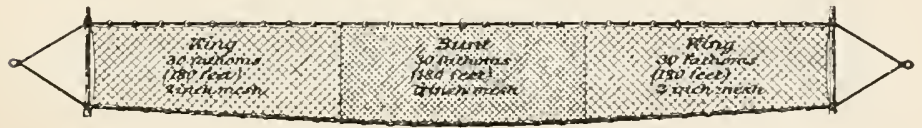

Fig 86. - 'ARFISH OR "BALLOO" NET.

Total length of net not exceeding one hundred and fifty fathoms.

Length of bunt not more than one-third of the total length of net.

Mesh of bunt not less than one inch and one-eighth of an inch.

Depth of bunt not exceeding two hundred and fifty meshes.

Length of each wing not exceeding one-third of the total length of net.

Mesh of wing not less than two inches. 
Depth of each wing not more than one hundred meshes.

Hauling line at each end of net not exceeding one hundred fathoms in length.

The accompanying illustration of a Garfish-Net of 9 ? fathoms in length will give the reader some idea of the construction of "Hauling-Nets" in general. In this instance, there is scarcely any bag in the bunt.

The Prawn-Net--As its name implies, this is intended solely for the capture of the valuable Prawns which are so abundant along the coast of New South Wales. As usually made use of, it is what is termed a "Sunken-Net"; that is, it is so heavily-leaded, that it sinks to the bottom; the corks along the "cork-line" buoying it in a vertical position, in the water. There is usually a fairly large "bag" in the bunt.

Two sizes of Praw1-Net are allowed to be used in certain restricted waters. The principal one is as follows:Total length of net not exceeding twenty fathoms.

Mesh of net not less than one inch.

Depth of net at commencement of gorings not exceeding two hundred and fifty meshes.

Greatest depth of net in centre of bunt not exceeding three hundred and fifty meshes.

Distance from goring to goring along the lines not exceeding four fathoms.

Hauling lines at each end of net not exceeding seventy fathoms.

This net is for use in all localities other than closed waters, and the few in which the smaller Prawn-Net may be used. The latter is described as follows:-

Total length of net not exceeding fifteen fathoms.

Mesh of net not less than one inch.

Depth of net not exceeding two hundred and fifty meshes. Hauling line at each end of net not exceeding thirty-five fathoms. 


\section{FISHING NETS OF NEW SOUTH WALES. 245}

The Meshing-Net. * - In use, this is a fixed (or set) net; arranged in such a way that the fishes will swim against it, entangling themselves, by their gill-covers, in its meshes. During the mullet-season (early Winter), enormous quantities of mature Sea Mullet are captured by means of this net. $\dagger$ Its lawful dimensions are as follows :-

Total length of net not exceeding four hundred fathoms.

Mesh of net not less than three inches.

Depth of net not exceeding one hundred meshes.

In this kind of net there is often no distinct "bunt," the mesh being uniform throughout; in some cases, however, a bunt is formed of three-inch mesh, while the wings are of three-and-a-half-inch or of four-inch. Other modifications are also to be found.

The Gill-Net is greatly used for the capture of fishes used as bait for Murray Cod, and also for Yellow Belly or Golden Perclı and Silver Perch. As will be seen by the following description, it is a very small net:-

Total length of net not exceeding thirty yards (fifteen fathoms).

Mesh of net not less than four inches.

Depth of net not exceeding ten feet.

This net is usually made from very light (fine) twine.

The Trammel-Net.-This form of net is used but little on our coast at present; though, on account of its general effectiveness, a great extension of its use is warranted. Immense numbers of our fishes, many of which cannot be "reached" in other ways, might be captured annually, by a consistent use of the Trammel-Net. As its action in capturing the fishes is but little understood by the average person, the following description, with the accompanying illustration, will, no doubt, prove acceptable.

The Trammel-Net is really a combination of three long nets placed side by side and fastened together at the top, bottom and ends. Each of the outer nets is formed of very

* Usually called " Mashing-Net" by fishermen.

$\dagger$ in addition to those captured with the General Hauling-Net. 
large meshes. These outer nets are so "hung" or mounte 1 that the meshes of both, exactly correspond in position; and a fish might pass through them as if they were a single net. The third net, however, is placed between the other two, and has its meshes quite small; but it is much longer than the outer nets, and usually about twice as deep; consequently, there is a large quantity of slack netting between the two outer nets.

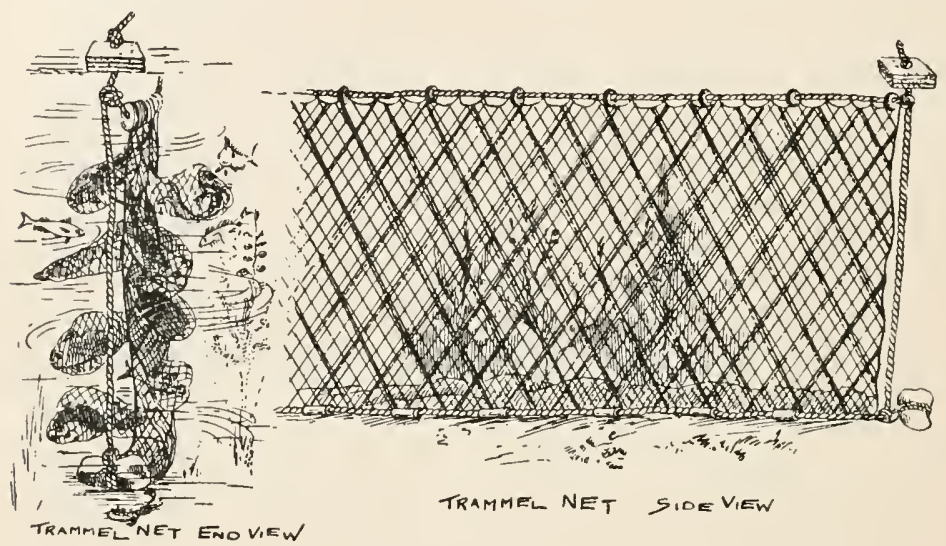

Fig. 87.

When in use, the "Trammel" is set along the bottom; being particularly effective on, or in the vicinity of, rocky headlands or sunken reefs. It is anchored and buoyed at each end, the upper edge, or "back," being well corked, while the bottom, or "foot," is well weighted with lead to keep the whole length of the net close down on to the bottom. so that nothing might pass under. As the outer nets stand with their meshes fully open and exactly opposite each other, and the small-meshed net hangs loosely between them, any fish trying to pass through the first one, meets the second (small-meshed) one and carries a portion of it through the third; thus forming a kind of bag or "pocket." As there is a large-meshed net on either side, the net is equally effective on whichever side the fish approaches it.

The name of "Trammel" is said to be derived from the French tremail or tramail; these being a corruption of trois mailles, signifying "three meshes." 
The lawful Trammel-Net for use in the waters of New South Wales may be described as follows:-

Total length of net not exceeding three hundred fathons.

Mesh of inner net not less than three inclies.

Mesh of the outer net not less than eight inches.

Depth of net not exceeding one hundred meshes of the three-inch mesh.

The Drum-Net-This net is used along the banks of watercourses; more particularly in the Murray River and its tributaries. Briefly stated, the Drum-Net is a large cage or trap having a funnel-shaped entrance. To this trap are attached "wings" of varying length, for the purpose of guiding the fishes to the centre, so that they may enter the place "whence there is no return." This net is made of twine, though numbers of them used to be made of wire-netting. The body portion, or trap proper, is supported by two (or three) hoops, situated about 5 feet apart.

The following is a description of the lawful Drum-net for use in the waters of New South Wales:-

Net to consist of not more than three hoops covered with net, with wings attached, to be made of trinc.

Mesh of net on hoops, not less than four inches.

Diameter of each hoop not to exceed three feet nine inches.

Outer hoops to be not more than five feet apart.

Length of each wing not to exceed eight feet.

Depth of each wing not to exceed three feet nine inches.

Mesh of net on each wing not less than six inches.

In describing these nets, I have given the greatest length and depth, with also the smallest mesh, allowed by law; but many fishermen have their own particular fancies, and certain "grounds" necessitate the use of nets of a construction that would not be very suitable in other places; consequently, a very great diversity in length, depth, length ci hatling lines, size of mesh, and general construction (within the prescribed limits) is constantly to be found. 
Though I have described here only the nets which are used in New South Wales waters, generally speaking, with but slight modifications, the same nets are used in one or other of the remaining States of the Australian Commonwealth.

Though, as stated, the Trawl-Net has only been used experimentally in our Australian waters, there appears to be no sound reason why it should not be used very considerably in a commercial way; a few words, therefore, in regard to the principal points of structure, will, no doubt, be welcome.

Two kinds of Trawl-Net are used: the Beam Trawl and the Otter Trawl.

The Beam Trawl is a triangular, flat, purse-shaped net, having its wide mouth held open by a horizontal wooden spar called the "beam"; this being raised a short distance from the ground by two iron supports or "heads," one at each end. The upper edge of the mouth of the net is fastened to the beam, while the under portion, or lower edge, drags over the ground as the net is hauled along the bottom. The length of the beam varies, of course, with the size of the net, the latter being commonly about twice the length of the former. Beams up to 50 feet in length are used. The net gradually diminishes in width until near the end, where for a short distance it is of uniform width; this portion being known as the "cod," or "purse." It is at the cod end that the fishes which are entrapped in the net are mostly collected; and they are prevented from escaping while the net is in use by the cod being closed by means of a "draw-rope." When the net is hoisted in, the draw-rope is cast off, and the fish fall out on to the deck of the vessel.

Certain constructions in the internal parts of the net, which are made to ensure the retention $o_{*}$ all fishes finding their way into it, as well as the finer details of structure, need not be here described.

The Otter Trawl, although used in practically the same manner as the Beam Trawl, differs from the latter very considerably. The most essential difference is that here the "beam" is entirely done away with, the mouth of 


\section{FISHING NETS OF NEW SOUTH IVALES. 249}

the net being kept open by means of "wings" of netting, at the end of each of which is what is termed an "otter-board." On the action of the latter depends, in a great measure, the proper working of the net. The otter-board is a flat, oblong

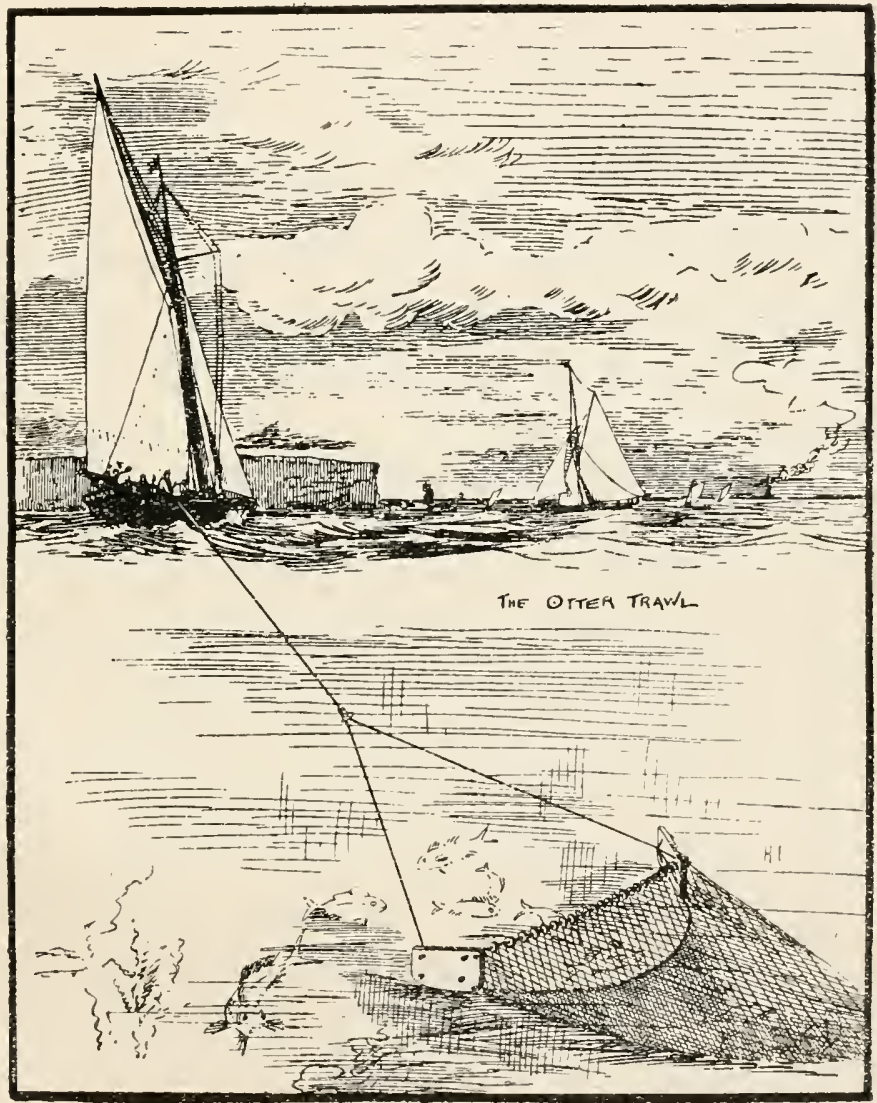

Fig. 88.

piece of stout timber, the height being about half the length. The front lower angle is rounded off so as not to catch the ground when the net is being hauled along, and the whole lower edge of the board is weighted with a heavy iron "shoe," as it is that part which is to be kept at the bottom. 
The accompanying illustration, showing a siriall Otter Trawl being towed along by a yacht, is sufficiently accurate to convey to the reader a very fair idea of what this net is like.

\section{FISH ECONOMICS.}

Much that would be of value and interest to the general reader, might be written here, regarding the thousand-andone preparations, which are composed either wholly or in part, of fish; and which are intended for use as food for Man; but, as the average person must be familiar with many of these (even if not aware of the immensity of the industries concerned with their preparation) I must quickly pass on to deal briefly with some other aspects of "Fish E.conomics."

In addition to their immense importance to Man as food, the uses to which fishes and their products are put are many and various. It is not my purpose to here go into any great detail, either in regard to the processes concerned with the preparation of fish products, or with the products themselves; I merely wish to indicate their very great importance and the magnitude of the industries based upon their utilization and manufacture, as well as to give a little idea of the great variety of the products; hoping thereby to assist in some measure in directing a little attention to the necessity for the better utilization of the wealth that lies within our own waters.

In the preparation on a large scale of fishes and their products for food, there is necessarily a great deal of what would ordinarily be termed "refuse." This includes heads, skins (in some instances), scales, entrails and bones. In most parts of the world this is not thrown aside as it contains much that is valuable. "Formerly nearly all the waste produced in dressing fish for market was thrown away as useless; but in recent years, in the fisheries, as in other industries, the utilization of waste material has been made a subject of careful investigation, and many substances formerly considered refuse, are now found to 
contain elements of commercial value."* The "dressings" at fish markets and fishing centres, the refuse of canneries, dried-fish, smoked-fish and "boneless-fish" factories and even the carcases of whales are turned to account in the production of (I) oil and (2) fertilizing compounds for agricultural purposes.

The most valuable substance obtained from fish refuse, is oil. This is obtained of many kinds and in many qualities. The most familiar-and certainly the most important-is undoubtedly that obtained from the liver of the Codfish (Gadus morrhua) known as "Cod-liver Oil," and which is of very great medicinal value. Though a very large quantity of the oil is produced solely for medicinal purposes, by far the greatest proportion is converted into "curriers oil," while a certain amount is used in the mannfacture of soaps. As showing the great value of this product, it may be mentioned that in Newfoundland alone the total annual output is about I,IOO,OOO gallons, while that of the world is about 3,525 ,ooo gallons; about one-fifth of this being made use of for medicinal purposes.

Not the least important amongst fish-oils are those obtained from the livers of various kinds of Sharks and Rays-principally the former. In many of the species the liver is so large and contains so much oil, that a special fishery is profitably engaged in for their capture. The amount of oil obtained from individual Sharks, varies from about I pint (in the small Sharks known as "Dog-Fishes") up to as much as 400 gallons; the last-mentioned quantity being obtained occasionally from livers of the great Basking Shark, which attains a length of about 40 feet and which is known to occur at times on the coast of New South Wales and Victoria, though not abundantly. As this fish is a denizen of our waters, it will be of interest to give a few particulars regarding its capture on the coast of Peru, where it is fairly common.

Though it is such a large species, not being one or the predaceous kinds, there is no possibility of capturing it by means of a baited hook; consequently, it is necessary for

*Stevenson, Charles: "Aquatic Products in Arts and Industries." Rep. U.S.F.C. for 1902 (1904). 
those seeking it, to approach the animal closely enough to be able to launch a harpoon into it. This is done while it is lying motionless at the surface of the water (a very common habit from which it has received its common name), every endeavour being made to fasten the harpoon in the top of the head, forward of the eyes, the idea being to hold the head up, so as to prevent the fish from going down. When this has been accomplished, the boat approaches, and the Shark is lanced until it is quite dead. It is then taken alongside the vessel, "a hole is cut in one side of the abdomen; a strap inserted on either side of the incision, and the tail hoisted up so as to raise the body somewhat out of the water. A man then enters the abdominal cavity and with a knife, cuts out the liver in pieces. These are passed up on deck, minced, as in the case of whale blubber, and placed in the try-pots. After a sufficient length of time, the cooked liver pieces are removed from the pot, placed in a canvas or hempen bag, suspended from aloft, and permitted to drain. Nothing but the oil is saved. A considerable market for it, exists in South America, where it is used principally as a body for paints for exterior surfaces."*

In deep-sea fishing, as practised in older countries, large numbers of Sharks (particularly the smaller kinds) and Rays are captured, in company with the fishes which are the main objective-such as Herrings, fishes of the Cod family, etc. Though these are quite rightly looked upon as a great nuisance and a hindrance to the various fisheries, still they are not thrown aside: every endeavour being made to "make the best of a bad job"; therefore they are taken ashore to the factories and converted into oil and fertilizer. The number of Sharks so captured, in the Menhaden fishery alone of the United States of America, averages from 7000 to ro,000 ammally. The statement here made will probably come as a surprise to most, and it should completely quieten those amongst us, who decry any attempts at deep-sea fishing-other than trawling-along the coast of, say, New South Wales, "because of the great number of Sharks." 
The world's total annual product of fisl-oil, including that obtained from the livers of fishes of the Cod family, the Herring family, Sharks, Rays and other fishes, as well as that obtained from the refuse before referred to, has been recently calculated to be about $\mathrm{I} 3,000,000$ gallons. And how much of this is made up from Australia? Very little indeed; in fact, quite an infinitesimal proportion. There is no great effort made on any portion of the Ausiralian coast at the present time to utilise, to any great extent, the opportunities which present themselves, for the production of oils from any of our fishes; the little that is done, being carried out in a spasmodic kind of way, in connection with a few of the large predaceous Sharks which at times roam in such immense numbers along at least, our eastern coastline.

[In this connection I may mention my conviction that in the near future the Sea Mullet (Mugil dobula) is destined to be of great value as an oil producer. It is one of the most abundant of our food-fishes and is distributed over the greater part of our coastline. During the spawnings season, when such vast shoals congregate together, the liver is full of oil, and the abdominal cavity is thickly lined with fat. Even around the viscera of healthy immature Sea Mullet, as well as of the adults at times other than the spawning season, there is a considerable amount of fat, and, there appears to be no reason why this should not be made use of at the present time. The amount of oil that might be obtained from this source alone, would form no inconsiderable quantity. Of course, I know the statement will be made, that the fishes are sold in such comparatively small lots, as to render the treatment of the offal unprofitable. In my opinion, the answer to this is: Make it absolutely compulsory for the fishernen to "gut" their fish, prior to forwarding it to market. By this action two purposes would be served; the first and most important being that the fish would reach their destination in a better condition (and consequently there would be less of the deplorable waste which goes on in the hot weather at the present time); while, secondly, there would be such accunulations of fish refuse within many comparatively-small areas on many of 
the fishing-grounds, as to render the treatment of it very profitable to all concerned.]

Mention has been made of Fertilizer for agricultural purposes, as a fish-product; and in view of the great possibilities in this direction in Australia, it mav be well to go into some slight detail. In older countries, in nearly all cases where oil is extracted from refuse, the remaining matter is dried and ground up and sold as Fertilizer. But this is not restricted merely to the utilisation of refuse; as, in some cases, extensive fisheries exist in which the sole object is to obtain fish for its commercial products other than food. Where only one species of fish is dealt with, perhaps the most important is the Menhaden fishery in the United States of America, upon which thonsands of men are emplosed-either directly or indirectly. The Menhaden is a fish of the Herring family, which swarms in incalculable numbers in the waters of North America. As a foor product it possesses but little value. However, many millions of them are nised annually as bait, in the Cod-fishery. But far more important is its 11 se as a fertilizer and oilproducer. For this purpose, about $800,000,000$ of this species are used annually in the United States. This enormous total, weighing about 240,000 tons, turned to fertilizer makes abont 86,000 tons, which is worth at first hand

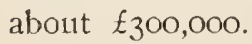

Many other species of fishes are also used in the preparation of fertilizing products; these including even certain well-known food-fishes, when they occur in such numbers as to render their sale for food purposes unprofitable. Amongst the most important of these, may be mentioned the before-mentioned Sharks and Rays (the latter including many species of Sting-rays).

No mention can be made here, of the many important and interesting methods of extracting the oil, or of converting fish or fish-refuse into fertilizer.

Before passing on, I may mention that the most primitive form of ntilising fishes as a fertilizer is to take them and spread them ont over farm land or else to simply dig them in. These methods are practised in many countries at the present day, not being unknown even in New South 
Wales.* Though satisfactory enough with certain kinds of fishes they are hardly applicable to fishes which contain a good deal of oil, as this substance prevents or delays the decomposition which is such a necessary part of the natural conversion of the fish into a suitable form of material for the nourishment of plant life.

The Skins of Fishes are used for a variety of purposes. In most species they are of a gelatinous nature, and are easily soluble in water; but in some, they are of a firmer, stronger and more useful character. Many of the latter may be converted into leather, although their employment for practical purposes at the present time, is strictly limited; these products rather ranking amongst novelty or fancy leathers. In Egypt fish-skin leather is made from fishes of the Red Sea, being converted into soles for shoes. Skins of the fish known as "Burbot" are used after being simply stretched and dried in Russia and Siberia, to trim dresses, and also instead of glass, for the windows of peasants' dwellings, as it is as transparent as oiled paper. Simmonds states that the inhabitants of the eastern coasts of the middle of Asia, clothe themselves with the tanned skins of Salmon; which, it is asserted, make a very tough leather, the scale-marks giving it a very neat pattern. In America, successful experiments have resulted in the manufacture of good leather from the skins of Cod, Cusk, Salmon and others, while shoes and gloves have been made from those of the two first-mentioned. The skin of the Wolf-fish (Anarrhichas) is specially adapted for leather-making and quantities of it have been placed on the market. Eel skins have been used for the thongs of whips, and the attachment of flails; and dried Sole skins for the purpose of clarifying coffee; while the skins of many Sharks and Rays, were used largely in the "pre-sandpaper days" (and are still used to a certain extent by workmen), for the purpose of smoothing and polishing substances, and also to make a kind of shagreen leather. The best shagreen leather (called Galuchat) is said to be made from the skin of the Sephen Sting-

* Instances are known on the coast of New South Wales where sharks have been eut up (after the liver had been removed) and buried in various portions of orchards - the flesh making an excellent fertilizer 
ray (Dasyatis sephen) which is found on the coasts of New South Wales and Queensland, and also in the Indian Ocean, the Red Sea and the Mediterranean Sea. This skin is remarkable for the size of the numerous round, hard protuberances on the skin. These become white by rubbing down, the interior being opaque and nacreous. The skin is sometimes dyed in various colours, but is often left the natural colour, by only half polishing it. Even at the present day the skin from some of the smaller Sharks is used by certain turners, and workers in ebony and ivory, as it is more even and more durable than glass-, sand- or emery-paper. Many miscellaneous skins are valued principally because of their peculiar grains or markings, and are so tanned, as to bring their grains into prominence. These are used principally in small articles such as belts, card-cases, pocket-books, etc., or for covering boxes, writing-cases, sword-grips, etc.

Fish-skins are employed extensively in the preparation of fish-glue.

The Scales of Fishes are used to some extent in the manufacture of glue, and also (recently) in the preparation of gelatine. They are also used for purposes of ornamentation and for the manufacture of artificial flowers. In 1875 the Royal University of Norway, Christiania, sent to the Smithsonian Institute, Washington, U.S.A., a diaden, made from fish-scales and eyes. Ornaments for ladies, made from fish-scales, were, at one time, largely sold at the Crystal Palace, London. The Chinese are said to have a mode of grinding up fish-scales and using the powder as a dry pigment, to give a brilliancy to parts of pictures. In some parts of the world, the scales of large fishes_-such as the Tarpon of America-are treated in such a way, as to make them appear like mother-o'-pearl. They are then worked up into artificial flowers, marquetry articles and other fancy works and in some cases, little scenes are painted on them.

Guanin: The perfectly white solution of the scales of the Bleak (Alburmus lucidus), is now used largely in the production of artificial pearls. This substance is an excrementitious matter, known as "Guanin." Glass bulbs, in the shape of pearls, lined with this substance, make a very close 
imitation of the real gems. These form the inexpensive "pearl necklets" so commonly worn.

Other references to fish-products, will be found scattered through the portion dealing with the fishes themselves.

Very much more might be written about the uses to which fishes are put in the manufacture of products other than food, but sufficient has been said, I think, to give the reader a general idea, so that he may see for himself, what an immense field lies before us in the development of our fisheries.

\section{FOOD VALUE OF AUSTRALIAN FISHES.}

APPARENTLY, no observations have been so far carried out in Australia, with a view of determining the dietetic value of the flesh of our food-fishes. During the course of my work, my friend Mr. W. M. Doherty, F.I.C., F.C.S., kindly undertook to make some analyses so that a beginning in this direction might be made. Mr. Doherty's "results," which are given below, are of the first importance. The figures really speak for themselves, but in regard to the amonint of fat obtained from the viscera of the Sand Whiting I wonld like to supplement Mr. Doherty's remarks in so far as to state that the fish examined was just an ordinary example of a healthy Sand Whiting, and that in my opinion from personal examination the percentage of fat in healthy 'Irumpeter Whiting, Black Bream, and a number of other common fishes would not be less: while in the Sea Mulletparticularly at spawning time-it would be considerably more. I have before me a tube containing the fat-amounting to about a quarter of an ounce-extracted by Mr. Doherty from the viscera of the Sand Whiting. Taking this as a fair average for each fish we find that the amount yielded by a basket of 75 pounds weight would be about $3 \mathrm{I} / 4$ pounds. Now, according to the statistics of a recent year about 4250 baskets of Whiting were marketed; so that from these alone nearly i 4,000 pounds of a valuable fat (or crude oil) might have been obtained!

Referring to his observations, Mr. Doherty writes :-

"In the following table are given the analyses of edible portions of four of the principal food fishes of Sydney from 
a dietetic standpoint. They were selected as being fairly representative of the fish supply of this city, as it was impracticable when this work was mooted, in the time at my disposal to go to any further length in making the table comprehensive. These analyses are but a beginning to what it is hoped will be extended to a complete list.

"The importance of knowing the exact value of all foods is becoming more and more decided, and it is quite probable that at no very distant date, the knowledge gained by work of this description will be actually utilised for the common good.

"At the present time there are differences of opinion as to what constitutes a rational diet, but it is reasonable to expect (apart from palate promptings which must always be considered) that sooner or later these will be adjusted, and the waste that now undoubtedly goes on be at least minimised. To this end is such work as this contributed.

"The fish examined were the Sea Mullet, Black Bream, Sand Whiting, and River Garfish. Each fish was mature; fresh, and in very fine condition. The muscular tissue was clear and firm. Portions for analysis were removed from the side, near the back.

"The Sea Mullet has the reputation of being excessively oily, but such is not supported in the analysis, which shows that in this respect, practically little difference exists between it and the Black Bream. With the exception of a little more fat in the case of these two fish, all four are, weight for weight, nearly of the same value dietetically; and apart from the question of ease of digestibility, are equal to lean beef.*

"While examining the Whiting, my attention was drawn to the large proportion of fat present in the entrails. These weighed I2.9 grammes and yielded 7.37 grammes of fat. This is a yield of 57 per cent. of a valuable commodity, calculated on the entrails, or a quarter of an ounce per fish."

* Fish are classed in regard to fat content as "fat," "medium" aud "lean." Fat fish are those that contain more than 5 per cent., as the Eel (10 per cent.), Salmon (12 per cent.), and Herring (8 per cent.) of Europe. Medium fish, those with from 2 to 5 per cent., as our Sea Mullet and Black Bream. Lean, under 2 per cent., as our Sand Whiting and River Garfish, and the Furopean Corl.--IV.M.D. 


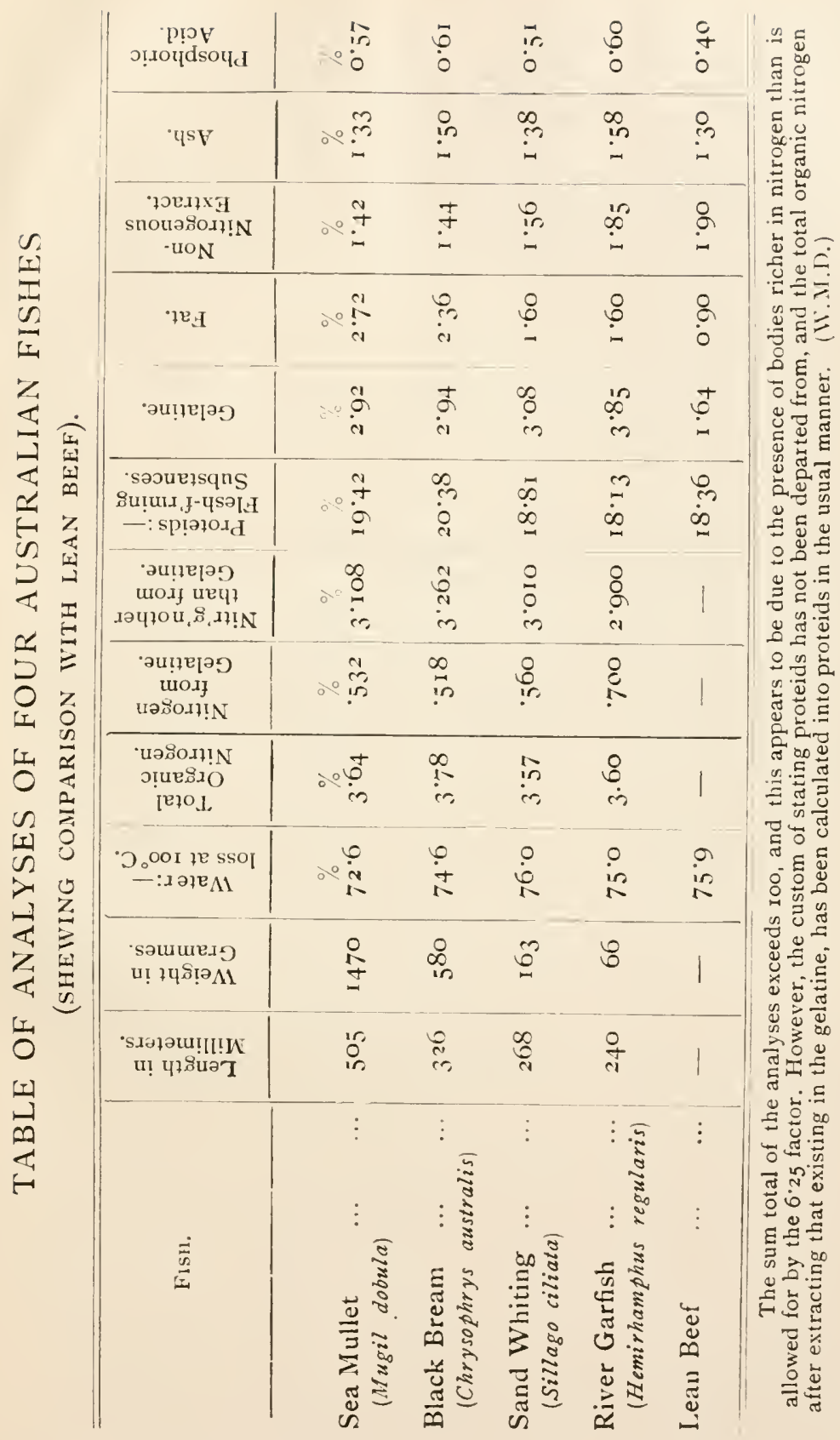





\section{APPENDIX.}

\section{LIST OF THE PRINCIPAL EDIBLE FISHES OF AUSTRALIA; WITH, ALSO, THE STATES IN WHICH THEY CHIEFLY ABOUND.}

Common Name.

SPECIES.

Found PRINCIPALLY

IN :-
Ox-eye or Big-eyed Herring
Giant Herring.
Barramundi
Salmon Herring.

. Vegalops cyprinoiales

E?ops saurus

Scleropages leichnar.?ti

Chanos chanos

Bony Bream. "Pibrie" or Dorosoma erebi "Tookery."

Pilchard or Maray.

Herring.

Freshwater Herring.

Freshwater Catfish.

Commion Eel.

Australian (irayling.

Sergeant Baker.

Slender Long- Iom.

Stout Long-Tom.

Sea riarfish.

River Garfish.

barred Garfish.

Short-beaked Garfish.

Siez Mullet.

Richmond Mullet.

Silver Mullet.

Diamond_scaled Mullet.

Flattail Mullet or "Ty. gum."

Sand Muilet or "Tallegalane."

lellow-eye Mullet.

Short-finned Pike.
Clupanodon neopilch irdus

Saidineila castelnaui

Potamalosa nover-hollandice

Copidoglanis tandanus

Anguilla reinharatii

Prototroctes marena

Aulopus purpurissatus

Tylosurus ferox

Tylosurus macleayana

Hemirhamphus intermedius

Hiemirhamphus regularis

II mirhamphus far

Arrhamphus sclcrolepis

IIngil dobula

Wugil peturdi

Mugil georgii

Mugil waigiensis

Mugil peronii

II yxus elongatus

Agonostomus forsterz

Sphyrena nove-hollandice
Q.

Q.

Q.

Q

N.S.W., Q., and S.A.

N.S.W., Vic, Q., and Tas.

N.S.W. and Q.

N.S.W. and Vic.

N.S.W., Vic., and Q.

N.S.W., Vic., and Q.

Tas.

N.S.IV.

N.S.W

N.S.W

N.S.W. and (?.

N.S.W.

Q.

N.S.W. (North) anı? Q.

N.S.W., Vic., Q.. S.A., W.A., Tas.

N.S.W.

N.S.W. and Q.

Q.

T.S.W. and Q.

N.S.W. and Q.

Vic., S.A., W.A., and Tas.

N S.W., Vic., and S.A. 


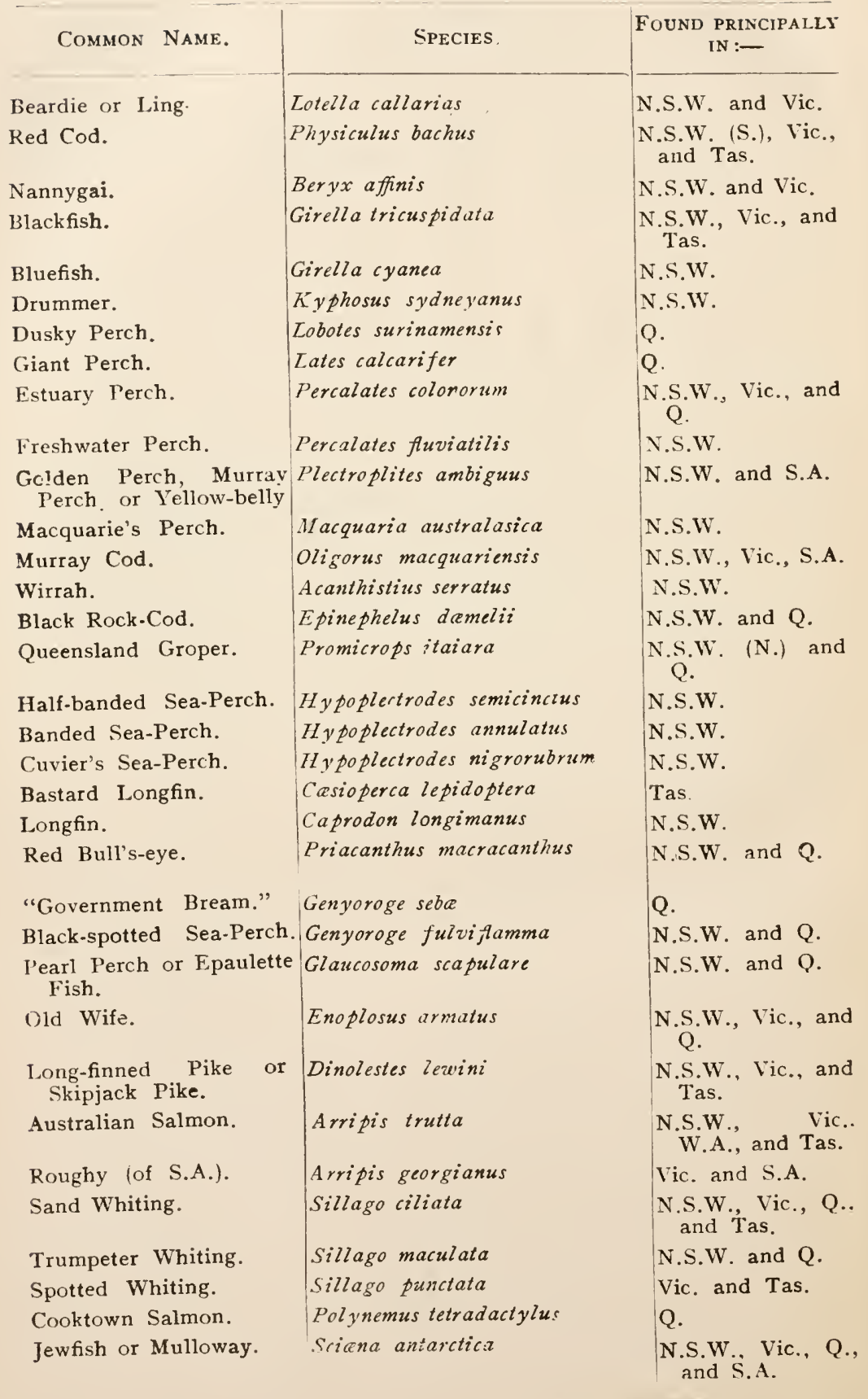




\begin{tabular}{|c|c|c|}
\hline Common Name. & SPECIES. & $\begin{array}{c}\text { FOUND PRINCIPALLY } \\
\text { IN :- }\end{array}$ \\
\hline Teraglin. & Cynoscion atelodus & N.S.W. \\
\hline Silverbelly. & Xystama oratum & N.S.W. \\
\hline Bastard Trumpeter. & Latris ciliaris & $\begin{array}{l}\text { N.S.W., Vic., and } \\
\text { Tas. }\end{array}$ \\
\hline Trumpeter. & Tatris hecuiteia & Tas. \\
\hline Kelp-Fish. & Chironemus marmoratus & $\begin{array}{l}\text { N.S.W., } \text { Vic., } \\
\text { W.A., and Tas. }\end{array}$ \\
\hline Cockatoo-Fish. & Aplodactylus lophodon & N.S.W. \\
\hline Morwong. & Dactylosparus carponemus & N.S.W. M M \\
\hline Jackass_Fish. & Dactylosparus macropierus & $\begin{array}{l}\text { N.S.W., Vic., and } \\
\text { Tas. }\end{array}$ \\
\hline Sea-Carp or Red Morwong & Cheilodactylus fuscus & N.S.W. \\
\hline Dusky Morwong. & Cheilodactylus nigricans & N.S.W. and Vic. \\
\hline Trumpeter Yerch. & Terapon quadrilineatus & N.S.W. and Q. \\
\hline Silver Perch or Grunter. & Terapon ellipticus & $\begin{array}{l}\text { N.S.W., Vic., Q.., } \\
\text { S.A.. and W.A. }\end{array}$ \\
\hline $\begin{array}{l}\text { Queensland Trumpeter } \\
\text { or Javelin-Fish. }\end{array}$ & Pomadasis hasta & Q. \\
\hline Boar-Fish. & Histioptenus recurvirostris & Vic. and Tas. \\
\hline Giant Boar-Fish. & Histiopterus labiosus & N.S.W. and S.A. \\
\hline Snapper. & Pagrosomus auratus & $\begin{array}{l}\text { N.S.W., Vic., Q., } \\
\text { S.A., w.A. }\end{array}$ \\
\hline Tarwhine. & Chrysophrys sarba & N.S.W. and Q. \\
\hline Bream. & Chrysophrys australis & $\begin{array}{l}\text { N.S.W., Vic., Q., } \\
\text { S.A., Y.A., and } \\
\text { Tas. }\end{array}$ \\
\hline Vellow-mouthed Perch. & Lethrinus chrysostomus & Q. \\
\hline Plue-striped Goatfish. & Upeneus porosus & N.S.W. and Vic. \\
\hline Moon-Fish. & Drepane punctata & \\
\hline Sweep & Scorpis aquipinnis & N.S.WV. \\
\hline Butter_Fish. & Ephippus multifasciatus & $\begin{array}{l}\text { N.S.W., Q., and } \\
\text { W.A. }\end{array}$ \\
\hline Spotted Butter-Fish. & Ephippus argus & Q. \\
\hline Black Trevally. & Siganus nebulosus & N.S.W. and Q. \\
\hline Spotted Pigfish. & Diastodon unimaculatus & N.S.W. \\
\hline Banded Pigfish. & Diastodon bellis & N.S.W. \\
\hline Blue-spotted Groper. & Charops ommopterus & N.S.WT. and Q. \\
\hline Hlue Groper. & Acharodus gouldii & N.S.W. and Tas. \\
\hline Red Groper. & Achorodus baduus & N.S.W. \\
\hline White-spotted Parrot-fish. & Pseudolabrus gymnogenis & N.S.W. \\
\hline $\begin{array}{l}\text { Crimson-banded Parrot- } \\
\text { fish. }\end{array}$ & Pseudolabrus nigromarginatus & N.S.W. \\
\hline Maori or Rainbow-Fish. & Coris lineolatus & N.S.W. \\
\hline Rock Whiting or Stranger. & Odax richardsonii & $\begin{array}{l}\text { N.S.W., Vic., and } \\
\text { Tas. }\end{array}$ \\
\hline
\end{tabular}


Common Name.

Species

Odax baltealus

Little Rock Whiting

Herring-Kale.

Queen-Fish.

Pilot-Fish.

King-Fish.

Samson_Fish.

Mackerel-Scad or "Cowanyung."

Yellowtail.

Trevally.

Dart.

Tailer or Skipjack.

Sergeant-Fish or West Indian Kingfish.

Common Mackerel.

Bonito.

Horse-Mackerel.

Olisthops cyanomelas

Scomberoides sancti-petri

Naucrates ductor

Seriola lalandi

Seriola hippos

Decapterus leptosomus

Trachurus declizis

Caranx georgianus

Trachinotus baillonii

Pomatomus saltatrix

Rachycentron canadus

Scomber colias

Gymnosarda pelamis

Sarda chilensis

Barred Spanish Mackerel. Spotted Spanish Mackerel. Barracouta.

Scomberomorus commersonii

Scomberomorus guttatus

Thyrsites atun

Dolphin-Fish.

John Dory.

Silver Dory.

I.arge-toothed Flounder.

Small-toothed Flounder. Queensland Halibut.

Long-snouted Flounder. Southern Flounder.

Peacock Sole.

Black Sole.

Coryphana hippurus

Zeus australis

Cyttus australis

Paralichthys arsius

Paralichthys nova.cambria

Psettodes erumei

Anmotretis rostratus

Rhombosolea monopus (?plebeia) Achirus pavoninus

Synaptura nigra

Tongue-Fish or Lemon Sole. Symphurus unicolor

Red Furnet-Perch.

Red Rock-Cod.

Isill-rout.

Common Flathead.

Rock Flathead.
Sebastapisles percoides

Scorpana cruenta

Nolesthes robusta

Platycephalus fuscus

Platycephalus lavigatus
FOUND PRINCIFALLY IN :-

N.S.IW., Vic., and Tas.

N.S.W. and Vic.

Q.

N.S.W.

N.S.W.. Vic., Q., and Tas.

N.S.W.

N.S.W.

N.S.W.. Vic., Q., and Tas,

N.S.W.. Vic., Q., and Tas.

N.S.W. and Q.

N.S.W., Vic., Q., S.A., W.A., and Tas.

N.S.W.

N.S.W., Vic., and W.A.

N.S.W. and Vic.

N.S.W.

N.S.W. and Q.

N.S.W.

Vic., S.A., and Tas.

N.S.W.

N.S.W., Vic., and Tas.

Tas.

N.S.W. and Q

N.S.W.

Q.

N.S.W., Vic., Tas.

Vic. and Tas.

N.S.W. and Q.

N.S.W. and Q.

N.S.W. and Q.

Vic. and Tas.

N.S.W., Vic., and Tas.

N.S.W. and Q.

N.S.W. and Q.

Vic. and Tas. 
Common Name.

Bass Flathead.

Long-spined Flathead or Platycephalus longispinis "Spikey" Flathead.

Red Gurnard.

Chelidonichthys kumu

Sharp-beaked Gurnard.

Flying Gurnard.

Sandy or Congolly.

SpEcies
Platycephalus bussensis
Platycephalus longispinis
Chelidonichthys kumu
Pterygotrigla polyommata
Cephalacanthus spinarella
Pseudaphritis uritlii

River Blackfish, Slippery Gadopsis marmoratus or Marbled River-Cod.

Orange-spr.tted Leather-Monacanthus hippocrepis jacket.

Yellow Leatherjacket or Monacanthus ayraudi "Chinaman."

FOUND PRINCIPALLY IX: :-

N.S.W., Vic., and Tas.

N.S.W.

V.S.W.

V.S.W., Vic, and Tas.

N.S.W. and Q.

Vic., S.A., and Tas.

N.S.W., Vic., and Tas.

N.S.T. and Tas.

N.S.IV.

\section{ADDENDEM.}

I1 dealing with the lilennies (p. 210) I mentioned only the commoner kind of Crested Weed-lish-Cristiceps macleayi-and omitted to remark upon the subject of our Frontispiece-Cristiceps aurantiacus-which is less frequently met with. This exceedingly handsome fish attains, usually, a somewhat larger size than Cristiceps macleay 2 , and generally does not exhibit the vertical bars (along the body) which are such a prominent feature in freshly-caught examples of the latter species. Another rather important distinguishing character is that the first dorsal fin in Cristiceps aurantiacus begins slightly in advance of the eyes, while in Cristaceps macleayi it begins over the hinder margins of the eyes.

Other species of Cristiceps also inhabit Australian waters, but are rarely obtained.

\section{CORRIGENIA.}

l'age 20: Excise "Nandide" and include "Bleeker's Plesiops" with the Perches (Serranida).

Page 106: For "xxix." read "xxxix." 



\section{INDEX.}

A.

Acanthistius serratus ... 96,262 Acanthopterygii ..... 20, 2 I, 22 Acanthwrida .......... 21, 137 Achirus paroninus ..... 183, 264 Acherodus gouldii ...... 142, 263 Acherodus badius ........ 16, 263 adspersus, Krefftius ....... 185 requipinnis, Scorpis ...... I 33, 263 Aëtobatis narinari $\ldots \ldots \ldots .233$ affinis, Beryx ........ 87, 262 Agonostomus forsteri .. I 5, 74, 26 I alalunga, Germo .......... 162 Albacore ............. 162, 165 Alectis ciliaris .......... 149 Alefidosaurida $\ldots \ldots \ldots \ldots$ 19, 55 Alepidosaurus ferox ........ 55 Alepocephalide ........... 19, 36 Alepocephaloids ............. $3^{6}$ Alepocephalus niger .......... $3^{6}$ alfredi, Manta .......... 233 Alopias wulpes ............. $233^{2}$ ambiguus, Plectroplites ... 96, 262 American Brook-Charr ..... $3^{6}$ amissus, Macrius .......... $2 \mathrm{O}_{4}$ A mmotretis rostrata ...... $183, \quad 264$ Amphioxus .............. 240 Amphiprion bicinctus ........ 140 A mphiprion melanopus ........ I4I Amphiprion percula ......... $\mathbf{1}_{40}$ Anacanthini $\quad . . \ldots \ldots \ldots \ldots .20$ Anchor'y $\ldots \ldots \ldots \ldots \ldots .27,3^{1}$ Anema inerme ............ 206 Angel Shark $\ldots \ldots \ldots \ldots .233,236$ Angler-Fishes ........... 218 Angler-Fish, Striped ...... 218 Anguilla australis .......... 44 Anguilia rcinhardtii ... 43, $26 \mathrm{I}$ Anguillida $\quad \ldots \ldots \ldots \ldots \ldots$ 19, 43 annulatus, Hypoplectrodes .... 262 anolis, Petroscirtes ........ 210 antarctica, Sciana ....... 113, 262 Antennariide ...........22, $21 \mathrm{IS}$ Antennarius nummifer ....... 219 Antennarius striatus ......... $2 \mathrm{I} 8$ antipodum, Engraulis ....... 27 Aploactis milesii .......... $19 \mathrm{I}$ Aplodactylide $\quad . . . . . . .2$ 2I, II9 Aplodactylus lophodon .. I I9, 263 Apodes .................. 19 Apogon fasciatus ........... $9^{6}$ Aracana lenticularis ....... 224 argenteus, Monodactylus ...... I 33
Pags.

argus, Ephippus ....... 137, 263 armatus, Enoplosus ..... 96, 262 Arrhamphus scleroletis ... 64, 26I Arrifis georgianus ...... I1 7,262 Arripis trutta ......... I I 3,262 arsius, Paralichthys ...... I 78,264 atelodus, Cynoscion .... I 13,263 Atherina lacunosa ........... $7 \mathrm{I}$ Atherinida $\ldots \ldots \ldots \ldots . . .20,7 \mathrm{I}$ atun, Thyrsites ........ 166, 264 Atypichthys strigatus ....... 133 Aulopus purpurissatus, 15, 53, 261 auratus, Carassius ......... $3^{8}$ auratus, Pagrosomus .. 15, 125, 263 australasica, Macquaria .. 96, 262 Australian Band-Fish ..... I08 Australian Cling-Fish ..... 209 Australian Grayling ... 5 I, 26I Australian Hairtail .... I66, 168 Australian John Dory ..... 175 Australian Knife-jaw ....... rog Australian Knight.Fish ..... 89 Australian Lung-lish ..... 229 Australian Minnows ........ 49 Australian Rockling ....... 2 I5 Australian Salmon ........ 262 Australian Sea-Dragon ...... 63 Australian Smelt .......... $3^{2}$ australis, Anguilla ........ 44 australis, Cepola ........... 108 australis, Centropogon ..... IOI australis, Chrysophrys I 5, 125.

259, 263 australis, Cyttus....... 176, 264 australis, Galeichthys ... 40, $4^{2}$ australis, Geotria ........... 240 australis, Krefftius ......... 184 australis, Macrurus ......... 85 australis, Myliobatis ....... 233 australis, Periophthalmus .... I 84 australis, Zetis ......... 175, 264 "yraudi, Monacanthus 22I, 222, 265

B.

bachus, Physiculus ...... 86, 262 badius, Acharodus ........ 16, 263 baillonii, Trachinotus ....... 264 Balistida ..............22, 220 balteatus, Otax ........ 147, 264 Band-Fish, Australian ....... 108 Band-Fishes ............. I 8 \& Banded Pigfish, ......... 143, 263 
Banded Sea-Perch Page.

Banded Shore-Eel ............. 43

banksii, Rhinobatus ........ 233

bartatus, Orectolobts ........ 232

Barracouta ........ I $6(t), 167,264$

Barracouta Family .......... I6 65

Barramundi .......... 25, 26r

Barred Ciarfish .......64, 68, 26r

Barred Spanish Mackerel .... 264

Bar-tailed Goat-lish .... I31, $13^{2}$

Basking shark ....... 233, 235

bassanum, Branchiostoma ..... 240

bassensis, Platycephalus ..... 265

bassensis, sillago .......... I I I

Bass Flathead ............ 265

i3astard Jongfin .......... 262

Bastard Trmmpeter ..... I 8,263

Batfish ............. I 33, I 34

Batrachide ........... 22, 213

Batrachus dubius ......... 214

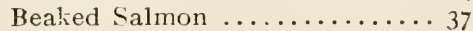

Beardie ............. 86, 262

belcheri, Branchiostoma ....... 240

Bellows-Fish ............. 59

Bellows-Fishes $\ldots \ldots \ldots \ldots . . . . .59$

Bellows.Fish, Little ....... 59

Berycide ............. 20, 87

Bervx affinis ........... 87, 262

bellis, Diastodon ........ 143, 263

Bettu pugnax ............. 39

licinctus, Amphiprion ....... I40

bifrenatus, Gobius .......... I $8_{4}$

Big-eyed Herring .......... 23

blacodes, Genypierus .........2 2 I 5

Black Bream I6, 1 25, 1 28, 259, 263

Blackfish .......... I6, 91, 262

Blackfish Family ............ 9

Blackfish, River .......2 210,265

Black Rock-Cod ...... 96, 103, 262

Black Sole ......... I $7^{8}$, I 81,264

Black-Spotted Sea-Perch ..... 262

Black Stingray ........... 233

Black Trevally ........ ז 39, 263

Black Trevally lianily ...... $3^{8}$

Blennies ............... 2 I0

Blcnniide ............ 22, 2 10

Blenny, Hair-tailed ..... 210, 2 I 3

Blenny, Oyster ....... 2ro, 2 I I

Blind Tassel-Fish ........ 82

Blue-eye ............. $7^{1}, 7^{2}$

Bluefish ........... 91, 93, 262

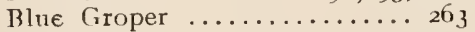

Blue Pointer ............. 233

Blue Shark .............. 232

Blue-spotted Ciroper ......... 263

Blue-Striped Goatfish .... I $3 \mathbf{1}, 263$

Boar-Fishes ............. I 22

Boar-Fish, Giant .... I 22, I 24,263

Boar-Fish, Richardson's I 22, I 24 ,
Bonito ......... 162. IU $4, \begin{array}{r}\text { Pagk. } \\ 26.4\end{array}$ Bony 13rean ......... 27, 31, 26 I Bowichthys variegatus ....... 205 Box-lishes ............. 224 Box-Fish, Forned ......... 224 Box-Fish, Lenticular ........224 l3ox-lish, Linked .......... 224 brachyurus, Carcharins ...... 232 Brama rati ............. 174

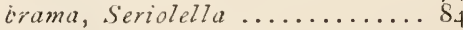
Bramide ............21, 174 Branchiostoma bassanum ...... 240 Branchiostoma belcheri ....... 240 Branchiostoma cultellum ..... 24n Branchiostomatide ......... 2.40 Bream, Black ... I6, I 25, I 28, 259 Brean lamily ............ I 25 Bream, Government ...... 262 Bream, Red .............. I 26 13ridled Goby ............ $18_{4}$ Brouk Charr, American ...... $3^{6}$ Brown Groper ............. I6 Brown Trout .............. $3^{6}$ bucculenta, Trygonoptera ..... 233 Bullheads ............... 234 Bullrout .......... I9 I, I93, 264 Bull's-eye, Large-Sicaled ...... 90 Bull's-eye. Red ........... 262 Bull's-eyes ................ 90 Bull's-eye, Small-scaled ........99 Butter-Fish ....... I 35, I 36,263 Butter-Fish, Spotted ...... I 37, 263 Butterfly-Fish, Japanese ..... 39

$$
\text { C. }
$$

C'esioperca lepidoptera ....... 262 calauropomus, Callionymus ... 209 calcarifer, Lates........ 96, 262 callarias, Lotclla ....... \$6, 262 Callionymida ......... 22, 208 Callionymus calauropomus .... 209 Caliionymus curvicornis ...... 208 canudus, Rachycentron .. I 59, 264 Caprodon longimanus ........ 262 Carangida ........... 21, 149 Caranx georgianus .. I6, I49, 264 Carassinps compressus ....... I 84 Carassius auratus .......... 38 Carcharias brachyurus ..... 232 carcharias, Carcharodon ..... 233 Carcharodon carcharias ..... 233

Carpet Shark ........... $23^{2}$

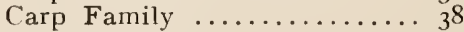

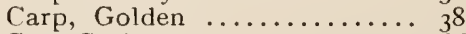
Carp-Gudgeon ......... I 84 , I 86 carponemus, Dactylosparus 1 19, 263 castclnaui, Sardinella .... 27, 26 I Catfish, Estuary ....... 39, 40 Catfish Family ........... 39 
Pivie.

Catfish, 1reshwater .. 39, 40, 261

Catosteomi ............... 20

caudatus. Iepidopus ......... 167

Centrarchide ........... 20, 91

Centrarchoid Fishes ........ 91

Centriscide ............ 20, $5^{8}$

Ceniriscus gracilis ......... 59

Centriscus icolopax .......... 59

Centropogon australis ...... $19^{1}$

Cephalacanthide ........ 21, 202

Cepinaiacanthus spinarella 202, 265

('ephalochordata ......... 240

Cepola australis ............ 108

Cepolide ...................... 20, 108

Cetorhinus maximus ......... 233

Chatodon strigatus ......... 135

Chætodon, Striped ...... I 35, $13^{6}$

Chactodontide ......... 21, I 35

Chanos chanos .......... 27, 261

Cheilobranchus rufus ....... 43

Cheilodactylus fuscus .... II 9,263

Cheilodactylus nigricans ..... 263

Chelidonichthy's kumu 16, 200, 265

Chelmonops truncatus ....... 135

chilensis, Sarda ...... 162, 264

Chimera ogilbyi ......... 233

Chirocentride ........... 19, 26

Chirocentrus dorab .......... 26

Chironemus marmoratus .. I 8,263

Cherops ommopterus ........ 263

Chrysophry's australis 16, 125.

259,263

Chrysofiry, sarba ..... 125,263

chrysostomus, Lethrinus .. 125,263

ciliaris, Alectis .......... 149

ciliaris, Latris ......... 118, 263

ciliata, Sillago... I 5, Io9, 259, 262

cinereus, Muranesox ........ 44

cirratus, Pristiophorus ....... 233

cirronasus, Platycephalis .... 197

Climbing-Fish ........... 186

Cling-Fish, Australian ..... 209

Cling-Fishes ........... 209

Clouded Eel .............. 44

Clupanodon neopilchara'us. 27, 26I

Clufeide ............. 19, 27

Cnidoglanis megastomus ...... 39

Cockatoo Fish ..... 1r9, 121, 263

Cod Family ............. 86

Cod, Murvay ....... 96, 99, 262

Cod, Red .......... So, 87,262 colias, Scomber ......... 162, 264 colonorum, Percalates .. I5, 96, 202 commersoniz. Scomberomorus 162, 264 Common Dolphin-Fish ..... I 73 Common Eel ..........4 43, 44

Conimon Flathead ...... 197, 264 Common Mackere] ......... 264

Conimon Sea-Horse ........ 61
Pagi:

Consmon Stingray ..... 233, 237

Comımon Sun-Fish ........ 228

compressus, Carassiops ....... 184

compressus, Pempheris ........ 90

concatenatus, Lactophrys ..... 224

Corger Eel .......... 44, 48

Cooktown Salmnil ....... 81, 262

Copidoglanis tandanus .... 40, 261

Coral-Fish ....................... 135

Coral-Fishes ........... I 35

Coris lineolatus ...... 16, 142, 263 cornutum, Ostracion ......... 224 Corvfhana hippurus .... 17,3, 264 Corl'phenida .... .. .. 2I, 172 Corythcenoides variabilis ..... 86 costatus, Diplocrepis ........ 209

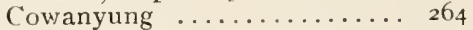
coxïi, Galaxias ............ 50 coxii, Trichiurus ......... I66 Creedia haswelli .......... 207 Crested Flounder .......... ${ }_{18} 8$ Crested Port Jackson Shark .. $23^{2}$ Crested Weed-Fish ......2 210, 2 I 2 Crimson-banded Parrotfish .. $26_{3}$ Cristiceps macleayi ......... 2 Io crucnta, Scorpena ....... I91, 264 cultellum, Branchiostoma ..... 240 curvicornis, Callionymus ...... 208 cuvieri, Tetragonurus ....... 84 Cuvier's Sea-Perch ...... I 5, 262 Cuvier's Square-tail ........ 84 cyanea, Girella ......... 91, 262 cyanomelas, Olisthops si, 142, 264 Cyclostomata ............. 239 Cynoscion atelodus ...... I13, 263 cyprinoides, Megalops .... 23, $26 \mathbf{I}$ Cyprinida .............. 19, $3^{8}$ Cypsilurus melanocercus ....64, 70 Cvitus australis ....... 176, 264

\section{D.}

Dactylosparus carfonemus 119,203 Daciylosparus macropterus 119,203 demelii, Epinephelus .... ob, 262 Dart ................... 264 Dasyatis sephen .......... 233 Dasyatis thetidis .......... 233 Deiapterms leptosomus ....... 264 declizis, Trachurus .. 10, 149, 264 depressa, Fistularia ........ $5^{8}$ Diamond-scaled Mullet $74,79,261$ Diastodon bellis ........ $\mathbf{I}_{4}, 26_{3}$ Diastodon unimaculatus.. 142,263 Dicotylichthys punctulatus .... 226 Dinolestes lewini ....... 96, 262 Diodon hystrix ........... 227 Diodontida ............ 22, 226 Diplocrepis costalus ... ..... 209 


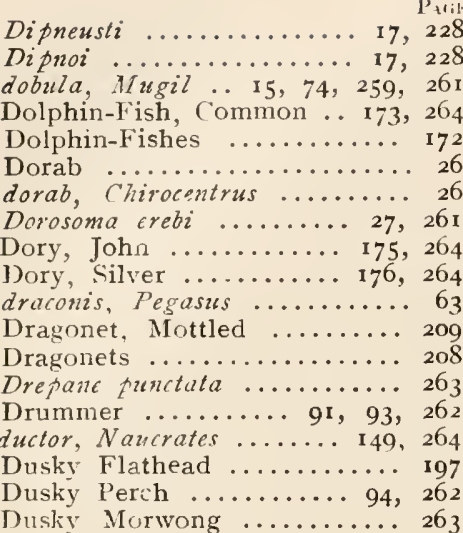

\section{$\mathrm{E}$}

Eagle-Ray ............. 233

Eagie-Ray, Spotted ........ 233

Ecnencidide ........... 21, 189

Echeneis naucrates .......... IgI

Echidna nebu? osa ........... 44

Eel, clonded ............. 44

Eel, Common ......... 43, 44

Eel, Conger $\ldots \ldots \ldots \ldots \ldots$ 44, 48

Fel, Green ............ 44, 48

Eel-like Goby ........ I 84 , 187

Eel, Long-finned ...... 44, 261

Eel. Yainted ............. 44

Eel. Serpent $\ldots \ldots \ldots \ldots \ldots$ 44, 48

Eel, Short-finned .......... 44

Eel, Silver ........... 44, 48

Eels, True .............. 43

Elasmobranchii ......... 17, 231

ellipticus, Terapon ..... 122, 263 elongatus, Myxus ... 74, 75, 26 I

Elofidce .............. r9, 23

Flops saurus .......... 23, $26 \mathbf{1}$

Emperor $\ldots \ldots \ldots \ldots \ldots \ldots \ldots$ 1 30

Engraulis antipodum ........ 27

Enoflosus armatus ....... 96, 262

Epiizpus argus ........ I 37,263

Ephippus multifasciatus . I 35,263

Epinephelus damelii ...... 96, 262 crebi, Dorosoma ........ 27, 261 erumei, Psettodes ....... I 78,264 Fstuary Catfish ........ 39, 40 Estuary Perch ....... 15, 96, 2002 evolans, Exocetus ............ 7I Exocatus cvolans .............. $7^{1}$

F.

far, Hemirhamphus .... 64, $26 \mathrm{r}$ fario, Salms ................ 36 fasciatus, Apogon .......... PG 96

fasciatus, Limnichthys ..... 207

fercx, Alepidosaurus ........ 55

ferox, Tylosurus .......6.64, 261

Fiddler .............. 233

Fierasfer .............. 57

Fierasferide .......... 19, 56

Fierasferoids .............56

Fighting-Fish $\ldots \ldots \ldots \ldots \ldots \ldots 39$

Filefishes ............... 220

fundlayi, Galaxias .......... 50

Fire-fish, Red ........ 191, 195

Fistularia depressa ......... 58

Fistulariide .......... 20, 57

Flag-tail .............. $9 \mathbf{1}$

Flat-Fishes ............ I 77

Flathead, Bass ........... 265

Flathead, Common .. 16, 197, 264

Flathead, Dusky .......... 197

Flathead, Long-spined $197,198,265$

Flathead, Rock .... 197, 198, 264 Flatheads ............. 196 Flathead, Variegated .... 197, I98 Flattail Mullet .. 15, 74, 78, 26r Flounder, Crested ........ 183 Flounder, Large-toothed 178,264 Flounder, Long-snouted 183, 264 Flounder, Small-toothed I 78 ,

179,264

Flounder, Sonthern 178, 181, 264 Flute-mouths $\ldots \ldots \ldots \ldots \ldots .657$ fuviatilis, Percalites 96, 97, 262 Flying-Fish $\ldots \ldots \ldots \ldots 664,70$ Flyıng-Fishes $\ldots \ldots \ldots \ldots \ldots 64$ Flying-Gurnard ...... 202, 265 Flying Gurnards ......... 202 foliatus, Phyllopteryx ...... 62 fontinalis, Salvelinus ........ 36 forsteri, Agonostomus 15, 74, 26I forsteri, Neoceratoäus ....... 229 forsteri, Scombresox ...... 15, 64 Fortescue ........... 191, 194 Fox Shark .......... 232, 235 Freshwater Catfish .. 39, 40, 26I Freshwater Herring .. 27, 30, 26r Freshwater Perch .... 96, 97, 262 Frog-lish ............ 214 Frog-Fishes ............ 213 fronto, Patacus ............ 210 Frost-Fish .......... 167, 168 fulvijlanma, Genyoroge ..... 262 fuscus, Cheilodactylus .. II9, 263 fuicus, Platycephaius 16, 197, 264

G.

Gaärde .............. 20, 86 Gadopsis marmoratus .... 210, 265 
PAGE.

Galaxias coxii .............. 50

Galaxias findlayi ........... 50

Galaxias scriba ............. 50

Galaxias truttaceus .......... 50

Galaxiide ............ 19, 49

galeatus, Heterodontus ...... 232

Galeichthys australis ..... 40, 42

Galeichthys thalassinus .... 40, 42

Galeocerdo rayneri .......... 232

galius, Lophonectes .......... $18_{3}$

Garfish, Barred ..... 64, 68, 26r

Garfishes ............... 64

Garfish, River ... $6_{4}, 67,259,26 \mathbf{r}$

Ga:fish, Sea ......6 64, 66, $26 \mathrm{r}$

Garfish, Short-beaked 64, 68, 26 I

Garfish, Skipper ...... 15, 64, 70

geminatus, Lepidoblcnnius.... 210

Genypterus blacodes ......... 215

Genyoroge fulviflamma ...... 262

Genyoroge seba ............ 262

georgicnus, Arrifis ..... 117, 262 georgianus, Caranx .. I6, 149, 264 georgii, Mugil ........... 26r

Geotria australis ............. 240

Germo alalunga ............... 162

Gerrida .................. 117

Ghost Shark .............. 233

Giant Boar-Fish ........ I22, 1 24, 263

Giant Herring ........23, 24, 26 r

Giant Herrings $\ldots \ldots \ldots \ldots \ldots .23$

Giant Perch ..............

Girella cyanea ...........99. 262

Girella iricuspidata........ ${ }_{5} 9^{11}, 262$ gloria-maris, Monocentris ... 89 glauca, Lamna ............. 233 glauia, Prionace ............... 233 Glaucosoma scapulare ........ 96, 262 glesne, Regalecus ............ 217 Glyptauchen panduratus ...... I9 Gnathypops jacksoniensis ..... 108 Goatfish. Bar-tailed ...... I 31 , 132 Goatfish, Blue-striped .... I I 1,263 Goatfishes ............ 130 Goatfish, Spotted ........... 1 $3^{1}$ Gobiesocide ...............2, 209 Gobiide ................. 21, 18 Gobioides furpurascens ....... 184 Gobius bifrenatus ............ 184 Goblin-Fish ........... 191, 195 Goby, Bridled ........... 184 Goby, Eel-like ........... 184 Goby Family ............. 183 Golden Carp .............. $3^{8}$ Golden Perch ....... 96, 97, 262 Goldfish ................ $3^{8}$ Gonorhyncinide .......... 19, 37 Gonorhynchus gonorhynchus .... 37 gouidii, Achcerodus ...... 142,265 Government Bream ......... 262 gracilis, Centriscus ......... 59
Page:

Grayling, Australian ..... 51, 26 I Grayling Family ........... 5 Grayling, New Zealand ....... $5^{\text {I }}$ Green Eel ............ 44, 48 Grenadiers ............... 85 Grey-Nurse ...........233, 235 gronovii, Nomeus .......... 85 Groper $\ldots \ldots \ldots \ldots$ 142, 143, 263 Sroper, Blue .............. $26_{3}$ Groper, Blue-Spotted $\ldots \ldots \ldots, 263$ Groper, Queensland .. 96, 103, 262 Groper, Red (Brown) .... 16, 263 Grunters .............. 122 Gudgeon, Purple-striped ...... 185 Gudgeons .............. 184 Gudgeon, Striped ....... I 84,185 guntheri, Monacanthus ...... 223 Gurnard, Flying .......202, 265 Gurnard, Kumu ........... 200 Gurnard, Red ....... 16, 200, 265 Gurnards .............. 199 Gurnards, Flying ......... 202 Gurnard, Sharp-beaked 200, 201, $26_{5}$ Gurnet-Perch, Red ...... 191, 264 Gurnets ................ 199 guttatus, Scomberomorus .. 162, 264 gymnogenis, Pseudolabrus .. 16, $2 \mathrm{O}_{3}$ Gymnosarda pelamis ..... 162, 264 Gymnothorax picta .......... 44 Gymnothorax prasina ........ 44

H.

Hag-Fishes ........... 239

Hatrtail, Australian ........ I68 Hair-tailed Blenny ..... 210, 213 Half-banded Sea-Perch ....... $26_{2}$ Halibut, Queenslard $578, \mathbf{1 8} 1,264$ hamiltoni, Tetrodon ......... 225 Hammer-headed shark ..... $23^{2}$ Haplochitonide .............. 5 Haflomi ................... I9 Hardyhead ............... $7^{\mathrm{I}}$ Hardyhead Family ......... $\eta^{1}$ hasta, Pomadasis ....... 122, 263 haswelli, Creedia ........... 207 hecateia, Latris ........ II, 263 Hemirhamphus for .......64, 26 I Hemirhamphus intermedius 64, $26 \mathrm{r}$ Hemirhamphus regularis $64,259,261$ Herring $\ldots \ldots \ldots \ldots \ldots 27,29,261$ Herring, Big-eyed ....... 23, 26r Herring Family ........... 27 Herring, Freshwater .. 27, 30, 261 Herring, Giant ......23, 24261 Herring-Kale $\ldots .16,142,147,264$ Herrings, Giant..$\ldots \ldots \ldots \ldots 23$ Heterodontus galeatus ........ 232 Heterodontus philifpi ....... 232 Heteromi ................ I9 Hippocampus nova-hollandia .. G. 
Page.

Tippocrepis, Monacanthus 222, 265 hippos, Seriola ......... I 49, 264 hippurus, Coryphena... I 173,264 IIistiophoride ......... 21, I69 11istiopterus labiosts ..... 1 22, 263 IIistioptcrus recurvirostris 122,263 Hoplognathide ......... 20, I09 Horned Box-Fish .......... 224 Horse-Mackerel .... I6 16364 11 yperlophus spratellides ..... 27 II ypros subnigrum .......... 233 Hvpoplectredes annulatus .... 262 Hypoplectrodes nigrorubrum I5, 262 Hytoplectrodes semicinctus ... 262 hystrix, Diodon .......... 227

\section{I.}

imperialis, Luvarus ......... IT I indicus, Notorhynchus ...... 232 ind zcus, Tetrapturus ........ I70 inerme, Anema ........... 206 insolens, Schizochirus ....... 207 intermedius, llemirhamphus 64. $26 \mathrm{I}$ irideus, Salmo ............ 33 itaiara, Promicrops ..... 96, 262

\section{J.}

Jackass-Fish .......... I I 9, 263 jacksonensis, Truihypterus .... 217 jacksoniensis, Gnathypops ...... Io8 jaculator, Toxotes .................... 95 Japanese Butterfly-Fish ...... 39 javus, Siganus ........... I 39 Jewfish .............. II 3, 262 Jewfish Family ............ I 13 Joey .................... 210, 211 John Dory, Australian ... I 75, 264 John Dory Family ......... I 74

\section{K.}

$K$ athetostoma lar'e ......... 206 Kelpfish ............ i 8,263 King-Fish ........ I 49, I 51, 26.4 King-of-the-Herrings ....... 2 I 7 Knife-jaw, Australian ....... rog Knife-jawed lishes ........ I 09 Knight-Fishes ............ 89 Knight-Fish, Australian ..... S9 Kosciusko Minnow .......... 50 Krefftius adspersus ......... $\mathrm{I}_{5}$ Kreftius australis .......... I $8_{4}$ Kunlia teniura ............ 9 kumu, Chelidonichthys 16, 200, 265 Kunu Gurnard ............ 200 Kyphosida ............ 20, 9I Kyphosus sydneyanus ... 91, 262 labiatus, Leptocephalus ....... 44 labiosus, Histiopterus .... I22, 263 Labride ............... 21, I $4 \mathbf{1}$ Lactophrys concatenatus ..... 224 lacunosi, Atherina ........ 7 I lave, $h^{\prime}$ athetostoma .......... 206 lavigatus. Platycephalus 197, 264 larigatus, Tetroiton ........ 226 lalandi, Seriola ....... 149, 264 Lamma glamca ............. 233 Lamprey, Wide-mouthed .... 240 Janpreys ............... 239 Lamprey, Short-headed ..... 240 Lancet-1 ish ............. 56

I.ancet-Fishes $\ldots \ldots \ldots \ldots \ldots . \ldots 55$

i.ancelets ............... 240 Larye-scaled Bull's-eye ....... 9o Large-toothed Flounder ... 178,264 Lates calcarifer ......... 96, $26 \mathbf{I}$ Latredide ............. 21, I IS Latris ciliaris ............. I IS Latris hecatcia ........ I 8,263 Leafy Sea-Horses .......... 62 Leatherjacket, Orange-spotted

222,265

Leatherjackets ........... 220

Leatherjacket, Iellow 222, 223, 205 lcichharati, Scleropages .... 25, $26 \mathbf{1}$ Lemon Sole ........... 178, 264 Lenticular Box-1 ish ........ 224 lenticularis, Aracana ....... 224 Lepidoblennius geminatus ..... 210 lepidoptera. Cosioperca ..... 262 Lepidopus caudatus ......... 167 Leptocephalus Labiatus ....... 44 Leptoscopida ............ 21, 204 Leptoscopoid Jishes ........ 204 Leptoscopus macropygus ..... 204 leptosomus, Decapterus ....... 264 Lethrinus chry'sostomus .... I 25,263 Leuciscus rutilus ........... 39 lewtni, Dinolestes ...... 96, 262 Limnichthys fasciaius ....... 207 lineolatus, Coris.... 10, 142, 263 Ling ............. \$6, 262 Jinked Box-Fish .......... 224

Little Bellows-Fish ....... 59 Iittle Rock-Whiting .... 147, 264 Little Saw-Shark ....... 233, 236

Little Shore-Eels ........... 43 Loboies surinamensis ..... 94, $26 \mathbf{1}$ Lobotide .............. 20, 94 Longfin ................ 262 Longfin, Bastard ........ 262 Long-finned Eel ....... 44, 261 L.ong-finned Pike .... 96, 1 o6, 262 longimanus, Caprodon ....... 262 longipes, Bathypterois ....... 55 longispinis, Platycephalus .... 265 
Pigr.

Long-snouted Flounder . . 183,264 Long-spined Flathead 197, I0 8,265 Long Sucling-Fish ......... 10 Jong-Toms .............. o4 Long-Tom, Slender ..... 64,261 Long-Tom, Stout ... 64, 65, 261 loplodon, Aflodactylus .. 119, 263 Zophonecter gallus ......... 183 Totella callarias ........ S6, 262 Lung-Fish, Australian ..... 220 Lung-Fishes ........... 228 Tur'sride ............ $21,1-1$ Luvarus.Fish ........... 17 Luturus imperialis .......... $\$$

\section{II}

Mackerel ............ 162, 26 Mackerel, Barred Spanish .... 204 Mackerel Family .......... 160 Mackerel, Horse .... 162, 163, 264 Mackere1-Scad ............ 264 Mackerel, Spanish ..... 162, 165 Mackerel, Spotted Spanish .... 264 macleayana, Solea .......... $\mathrm{I}_{3}$ macleayana, Tylosurus ... 64, 261 macleavi, Cristiceps ........ 210 Marquaria australasica ... 96, 96, 262 macquariensis, Oligorus ... 96, 262 Macquarie's Perch ... 96, 99, 262 macracanthus, Piacanthus .... 262 11 acrizs amissus ........... 204 macrochir, Polynemus ......... S2 macrolepis, Pempheris ....... 90 macropterus, Daciylosparus 119, 263 maciopygus, Leftoscopus ...... 204 Macruride ............ 20, $8_{5}$ Macrurus australis .......... $8_{5}$ maculata, Sillagn.... 15, 109, 262 Mado ............... 133, 134 Halacopterygii ............ I9

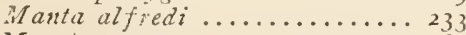
Maori ...........142, 143, 263 marana, Prototroctes ..... 51, 261 Marbled Morwong .......... I 18 marmoratus, Chironemus ... I18, 263 murmoratus, Gadopsis .... 210,265 .Marsipobranchii .......... 239 maximus. Cetorhinus ...... 233 Megalops cyprinoides .... 23, $26 \mathrm{I}$ megastomus, Cnidoglanis ..... 39 melanocercus, ('ypsilurus .. 64, 70 melanopus, Amphiprion ........ I4I microlepidotus, Prionurus ..... 139 milesii, Ap!oactis .......... 191 Minnow, Kosciusto ........ 50 Minnow, Mlountain .......... $5^{\circ}$ Minnows, Australian ........ 49 Minnow, Sydney ........... 50 Minnow, Tasmanian ..... 50, $5^{1}$
Honacunthus ayrandi 221, 222, 265 Jlonacanthus guntheri ........ 2.23 .11onacanthus hippocrefis .. 222, 2015 Monacanthus trossulus ....... 221 Hola mola ............... 228 Molzda ................ 22, 227 Monkfish ............... 233 IIonocentrider .......... 20, So Monocentris sloria-muris ..... So so Manoductylus argentius ...... 133 monopus, Fhombosolca .... 1-S., 264 Mon-Fish .............. 203 Mordacia mordux .......... 240 moriax, Hordacia .......... 240 Morwong ............. 119, 26)3 Mlorwong, Dusky ......... 263 Morwong Family ......... I19 Morwong, Red .......... II0, 263 Morwong, Marbled .......... 118 Nottled Dragonet .......... 200 Mottled Star-gazer ......... $2 n 6$ Mountain Minnow .......... 50 Mud-skipper .......... 1 84, I 86 ilugil dobula .... I5, 74, 259, 261 Mugilida $\ldots \ldots \ldots \ldots \ldots \ldots . .20,73$ Alugzl peronii ........ 15,74, 261 Mugil petordi ............ 20r Musil waigiensis ....... 74, 261 Mullet, Diamond-scaled 74,79, 261 Muliet Fanily ........... 73 Mullet, Flat-tail .. I5. 74, 78,26 I Mullet, Richmond .......... 26r Mullet, Sand .......... 74. 79 Mullet, Sea . 15, 74, 75, 259. 201 Mullet, Silver .............261 Iullets, Red ............. 1 30 Muliet, Vellow-eye $15,74,70,261$ Mullida $\ldots \ldots \ldots \ldots \ldots \ldots .21,130$ multifasciaius, Ephippus . 135, 263 Muranesox cinereus .......... 44 Murknida ............ I(), 43 Murray Cod ......... 96, 99, 262 11 viobatis australis ........ 233 .11 yxus clongatus ..... 74, 75. 261

N.

Sannygai ............ 87, 262 Nannygai liamily .......... 87 Narcine ................. 237 narinari, Aëtobatis ......... 233 Narrow-banded Sole ......... 183 Naseus unicornis .......... 137 nasus, Typhlonus ......... 215 Naucrates ductor ........ 149, 20.4 naucrates, Echencis .......... 191 nebuiosa, Echidna .......... 44 nebulosus, Siganus ......... 139 Neoieratodus forsteri ....... 229 neopilchardus, Clupanodon . 27, 26I 
New Zealand Grayling Page.

New Zealand Whitebait ...... 53

niger, Alepocephalus ......... 36

nigra, Synaptura ....... 178, 264 nigricans, Cheilodactylus .... 263 vigromarginatus. Pseudolabrus 263 nigrorubrum, II ypoplectrodes I 5, 262 Nomeus gronovii ........... 85 Notacanthidre ........... 19, 56 Notacanthoid Fishes ........ 56 Notucanthus sexspinis ........ 56 Notesthes robusta ........ 191, 264 Notorhynchus indicus ........ 232 Nototheniida ........... 22, 205 Notothenioid Fishes ..........205 nove-cambrice, Paralichthys 178, 264 nove-hollandia, Hippocampus .. 6I nove-hollandia, Potamalosa 27, $26 \mathrm{r}$ nove-hollandia, Sphyrana 82, $26 \mathrm{r}$ Numb-Fish ........... 233, 237 nummifer, Antennarius ....... 219 Nummy ................ 237

\section{O.}

Oar-Fish ...............2 217 Odax balteatus ......... I 47,264 Odax richardsonii ......... I42, 263 Odontaspis taurus .......... 233 ogilbyi, Chimara .......... 233 Old-Wife ......... 96, г 55, 262 Oligorus macquariensis .... 96, 262 Olisthops cyanomelas ..... $\mathbf{1 4}_{42}, 264$ ommopterus, Chrorops ........ 263 Ophrdiide ............. 22, 215 Ophisurus serpens ........... 44 Orange-spotted Leatherjacket

222,265

Orectolobus barbatus ........ 232

Ostariophysi ............. 19

Osteoglosside ............ 19, 25

Osteoglossids ............. 25

Ostracion cornutum .......... 224

Ostraciontida .......... 22, 224 ovatum, Xystama ....... 117, 263 Ox-eye $\ldots \ldots \ldots \ldots \ldots .23,26 \mathrm{r}$ oxyrhynchus, Prototroctes ..... 5 I Oyster Blenny .......... 2IO, 2 II

\section{P.}

Pagrosomus auratus .. 15, 125, 263 Painted Eel .............. 44 panauratus, Glyptauchen ...... I9I Paralichthys arsius ...... 178, 264 Paraichthys nova-cambrice 178,264 Parrot Fish, Crimson-banded 263 Parrot-Fishes ............ 14 Parrot Fish, White-spotted 16, 263 Patacus fronto ............. 2 ro paroninus, Achirus ...... I 83,264

Peacock Sole .......... 183,264 Pearl Perch ......... 96, 104, 262 Pediculati ................. 22 Pegasida .................20, 62 Pegasus draconis ............... $6_{3}$ pelamis, Gymnosarda ..... $16_{2}, 264$ Pempherida ............ 20, 90 Pempheris compressus ......... 90 Pempheris macrolepis ......... 9a Pennant-Fish ............ 149, 158 Percalates colonorum .. 15, 96, 262 Percalates fluviatilis . . 96, 97, 262 Percesoces ................ 20 P'erch, Dusky ......... 94, 262 Perch, Estuary ...... 15, 96, 262 l'erch Family ............. 96 Perch, Freshwater ... 96, 97, 262 Perch, Giant ....... 96, 104, 262 Perch, Golden ....... 96, 97, 262 Perch, Macquarie's .. 96, 99, 262 Perch, Pearl ...... 96, 104, 262 Perch, Silver ..... I 22, 123,263 Perch, Trumpeter ...... 122, 263 Perch, Yellow-mouthed .. 125, 129 percoides, Sebastapistes .. 191, 264 percula, Amphiprion ......... 140 Periophthalmus australis ...... I $8_{4}$ peronii, Mugil ....... I5, 74, $26 \overline{\mathrm{I}}$ petardi, Mugil ............ 261 Petromyzontes ............. 239 Petromyzontida ............ 239 Petroscirtes anolis .......... 2 10 philippi, Ileterodontus ....... $23^{2}$ Phyllopteryx foliatus ........ 62 Physiculus bachus ....... 86,262 picta, Gymnothorax ......... 44 Pigfish ............... I4 ${ }^{2}$ l'igfish, Banded ....... 143, 263 Pigfish, Spotted ....... 143, 263 like liamily ............. 82 l'ike. Long-finned … 90, Iov, 262 l'ike, Short-finned ....... S2, 26 r Pike, Skipjack ........... ro Pilchard ........... 27, 261 Pilot-Fish ........ I 49, 157, 264 Pipe-Fishes .............. 59 Pisces .................. 17 Platycephatide ..........2 2 , 196 Platycephalus bassensis ...... 265 Platycephalus cirronasus ..... 107 Platycephalus fuscus 16, 197, 264 Platycephalus levigatus.. 197, 264 Platycephalus longispinis 197, 265 Plecrognathi ............. 22 Plectroplites ambiguus .... 95, 262 Pleuronectida .......... 21, 177 Pointer, Blue ........... 233 Pointer, White .......... 233 
P'Stik. Polynemide ............ 20, 80 Polynemus macrochir ........8 82 Polinnemus sheridani ......... 8r Polynemus tetradactylus .. 8I, 262 polyommata, Pterygotrigia 200, 265 Pomacentrida .......... 21, 139 Pomacentrids ............ I 39 Pomadasis hasta........ I22, $2 \mathrm{~b}_{3}$ Pomatomus saltatrix $\ldots . . \quad 149,264$ Pomfret ............... 174 Pomfrets ............. 174 porosus, Upeneus ....... I 31 , 263 Porcupine-Fish $\ldots \ldots \ldots \ldots \ldots .226$ Porcupines, Sea, .......... 226 Port Jackson Shark .... 232, 233 Port Jackson Shark, Crested .. 232 Portuguese-M an-o'-War Fish .. 85 Potamalosa nova-hollandia 27,261 prasina, Gymnothorax ....... 44 Priacanthus macraianthus ..... 262 Prince Alfred's Ray ..... 233, 238 Prionace glauca ............ 232 Prionurus microlepidotus ..... ${ }_{13} 8$ Pristiophorus cirratus ....... 233 Pristipomatida ......... 21, 122 Pristis zysron ........... 233 Promicrops itaiara ...... 96, 262 Prototroctes marana ...... 51, 262 Prototroctes oxyrhynchus ...... 5 I Psettodes crumei ....... I78, 264 Pseudaphritis urvillii ... 205, 265 Pseudochromidida ........ 20, 108 l'seudochrcmids ........... 108 Pseudolabrus gymnogenis .. I6, 263 Pseudolabrus nigromarginatus 263 Pseudomugil signifer ........ $7^{\mathrm{I}}$ Pterygotrigla polyommata 200, 265 Ptercis volituns ........... I9I pugnax, Betta ............. 39 punilata, Drepane ........ 263 punctata, Sillago ........ 109, 262 punitulatus, Dicotylichthy's ... 226 f'urpie-striped Gudgeon ...... 185 purpurasiens, Gobioides ...... 184 purpurissatus, Aulopus 15, 53, $26 \mathrm{r}$

\section{().}

quadrilineutus, Terapon .. I 22, 263 Queen-Fish ............... 264 Queensland Groper .. 96, 103, 262 Queensland 11alibut I78, I81, 264 Queensland' 'Trumpeter I22, I 23,263

l.

Racizecentrida .......... $2 \mathrm{I}, \mathbf{1} 59$ Rachycentron canadus .... 159, 264 Raia ................. 233 raii, Brami............ 174
Page.

Rainbow Trout ............ 33

Rainbow-Fish ........16, I42, 263 rayneri, Galeocerdo ........ 232 Rays ................. 231 recurvirostris, Histiopterus 1 22, 263 Red Bull's-Eye ........... 262 Red Breanı ............. 126 Red $\operatorname{Cod} \ldots \ldots \ldots \ldots .86,87,262$ Red Fire-Fish ........ 191, 195 Red Gurnard ....... I6, 200, 265 Red Gurnet-Perch ...... 19I, 264 Red Groper .............. 263 Red-Indian Fish ....... 210, 212 Red Morwong ........ 119, 263 Red Mullets ............. I 30 Red Rock-Cod .... 191, 193, 264 Regalecus glesne ........... 217 regularis, Ilemirhamphus 64, $25926 \mathrm{I}$ reinhardtii, Anguilla ... 43, $26 \mathrm{I}$ Remora remora ............ I9I Retropinna retropinna ........ $3^{2}$ Rhinobatus banksii ......... 233 Rhombosolea monopus .... I 178,264 Ribbon-Fishes ............ 216 Ribbon-Fish, Southern ..... 216 richardsonii, Odax ...... $14^{2}, 26_{3}$ Richardson's Boar-l*ish .. I22, 124 Richmond Mullet .......... 26r Rifle-Fish ............... 95 Rifle-Fishes .............. 95 River Blackfish ........ 210, 265 River Garfish ... 64, b7, 259, 201 River Shark ............ 232 Roach ................. 39 robusta, Notesthes ....... r9r, 264 Rocí-Cod, Black .... 96, 103, 262 Rock-Cod, Red .... 191, 193, 264 Rock Flathead ..... 197, 198, 264 Rockling, Australian ........ 215 Rock Whiting ...... I42, I45, 263 rostrata, Ammotretis ..... 183,264 Roughy ............... 89 Roughy (of South Australia)

I 7,262

rufus, Cheilobranchus ........ 43 rutilus, Leuciscus .......... 39

5.

Salmo fario ................. $3^{6}$

Salmo irideus ............. 33

Salmon .......... II 3, I16, 262

Salmon. Beaked .......... 37

Salmon, Cooktown .......8 81, 262

Salmon Catfishes ........ 40, 4I

Salmon Family ............. $3^{2}$

Salnon-Herring $\ldots \ldots \ldots$ 27, 3I, 26r

Salinonida ............ 19, $3^{2}$

Salmon-Trcut ............ r Í́ 
Pagie.

saltatrix, P'omatomus ..... 149, 20.4 Salzelinus fontinalis ........ $3^{6}$ Samson-Fish ...... I 49, I 53, 204

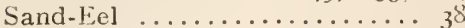
Sand Mullet ..... 74, 79, 261 Sand Whiting .. 15, 109, 259, 262 Sandy ............................ 205 Sandy Sprat .......... 27, 30 sarba, Chrysophrys ..... 125, 26.3 Sarda chilensis ......... 162, 204 Sariinella castclnami ..... 27, $26_{1}$ saurus, Elops ......... 23, 201 Sawfish ........... 233, 236 Saw-Shark, Little ...... 233, 236 Scabbard-Fish .......... 167, 168 scapulare, Glaucosoma .... 96, 262 Scaride ............. 2I, I4I Schizochirus insolens .......207 School Whiting ........... I I I Scicina antarctica ....... 113, 262 Scianide ............ 20, 113 sclerolepis, Arrhamphus .. 04, 261 Scleropages leichhardti .... 25, 26 I scolopax, Centriscus ......... 59 Scomber colias ......... 162, 264 Scomberoides sancli-petri ...... 204 Scomberomorus commersonii 162,264 Scomberomorus guttatus ... I02, 264 Scombresocide ........... 20, 64 Scombresox forsteri .........64 64 Scombrida ............. 21, 160 Scopelide ............ 19, 53 Scopeloids .............. 53 Scorpanida ........... 21, 191 Scorpænoici Fishes ......... IgI Scorpena cruenta ....... I9I, 264 Scorpidida ............ 21, 133 Scorpis aquipinnis ...... 133, 263 scriba, Galaxias ............ 50 Sea-Carp ......... I 19, 1 20, 203 Sea-Dragon, Australian ...... 63 Sea-Dragons ............. 62 Sea Crarfish ........ 64, 60, 261 Sea-Hedgehog .......... 227 Sea-Horse, Common ........ 6 Sea-Horses .............. 59 Sea.Horses, Leafy ........ 62 Sea Mullet ... I 5, 74, 75, 259, 261 Sea-l'erch, Banded ........ 262 Sea-Perch, Black-spotted .... 262 Sea-Perch, Cuvier's ..... I 5, 262 Sea-Perch, Half-bancied ..... 202 Sea-Porcupines ......... 226 Sea-Robins ............. 202 Sea-Snipe ............... 59 Sea-Snipes .......................... $55^{\circ}$ seba, Genyoroge ........... 262 Scbastapistes percoides .... I I I, $20_{4}$ semicinctus, Hypoplectrodes .... 262

sephen Dasyatis ......... I'AGE.

Sephen Stingray .................. 233

Sergeant Baker ............. . . 53,233

Sergeant-Fish ......... 159, 264

Tergeant-Fishes ........... I 59

Seriola hippos ......... I 49, 264 Seriola lalandi ......... 149, 264 Serivlella brama ........... 84 serpens, Ophisurus ......... 44 Serpent Eel ........... 44, 48 Serranide ............ 20, 96 serratus, Acanthistius ..... 96, 262 setifer, Xiphasia .......... 210 Seven-gilled Shark ..... 232, 233 sexsfinis, Notacanthus ....... 5ó Shark, Angel ........... 233 Shark, Basking ....... 233, 235 Shark, Blue ........................ 232 Shark, Carpet ........... 232 Shark, Crested l'ort Jackson .. 232 Shark, Fox .......... 232, 235 shark, Ghost ............ 233 Shark, Hammer-headed ..... 232 Thark, Port Jackson .... 232, 233 Shark, River ........... 232 Sharks ............. $23^{1}$ Shark, Seven-gilled ..... 232, 233 Slark, Tiger ........ 232, 235 Sharp-beaked Gurnard 200, 201, 265 sheridani, Polynemus ......... SI Shore-Eel, Banded ......... 43 Ghore-Eels, Little ......... 43 Short-beaked Garfish .. 64, 68, 261 hhort-finned Eel ........... 44 Short-finned Pike ........ \$2, 261 short-headed Lamprey ..... 240 Short Sucking-lish ........ 191 Shovelnose ............. 233 Siganida ............. 21, $13^{8}$ Siganus jarius ............ I 39 Siganus nebulosus ....... 139, 263 signatus, $L^{7}$ penews .......... 1 $3^{1}$ signifer, Psendomugil ...... 71 Sillaginid. .......... 20, 109 Sillago bassensis .......... 111 Sillago cilinta .. 15, 109, 259, 262 Sillago maculata .... 15, 109, 262 Sillago punctata ....... I09, 262 ¿ilurida ............. 19, 39 Silverbellies ............ 1 i 7 Silverbelly ........... 117,263 Silver Dory ........... I 76,264 silver Eel ........... 44, 48 Silver Muilci ............ 261 Silver Perch ....... 1 22, 1 23, 263

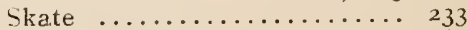
Skipjack l'ike ........ 107, 262 Skipper Ciarfisl $\ldots \ldots \ldots$ 15,64,70 Skulpins .............. 208 
P'AGE.

Slender Long-Tom ....... 64, 26 I Slippery ..............2 210,265 Small-scaled Bull's-eye ...... 9o Smail-toothed Flounder i 78 , I 79 ,

264

Smelt, Australian ......... 32

Snapper .......... 15, 125, 263

Solea macleayana ........... I 83

Sole, Black ....... I78, I8 1264

Sole, Lemon ........ 1 78,264

Sole, Narrow-banded ....... i $8_{3}$

sole, Peacock ......... 18 8,264

Sc]dier-Fish ......... 96, 107

Southern Flounder .. 178, 181, 264

Southern Ribbon-Fish ....... 216

Spanish Mackerels ...... 162, 165

Spanish Mackerel, Barred .... 264

Spanish Mackerel, Spotted ... 264

Sparide ............... 21, 125

Spearfishes ............. 169 Sphyrana nova-hollandia $S_{2}, \quad 261$

Spinyranida ........... 20, 82

Sphyma zygana ........... $23^{2}$ spinarella, Cephalacanthus 202, 265

Spotted Butter-Fish .... 137, 263

Spotted Eagle-Ray ........ 233

Spotted Goatfish .......... I $3^{1}$

Spotted Pigfish ............. $26_{3}$

Spotted Spanish Mackerel ... 264

Spotted Whiting .... I09, I12, 262 spratellides, Hyperlophus ..... 27 Sprat, Sandy ............27, 30

Square-tail, Cuvier's ........ 84

Squatina squatina ........... 233

Star-gazer ............. 205

Star-gazer, Mottled ......... 206

Stirgray, Black ........... 233

Stingray, Common ..... 233, 237

Stingray, Sephen .......... 233

Stingray, Thorn-tailed .. 233, 238

Stink-Fish ............. 208

Stomiatide .............. I9, 37

Stomiatoid Fishes ......... 37

Stone-lifter ...........206, 20 -

Stout Long-Tom ..... 64, 65, 201 striatus, Antennarizes ........ 218 strigatus, Atypichthys ....... 133 strigatus, Chatodon ......... I 35

Struped Angler-Fish ......... 218

Striped Chætodon ...... 1 35,136

Striped Gudgeon ........ I84, 185

Stromateide.............20,84

subnigrum, Hypnos ........ 233

Sucking-Fishes .......... I 89

Sucking-Fish, Long ......... I9I

Sucking-Fish Short ........ I

Sun-Fish, Common ......... 228

Sun-Fishes ............. 227

Surgeon-Fish $\ldots \ldots \ldots \ldots \ldots \ldots \ldots \ldots \ldots \ldots \ldots$

Surgeon-Fishes .......... 137
PAGE

surinamensis, Lobotes ..... 94, 262 Sweep .............. I 33, 263 Sweep Fanily ........... 133

Swordfishes ............. 169 sydneyanus, $K$ yphosus ... 91, 262 Sydney Minnow ............ so Symbranchide .......... 19, 43 Syinbranchii .............. 19 Symphurus unicolor ...... 178, 264 Synaptura nigra ....... I 78,264 Syngnathide ............ 20, 59

T.

taniura, Kiuhlia ............91

Taiter .......... I 49, I 53, 264 tandanus, Copidoglanis .. 40, 26I Tarwhine ........ 125, 129, 263 Tasmanian Minnow ....... 50, 51 Tasmanian Trumpeter ....118, $26_{3}$ Tassel-Fish, Blind .......... S2 Tassel-Fishes .............. 8o taurus, Odontaspis ......... 233 Teleostei ..........19, 20, 21, 22 Telcostomi ............ 17, 19 Telescope-Fish ............. 39

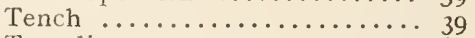
Teraglin ......... 11 $3,115,263$ Terapon ellipticus ....... 122, 263 Terapon quadrilineatus .. 122, 263

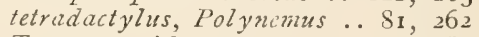
Tetragonuride $\ldots . . \ldots \ldots . .20 . \mathrm{S}_{4}$ Tetragonurus cuvieri ........... $\mathrm{S}_{4}$ Tetrapturus indicus ........ 170 Tetrodon hamiltoni .......... 225 Tetrodon lavigatzis ......... 220 Tetrodontida ............ 22, 225 thalassinus, Galeichthys .... 40, $4^{2}$ thetrdis, Dasyatis .......... 233 Thorn-tailed Stingray .... 233, 238 Threadfins ............... 80 Thresher ............... $23^{2}$ Thunnus thynnus ........... I万I thynnus, Thunnus .......... I6 Thyrsites atun ......... . 660,264 Tinca tinca ............... 39 Tiger Sharks ...........232, 235 Toad-Fishes ............ 225 Toado ................. 225 Tobacco-pipe Fishes ....... 57 Tongue-Fish .......... 1 $7 \dot{\$}$, 182 Toxotes jaculator ............ 95 Toxotida ............. 20, 95 Trachichthys ausiralis ....... S9 Trachinotus baillonii ......... 264 Trachurus declivis ... 10, 149, 264 Traihypterida .......... 22, 216 Trachytterus jucksonensis.... 217 
Pagk. trasula, Upeneus .......... I3I Trevally ...... 16, 149, 152, 264 Trevally, Black ........ 139, 263 Trichiuride ........... 21, 166 Trichiurus coxii ........... 166 Trichonotida ........... 22, 207 Trichonotoid Fishes ........ 207 tricuspidata, Girella 15, 91, 262 Triglida ............. 21, 199 Tripletails ............... 94 True Eels .............. 43 Trout, Brown $\ldots \ldots \ldots \ldots \ldots \ldots 3^{6}$ Trout, Rainbow ........... 33 Trumpeter, Bastard ..... 118, 263 Trumpeter Perch ....... 122, 263 Trumpeter, Queensland 122, 123 ,

Trumpeters ............ 118 Trumpeter, Tasmanian ........ 118 Trumpeter Whiting 15, 109, I I I, 262 Trumpet-Fish ........... 59 truncatus, Chelmonops ........ 135 Trunk-Fishes ............ 224 trutta, Arripis ............ I 3,262 truttaceus, Galaxias ........ 50 Trygonoptera bucculenta ...... 233 Trygonorrhina fasciata ..... 233 Tunny ................. $16 \mathbf{1}$ Tyiosurus ferox ........6. 64, 261 Tylosurus macleayana ... 64, 261 Tyfizlonus nasus ........... 215

U.

unicolor, Symphurus .... I78, 264 Unicorn-Fish ........... 137 unicornis, Naseus .......... 137 unimaculatus, Diastodon .. 142, 203 Upeneus porosus ........ I II, 263 Upeneus signatus .......... I $3 \mathbf{I}$ Upeneus tragula ........... I 3 I Uranoscopida .......... 22, 205 urvillii, Pseudaphritis .. 205, 265

\section{$\mathrm{V}$.}

variabilis, Coryphanoides .... 86 Variegated Flathead .... I97, I9 8 variegatus, Bovichthys ...... 205 Velvet-Fish ........... I9I, 195

PAGE.

volitans, Pterois .......... $19 \mathrm{I}$

vulpes, Alopias ........... $23^{2}$

\section{W.}

waikiensis, Mugil ...... 74, 261 Walking-Fishes ........... 218 Warehou .................. $8_{4}$ Weed-Fish, Crested .... 210, 212 Whaler ............... 232 Whario ................. 84 Whario Family ............ 84

Whiptails .............. 85

Whitebait, New Zealand ..... 33

White Pointer ............... 233

White-spotted Parrot-fish .. I6, 263

Whiting Family ........... Io9

Whiting, Little Rock- .. 1 47, 264

Whiting, Rock- ... 142, 145, 263

Whiting, Sand .. 15, 109, 259, 262

Whiting, School ........... I I I

Whiting, Spotted .. I09, I 1 2, 262 Whiting, Trumpeter 15, Io9,

III, 262

Wirrah Wol,begong ............. 232, 234

Wrasses .............. I4I

\section{$\mathrm{X}$.}

Xiphasia setifer ........... 210 Xystama ovatum ........ 117, 263

$\mathrm{Y}^{\top}$.

Yeliow-belly $\ldots \ldots \ldots \ldots=6.97,262$ Yellow-eye Mullet .... i $5,74,261$ Yeliow Leatherjacket 222, 223, 265 Iellow-mouthed Perch I25,

Yellowtail ........ I6, 129,263

Yellowtarl Family ........... 149

\section{Z.}

Zeide .............. 21, I74 Zeus australis ......... 175, 264 Zourcida .............. 22, 214 Zoarcoid Fishes ........... 214 zygana, Sphyrna .......... 232 zysron, Pristis ............ 233 


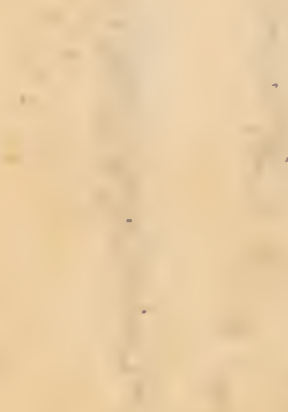

